\title{
MOLECULAR MECHANISMS OF INSULIN RESISTANCE IN GLUCAGON-PRODUCING ALPHA CELLS
}

\author{
Dissertation \\ zur Erlangung des Doktorgrades \\ der Mathematisch-Naturwissenschaftlichen Fakultäten \\ der Georg-August-Universität zu Göttingen
}

vorgelegt von

Miranda González Aguirre

Aus Mexiko Stadt, Mexiko

Göttingen 2006 
D7

Referent:

Prof. Dr. R. Hardeland

Korreferent:

Prof. Dr. D. Doenecke

Tag der mündlichen Prüfung: 02.11.06 
Diese Arbeit wurde in der Abteilung Molekulare Pharmakologie am Zentrum Pharmakologie der Georg-August-Universität Göttingen angefertigt.

Die Untersuchungen wurden durch den Deutschen Akademischen Austausch-Dienst (DAAD) und den Consejo Nacional de Ciencia y Tecnología (Conacyt - Becario No. 124423) unterstützt.

Teile der Arbeit wurden bereits veröffentlicht:

González-Aguirre, M., Böer U., Knepel W. (2006) Effect of hyperglycemia, hyperinsulinemia, oxidative stress and IL-1 $\beta$ on the insulin-induced inhibition of glucagon gene transcription. Abstracts from $47^{\text {th }}$ Spring Meeting. German Association for experimental and clinical Pharmacology and Toxicology, (Mainz, Germany). NaunynSchmiedeberg's Archives of Pharmacology, 372 (1): 71.

González-Aguirre, M., Böer U., Knepel W. (2005) Effect of adipokines on the insulininduced inhibition of glucagon gene transcription, Abstracts from $3^{\text {rd }}$ Annual World Congress on the Insulin Resistance Syndrome (San Francisco, Cal., USA). Diabetes and Vascular Disease Research, 2 (3): 163.

González-Aguirre, M., Böer U., Knepel W. (2005) Molecular mechanisms of insulin resistance, Abstracts from $46^{\text {th }}$ Spring Meeting. German Association for experimental and clinical Pharmacology and Toxicology, (Mainz, Germany). Naunyn-Schmiedeberg's Archives of Pharmacology, 371 (1): R14. 
To carlos, the joy and love in my life 


\section{TABLE OF CONTENTS}

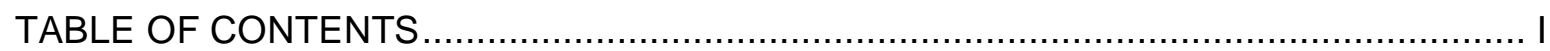

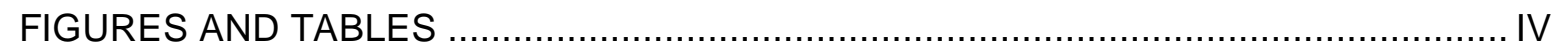

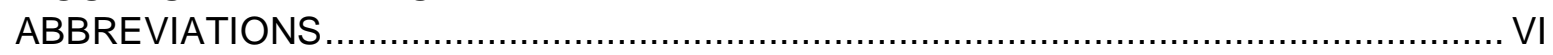

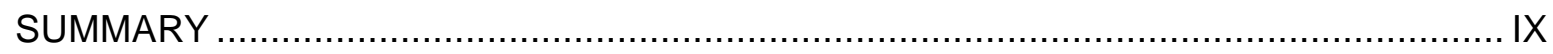

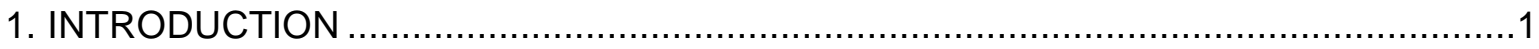

1.1 Insulin and glucagon in the regulation of glucose homeostasis .............................

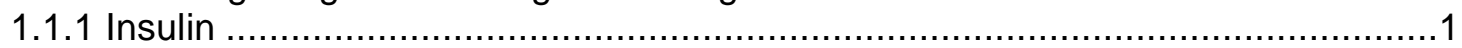

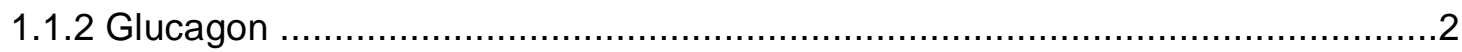

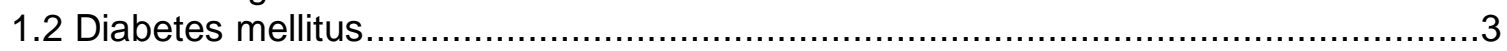

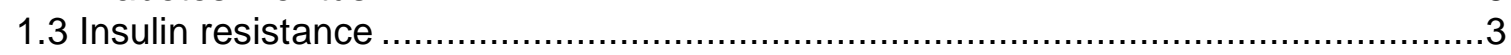

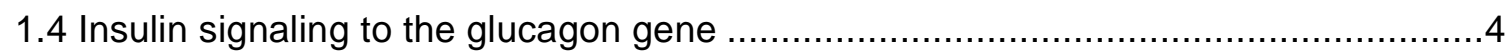

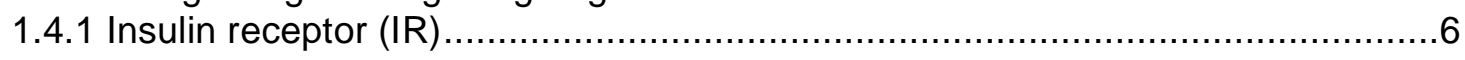

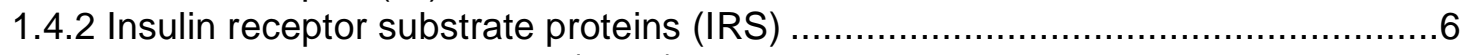

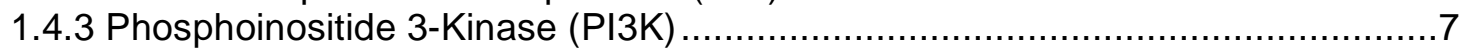

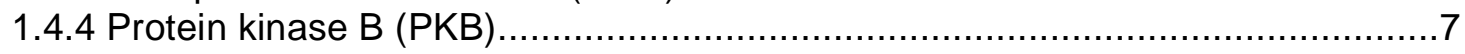

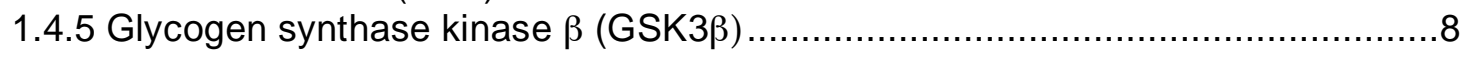

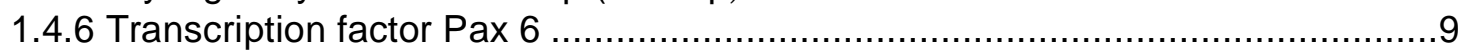

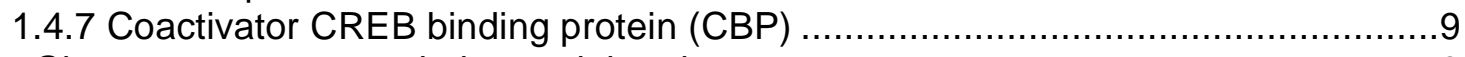

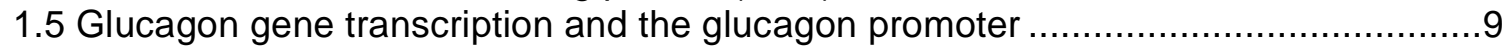

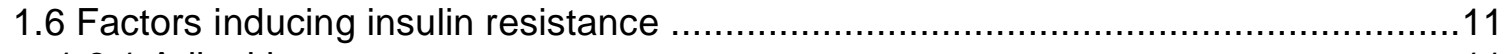

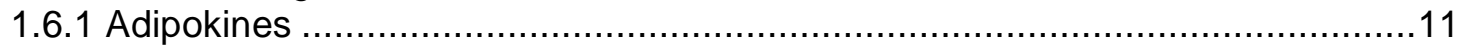

1.6.2 Free fatty acids and other insulin resistance-inducing molecules ....................11

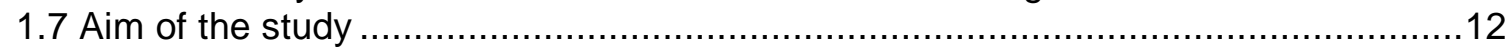

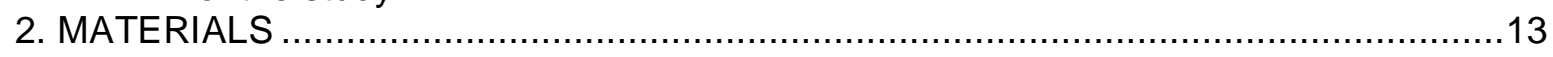

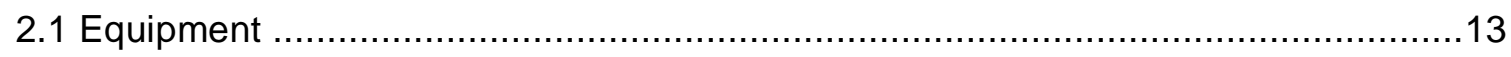

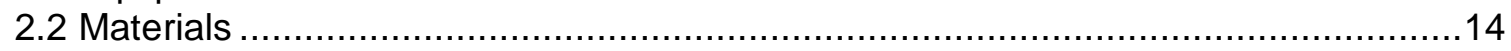

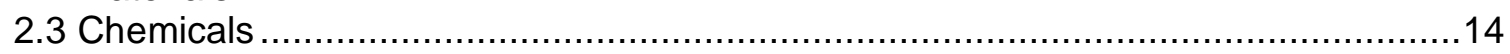

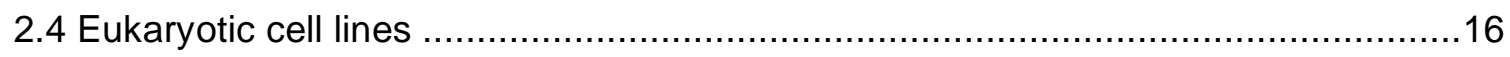

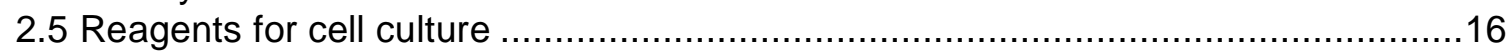

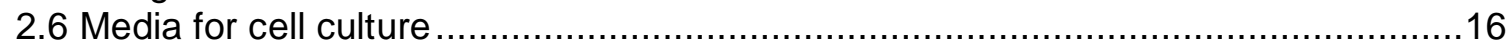

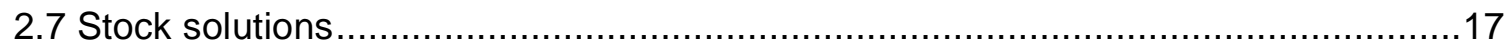

2.8 Reporter gene plasmids and expression plasmids ........................................... 17

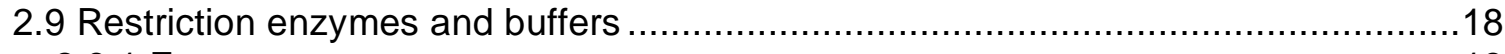

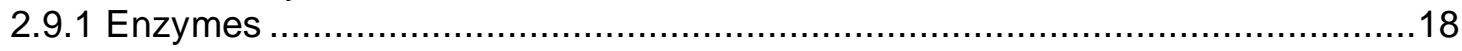

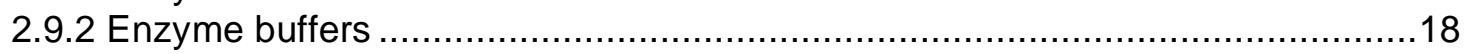

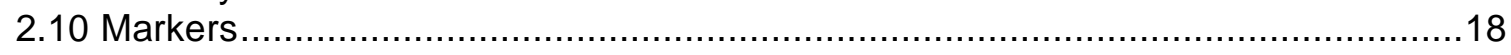

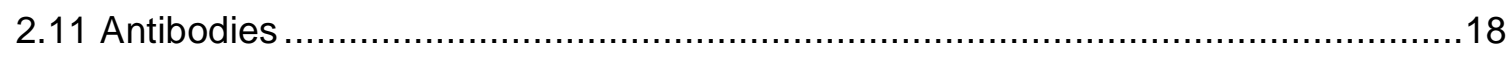

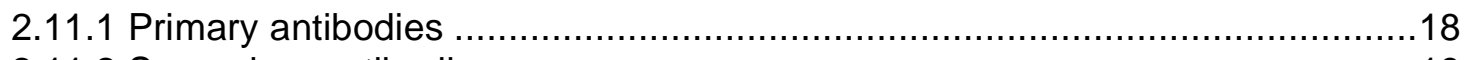

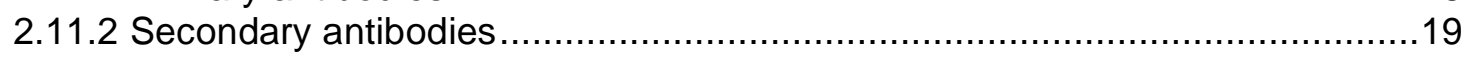

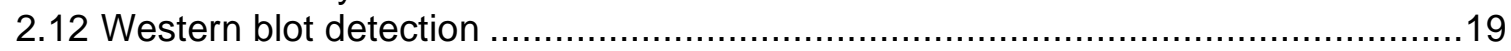

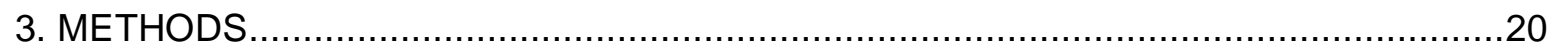

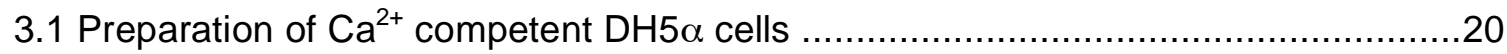

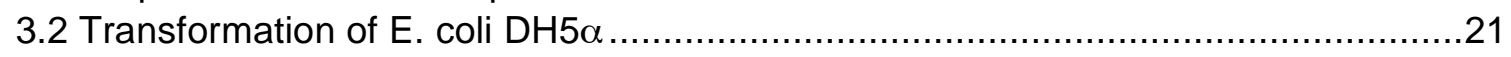

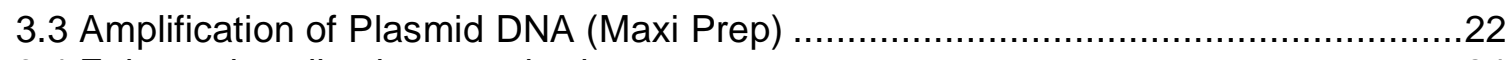

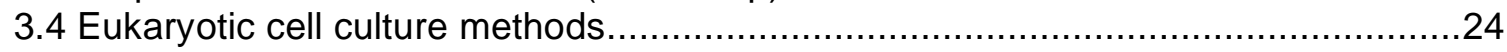

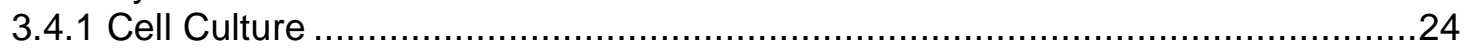

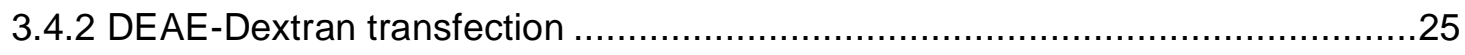

3.5 Cell extract preparation for luciferase and GFP measurements ...........................27

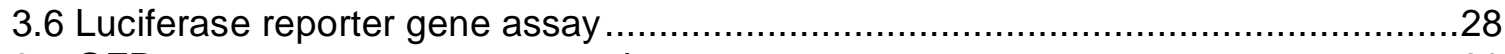

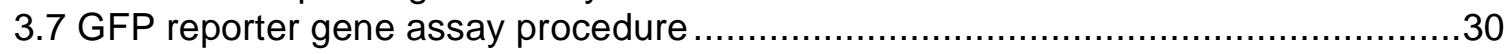




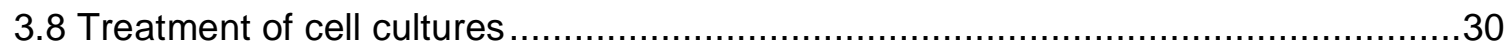

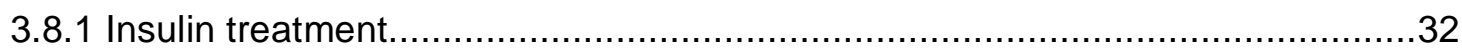

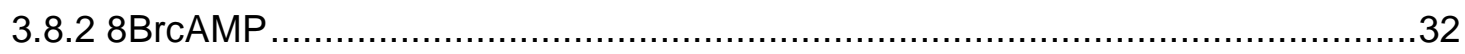

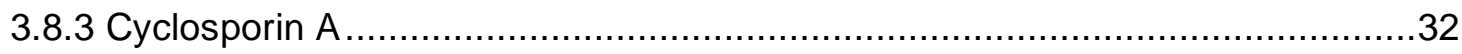

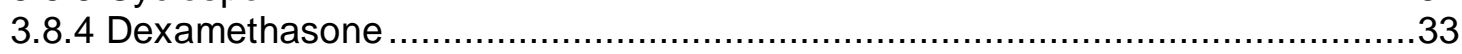

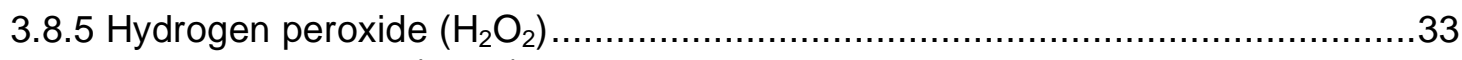

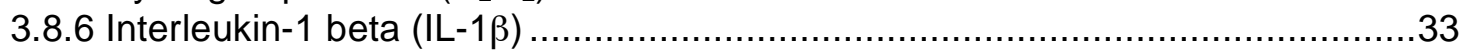

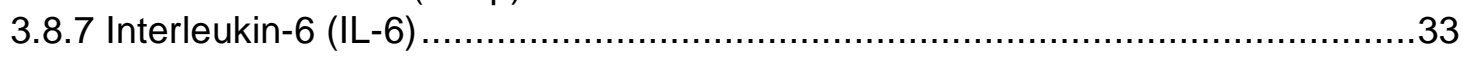

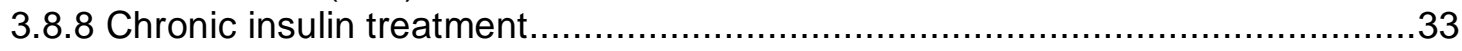

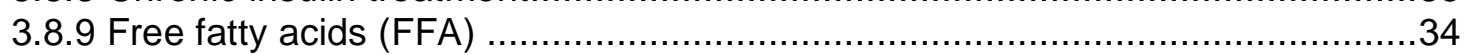

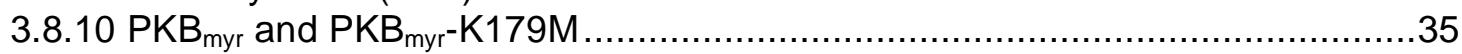

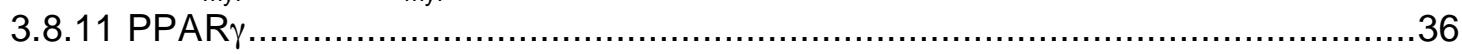

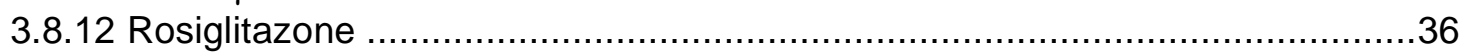

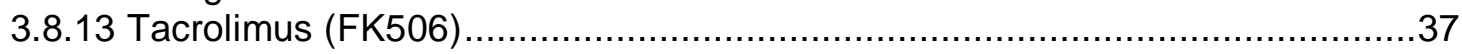

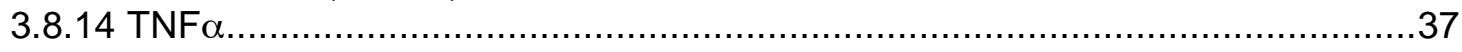

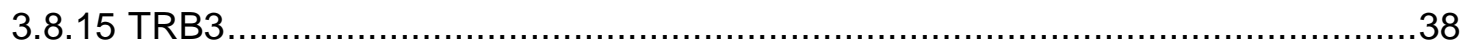

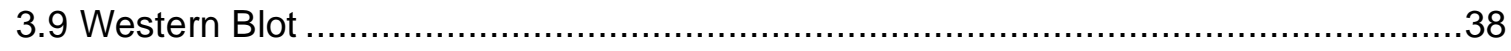

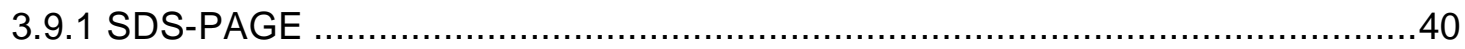

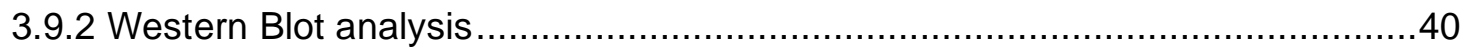

3.9.2.1 Western Blot using semi dry transfer ................................................. 41

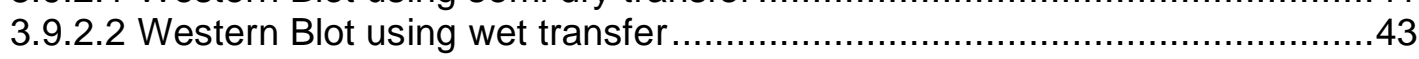

3.9.2.3 Western blot processing and quantification ........................................44

3.10 Treatment of cells for PKB and Phospho Ser 473 PKB analysis ........................44

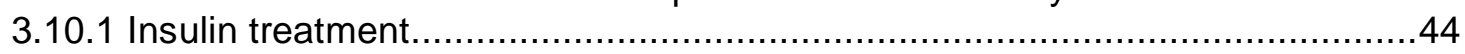

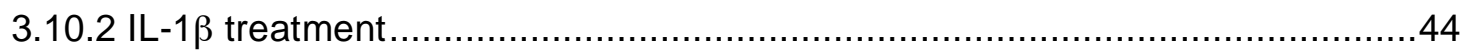

3.10.3 Preparation of cell lysates for PKB analysis ......................................45

3.11 Treatment of cells for IR and Phospho-IR (Tyr 1150 / 1151) analysis...................45

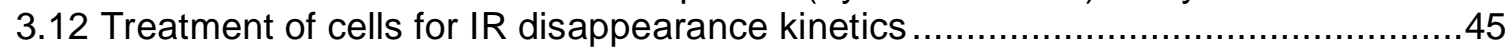

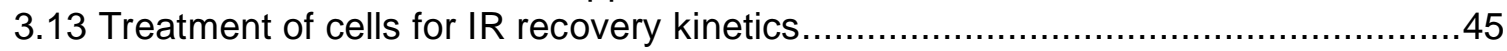

3.14 Treatment of cells for proteasomal inhibitor analysis .....................................46

3.15 Treatment of cells for protein synthesis inhibition analysis ................................46

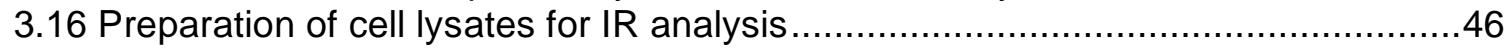

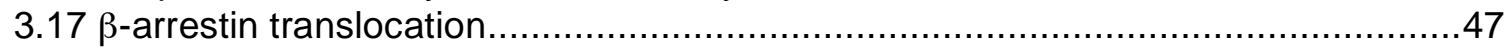

3.18 Treatment of cells for lysosomal degradation inhibitors analysis .........................47

3.19 Treatment of cells for IRS-1 and Phosho-IRS-1 (Tyr 612) analysis ....................48

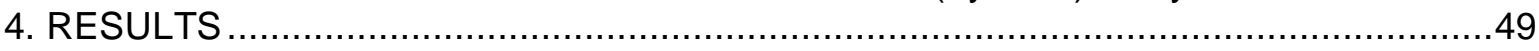

4.1 Effect of substances known to induce insulin resistance in other tissues, on the

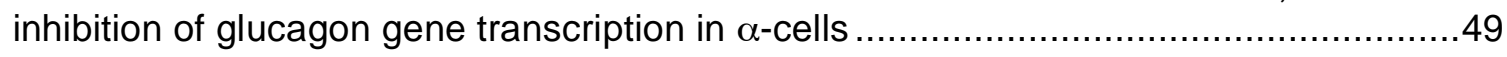

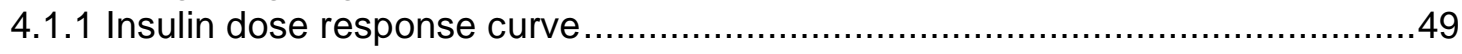

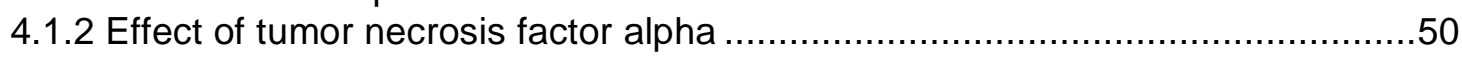

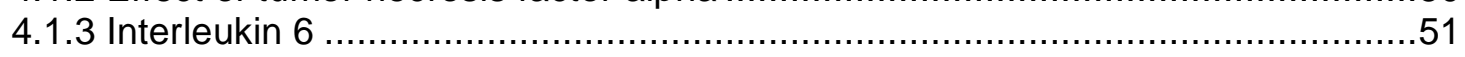

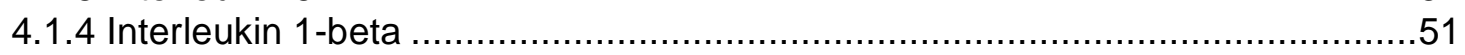

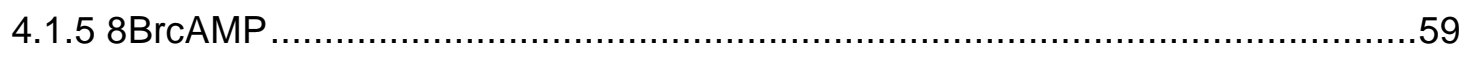

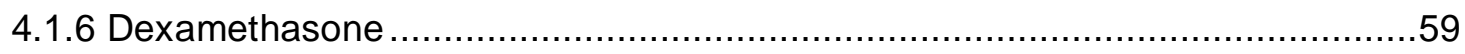

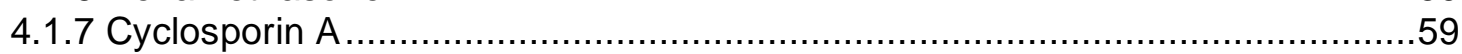

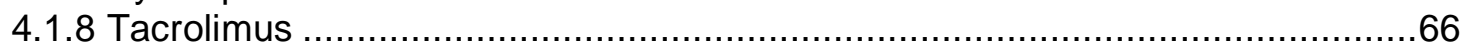

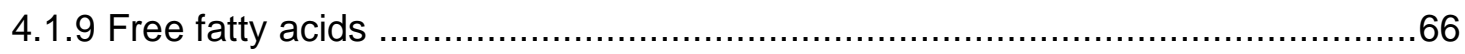

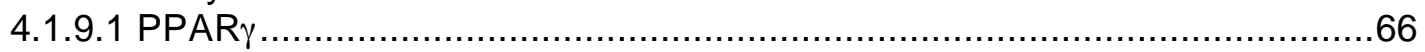

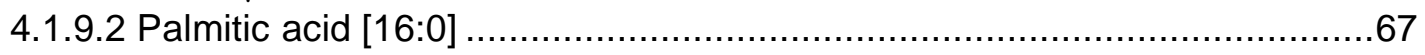

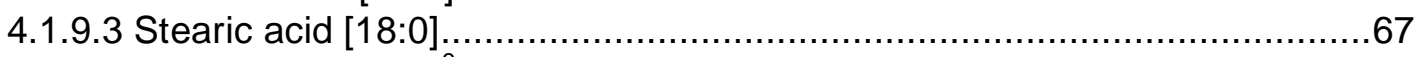

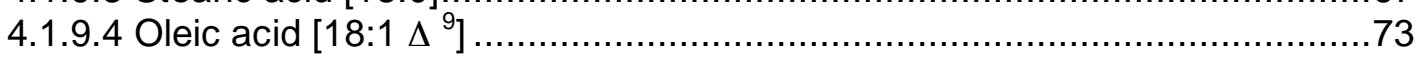




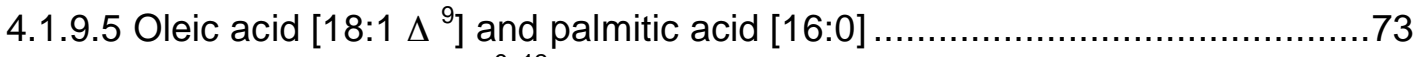

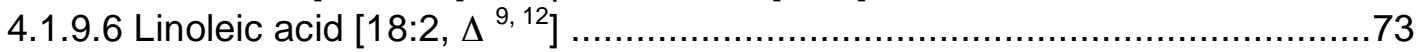

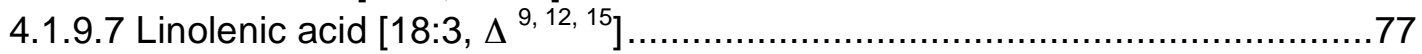

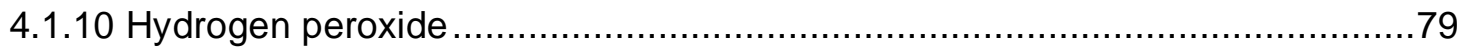

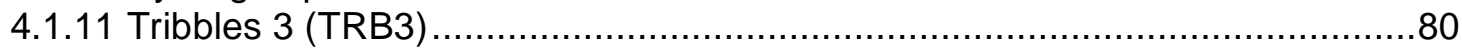

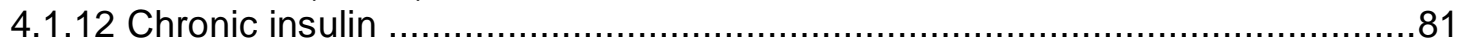

4.1.13 Summary of the effect of substances known to induce insulin resistance in other tissues, on the inhibition of glucagon gene transcription in $\alpha$-cells ...................82

4.2 Further characterization of the effect of TNF $\alpha$ and PPAR $\gamma$ on glucagon gene

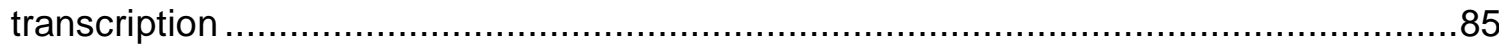

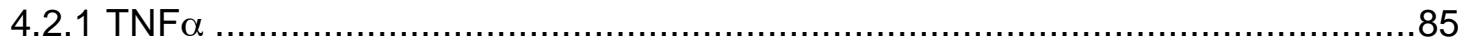

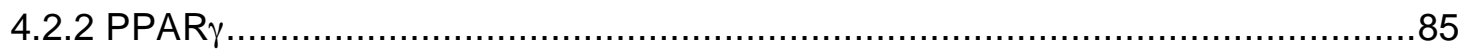

4.3 Further characterization of the blockade by chronic insulin treatment and IL-1 $\beta$ of the insulin-induced inhibition of glucagon gene transcription .............................................

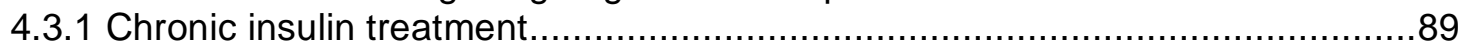

4.3.1.1 PKB phosphorylation, expression and action...................................... 89

4.3.1.2 Expression and autophosphorylation of the insulin receptor ......................92

4.3.1.3 Time course of insulin receptor disappearance ......................................94

4.3.1.4 Insulin receptor recovery after insulin withdrawal...................................99

4.3.1.5 Effect of chronic insulin on insulin receptor expression levels in the presence of protein synthesis inhibitors............................................................99

4.3.1.6 Effect of proteasomal inhibitors on insulin receptor expression levels........99

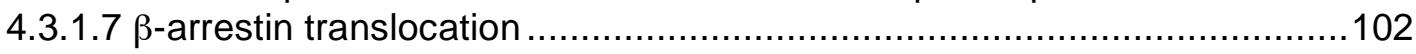

4.3.1.8 Effect of lysosomal inhibitors on insulin receptor expression levels .........103

4.3.1.9 Expression and phosphorylation of the insulin receptor substrate 1 ........105

4.3.2 Interleukin 1-beta ............................................................................... 107

4.3.2.1 Effect of interleukin 1-beta on PKB phosphorylation and expression .......107

4.3.2.2 Effect of interleukin 1-beta on insulin receptor phosphorylation and

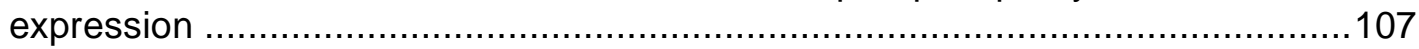

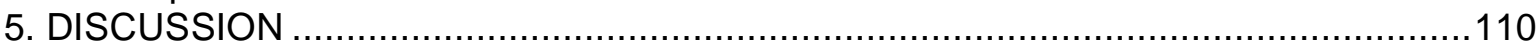

5.1 Substances without an effect on glucagon gene transcription ............................111

5.2 Substances with novel effects on glucagon gene transcription ...........................112

5.3 Substances with known effects on glucagon gene transcription .........................116

5.4 Substances that interfered with the insulin-induced inhibition of glucagon gene

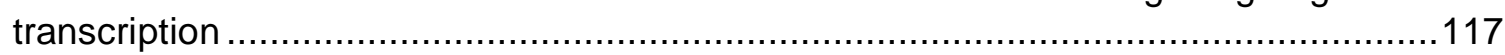

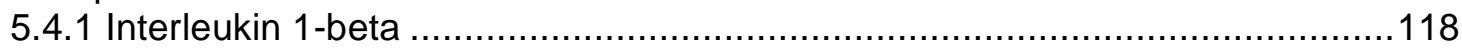

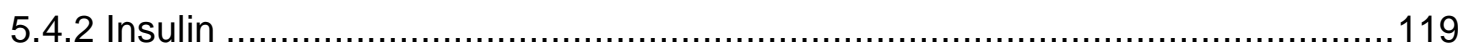

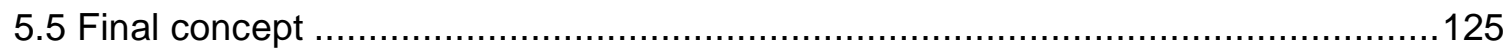

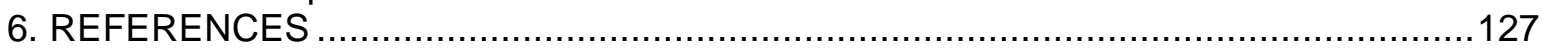




\section{FIGURES AND TABLES}

Fig. 1. Close view of an Islet of Langerhans and magnification of alpha and beta cells

Fig. 2. Signal transduction in insulin action

Fig. 3. Proposed model of insulin signaling to the glucagon gene

Fig. 4. Control cis-elements within the glucagon promoter and their

corresponding transcription factors

Fig. 5. Time line for $\mathrm{PKB}_{\mathrm{myr}}$ and $\mathrm{PKB}_{\mathrm{myr}}-\mathrm{K} 179 \mathrm{M}$ experiments

Fig. 6. Insulin dose-dependently inhibits glucagon gene transcription

Fig. 7. Effect of $24 \mathrm{~h}$ treatment with TNF $\alpha(10 \mathrm{ng} / \mathrm{ml})$ on basal and insulin induced-inhibition of glucagon gene transcription

Fig. 8. Effect of $46 \mathrm{~h}$ treatment with TNF $\alpha(10 \mathrm{ng} / \mathrm{ml})$ on basal and insulin induced-inhibition of glucagon gene transcription

Fig. 9. Effect of $24 \mathrm{~h}$ treatment with TNF $\alpha(100 \mathrm{ng} / \mathrm{ml})$ on basal and insulin induced-inhibition of glucagon gene transcription

Fig. 10. Effect of $24 \mathrm{~h}$ treatment with interleukin $6(20 \mathrm{ng} / \mathrm{ml})$ on basal and insulin induced-inhibition of glucagon gene transcription

Fig. 11. Effect of $46 \mathrm{~h}$ treatment with interleukin $6(20 \mathrm{ng} / \mathrm{ml})$ on basal and

insulin induced-inhibition of glucagon gene transcription

Fig. 12. Effect of $24 \mathrm{~h}$ treatment with interleukin 1-beta $(10 \mathrm{ng} / \mathrm{ml})$ on basal

and insulin induced-inhibition of glucagon gene transcription

Fig. 13. Effect of $24 \mathrm{~h}$ treatment with interleukin 1-beta $(0.02 \mathrm{ng} / \mathrm{ml})$ on basal and insulin induced-inhibition of glucagon gene transcription

Fig. 14. Effect of $24 \mathrm{~h}$ treatment with $8 \operatorname{BrcAMP}(1 \mathrm{mM})$ on basal and insulin induced-inhibition of glucagon gene transcription

Fig. 15. Effect of $46 \mathrm{~h}$ treatment with $8 \operatorname{BrcAMP}(1 \mathrm{mM})$ on basal and insulin induced-inhibition of glucagon gene transcription

Fig. 16. Effect of $24 \mathrm{~h}$ treatment with dexamethasone $(1 \mu \mathrm{M})$ on basal and insulin induced-inhibition of glucagon gene transcription

Fig. 17. Effect of $46 \mathrm{~h}$ treatment with dexamethasone $(1 \mu \mathrm{M})$ on basal and insulin induced-inhibition of glucagon gene transcription

Fig. 18. Effect of $24 \mathrm{~h}$ treatment with cyclosporin $\mathrm{A}(300 \mathrm{nM})$ on basal and insulin induced-inhibition of glucagon gene transcription

Fig. 19. Effect of $46 \mathrm{~h}$ treatment with cyclosporin $A(300 \mathrm{nM})$ on basal and insulin induced-inhibition of glucagon gene transcription

Fig. 20. Effect of $24 \mathrm{~h}$ treatment with tacrolimus $(10 \mathrm{nM})$ on basal and insulin induced-inhibition of glucagon gene transcription

Fig. 21. Effect of $46 \mathrm{~h}$ treatment with tacrolimus $(10 \mathrm{nM})$ on basal and insulin induced-inhibition of glucagon gene transcription

Fig. 22. Effect of PPAR y co-transfection on basal and insulin induced-inhibition of glucagon gene transcription

Fig. 23. Effect of $24 \mathrm{~h}$ treatment with palmitic acid $(0.2 \mathrm{mM})$ on basal and insulin induced-inhibition of glucagon gene transcription

Fig. 24. Effect of $24 \mathrm{~h}$ treatment with stearic acid $(0.2 \mathrm{mM})$ on basal and insulin induced-inhibition of glucagon gene transcription

Fig. 25. Effect of $24 \mathrm{~h}$ treatment with oleic acid $(0.4 \mathrm{mM})$ on basal and insulin induced-inhibition of glucagon gene transcription

Fig. 26. Effect of $24 \mathrm{~h}$ treatment with oleic acid $(0.2 \mathrm{mM})$ and palmitic acid $(0.2$ $\mathrm{mM}$ ) on basal and insulin induced-inhibition of glucagon gene transcription 
Fig. 27. Effect of $24 \mathrm{~h}$ treatment with linoleic acid $(0.4 \mathrm{mM})$ on basal and insulin induced-inhibition of glucagon gene transcription

Fig. 28. Effect of $24 \mathrm{~h}$ treatment with linolenic acid $(0.4 \mathrm{mM})$ on basal and

insulin induced-inhibition of glucagon gene transcription

Fig. 29. Effect of $24 \mathrm{~h}$ treatment with hydrogen peroxide on basal and insulin induced-inhibition of glucagon gene transcription

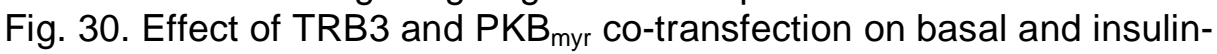
induced inhibition of glucagon gene transcription

Fig. 31. Effect of a chronic insulin treatment on glucagon gene transcription

Fig. 32. Effect of TNF $\alpha$ treatment on stimulated glucagon gene transcription

Fig. 33. Effect of PPAR $\gamma$ co-transfection and $46 \mathrm{~h}$ treatment with rosiglitazone on basal and insulin-mediated inhibition of glucagon gene transcription

Fig. 34. Effect of PPAR $\gamma$ co-transfection and $120 \mathrm{~h}$ treatment with rosiglitazone on basal and insulin-mediated inhibition of glucagon gene transcription

Fig. 35. Effect of PKB on glucagon gene transcription with or without a $23 \mathrm{~h}$ or $46 \mathrm{~h}$ insulin treatment

Fig. 36. Effect of an extended insulin exposure on PKB Ser 473phosphorylation and PKB expression

Fig. 37. Effect of an extended insulin exposure on insulin receptor

autophosphorylation (on Tyr 1150 / 1151) and expression

Fig. 38. Kinetics for insulin receptor autophosphorylation and expression

Fig. 39. Timeline for recovery of the insulin receptor

Fig. 40. Recovery kinetics for the insulin receptor

Fig. 41. Effect of insulin withdrawal followed by a recovery period on glucagon gene transcription

Fig. 42. Effect of insulin treatment on insulin receptor expression in the presence of cycloheximide

Fig. 43. Effect of proteasomal inhibitors on insulin receptor expression levels

Fig. 44. Effect of insulin treatment on $\beta$-arrestin expression and translocation from the cytoplasm to the cell membrane in InR1G9 cells

Fig. 45. Effect of lysosomal inhibitors on insulin receptor expression levels

Fig. 46. Effect of an extended insulin exposure on insulin receptor substrate 1 phosphorylation on Tyr 612 and expression

Fig. 47. Effect of interleukin 1-beta treatment on PKB phosphorylation and expression

Fig. 48. Effect of interleukin 1-beta treatment on insulin receptor phosphorylation and expression

Fig. 49. Chronic insulin treatment interferes with the insulin-induced inhibition of glucagon gene transcription in pancreatic islet $\alpha$-cells (hypothesis)

Table 1. Effect of different treatments on basal glucagon gene transcription 
ABBREVIATIONS

Akt

amp

ANOVA

APS

ATP

bp

BSA

CAMP

CBP

CDNA

CMV

${ }^{\circ} \mathrm{C}$

CRE

CREB

CsA

$\mathrm{CsCl}$

DEAE

DMSO

DNA

DTT

EDTA

FBS

FFA

Fig.

FK506

$\mathrm{g}$

Gab-1

GAPDH

GFP

Grb2

GS

GSK-3 $\beta$

h

HAT

HRP

$\mathrm{IC}_{50}$

IDDM

IGFR

IL-1 $\beta$

IL-6

IR

IRS

JAKs

$\mathrm{KB}$

$\mathrm{KCl}$

$\mathrm{kDa}$

L

LAM protein kinase $B$

ampicillin

analysis of variance

ammonium persulfate

adenosine triphosphate

base pairs

bovine serum albumin

cyclic adenosine-3’, 5`-monophosphate

CREB binding protein

copy deoxyribonucleic acid

cytomegalovirus

centigrade

cAMP response element

cAMP response element-binding protein

cyclosporin A

cesium chloride

diethylaminoethyl

dimethylsulfoxide

deoxyribonucleic acid

dithiothreitol

ethylendiamine-tetra-acetic-acid

fetal bovine serum

free fatty acids

figure

tacrolimus

gram (s)

Grb2-associated binder-1

glyceraldehyde-3-phosphate

dehydrogenase

green fluorescent protein

guanine nucleotide exchange factor

glycogen synthase

glycogen synthase kinase 3 beta

hour (h)

histone acetyltransferase

horseradish peroxidase

$50 \%$ inhibitory concentration

insulin-dependent diabetes mellitus

insulin-like growth factor receptor

interleukin 1-beta

interleukin 6

insulin receptor

insulin receptor substrate (s)

janus kinases

kilobase (s)

potassium chloride

kilodaltons

liter (s)

luciferase assay mix 


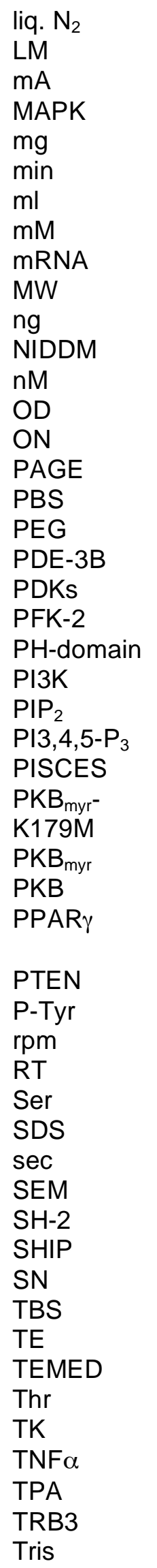

liquid nitrogen

luciferase mix

milliampers

mitogen-activated protein kinase

milligram

minute (s)

milliliters

millimolar

messenger ribonucleic acid

molecular weight

nanogram (s)

non-insulin-dependent diabetes mellitus

nanomolar

optical density

overnight

polyacrylamide gel electrophoresis

phosphate-buffered saline

polyethylenglycol

phosphodiesterase-3B

phosphoinositide-dependent kinases

phosphofructokinase-2

pleckstrin homology domain

phosphatidylinositol-3-OH-kinase

phosphatidyl inositol-4-5-biphosphate

phosphatidyl inositol-3-4-5-triphosphate

pancreatic islet cell enhancer sequence

myristylated mutant protein kinase $B$

myristylated protein kinase $B$

protein kinase $B$

peroxisome proliferator-activated-

receptor $\gamma$

phosphatase and tensin homolog

phosphotyrosine (s)

revolutions per minute

room temperature

serine

sodium-dodecyl-sulfate

second (s)

standard error of the mean

Src homology-2

$\mathrm{SH} 2$-containing inositide phosphatase

supernatant

tris-buffered saline

tris-EDTA

N`N`N`N'-tetramethyldiamine

threonine

tyrosine kinase

tumor necrosis factor alpha

phorbol 12-myristate 13-acetate

tribbles 3

tris-(hydroxymethyl)-aminomethane 
Tween 20

Tyr

TZD

$\mathrm{v} / \mathrm{v}$

$w / v$

$\mu l$

$\mu g$ polyoxyethylen-sorbit-monolaurate

tyrosine (s)

thiazolidinediones

volume / volume

weight / volume

microliters

micrograms 


\section{SUMMARY}

Type II diabetes mellitus is a chronic disease, affecting more than 150 million people worldwide. Type II diabetes mellitus is characterized by insulin resistance of peripheral tissues (liver, muscle and fat), $\beta$-cell dysfunction, as well as by the elevation in the concentration of glucagon in plasma. Considering that insulin inhibits glucagon secretion and gene transcription, the hyperglucagonemia and hyperinsulinemia in type II diabetes mellitus suggests that there is insulin resistance also in the glucagon-producing pancreatic $\alpha$-cells. Hyperglucagonemia contributes to hepatic glucose production and to elevated glucose levels in type II diabetes mellitus. However, the molecular mechanisms of insulin resistance at pancreatic islet $\alpha$-cells are unknown. In the present work the effect of molecules, implicated in conferring insulin resistance in some other tissues, was investigated on the regulation of glucagon gene transcription by insulin at the level of the pancreatic islet $\alpha$-cell. Insulin inhibition of glucagon gene transcription in the glucagonproducing $\alpha$-cell InR1G9 provided a suitable model for this study. The results of this work indicate that elevated levels of insulin or the proinflammatory cytokine interleukin 1-beta are able to reverse the insulin-induced inhibition of glucagon gene transcription. Functional studies with a constitutively active form of protein kinase $B$ showed that protein kinase $B$ still inhibited glucagon gene transcription after a chronic insulin treatment; together with a markedly reduced phosphorylation of $\mathrm{PKB}$, this demonstrates that targets upstream of PKB within the insulin signaling pathway are affected by chronic insulin treatment. Indeed, it was found that chronic insulin treatment blocked insulin signaling at the level of the activation of the insulin receptor and at the level of the insulin receptor substrate 1. After chronic insulin treatment, the activity and expression of the insulin receptor and of the insulin receptor substrate 1 were reduced. Downregulation of the receptor was found to be a reversible, time-dependent process. In addition, further results suggested that the downregulation was due to an enhanced degradation. Degradation of the insulin receptor was neither mediated through proteasomal nor $\beta$-arrestin-associated degradation mechanisms. Instead, insulin receptor downregulation appears to be mediated through lysosomal degradation. Taken together the results of the present study suggest that elevated insulin and interleukin 1-beta levels lead to the development of an insulin resistant state at the level of the pancreatic islet $\alpha$-cells in type II diabetes mellitus. 


\section{INTRODUCTION}

\subsection{Insulin and glucagon in the regulation of glucose homeostasis}

Glucose homeostasis is achieved when the concentration of glucose in the blood is maintained within narrow limits (Buchanan, 1976; Woods et al., 2006). This equilibrium involves regulation of hepatic glucose production and glucose utilization by the liver, muscle and adipose tissue. The pancreatic hormones responsible to look after this balance are insulin and glucagon. In diabetes mellitus, hyperglycemia (high glucose concentrations) results from multiple defects in insulin action and glucose sensing. Insulin action on glucose uptake in muscle, glucose production by the liver and kidneys, and lipolysis in adipose tissue is impaired, while the ability of glucose to stimulate insulin secretion, inhibit hepatic glucose production and promote its own uptake is diminished (DeFronzo, 1997; Mevorach et al., 1998).

\subsubsection{Insulin}

Insulin is produced by the $\beta$-cells of the islets of Langerhans in the pancreas. Its secretion is determined by the change in the concentration of plasma glucose that occurs in response to fasting or feeding. During fasting, insulin secretion by pancreatic $\beta$-cells is low. In order to maintain normoglycemia (normal glucose levels), the liver releases glucose to the blood, matching its utilization by glucose dependent tissues and by the brain. Upon a meal, high levels of glucose induce the secretion of insulin. Glucose is then transferred from the blood into the muscle, fat and liver (DeFronzo, 1988). The increased insulin secretion also reduces the mobilization of fuel stores and stimulates the uptake of carbohydrates, lipids and amino acids by sensitive tissues (muscle, liver and adipose tissue). In addition to increasing glucose uptake into skeletal muscle and adipose tissue, insulin promotes the synthesis of high-energy storage macromolecules like glycogen (in muscle and liver) and lipids (in fat and liver). At the same time, insulin inhibits the breakdown of these storage macromolecules through glycogenolysis and lipolysis, respectively (Kumar and O'Rahily, 2005). 


\subsubsection{Glucagon}

Contrary to the physiological function of insulin, glucagon is involved in the increase of glucose concentration in the body (Fanelli et al., 2006). Glucagon, a 29 amino acid peptide hormone, promotes carbohydrate and lipid catabolism by stimulating glycogenolysis, gluconeogenesis and ketogenesis in target tissues as the liver, which is the major target tissue of this hormone (Balks and Jungermann, 1984). Glucagon is mainly produced by $\alpha$ cells of the pancreatic islets (Ravazzola and Orci, 1979), but its precursor (proglucagon) is also found in few neurons in the brain, in the intestine (Jiang and Zhang, 2003) and thymus (Drucker, 1998) as well as in stomach cells of human fetuses (Ravazzola et al., 1981). The secretion of this hormone is determined by local factors like somatostatin and by systemic factors. The principal systemic factor that regulates the secretion of glucagon is the glucose concentration in plasma. Glucagon release is thus stimulated by hypoglycemia and is inhibited by hyperglycemia (Gerich, 1981). Additionally, glucagon secretion is also stimulated by amino acids released by digestion of a meal rich in protein. To achieve a proper regulation of glucagon secretion, a paracrine control mechanism exists between $\alpha$-cells and $\beta$-cells. In response to higher levels of glucose, $\beta$-cells produce and secrete insulin, this hormone acts on $\alpha$-cells downregulating the secretion of glucagon and inhibiting its transcription (Grzeskowiak et al., 2000; Philippe, 1989). When glucose levels decrease, insulin is not longer secreted allowing the secretion and transcription of glucagon, leading to hyperglucagonemia. In the pancreatic islets, $\beta$-cells are located in the center of the islets of Langerhans surrounded by $\alpha$-cells. This histological distribution promotes the control by the paracrine mechanism (Figure 1).
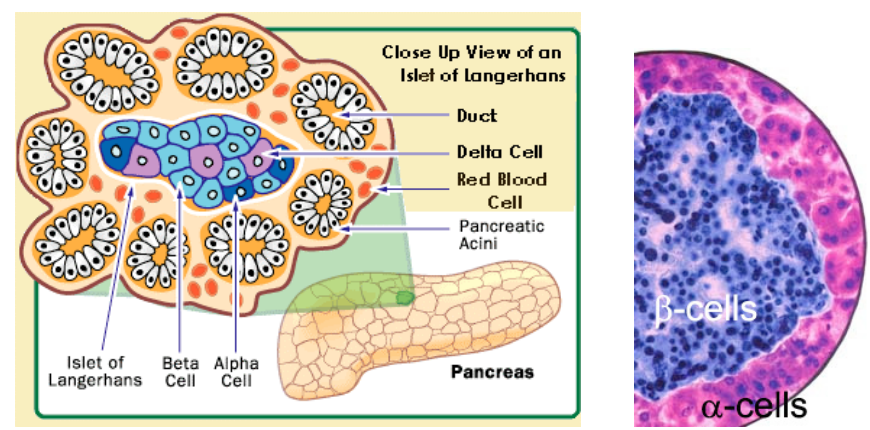

Figure 1. Close view of an Islet of Langerhans and magnification of alpha and beta cells. The left panel shows a schematic representation of the Islets of Langerhans in the pancreas. The right panel shows the histological distribution of alpha and beta cells in an islet (www.rajeun.net / diabetes-pancreas.gif). 


\subsection{Diabetes mellitus}

The balance between the secretion and activity of insulin and glucagon allows the maintenance of glucose homeostasis. Disorders in this homeostasis are associated with severe metabolic diseases in humans. Among these diseases, diabetes mellitus is the most common with the number of cases worldwide estimated at 150 millions in 2003 (Diamond, 2003). The hallmark of diabetes is an elevated blood glucose concentration, but it is also characterized by other biochemical and physiological alterations. There are two types of diabetes mellitus: type I diabetes mellitus or insulin-dependent diabetes (IDDM), and type II diabetes mellitus or non-insulin dependent diabetes mellitus (NIDDM) (Diamond, 2003). Type I diabetes mellitus is caused by an immune-mediated selective destruction of the insulin producing $\beta$-cells within the endocrine pancreas. In type II diabetes mellitus, $\beta$-cells are present but they do not regulate properly the secretion of insulin in response to augmented glucose in plasma. In addition to the altered insulin secretion, peripheral tissues present insensitivity to the action of this hormone. This condition is known as insulin resistance. Thus, type II diabetes patients present $\beta$-cell dysfunction, insulin resistance, as well as elevated glucagon levels in plasma (hyperglucagonemia) (Boron and Boulpaep, 2004; Reach and Assan, 1979).

\subsection{Insulin resistance}

Insulin resistance is a syndrome characterized by a diminished ability of insulin to perform its normal physiological functions (i.e. the regulation of glucose metabolism) (Zick, 2004). Insulin resistance develops when insulin target organs including muscle, liver and adipose tissue are not able to sense appropriately the insulin produced by the $\beta$-cell. This condition results in an increase in the production of insulin by the $\beta$-cell (hyperinsulinemia). Additionally, high concentrations of glucose (hyperglycemia) as well as high concentrations of glucagon (hyperglucagonemia) are also present during insulin resistant states (Lebovitz and Feinglos, 1980). Although some pathophysiological and physiological knowledge about insulin resistance has been gained in recent years, many aspects of the molecular mechanisms and the influence of other substances in the generation of this syndrome need to be addressed. Some studies have attempted to explain insulin resistance as a result of a defective or altered insulin signaling (Capeau, 2005; Chakraborty, 2006; Musi and Goodyear, 2006). However, a high tissue-specific 
heterogeneity and the possibility of cross talk between insulin and other signaling cascades (Kumar and O'Rahily, 2005), have complicated the interpretation of the data.

\subsection{Insulin signaling to the glucagon gene}

Besides glucose homeostasis, insulin regulates diverse physiological processes including membrane transport, intermediary metabolism, cell growth and differentiation (Czech, 1977). These last two processes seem to be mediated by the regulation of gene transcription exerted by insulin. Among other target genes, it has been previously shown that insulin inhibits the transcription of the glucagon gene (Grzeskowiak et al., 2000) as well as the secretion of this hormone (Philippe, 1991). Over the last 20 years, some advances have been made in the understanding of the insulin pathways by which insulin influences diverse cellular targets (Saltiel and Kahn, 2001) (Figure 2). Nevertheless, the exact mechanisms involved in this complex regulation are still unknown. Thus, in order to understand the regulation of glucagon gene transcription by insulin, further studies of the signaling pathway to the glucagon promoter have to be performed.

Previous work using the pancreatic islet $\alpha$-cell line InR1G9 (Grzeskowiak et al., 2000; Schinner et al., 2005a), has contributed to the understanding of the insulin-signaling pathway to the glucagon gene in this cell line (Figure 3). Insulin, upon binding to the insulin receptor (IR), activates the phosphoinositide-3'-kinase (PI3K) / protein kinase $B(P K B)$ pathway. The IR possess a tyrosine kinase activity that catalyses its autophosphorylation, as well as the phosphorylation of diverse sites on multiple intracellular substrates such as the insulin receptor substrate proteins: IRS-1 and IRS-2. Even when IRS proteins do not have a catalytic activity, their phosphorylation creates binding sites for adapter proteins and enzymes like PI3K that propagate the signal. PI3K and the phosphoinositidedependent kinases 1 and 2 (PDK1 and PDK2) activate PKB, which then phosphorylates glycogen synthase kinase 3 beta (GSK3 $\beta$ ). The phosphorylation of GSK3 $\beta$ inhibits its activity, resulting in the disruption of the nucleoprotein complex on the glucagon promoter. Some of the main components of this complex are the transcription factor Pax 6 and its coactivator CREB binding protein (CBP) (Grzeskowiak et al., 2000; Schinner et al., 2005a). 


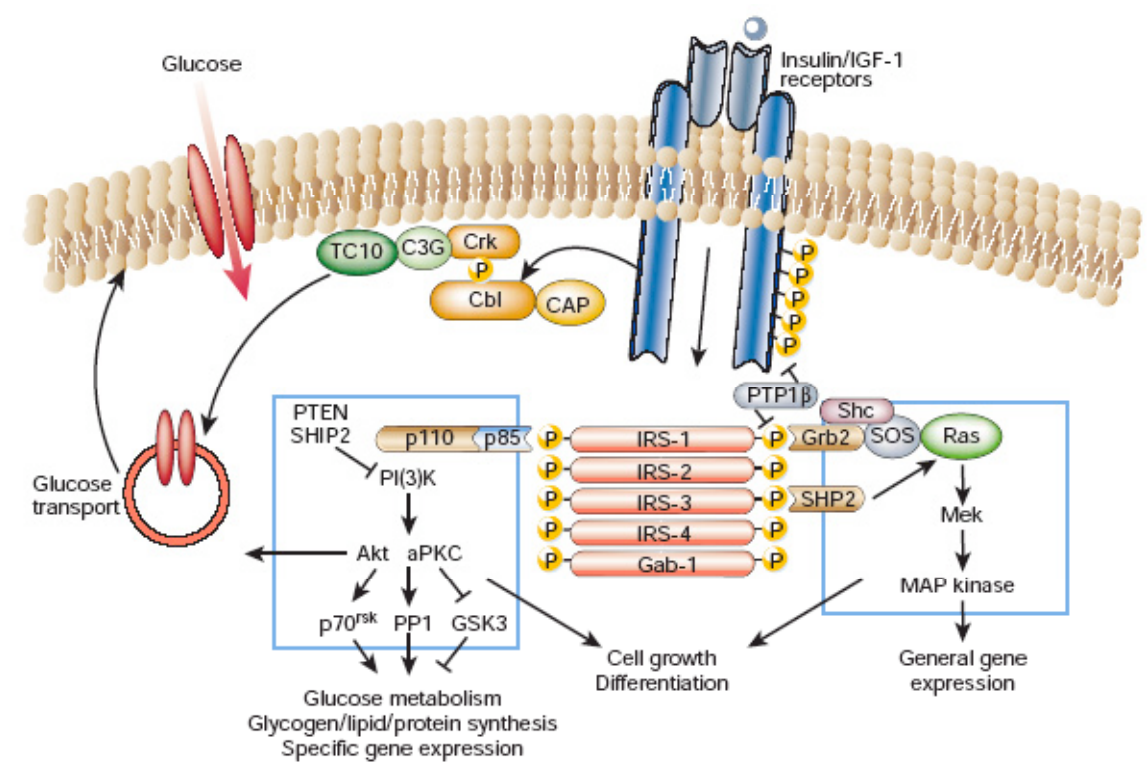

Figure 2. Signal transduction in insulin action (Saltiel and Kahn, 2001). Insulin upon binding to its receptor activates the tyrosine kinase activity of the insulin receptor. This activity phosphorylates downstream members of the insulin receptor substrate family (IRS), Shc and Cbl. These molecules interact with proteins resulting in signaling through diverse pathways: PI3K pathway, MAPK pathway and the glucose transport mediated by the glucose transporter GLUT4 translocation. Insulin action thus regulates general and specific gene expression, cell growth and differentiation, glucose metabolism and protein synthesis.

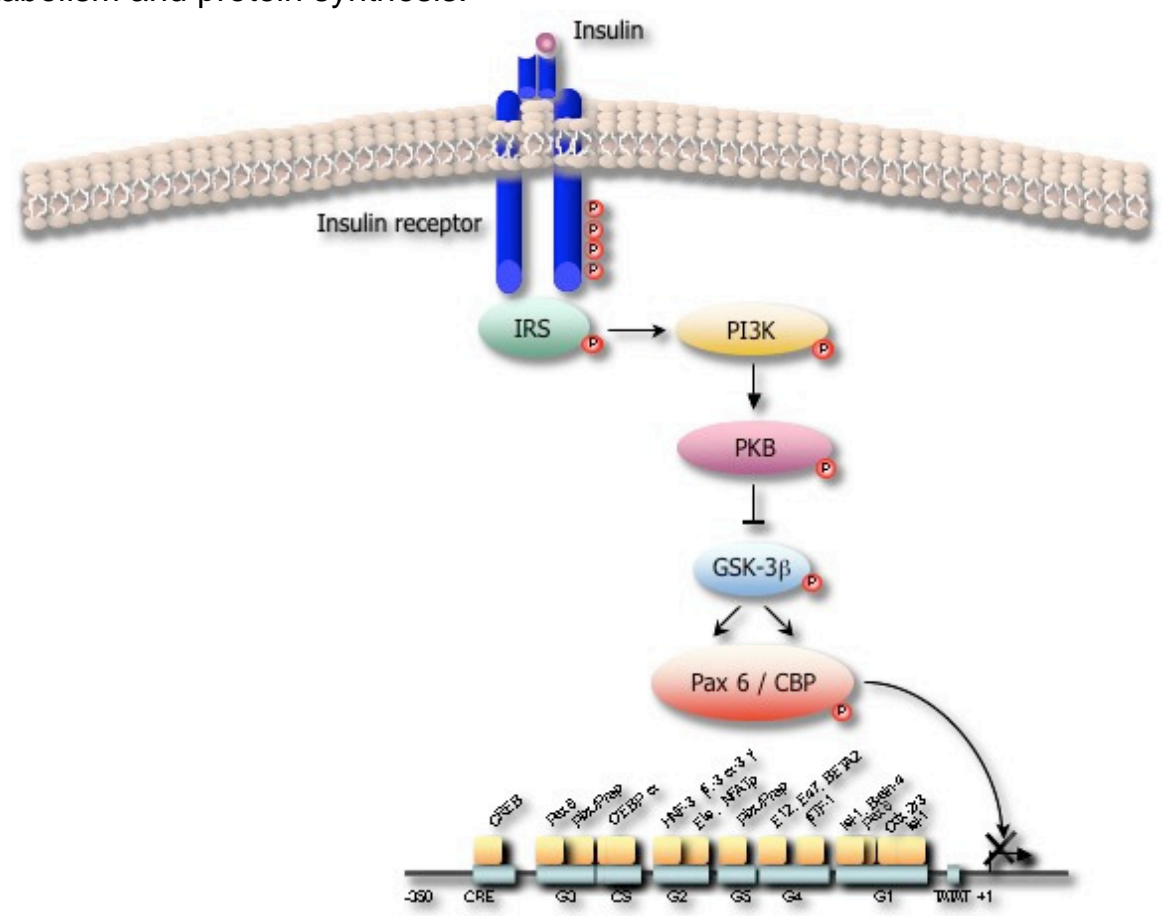

Figure 3. Proposed model of insulin signaling to the glucagon gene (Grzeskowiak et al., 2000; Schinner et al., 2005a). Glucagon gene expression is controlled by insulin at the transcriptional level through the phosphoinositide-3'-kinase (PI3K) / protein kinase B (PKB) pathway. PKB phosphorylates glycogen synthase kinase 3 beta (GSK3 $\beta$ ) and inactivates this kinase. The downstream transcription factors Pax 6 and its coactivator CREB binding protein (CBP) interact with DNA elements within the glucagon promoter. This insulin signaling pathway confers inhibitory regulation to glucagon gene transcription. 


\subsubsection{Insulin receptor (IR)}

The insulin receptor (IR) belongs to a family of receptors which posses a tyrosine kinase activity. This receptor is a heterotetramer, with two identical $\alpha$ chains (135 kDa each) and two identical $\beta$ chains (95 kDa each) bound by disulfide linkages ( $\beta-\alpha-\alpha-\beta)$. The $\alpha$ subunits are entirely extracellular, while the $\beta$ subunits contain an extracellular portion, a transmembrane region and an intracellular domain that includes a tyrosine kinase (TK) active site (Ottensmeyer et al., 2000). In the absence of insulin, $\alpha$ subunits maintain the IR in the inactive conformation. When insulin is present, it binds to the $\alpha$ subunits causing a conformational change, bringing the $\beta$ subunits into closer contact. This contact leads to phosphorylation and activation of the tyrosine kinase activity of the IR. The tyrosine kinase activity generates further trans- and autophosphorylation that are responsible for the transduction of the insulin signal since the phosphotyrosines (P-Tyr) in the juxtamembrane domain are docking sites for the insulin receptor substrate proteins.

The insulin-IR complexes are actively internalized into endosomes, where the hormone is degraded. Although some of the insulin receptors are also degraded in the endosome, an important part of them is recycled to the membrane. Under physiological conditions, the newly synthesized IR restores the number of receptors in an $\alpha$-cell to normal level. However, under certain conditions the levels of the receptor are downregulated interfering with downstream signaling events. The mechanism of downregulation of the insulin receptor has been studied in many models of insulin resistance, but has not been yet studied in pancreatic islet $\alpha$-cells.

\subsubsection{Insulin receptor substrate proteins (IRS)}

The IR transmits its signal by specific phosphorylation of members of a family of cytosolic proteins known as the insulin receptor substrate proteins (IRS) (Thirone et al., 2006). There are several proteins belonging to this family: IRS-1, IRS-2, IRS-3, IRS-4 and Gab-1. Even though these proteins do not have catalytic activity, their phosphorylation creates binding sites for adapter proteins and enzymes that propagate and amplify the signal. IRS have several tyrosines within specific motifs, which are recognized by proteins containing a Src homology-2 (SH-2) domain, allowing the activation of multiple pathways simultaneously. IRS are also substrates for the insulin-like growth factor receptor (IGFR) 
tyrosine kinase and for Janus kinases (JAKs) (Boron and Boulpaep, 2004). There are two major IRS-signaling pathways, one mediated by phosphatidylinositol 3-kinase (PI3K) and the other mediated by Ras / mitogen-activated protein kinase (MAPK). The first pathway begins with phosphorylation of SHC (Src homology, C terminus) and activation of the adaptor protein guanine nucleotide exchange factor (Grb2), which triggers the Ras / mitogen-activated protein kinase (MAPK) signaling pathway (Kumar and O'Rahily, 2005). The second pathway, the PI3K pathway, begins with the activation of PI3K, which phosphorylates a membrane lipid to signal through several steps (see below). Interestingly, both pathways act through the transcriptional regulation of specific genes.

\subsubsection{Phosphoinositide 3-Kinase (PI3K)}

The PI3K pathway leads to important changes in glucose and protein metabolism (Katso et al., 2001). Phosphorylated IRS-1 and IRS-2 act as highly efficient scaffolds in the recruitment of PI3K activity. PI3K is a kinase containing a catalytic subunit ( $\mathrm{p} 110)$ and an adaptor / regulatory subunit (p85 / p55). The lipid kinase activity of PI3K phosphorylates phosphatidyl inositol-4-5-biphosphate $\left(\mathrm{PIP}_{2}\right)$ to form phosphatidyl inositol-3-4-5triphosphate (PI-3,4,5- $\left.\mathrm{P}_{3}\right)$, which in turn activates serine / threonine (Ser / Thr) phosphatidyl inositol-dependent kinases (PDKs). PI3K also possess a serine kinase activity, which catalyzes the autophosphorylation of its adaptor subunit. Signaling by PI3K is terminated by the action of specific phosphatases. Two major classes of phosphatases act on PI-3,4,5- $\mathrm{P}_{3}$ : the phosphatase and tensin homolog (PTEN), which possesses a $3^{\prime}-$ phosphatase activity, and the SH2-containing inositide phosphatase (SHIP) family of phosphatases. Both of these phosphatase classes effectively reverse the PI3K reaction (Kumar and O'Rahily, 2005). It is important to mention that the phosphorylation of particular serine residues of IRS proteins by specific serine kinases negatively regulates signaling downstream of PI3K (Draznin, 2006).

\subsubsection{Protein kinase B (PKB)}

The activated forms of PDKs phosphorylate protein kinase B (PKB, also known as Akt) rendering it active. The Ser / Thr kinase PKB is a $57 \mathrm{kDa}$ protein structurally related with the cAMP-dependent protein kinase $A$ and the calcium / lipid-dependent kinase $C$. There are three mammalian isoforms of this kinase, which share high homology: PKB $\alpha$ / Akt1, PKB $\beta$ / Akt2 and PKB $\gamma$ / Akt3. This kinase consists of a N-terminal pleckstrin homology 
domain (PH domain), a central catalytic kinase domain and a C-terminal tail. The $\mathrm{PH}$ domain of PKB binds with high affinity $\mathrm{PI}-3,4,5-\mathrm{P}_{3}$ and its immediate breakdown product phosphatidyl inositol-3-4-bisphosphate. In addition to this binding, activation of PKB requires its phosphorylation at two sites, one within the activation loop of the kinase domain Thr 308 in $\mathrm{PKB} \alpha$ and the other within the C-terminal hydrophobic motif Ser 473 in $\mathrm{PKB} \alpha$ (Kumar and O'Rahily, 2005). PKB mediates biological effects of insulin such as stimulation of GLUT4-dependent glucose transport, glycogen synthesis and protein synthesis and the suppression of hepatic gluconeogenesis (Whiteman et al., 2002). In addition to phosphorylating substrates involved in these processes, PKB forms complexes with other proteins that modulate its own activity and function. Impaired PKB function has been found to cause insulin resistance and diabetes mellitus in human and in animal models (Cho et al., 2001; George et al., 2004; Schinner et al., 2005b). One of the proteins that has been recently suggested to inhibit PKB activation by insulin in the liver is the mammalian homologue of the Drosophila protein TRB3 (tribbles 3) (Du et al., 2003). TRB3 seems to interfere with PKB activation, thus impairing insulin signaling (Du et al., 2003) and leading to insulin resistant states (Koo et al., 2004).

\subsubsection{Glycogen synthase kinase $\beta$ (GSK3ß)}

Active PKB phosphorylates and modulates multiple cellular substrates, including glycogen synthase kinase-3 beta (GSK3 $\beta$ ), phosphodiesterase-3B (PDE-3B), phosphofructokinase2 (PFK-2), forkhead transcription factors of the FOXO family, the Bcl-2 family member Bad and caspase 9 (Sen et al., 2003). GSK3 $\beta$ is an ubiquitously expressed serine / threonine kinase involved in a wide variety of biological processes including metabolism, cell fate determination, neurological disorders and transcriptional control (Patel et al., 2004). PKB phosphorylates GSK3- $\beta$ thereby inhibiting its activity and relieving the inhibitory effect of GSK3- $\beta$ on glycogen synthase (GS). This regulation is a major mechanism by which insulin stimulates glycogen synthesis in skeletal muscle (Frame et al., 2001). In addition, GSK3 $\beta$ alters or disrupts nucleoprotein complexes on the glucagon promoter (Dimopoulos, 2003). 


\subsubsection{Transcription factor Pax 6}

A similar mechanism as the one described for GSK3 $\beta$ for the disruption of nucleoprotein complexes on the glucagon promoter has been suggested for the complex formed between the transcription factor Pax 6 and its coactivator CBP (Schinner et al., 2005a). Pax 6 is a member of the Pax gene family. The Pax 6 gene encodes a transcription factor that contains both a paired domain and a paired-like homeodomain (Callaerts et al., 1997). Among other tissues, Pax 6 is expressed in the pancreas. Pax 6 can bind to the pancreatic islet cell enhancer sequence (PISCES) localized in different promoters (insulin, glucagon and somatostatin genes) (Huang and Tsai, 2000). By binding to PISCES, Pax 6, together with other transcription factors, plays an important role in the activation of transcription of specific genes (Huang and Tsai, 2000). Pax 6 requires the binding of coactivators such as CREB binding protein (CBP) in order to activate gene transcription (Hussain and Habener, 1999).

\subsubsection{Coactivator CREB binding protein (CBP)}

The cyclic AMP response element (CRE)-binding protein CREB, activates the transcription of target genes in response to a diverse array of stimuli (cAMP-, calcium-, and ERK / p38 MAPK activated signaling pathways) (Habener et al., 1995; Mayr et al., 2001). In order to activate gene transcription, CREB associates with the transcriptional adaptor CREBbinding protein (CBP). CBP was cloned as a $265 \mathrm{kDa}$ nuclear protein, which shares sequence similarity with the protein $\mathrm{p} 300$, which as well mediates CREB function. Nevertheless, it has been shown that certain active forms or CREB (i.e. Ser-133phosphorylated CREB) require the association with CBP but not with p300. CBP acts as a transcriptional adaptor between Ser 133-phosphorylated CREB and the basal transcription machinery. CBP also possesses a histone acetyltransferase (HAT) activity. CBP catalyzes the acetylation of lysine residues in the $\mathrm{N}$-termini of histones. This renders the DNA template more accessible to the transcriptional machinery (Shaywitz and Greenberg, 1999).

\subsection{Glucagon gene transcription and the glucagon promoter}

One of the main targets of the insulin-signaling cascade in the transcriptional regulation of genes is the glucagon gene. Even though the regulation of the expression of the glucagon 
gene is not yet fully understood (Laser et al., 1996), several experiments using transgenic mice (Efrat et al., 1988; Lee et al., 1992), cell-free in vitro transcription systems (Knepel, 1993) and tumor cell lines (Drucker et al., 1987b; Philippe et al., 1988) suggest that $\alpha$ pancreatic activation of the glucagon gene is regulated through the 5'-flanking region of the glucagon promoter. A detailed study of the glucagon promoter showed that 350 base pairs of the 5'-flanking region contained sequences necessary to confer insulin responsiveness (Philippe, 1989) (Figure 4). The fusion of this $350 \mathrm{bp}$ with a luciferase reporter gene, has become an important tool for the study of the transcriptional regulation of the glucagon gene in glucagon-producing islet tumor cell lines (Philippe et al., 1988). Moreover, regulatory elements within the glucagon promoter have been identified (CordierBussat et al., 1995). These elements, including several nuclear proteins (i.e. transcription factors, coactivators, etc.), act in a concerted way to provide a tight regulation of glucagon gene expression. The transcriptional regulation of the glucagon gene is achieved by binding of transcription factors to specific sequences at the promoter (Drucker et al., 1987a; Efrat et al., 1988; Knepel, 1993; Lee et al., 1992; Philippe et al., 1988). This promoter contains proximal promoter elements (G1 and G4) and more distal enhancer-like elements (G2, G3 and CRE) (Philippe et al., 1995) that are essential for insulin responsiveness (Grzeskowiak et al., 2000). However, insulin responsiveness is not conferred by a single insulin-responsive element within the glucagon promoter, but through the synergistic interaction of both proximal promoter and more distal enhancer-like elements (Grzeskowiak et al., 2000). Transcription factors such as Pax 6 and its coactivator CBP are essential elements providing insulin responsiveness in pancreatic $\alpha$ cells (Grzeskowiak et al., 2000; Philippe et al., 1995).

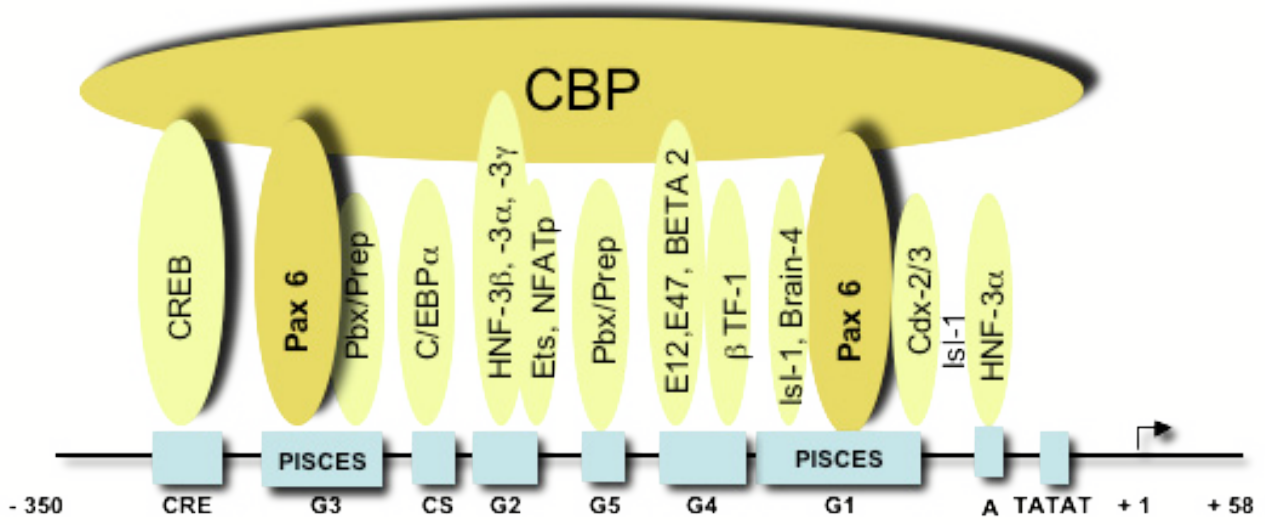

Figure 4. Control cis-elements within the glucagon promoter and their corresponding transcription factors. This figure shows the "state of the art" transcription factors binding to DNA control elements within the glucagon promoter. 


\subsection{Factors inducing insulin resistance}

Insulin resistance is closely related to a range of common diseases, including type II diabetes mellitus, polycystic ovary syndrome, obesity and hypertension. Several factors and mechanisms have been proposed in the induction of insulin resistance including increased non-esterified fatty acids, inflammatory cytokines and adipokines, mitochondrial dysfunction, glucotoxicity and lipotoxicity. Although some of the mechanisms of these factors have been directly associated with a defective insulin signaling (Capeau, 2005; Chakraborty, 2006; Musi and Goodyear, 2006), it has been suggested that other hormones and signal cascades (Kumar and O'Rahily, 2005) contribute to the development of insulin resistance.

\subsubsection{Adipokines}

In recent years, in addition to its role as a storage depot for lipids, the adipose tissue has been recognized as a source of a number of hormones collectively called adipokines (Guerre-Millo, 2004; Hammarstedt et al., 2005; Jazet et al., 2003; Ronti et al., 2006; Schinner et al., 2005b; Trotti et al., 2001). These hormones play an important role in the regulation of insulin sensitivity of insulin target tissues. As well, adipokines influence metabolism and energy expenditure. Elevated levels of some of these hormones have been detected within insulin resistant states (Arner, 2005; Guerre-Millo, 2004; Jazet et al., 2003). Adipokines that have been involved in the induction of insulin resistance are TNF $\alpha$ (Hotamisligil, 1999; Hotamisligil et al., 1994), IL-6 (Rotter et al., 2003), IL-1 $\beta$ and resistin (Steppan and Lazar, 2002). Other cytokines, like the insulin sensitizer adiponectin (Yamauchi et al., 2001) and leptin (Shimomura et al., 1999) reverse insulin resistance (Kadowaki and Yamauchi, 2005). In addition, visfatin, an adipocyte-derived protein with a diabetogenic effect, has been discovered (Hug and Lodish, 2005). The mechanism through which these molecules exert their action is still not well understood (Hotamisligil, 2000).

\subsubsection{Free fatty acids and other insulin resistance-inducing molecules}

Furthermore, the adipose tissue modulates the metabolism of the whole body through the regulation of levels of circulating free fatty acids (FFA). It has been shown that elevated levels of circulating FFA can impair insulin sensitivity in humans (Perseghin et al., 1997). 
On the other hand, FFA are considered ligands for nuclear receptors of the family of the peroxisome proliferator-activated receptor gamma (PPAR $\gamma$ ) (Forman et al., 1997; Kliewer et al., 1997; Xu et al., 1999). This nuclear receptor is involved in a broad range of cellular functions, including adipocyte differentiation (Grimaldi, 2001), inflammatory responses (Moraes et al., 2006) and apoptosis (Moraes et al., 2006; Strakova et al., 2005). Of particular importance is the role of PPARs in glucose homeostasis and type II diabetes mellitus. PPAR $\gamma$ in combination with synthetic PPAR $\gamma$ ligands, thiazolidinediones, ameliorate insulin resistance (Olefsky, 2000; Olefsky and Saltiel, 2000) and as a secondary effect reduce hepatic glucose output (Schinner et al., 2002).

\subsection{Aim of the study}

The aim of the present work was to identify signals that are able to confer insulin resistance to pancreatic $\alpha$-cells. This was accomplished by studying the effect of different substances, involved in the induction of insulin resistance in other tissues, on the regulation of glucagon gene transcription by insulin. Transient transfection experiments using the glucagon-producing cell line InR1G9 and a glucagon-reporter fusion gene were performed to find which of the substances were able to induce insulin resistance at the level of the pancreatic $\alpha$-cell. A further aim was to elucidate the step within the insulinsignaling pathway to the glucagon gene, at which these substances interfered. 


\section{MATERIALS}

\subsection{Equipment}

Autoclave
Balances
Camera
Cell culture hood
Centrifuge rotors
Centrifuges
Electrophoresis chamber (DNA)
Electrophoresis chamber
(proteins)
Electrophoresis power supply
Standard Power Pack 25
Incubators

Light microscope

Luminometer

Micro pipettes

Micro plate reader for GFP

Microwave oven

$\mathrm{pH}$ meter

Pipetus akku

Refrigerator

REVCO (Freezer $-80^{\circ} \mathrm{C}$ )

Rocking platform

Scanner

Shakers

Spectrophotometer

Thermomixer

Semi-dry transfer device

Vacuum Pump

Waterpump

Waterbath

Wet transfer device

X-ray Cassettes

$\mathrm{X}$-Omatic Regular screen
Bioclav, Schütt Labortechnik, Göttingen

Sartorius AG, Göttingen

Hamamatsu Digital CCD Kamera,

Lamin Air, Heraeus, Hanau

JA-20 / JA-17 / JA-14, Ti 70, Beckamnn GmbH, Krefeld

1) Megafuge-Biofuge, Heraeus $\mathrm{GmbH}$, Hanau

2) Eppendorf 5417R, Eppendorf $\mathrm{GmbH}$, Hamburg

3) Beckmann J2-HS, Beckmann GmbH, Krefeld

4) Ultracentrifuge L8-70M, Beckmann®, Beckmann, Roth, Karlsruhe

Mighty Small SE 250 / SE 260, Hoefer, San

Francisco, US

Biometra, Göttingen

Sanyo, Japan

1) for bacteria: Heraeus $\mathrm{GmbH}$, Hanau

2) for cells: Labotect, Göttingen

Nikon TMS, Japan

AutoLumat LB 953, Berthold Technologies, Bad

Wildbald

Gilson, France

Fusion $^{\text {TM }}$, Packard, Switzerland

Phillips, Whirlpool, UK

pH 523, Schütt Labortechnik, Göttingen

Hirschmann Laborgeräte, Göttingen

Bosch, Göttingen

Sanyo EWALD Innovationstechnik, GmbH

Biometra, Göttingen

Hewlett Packard, Scanjet 3770, Hannover

Rocking platform, Biometra, Göttingen

Shimadzu UV-160, Duisburg

Eppendorf, Hamburg

Bender \& Hobein, Switzerland

KnF Laboport, Neuberger

Schütt Labortechnik, Göttingen

W. Krannich $\mathrm{GmbH}$, Göttingen

Hoefer-Serva, Heidelberg

Eastman KODAK Company, New York 


\subsection{Materials}

Cell culture dishes

Disposable cell scraper

ECL- $X$ ray films

Eppendorf tubes

$15,50 \mathrm{ml}$ tubes

Filter units

Glass pipettes

Glassware

Nitrocellulose membrane

Pasteur pipettes

Petri-dishes $(10$ or $15 \mathrm{~cm}$ )

Pipette tips

Plastic tubes for luminometer (5

$\mathrm{ml})$

Spectrophotometer cuvettes

(plastic)

Spectrophotometer cuvettes

(quartz)

Syringes

Syringe filters

Syringe needles

Ultracentrifuge tubes

Whatman paper P81

96 Well plates

\subsection{Chemicals}

Acetic acid

Acrylamide

Agarose

Albumin for microbiology

Albumin fraction $\mathrm{V}$

Ammonium chloride

Ammonium persulfate

Ampicillin sodium salt

ATP

Bis-acrylamide

Boric acid

8-Bromoadenosine 3'-5'

monophosphate

Bromophenol blue

Calcium chloride dihydrate

Cesium chloride

Chloroamphenicol

Chloroquine

Cycloheximide

Cyclosporin A
Becton Dickinson, France

Sarstedt, Nümbrecht

Amersham Biosciences, Freiburg

Eppendorf, Hamburg

Greiner Bio-one, Solingen

Sartolab, Biofiltronic $\mathrm{GmbH}$, Nörten-Hardenberg

WU, Mainz

Schott Duran, Mainz

Hybond $^{\mathrm{TM}}$, ECL ${ }^{\mathrm{TM}}$, Amersham Biosciences Freiburg

Brand, Wertheim / Main

Greiner, Frickenhausen

Sarstedt, Nümbrecht

Sarstedt, Nümbrecht

Sarstedt, Nümbrecht

Sarstedt, Nümbrecht

BD Discardit II, Beckton Dickinson, Spain

Sartorius, Göttingen

Sterican, B / BRAUN, Melsungen

Beckman $\mathrm{GmbH}$, Krefeld

Whatman, Maidstone, UK

Greiner Bio-one $\mathrm{GmbH}$, Friekenhäusen
Applichem GmbH, Darmstadt Applichem $\mathrm{GmbH}$, Darmstadt Invitrogen, UK

Applichem $\mathrm{GmbH}$, Darmstadt Applichem $\mathrm{GmbH}$, Darmstadt Applichem $\mathrm{GmbH}$, Darmstadt Applichem $\mathrm{GmbH}$, Darmstadt Applichem $\mathrm{GmbH}$, Darmstadt Applichem $\mathrm{GmbH}$, Darmstadt Applichem $\mathrm{GmbH}$, Darmstadt Applichem GmbH, Darmstadt SIGMA-Aldrich $\mathrm{GmbH}$, Steinheim

SIGMA-Aldrich $\mathrm{GmbH}$, Steinheim Merk, Darmstadt

Applichem $\mathrm{GmbH}$, Darmstadt SIGMA-Aldrich $\mathrm{GmbH}$, Steinheim SIGMA-Aldrich $\mathrm{GmbH}$, Steinheim SIGMA-Aldrich $\mathrm{GmbH}$, Steinheim Gift from Novartis, Bassel 


DEAE-Dextran
Dexamethasone
DMSO
D-saccharose
DTT
EDTA
EGTA
Ethanol
Ethidium bromide
Forskolin
Glycerol
Glycine
Glycylglycine
Hydrochloric acid
Isopropanol
Lactacystin
Leupeptin
Low fat milk
Luciferine
Lysozyme
Lytic buffer
Magnesium chloride
Magnesium sulfate heptahydrate
Methanol
MG132
Okadaic acid
PEG 6000
Pepstatin A
Peptone from casein
Phorbol 12-myristate 13-acetate
PIPES
PMSF
Porcine insulin
Potassium chloride
Potassium diphosphate
Potassium phosphate
SDS
Select agar
Select peptone
Select yeast extract
Sodium bicarbonate
Sodium chloride
Sodium fluoride
Sodium hydroxide
Sodium orthovanadate
Sucrose
Tacrolimus (FK506)
TEMED
Tris
Triton X-100
Tween 20

B-mercaptoethanol

Amersham Pharmacia Biotech AB, Sweden

SIGMA-Aldrich $\mathrm{GmbH}$, Steinheim

Applichem $\mathrm{GmbH}$, Darmstadt

Applichem $\mathrm{GmbH}$, Darmstadt

Applichem $\mathrm{GmbH}$, Darmstadt

Applichem $\mathrm{GmbH}$, Darmstadt

Applichem $\mathrm{GmbH}$, Darmstadt

Applichem $\mathrm{GmbH}$, Darmstadt

SIGMA-Aldrich $\mathrm{GmbH}$, Steinheim

SIGMA-Aldrich GmbH, Steinheim

Applichem $\mathrm{GmbH}$, Darmstadt

Applichem $\mathrm{GmbH}$, Darmstadt

Applichem $\mathrm{GmbH}$, Darmstadt

Applichem $\mathrm{GmbH}$, Darmstadt

Applichem $\mathrm{GmbH}$, Darmstadt

SIGMA-Aldrich $\mathrm{GmbH}$, Steinheim

Applichem $\mathrm{GmbH}$, Darmstadt

Applichem $\mathrm{GmbH}$, Darmstadt

Promega, Mannheim

Applichem $\mathrm{GmbH}$, Darmstadt

SIGMA-Aldrich $\mathrm{GmbH}$, Steinheim

SIGMA-Aldrich $\mathrm{GmbH}$, Steinheim

Applichem $\mathrm{GmbH}$, Darmstadt

Applichem $\mathrm{GmbH}$, Darmstadt

Calbiochem, Darmstadt

SIGMA-Aldrich $\mathrm{GmbH}$, Steinheim

Applichem $\mathrm{GmbH}$, Darmstadt

Applichem $\mathrm{GmbH}$, Darmstadt

Applichem $\mathrm{GmbH}$, Darmstadt

SIGMA-Aldrich $\mathrm{GmbH}$, Steinheim

SIGMA-Aldrich $\mathrm{GmbH}$, Steinheim

Applichem $\mathrm{GmbH}$, Darmstadt

SIGMA-Aldrich $\mathrm{GmbH}$, Steinheim

Applichem $\mathrm{GmbH}$, Darmstadt

Applichem $\mathrm{GmbH}$, Darmstadt

Applichem $\mathrm{GmbH}$, Darmstadt

Applichem $\mathrm{GmbH}$, Darmstadt

Applichem $\mathrm{GmbH}$, Darmstadt

Applichem $\mathrm{GmbH}$, Darmstadt

Applichem $\mathrm{GmbH}$, Darmstadt

Applichem $\mathrm{GmbH}$, Darmstadt

Applichem $\mathrm{GmbH}$, Darmstadt

SIGMA-Aldrich $\mathrm{GmbH}$, Steinheim

Merk, Darmstadt

SIGMA-Aldrich $\mathrm{GmbH}$, Steinheim

Applichem $\mathrm{GmbH}$, Darmstadt

Fujisawa $\mathrm{GmbH}$, München

Applichem $\mathrm{GmbH}$, Darmstadt

Applichem $\mathrm{GmbH}$, Darmstadt

SIGMA-Aldrich $\mathrm{GmbH}$, Steinheim

Applichem $\mathrm{GmbH}$, Darmstadt

Applichem $\mathrm{GmbH}$, Darmstadt 


\subsection{Eukaryotic cell lines}

The following cell line was used: glucagon-producing golden hamster pancreatic tumor cell line, InR1G9 ( $\alpha$-cell phenotype)(Takaki et al., 1986).

\subsection{Reagents for cell culture}

\begin{tabular}{|c|c|}
\hline $\begin{array}{l}\text { Albumin, FFA free, cell culture } \\
\text { ested }\end{array}$ & Idrich $C$ \\
\hline Bovine Serum & GIBCO-BRL, Karlsruhe \\
\hline terleukin-6 & Strathmann Biotec AG, Hambu \\
\hline $\begin{array}{l}\text { Human tumor necrosis factor } \\
\text { alpha }\end{array}$ & Strathmann Biotec AG, Hambu \\
\hline ic acid & Aldrich $\mathrm{GmbH}, \mathrm{St}$ \\
\hline & Aldrich $\mathrm{GmbH}$, Ste \\
\hline terleukin-1 beta & $\mathrm{CAG}, \mathrm{Ha}$ \\
\hline Ole & SIGMA-Aldrich $\mathrm{GmbH}$, Ste \\
\hline Palm & SIGMA-Aldrich GmbH, Ste \\
\hline in-streptomycin solutior & GIBCOBRL, Karlsruhe \\
\hline 0 medium & GIBCO BRL, Karlsruhe \\
\hline & Aldrich $\mathrm{GmbH}, \mathrm{St}$ \\
\hline$A$ & $\mathrm{O}^{\mathrm{TM}}$-Invitrogen \\
\hline
\end{tabular}

\subsection{Media for cell culture}

Buffers were prepared following "Molecular Cloning" Laboratory manual (Sambrook et al., 1989):

\section{RPMI 1640 (10L)}

$\mathrm{NaHCO}_{3}$

RPMI medium powder

GIBCO Cat. 51800-035

Volume adjusted to $10 \mathrm{~L}$ with distilled water

Filter sterilized ( $0.2 \mu \mathrm{m}$ filter cartridge)

\section{RPMI complete}

Fetal bovine serum

Penicillin-streptomycin solution

RPMI 1640

$50 \mathrm{ml}$

$5 \mathrm{ml}$

add to $500 \mathrm{ml}$

\section{RPMI incomplete}

RPMI 1640

Penicillin-streptomycin solution add to $500 \mathrm{ml}$

$5 \mathrm{ml}$ 
BSA

Penicillin-streptomycin solution

RPMI 1640

Sterilize through filter $0.2 \mu \mathrm{m}$

\section{$2.5 \mathrm{~g}$}

$5 \mathrm{ml}$

add to $500 \mathrm{ml}$

\section{RPMI + $0.5 \%$ fatty acid free BSA + FFA}

Solution 1) Dissolve $1.0 \mathrm{~g}$ BSA FFA free, cell culture tested in $20 \mathrm{ml}$ PBS (gently agitation, place on $40{ }^{\circ} \mathrm{C}$ water bath)

Solution 2) Dissolve desired FFA (see molecular weight tables and FFA amounts to obtain the desired molarity) in $4 \mathrm{ml}$ ethanol

Add $4 \mathrm{ml}$ of a $20 \mathrm{mM} \mathrm{Na}_{2} \mathrm{CO}_{3}$

Evaporate the ethanol (under slight $\mathrm{N}_{2}$ flow, approx. $1-1.5 \mathrm{~h}$ )

Detect whether ethanol is still on Solution 2 (smell)

Solution 3) Mix $4 \mathrm{ml}$ of ethanol with $4 \mathrm{ml}$ of $20 \mathrm{mM} \mathrm{Na}_{2} \mathrm{CO}_{3}$ (control without FFA)

Evaporate the ethanol (under slight $\mathrm{N}_{2}$ flow, approx. $1-1.5 \mathrm{~h}$ )

Detect whether ethanol is still on Solution 3 (smell)

Divide solution 1 into two $10-\mathrm{ml}$ aliquots

Add drop wise solution 2 or solution 3 to their respective solution 1 aliquots (under constant gentle agitation)

Filtrate through $0.2 \mu \mathrm{m}$ solution $1+2$ or solution $1+3$ into $85 \mathrm{ml}$ of RPMI medium Add $1 \mathrm{ml}$ of penicillin-streptomycin solution to each solution

Incubate both solutions at $37^{\circ} \mathrm{C}$ in a $\mathrm{CO}_{2}$ incubator (approx. $1 \mathrm{~h}$ )

\subsection{Stock solutions}

Ampicillin

ATP

Chloramphenicol

Dithiothreitol

Ethidium Bromide

Insulin

$$
\begin{aligned}
& 50 \mathrm{mg} / \mathrm{ml} \\
& 200 \mu \mathrm{M} \\
& 34 \mathrm{mg} / \mathrm{ml}^{*} \\
& 1 \mathrm{M} \\
& 10 \mathrm{mg} / \mathrm{ml} \\
& 10 \mu \mathrm{M}
\end{aligned}
$$

${ }^{*}$ : dissolved in ethanol. All other substances were dissolved in water.

\subsection{Reporter gene plasmids and expression plasmids}

\author{
pBluescript \\ pCDNA3-FT-TRB-3 \\ human-PPAR $\gamma$ - wt FLAG tag \\ pCMV4-PKB myr $_{\text {r }}$ \\ pCMV4-PKB myr $-K 179 M$ \\ pCVMV-GFPtpz \\ pXP2-350GluLuc
}

Stratagene, La Jolla, US

S. Herzig, Heidelberg, Germany

Chatterjee. Cambridge, UK

Columbia University, Columbia, US

modified from plasmid Columbia University

Columbia, US

Cranberra-Packard, Dreieich Germany

Schwaninger et al., 1993 


\subsection{Restriction enzymes and buffers}

\subsubsection{Enzymes}

\section{BamHI \\ BgllI \\ EcoRI \\ HindIII \\ Pvull \\ Sacl \\ Smal \\ Xbal}

\subsubsection{Enzyme buffers}

Buffer G

Buffer O

$\mathrm{Y}+/$ Tango 2X (contains BSA)

\subsection{Markers}

Gene Ruler $1 \mathrm{~Kb}$ DNA ladder Page Ruler
MBI Fermentas, St. Leon-Rot MBI Fermentas, St. Leon-Rot MBI Fermentas, St. Leon-Rot MBI Fermentas, St. Leon-Rot MBI Fermentas, St. Leon-Rot MBI Fermentas, St. Leon-Rot MBI Fermentas, St. Leon-Rot MBI Fermentas, St. Leon-Rot

MBI Fermentas, St. Leon-Rot MBI Fermentas, St. Leon-Rot MBI Fermentas, St. Leon-Rot

MBI Fermentas, St. Leon-Rot MBI Fermentas, St. Leon-Rot

\subsection{Antibodies}

\subsubsection{Primary antibodies}

\begin{tabular}{|l|c|c|c|c|}
\hline \multicolumn{1}{|c|}{ Antibody name } & Source & Clone & Dilution & Company \\
\hline Anti-Akt & Rabbit & Polyclonal & $1: 2,500$ & Cell Signaling, US \\
\hline $\begin{array}{l}\text { Anti-insulin receptor } \\
\text { beta (L55B10) }\end{array}$ & Mouse & Monoclonal & $1: 1,000$ & Cell Signaling, US \\
\hline $\begin{array}{l}\text { Anti-insulin receptor } \\
\text { beta(4B8) }\end{array}$ & Rabbit & Polyclonal & $1: 1,000$ & Cell Signaling, US \\
\hline Anti-IRS-1 & Rabbit & Polyclonal & $1: 1,000$ & Cell Signaling, US \\
\hline Anti-P-IRS-1 (Tyr 612) & Rabbit & Polyclonal & $1: 1,000$ & $\begin{array}{c}\text { Biosource } \\
\text { International, US }\end{array}$ \\
\hline $\begin{array}{l}\text { Anti-P-IGF-I receptor } \\
\text { (Tyr1135/1136)/ } \\
\text { insulin Receptor } \\
\text { (Tyr1150/1151) } \\
\text { (19H7) }\end{array}$ & Rabbit & Monoclonal & $1: 1,000$ & Cell Signaling, US \\
\hline
\end{tabular}




\begin{tabular}{|l|c|c|c|c|}
\hline Anti-Ser 473-Akt & Rabbit & Polyclonal & $1: 2,500$ & Cell Signaling, US \\
\hline mAb 21-B1 & Mouse & Monoclonal & $10 \mu \mathrm{g} / \mathrm{ml}$ & $\begin{array}{c}\text { Bünemann et al., } \\
1999\end{array}$ \\
\hline Anti-GAPDH & Rabbit & Polyclonal & $1: 500$ & $\begin{array}{c}\text { Santa Cruz } \\
\text { Biotechnology }\end{array}$ \\
\hline
\end{tabular}

\subsubsection{Secondary antibodies}

\begin{tabular}{|l|l|l|c|c|}
\hline Antibody name & Source & Clone & Dilution & Company \\
\hline $\begin{array}{l}\text { Peroxidase labeled } \\
\text { anti-rabbit }\end{array}$ & Donkey & Polyclonal & $1: 10,000$ & $\begin{array}{c}\text { ECL western blotting } \\
\text { detecting reagents, } \\
\text { Amersham } \\
\text { Biosciences, Freiburg }\end{array}$ \\
\hline $\begin{array}{l}\text { Peroxidase labeled } \\
\text { anti-mouse }\end{array}$ & Sheep & Polyclonal & $1: 10,000$ & $\begin{array}{c}\text { ECL western blotting } \\
\text { detecting reagents, } \\
\text { Amersham } \\
\text { Biosciences, Freiburg }\end{array}$ \\
\hline
\end{tabular}

\subsection{Western blot detection}

ECL western blotting reagent 1 Amersham Biosciences, Freiburg

and 2

Developer solution LX24 Kodak

Fixing solution AL4 Kodak 


\section{METHODS}

\subsection{Preparation of $\mathrm{Ca}^{2+}$ competent $\mathrm{DH} 5 \alpha$ cells}

\section{Solutions and reagents}

\section{$50 \mathrm{mM} \mathrm{CaCl} 2(100 \mathrm{ml})$}

$\mathrm{CaCl}_{2}$

Add to $100 \mathrm{ml}$ with distilled water

Autoclave $20 \mathrm{~min}$ at $120^{\circ} \mathrm{C}$ at $15 \mathrm{psi}$.

\section{$50 \mathrm{mM} \mathrm{CaCl} 2+15 \%$ glycerol}

$\begin{array}{ll}87 \% \text { Glycerol } & 5.62 \mathrm{ml} \\ 50 \mathrm{mM} \mathrm{CaCl}_{2} & 26.5 \mathrm{ml}\end{array}$

$0.2 \mu \mathrm{m}$ sterile filtered

\section{LB (without antibiotics) (1L)}

$\begin{array}{ll}1 \%(\mathrm{w} / \mathrm{v}) \mathrm{NaCl} & 10 \mathrm{~g} \\ 1 \%(\mathrm{w} / \mathrm{v}) \text { Peptone from casein } & 10 \mathrm{~g} \\ 0.5 \%(\mathrm{w} / \mathrm{v}) \text { Yeast extract } & 5 \mathrm{~g}\end{array}$

Add with distilled water to $1 \mathrm{~L}$

Autoclave $20 \mathrm{~min}$ at $120^{\circ} \mathrm{C}$ at $15 \mathrm{psi}$.

\section{Agar plates (without antibiotics) $(500$} $\underline{\mathrm{ml}}$

$1.5 \%$ (w / v) Agar

Add to $500 \mathrm{ml}$ with LB medium

Liquid nitrogen

\section{$7.5 \mathrm{~g}$}

Autoclave $20 \mathrm{~min}$ at $120^{\circ} \mathrm{C}$ at $15 \mathrm{psi}$.

\section{Preparation procedure}

E. coli competent cells were prepared following the calcium chloride $\left(\mathrm{CaCl}_{2}\right)$ procedure. Briefly, $10 \mathrm{ml}$ of LB media were inoculated with one colony of $\mathrm{DH} 5 \alpha$ cells and with this preculture, a $100 \mathrm{ml}$ LB culture was inoculated and grown at $37^{\circ} \mathrm{C}$ (200 rpm). $\mathrm{OD}_{600}$ was measured until it reached a value of 0.6. Cells were centrifuged for $10 \mathrm{~min}$ at 3,000 rpm and the SN was disposed. The pellet was resuspended in $50 \mathrm{ml}$ of a cold sterile $50 \mathrm{mM}$ 
$\mathrm{CaCl}_{2}$ solution and kept on ice for $30 \mathrm{~min}$. The cells were centrifuged again under the same conditions and the pellet was now resuspended in a cold solution of $50 \mathrm{mM} \mathrm{CaCl}$ containing $15 \%$ glycerol. Cells were aliquoted into $100 \mu \mathrm{l}$ aliquots in $1.5 \mathrm{ml}$ eppendorf tubes. Cells were immediately frozen in liquid $\mathrm{N}_{2}$ and kept at $-80^{\circ} \mathrm{C}$ until their use.

\subsection{Transformation of E. coli DH5a}

\section{Solutions and reagents}

\section{LB medium (1L)}

$\begin{array}{ll}1 \%(\mathrm{w} / \mathrm{v}) \mathrm{NaCl} & 10 \mathrm{~g} \\ 1 \%(\mathrm{w} / \mathrm{v}) \text { Peptone from casein } & 10 \mathrm{~g} \\ 0.5 \%(\mathrm{w} / \mathrm{v}) \text { select yeast extract } & 5 \mathrm{~g} \\ \text { Add with distilled water to } 1 \mathrm{~L} & \\ \text { Autoclave } 20 \mathrm{~min} \text { at } 120^{\circ} \mathrm{C} \text { at } 15 \text { psi. } & \end{array}$

\section{LB agar dishes + ampicillin $(500 \mathrm{ml})$}

$1.5 \%(\mathrm{w} / \mathrm{v})$ select agar

Add to $500 \mathrm{ml}$ with LB medium

Autoclave $20 \mathrm{~min}$ at $120^{\circ} \mathrm{C}$ at $15 \mathrm{psi}$.

$50 \mu \mathrm{g} / \mathrm{ml}$ Ampicillin

$0.5 \mathrm{ml}$ of a $50 \mathrm{mg} / \mathrm{ml}$

\section{Transformation procedure}

$5 \mathrm{ng}$ of DNA of the desired plasmid was added to $\mathrm{DH} 5 \alpha$ competent cells and placed on ice for $30 \mathrm{~min}$. Cells were heat shocked at $42{ }^{\circ} \mathrm{C}$ for $45 \mathrm{sec}$ followed by $3 \mathrm{~min}$ on ice; then recovered with $500 \mu \mathrm{l}$ of LB medium and incubated for $1 \mathrm{~h}$ at $37^{\circ} \mathrm{C} .50 \mu \mathrm{l}$ of the cell culture were seeded in an agar plate containing ampicillin and incubated $\mathrm{ON}$ at $37^{\circ} \mathrm{C}$. Colonies were picked and grown in $30 \mathrm{ml}$ LB medium to be further used for Maxi preparation of DNA. 


\subsection{Amplification of Plasmid DNA (Maxi Prep)}

Solutions and reagents

\section{$0.5 \mathrm{M}$ EDTA pH $8.0(100 \mathrm{ml})$}

EDTA

$18.62 \mathrm{~g}$

$\mathrm{pH}$ was adjusted with solid $\mathrm{NaOH}$ to 8.0

\section{STE Buffer (100 ml)}

$1 \mathrm{mM}$ EDTA

$0.2 \mathrm{ml} / 0.5 \mathrm{M}$

$25 \%$ Saccharose

$25 \mathrm{~g}$

50 mM Tris- $\mathrm{HCl}$ pH 8.0

$5 \mathrm{ml} / 1 \mathrm{M}$

\section{Triton-Mix (100 ml)}

60 mM EDTA pH 8.0

$12 \mathrm{ml} / 0.5 \mathrm{M}$

$50 \mathrm{mM}$ Tris- $\mathrm{HCl} \mathrm{pH} 8.0$

$5 \mathrm{ml} / 1 \mathrm{M}$

$0.1 \%$ Triton X-100

$0.1 \mathrm{ml}$

PEG solution $(100 \mathrm{ml})$

$1.5 \mathrm{M} \mathrm{NaCl}$

$30 \mathrm{ml} / 5 \mathrm{M}$

30 \% PEG 6000

$30 \mathrm{~g}$

\section{TNE Buffer $(100 \mathrm{ml})$}

$1 \mathrm{mM}$ EDTA

$0.2 \mathrm{ml} / 0.5 \mathrm{M}$

$10 \mathrm{mM} \mathrm{NaCl}$

$0.2 \mathrm{ml} / 5 \mathrm{M}$

10 mM Tris- $\mathrm{HCl}$ pH 8.0

$1 \mathrm{ml} / 1 \mathrm{M}$

\section{TE Buffer (1L)}

1 mM EDTA pH 8.0

$2.0 \mathrm{ml} / 0.5 \mathrm{M}$

10 mM Tris- $\mathrm{HCl}$ pH 8.0

$10 \mathrm{ml} / 1 \mathrm{M}$

\section{Lysozyme $(7 \mathrm{ml})$}

$60 \mathrm{mg} / \mathrm{ml}$ Lysozyme

$420 \mathrm{mg}$

Add to $7 \mathrm{ml}$ with STE buffer 


\section{LB medium (1L) + amp}

\begin{tabular}{ll}
\hline $1 \%(\mathrm{w} / \mathrm{v}) \mathrm{NaCl}$ & $10 \mathrm{~g}$ \\
$1 \%(\mathrm{w} / \mathrm{v})$ Peptone from casein & $10 \mathrm{~g}$ \\
$0.5 \%(\mathrm{w} / \mathrm{v})$ select yeast extract & $5 \mathrm{~g}$
\end{tabular}

Add with distilled water to $1 \mathrm{~L}$

Autoclave $20 \mathrm{~min}$ at $120^{\circ} \mathrm{C}$ at $15 \mathrm{psi}$.

$50 \mu \mathrm{g} / \mathrm{ml}$ Ampicillin

$10 \mathrm{~g}$

$5 \mathrm{~g}$

\section{Ethidium Bromide}

Ethidium bromide

$1 \mathrm{ml}$ of a $50 \mathrm{mg} / \mathrm{ml}$

\section{Maxi-preparation procedure}

After transformation, a preparative ultracentrifugation of bacterial lysate in a cesium chloride $(\mathrm{CsCl})$ gradient was performed. Briefly, one single colony was inoculated into a 30 $\mathrm{ml}$ pre-culture (LB medium containing a final concentration of $50 \mu \mathrm{g} / \mathrm{ml}$ amp) and was grown $\mathrm{ON}$ at $37{ }^{\circ} \mathrm{C}$ with agitation (225 rpm). The pre-culture was used to inoculate $1 \mathrm{~L}$ culture. Cell growth was monitored until it reached an $\mathrm{OD}_{600}$ around 0.6 - 0.8 . Chloroamphenicol was added to the $1 \mathrm{~L}$ culture to get a final concentration of $200 \mathrm{mg} / \mathrm{L}$. After $12 \mathrm{~h}$, the cells were recovered by centrifugation ( $15 \mathrm{~min}$ at $8945 \times \mathrm{g}$ at $4{ }^{\circ} \mathrm{C}$ ). Following steps were carried on ice. The SN was disposed and the pellet was resuspended into $45 \mathrm{ml}$ ice-cold STE buffer. Then $3 \mathrm{ml}$ of a lysozyme solution was added to lyse the bacteria. The lysis time was $20 \mathrm{~min}$, afterwards, $3.6 \mathrm{ml}$ of $0.5 \mathrm{M}$ EDTA were added to stop the lysis. After $5 \mathrm{~min}, 28.8 \mathrm{ml}$ of Triton mix solution were added for the following $30 \mathrm{~min}$, with periodical shaking (every $5 \mathrm{~min}$ ). The mixture was centrifuged ( $1 \mathrm{~h} \mathrm{at}$ $20,000 \times g$ at $4{ }^{\circ} \mathrm{C}$ ) and the $\mathrm{SN}$ was recovered. The SN was incubated for $1 \mathrm{~h}$ with $40 \mathrm{ml}$ of a $30 \%$ PEG solution. After this time, the mixture was centrifuged for $10 \mathrm{~min}$ at 10,000 rpm at $4{ }^{\circ} \mathrm{C}$ and the $\mathrm{SN}$ was discharged. The pellet was air-dried and was resuspended into 10 $\mathrm{ml}$ of TNE buffer. After that, $10.9 \mathrm{~g}$ of $\mathrm{CsCl}$ and $150 \mu \mathrm{l}$ of a $10 \mathrm{mg} / \mathrm{ml}$ ethidium bromide solution were added. The new solution, containing ethidium bromide and $\mathrm{CsCl}$ was pipetted into ultracentrifuge tubes and the tubes were weighted (the difference between the weights did not exceed $0.05 \mathrm{~g}$ ). Samples were centrifuged during $20 \mathrm{~h}$ at 261,600 $\mathrm{g}$ at $20{ }^{\circ} \mathrm{C}$. After ultracentrifugation the band containing plasmid DNA was recovered with a needle and a syringe. The ethidium bromide was washed with isoamylalcohol until the DNA solution was colorless. In order to remove the $\mathrm{CsCl}$, the DNA was dialyzed against 2 $\mathrm{L}$ of TE buffer during $24 \mathrm{~h}$ at $4{ }^{\circ} \mathrm{C}$. Finally, the DNA concentration and purity were measured $\left(O D_{260}, O D{ }_{280}\right)$. Before their use, plasmids were checked by enzymatic restriction. 


\subsection{Eukaryotic cell culture methods}

The procedures for the culturing of eukaryotic cell lines were performed under sterile conditions. All solutions used were sterilized either by filtering or by autoclaving and were pre-warmed before its use (water bath at $37^{\circ} \mathrm{C}$ ). All glassware items were autoclaved. Aseptic procedures were followed before working in the sterile hood (cleaning every surface and material with a $70 \%$ isopropanol solution). Centrifugations were performed at $\mathrm{RT}$ for 2 min at $311 \times g$ (Megafuge 1.0, Heraeus, Hamburg).

\subsubsection{Cell Culture}

\section{Solutions and reagents}

\section{$1 \mathrm{X}$ PBS pH $7.4(1 \mathrm{~L})$}

$\begin{array}{ll}2.5 \mathrm{mM} \mathrm{KCl} & 0.20 \mathrm{~g} \\ 1.5 \mathrm{mM} \mathrm{KH}_{2} \mathrm{PO}_{4} & 0.24 \mathrm{~g} \\ 8.1 \mathrm{mM} \mathrm{Na}_{2} \mathrm{HPO}_{4} & 1.44 \mathrm{~g} \\ 140 \mathrm{mM} \mathrm{NaCl} & 8.00 \mathrm{~g}\end{array}$

Add to $1 \mathrm{~L}$ with distilled water

Adjust $\mathrm{pH}$ to 7.4

Autoclave $20 \mathrm{~min}$ at $120^{\circ} \mathrm{C}$ at $15 \mathrm{psi}$.

\section{Trypsin-EDTA}

Trypsin-EDTA solution

GIBCO BRL, Karlsruhe

\section{Fetal bovine Serum (FBS)}

Fetal bovine serum

GIBCO BRL, Karlsruhe

\section{Penicillin-Streptomycin}

Penicillin Streptomycin solution

GIBCO BRL, Karlsruhe 


\section{RPMI complete}

Fetal bovine serum $\quad 50 \mathrm{ml}$

Penicillin-streptomycin solution $\quad 5 \mathrm{ml}$

RPMI $1640 \quad$ add to $500 \mathrm{ml}$

\section{Cell culture procedure}

InR1G9 monolayers were grown in $30 \mathrm{ml}$ of RPMl culture medium on 15-cm $(150 \times 25$ $\mathrm{mm}$ ) plates and were incubated at $37{ }^{\circ} \mathrm{C}$ in a $5 \% \mathrm{CO}_{2}, 97 \%$ humidity atmosphere (SteriKult Incubator, Labotect GmbH, Göttingen). Cells were grown to $80-90 \%$ confluence and then were propagated following this procedure: plates were rinsed with $10 \mathrm{ml} 1 \mathrm{X}$ PBS solution and then were detached by incubating the cells for $2-3 \mathrm{~min}$ at $37^{\circ} \mathrm{C}$ with $3 \mathrm{ml}$ of trypsin / EDTA solution (GIBCO BRL, Karlsruhe). The plates were shaken to detach the cells. Cells were recovered with $10 \mathrm{ml}$ RPMl medium and were transferred to a $50 \mathrm{ml}$ tube (Blue Max, Falcon, Becton). The suspension was centrifuged and the pellet was resuspended in culture medium to the desired ratio and suspension was plated into new $15-\mathrm{cm}$ plates.

\subsubsection{DEAE-Dextran transfection}

\section{Solutions and reagents}

\section{DEAE-Dextran solution $(30 \mathrm{ml})$}

$60 \mathrm{mg} / \mathrm{ml}$ DEAE-Dextran

Add to $30 \mathrm{ml}$ with distilled water

Filtrate through a $0.45 \mu \mathrm{m}$ syringe filter

\section{TD Buffer $(500 \mathrm{ml})$}
$0.7 \mathrm{mM} \mathrm{K}_{2} \mathrm{HPO}_{4}$
$0.35 \mathrm{ml} / 1 \mathrm{M}$
$5 \mathrm{mM} \mathrm{KCl}$
$2.5 \mathrm{ml} / 1 \mathrm{M}$
$140 \mathrm{mM} \mathrm{NaCl}$
$70 \mathrm{ml} / 1 \mathrm{M}$
25 mM Tris- $\mathrm{HCl}$ pH 7.4
$12.5 \mathrm{ml} / 1 \mathrm{M}$

Autoclave $20 \mathrm{~min}$ at $120^{\circ} \mathrm{C}$ at $15 \mathrm{psi}$. 


\section{X PBS pH $7.4(1 \mathrm{~L})$}

$\begin{array}{ll}2.5 \mathrm{mM} \mathrm{KCl} & 0.20 \mathrm{~g} \\ 1.5 \mathrm{mM} \mathrm{KH}_{2} \mathrm{PO}_{4} & 0.24 \mathrm{~g} \\ 8.1 \mathrm{mM} \mathrm{Na}_{2} \mathrm{HPO}_{4} & 1.44 \mathrm{~g} \\ 140 \mathrm{mM} \mathrm{NaCl} & 8.00 \mathrm{~g}\end{array}$

Add to $1 \mathrm{~L}$ with distilled water

Adjust $\mathrm{pH}$ to 7.4

Autoclave $20 \mathrm{~min}$ at $120^{\circ} \mathrm{C}$ at $15 \mathrm{psi}$.

\section{Trypsin-EDTA}

Trypsin-EDTA solution

GIBCO BRL, Karlsruhe

\section{$\underline{\text { RPMl complete }(500 \mathrm{ml})}$}

Fetal bovine serum $\quad 50 \mathrm{ml}$

Penicillin-streptomycin $5 \mathrm{ml}$

RPMI $1640 \quad 345 \mathrm{ml}$

\section{Transfection procedure}

For transfection, the cells were treated for $3 \min \left(37^{\circ} \mathrm{C}\right)$ with trypsin-EDTA solution and then were recovered with $10 \mathrm{ml}$ complete RPMl (the number of cells was quantified in order use the same amount of cells in each transfection experiment). After centrifugation the medium was disposed and cells were resuspended in $10 \mathrm{ml}$ TD buffer. Another washing step with TD buffer was performed. After centrifugation, cells were resuspended into $1 \mathrm{ml}$ of TD buffer / dish and $5 \mu \mathrm{l} /$ dish of a $60 \mathrm{mg} / \mathrm{ml}$ DEAE-Dextran solution was added. This cell suspension was then mixed with the desired plasmid DNA. $2 \mu \mathrm{g} / \mathrm{of}$ the plasmid pXP2-350GluLuc were used as a reporter plasmid and $0.5 \mu \mathrm{g} /$ dish of the plasmid pGFPtpz-cmv[R] were used for an indirect quantification of transfection efficiency. After 15 min, cells were recovered with complete RPMI medium and centrifuged and an extra washing step with complete RPMI medium was performed. Finally, cells were resuspended with the appropriate volume of complete RPMI medium ( $5 \mathrm{ml} /$ dish). $5 \mathrm{ml}$ of cell suspension were seeded into $60 \times 15 \mathrm{~mm}$ polystyrene tissue culture dishes. Cells were incubated at $37{ }^{\circ} \mathrm{C}$ under $5 \% \mathrm{CO}_{2}$ atmosphere until treatment and harvest were performed. 


\subsection{Cell extract preparation for luciferase and GFP measurements}

\section{Solutions and reagents}

\section{X PBS pH $7.4(1 \mathrm{~L})$}

$\begin{array}{ll}2.5 \mathrm{mM} \mathrm{KCl} & 0.20 \mathrm{~g} \\ 1.5 \mathrm{mM} \mathrm{KH}_{2} \mathrm{PO}_{4} & 0.24 \mathrm{~g} \\ 8.1 \mathrm{mM} \mathrm{Na}_{2} \mathrm{HPO}_{4} & 1.44 \mathrm{~g} \\ 140 \mathrm{mM} \mathrm{NaCl} & 8.00 \mathrm{~g}\end{array}$

Add to $1 \mathrm{~L}$ with distilled water

Adjust $\mathrm{pH}$ to 7.4

Autoclave $20 \mathrm{~min}$ at $120^{\circ} \mathrm{C}$ at $15 \mathrm{psi}$.

\section{Scraping Buffer $(500 \mathrm{ml})$}

$\begin{array}{ll}1 \mathrm{mM} \mathrm{EDTA} & 1 \mathrm{ml} / 0.5 \mathrm{M} \\ 150 \mathrm{mM} \mathrm{NaCl} & 75 \mathrm{ml} / 1 \mathrm{M} \\ 40 \mathrm{mM} \text { Tris HCl pH } 7.5 & 20 \mathrm{ml} / 1 \mathrm{M}\end{array}$

\section{Phosphate buffer pH $7.8(500 \mathrm{ml})$}

Solution 1: $100 \mathrm{mM} \mathrm{K}_{2} \mathrm{HPO}_{4}$

$8.71 \mathrm{~g}$ in $400 \mathrm{ml}$ water

Solution 2: $100 \mathrm{mM} \mathrm{KH}_{2} \mathrm{PO}_{4}$

Adjust the $\mathrm{pH}$ of solution 1 to $\mathrm{pH} 7.8$ with solution 2. Add to $500 \mathrm{ml}$ with distilled water

\section{Phosphate buffer + DTT ( $5 \mathrm{ml})$}

Phosphate buffer $\mathrm{pH} 7.8$

$5 \mathrm{ml}$

1 mM DTT

$5 \mu \mathrm{l} / 1 \mathrm{M}$

\section{Cell extract preparation procedure}

$48 \mathrm{~h}$ after transfection, cells in $60 \times 15 \mathrm{~mm}$ culture dishes were washed once with a $1 \mathrm{X}$ PBS solution. $750 \mu \mathrm{l} /$ dish of scraping buffer were added and the cells were mechanically detached with a scraper. Cells were collected into $1.5 \mathrm{ml}$ tubes (on ice). Extra $750 \mu \mathrm{l} / \mathrm{dish}$ of scrapping buffer were added to the dish and collected into the same tube. After a $5 \mathrm{~min}$ centrifugation step at 5,200 $\times \mathrm{g}$, the supernatant was discarded (using a water pump and 
Pasteur pipette) and $150 \mu \mathrm{l}$ of a phosphate buffer containing DTT were added per tube. Cells were resuspended with a micropipette and immediately 3 freezing-thawing cycles were performed (liq. $\mathrm{N}_{2}$ followed by water bath at $37^{\circ} \mathrm{C}$ ). After a 5 min centrifugation step at 20,800 $\times \mathrm{g}$ the cell extract was ready for the luciferase reporter and for the GFP assays.

\subsection{Luciferase reporter gene assay}

\section{Solutions and reagents}

\section{$200 \mu \mathrm{M}$ ATP $(10 \mathrm{ml})$}

ATP

$1.1 \mathrm{~g}$

Add $9.075 \mathrm{ml}$ distilled water

\section{$1 \mathrm{M}$ DTT $(10 \mathrm{ml})$}

DTT

Add to $10 \mathrm{ml}$ with distilled water

Make $150 \mu \mathrm{l}$ aliquots and freeze at $-20{ }^{\circ} \mathrm{C}$

\section{$180 \mathrm{mM}$ EGTA pH $8.0(100 \mathrm{ml})$}

EGTA

Adjust $\mathrm{pH}$ to 8.0 with solid $\mathrm{NaOH}$

Add to $100 \mathrm{ml}$ with distilled water

\section{$0.5 \mathrm{M}$ Glycylglycine $(100 \mathrm{ml})$}

Glycylglycine

Add to $100 \mathrm{ml}$ with distilled water

\section{Glycylglycine Buffer $(100 \mathrm{ml})$}

4 mM EGTA

25 mM Glycylglycine ( $\mathrm{pH} 7.8)$

$15 \mathrm{mM} \mathrm{MgSO}_{4}$

Adjust $\mathrm{pH}$ to 7.8

Keep at $4{ }^{\circ} \mathrm{C}$
$2.22 \mathrm{ml} / 180 \mathrm{mM}$

$5 \mathrm{ml} / 0.5 \mathrm{M}$

$1.5 \mathrm{ml} / 1 \mathrm{M}$ 


\section{Luciferine}

10 mM DTT

$275 \mathrm{mg}$

Glycylglycine buffer

$178.5 \mathrm{ml}$

1 mM Luciferine

$50 \mathrm{mg}$

Dissolve DTT with glycylglycine buffer on

ice

Add the luciferine under sterile bank (in the dark)

Make $1.4 \mathrm{ml}$ aliquots and freeze at $-80^{\circ} \mathrm{C}$

\section{Luciferase assay mix (LAM) Buffer (for}

\section{5 samples)}

$2 \mathrm{mM} \mathrm{ATP}$

$100 \mu \mathrm{l} / 200 \mu \mathrm{M}$

$1 \mathrm{mM}$ DTT

$10 \mu \mathrm{l} / 1 \mathrm{M}$

$82.4 \%$ (v / v) Glycyglycine buffer

$7.5 \mathrm{ml}$

$16.5 \mathrm{mM}$ Potassium phosphate buffer $\mathrm{pH}$ 7.8

$1.5 \mathrm{ml}$

\section{Luciferase Mix (LM) Buffer (for 25}

\section{samples)}

$10 \mathrm{mM}$ DTT

$56 \mu \mathrm{l}$

Glycyglycine buffer

$5.6 \mathrm{ml}$

$1 \mathrm{mM}$ Luciferine

$1.4 \mathrm{ml}$

\section{$1 \mathrm{M} \mathrm{MgSO}_{4}(100 \mathrm{ml})$}

$\mathrm{MgSO}_{4}$

Add to $100 \mathrm{ml}$ with distilled water

\section{Luciferase assay procedure}

In order to quantify the luciferase activity of the cell extracts, two buffers were prepared previous to the measurement. The first of these buffers was the luciferase assay mix (LAM). $368 \mu \mathrm{l}$ of the LAM buffer were placed into $5 \mathrm{ml}$ plastic tubes $(75 \times 12 \mathrm{~mm}$ diameter, Sarstead, Nümbrecht) and $50 \mu \mathrm{l}$ of the cell extract were added. The samples were briefly vortexed and placed in a luminometer device (AutoLumat LB 953, Berthold Technologies, Bad). The second solution, or luciferase mix (LM) was maintained in the dark and was placed under the automatic dosifier of the luminometer. The machine measures each 
sample within a 20 second interval. The luciferase mix plus $50 \mu \mathrm{l}$ of the phosphate buffer containing DTT was used as a blank.

\subsection{GFP reporter gene assay procedure}

Measurement of GFP was determined using a micro plate reader for GFP (Fusion ${ }^{\mathrm{TM}}$, Packard, Switzerland). $50 \mu \mathrm{l}$ of the cell extract are placed into every other well of a $96 \mathrm{U}$ shaped well plate. $50 \mu \mathrm{l}$ of the phosphate buffer containing DTT were used as a blank. The final GFP values were the result of the subtraction of the GFP measurements from the average of at least three blank values.

\subsection{Treatment of cell cultures}

\section{Solutions and reagents}

\section{$0.9 \% \mathrm{NaCl}$ pH $2.8(100 \mathrm{ml})$}

$\mathrm{NaCl}$

Adjust $\mathrm{pH}$ to 2.8 with $\mathrm{HCl}$

Add to $100 \mathrm{ml}$ with distilled water

\section{$10 \mu \mathrm{M}$ insulin $(50 \mathrm{ml})$}

Porcine insulin $3 \mathrm{mg}$

BSA $100 \mathrm{mg}$

Dissolve $30 \mathrm{mg}$ insulin in $30 \mathrm{ml} 0.9 \% \mathrm{NaCl}$ $\mathrm{pH} 2.8$

Titrate the solution with $1 \mathrm{~N} \mathrm{NaOH}$ to $\mathrm{pH} 6.0$

$-6.4$

Add $100 \mathrm{mg} \mathrm{BSA}$ and let it dissolve (45 min)

Add to $50 \mathrm{ml}$ with $0.9 \% \mathrm{NaCl} \mathrm{pH} 2.8$

Adjust $\mathrm{pH}$ to $7-7.4$

Aliquot and keep at $-20^{\circ} \mathrm{C}$

\section{Various substances treatments and co-transfections}

The insulin-induced inhibition of glucagon gene transcription was assessed not only in the presence of insulin but also in the presence of diverse substances shown to be involved in 
insulin resistance. The following table shows the substances tested, the dose of the treatment or the amount of the transfected plasmid as well as the duration of the treatment or transfection. Treatment of cells with the different substances for either 24 or $46 \mathrm{~h}$ followed the protocol described below. Briefly, for the $24 \mathrm{~h}$ experiments, cells were treated in the same way as in the insulin treatment (section 3.8.1), but right after changing the medium, they were treated with the selected substance. $1 \mathrm{~h}$ later cells were treated with insulin. For the $46 \mathrm{~h}$ experiments, $2 \mathrm{~h}$ after transfection, cells were treated with the compound of interest and $22 \mathrm{~h}$ later, after changing the medium, the cells were treated again with the same substance concentration. $1 \mathrm{~h}$ later, the cells were stimulated with insulin (23 $\mathrm{h}$ insulin treatment). Harvest was always performed $48 \mathrm{~h}$ after transfection.

\begin{tabular}{|c|c|c|}
\hline Compound & Doses & Time of treatment (hr) \\
\hline Insulin & Various & 23 \\
\hline 8BrcAMP & $1 \mathrm{mM}$ & 24,46 \\
\hline Cyclosporin A & $300 \mathrm{nM}$ & 24,46 \\
\hline Dexamethasone & $1 \mu \mathrm{M}$ & 24,46 \\
\hline $\mathrm{H}_{2} \mathrm{O}_{2}$ & $10,30 \mu \mathrm{M}$ & 24 \\
\hline IL-1 $\beta$ & $0.02,0.3,10 \mathrm{ng} / \mathrm{ml}$ & 24 \\
\hline IL-6 & $10 \mathrm{ng} / \mathrm{ml}$ & 24,46 \\
\hline Insulin & $100 \mathrm{nM}$ & 24 \\
\hline Linoleic acid & $0.2 \mathrm{mM}$ & 24 \\
\hline Linolenic acid & $0.2 \mathrm{mM}$ & 24 \\
\hline Oleic acid & $0.4 \mathrm{mM}$ & 24 \\
\hline Palmitic acid & $0.2 \mathrm{mM}$ & 24 \\
\hline $\mathrm{PKB}_{\mathrm{myr}}$ & $2 \mu g$ & 48 \\
\hline $\mathrm{PKB}_{\text {myr }}-\mathrm{K} 179 \mathrm{M}$ & $2 \mu g$ & 48 \\
\hline PPAR $\gamma$ & $1 \mu \mathrm{g}$ & 48 \\
\hline Rosiglitazone & $50 \mu \mathrm{M}$ & $24,46,120$ \\
\hline Stearic acid & $0.2 \mathrm{mM}$ & 24 \\
\hline Tacrolimus (FK506) & $10 \mathrm{nM}$ & 24,46 \\
\hline TNF $\alpha$ & $10 \mathrm{ng} / \mathrm{ml}$ & 24,46 \\
\hline TNF $\alpha$ & $100 \mathrm{ng} / \mathrm{ml}$ & 24 \\
\hline TRB3 & $2 \mu g$ & 48 \\
\hline
\end{tabular}




\subsubsection{Insulin treatment}

InR1G9 cells were transfected following the DEAE-Dextran method (section 3.4.2). The plasmids pXP2-350GluLuc and pGFPtpz-cmv[R] were used as a reporter plasmid and as an indirect quantification of the transfection efficiency, respectively. $24 \mathrm{~h}$ after transfection cells were washed with a $1 \mathrm{X}$ PBS $\mathrm{pH} 7.4$ solution and the medium was replaced with a RPMI medium (GIBCO ${ }^{\mathrm{TM}}$ ) containing $0.5 \%$ bovine serum albumin (BSA) (AppliChem $\mathrm{GmbH}$, Germany), 100 units / $\mathrm{ml}$ penicillin and $100 \mu \mathrm{g} / \mathrm{ml}$ streptomycin (GIBCO ${ }^{\mathrm{TM}}$ ). One $\mathrm{h}$ after changing the medium, cells were treated with a $10 \mu \mathrm{M}$ porcine insulin solution (SIGMA-Aldrich $\mathrm{GmbH}$, Steinheim) to the desired final concentrations $(0,0.01,0.03,0.06$, $0.1,0.3,1,3,10 \mathrm{nM}) .23 \mathrm{~h}$ after insulin treatment cells were harvested and cell extracts were prepared for luciferase and GFP assays as described in the previous section.

\subsubsection{BrCAMP}

Transfected cells were treated with the cell permeable homolog of CAMP, 8BrcAMP. Briefly, $24 \mathrm{~h}$ after transfection cells were washed with PBS, and $3 \mathrm{ml}$ of RPMl medium containing $0.5 \%$ BSA were added per dish; immediately the cells were treated with $1 \mathrm{mM}$ 8BrcAMP. $1 \mathrm{~h}$ later cells were treated with various insulin concentrations. $23 \mathrm{~h}$ after insulin addition, cell lysates were prepared for luciferase and GFP measurements. For the extended treatment with 8BrcAMP, $2 \mathrm{~h}$ after transfection $2 \mathrm{ml}$ of complete RPMI medium were withdrawn from the $5 \mathrm{ml}$ medium contained in the $6-\mathrm{cm}$ dishes, and the cells were treated with $1 \mathrm{mM} 8 \mathrm{BrcAMP}$. $22 \mathrm{~h}$ later, the same procedure as in the short exposure to 8BrcAMP was performed, followed $1 \mathrm{~h}$ later by the insulin treatment. $48 \mathrm{~h}$ after transfection, the cells were harvested and cell lysates were prepared for luciferase and GFP assays.

\subsubsection{Cyclosporin A}

Cyclosporin A and tacrolimus are well known immunosuppressants. For the immunosuppressants experiments, the same approach as in the 8BrcAMP section (section 3.8.2) was performed using $300 \mathrm{nM} \mathrm{CsA}$ either for 24 or for $46 \mathrm{~h}$. 


\subsubsection{Dexamethasone}

In the case of the glucocorticoid dexamethasone, cells were either exposed to $1 \mu \mathrm{M}$ dexamethasone, for 24 or $46 \mathrm{~h}$. The protocol followed to determine whether dexamethasone could influence the insulin-induced inhibition of glucagon gene transcription or glucagon gene transcription itself, was the same followed in section 3.8.2.

\subsubsection{Hydrogen peroxide $\left(\mathrm{H}_{2} \mathrm{O}_{2}\right)$}

The transfection procedure, the washing step and the replacement for RPMI medium containing $0.5 \%$ BSA has been previously described. Immediately after replacing the medium, cells were treated with different hydrogen peroxide concentrations: 10, 33 or 100 $\mu \mathrm{M}$. One $\mathrm{h}$ later, cells were treated with 1 or $3 \mathrm{nM}$ insulin. $23 \mathrm{~h}$ after insulin treatment, cell lysates were prepared for luciferase and GFP measurements.

\subsubsection{Interleukin-1 beta (IL-1ß)}

In the case of this proinflammatory cytokine, various treatments were performed. The procedures for transfection, washing of the cells and for replacement of RPMI medium containing BSA were the same as in the previously described substances. After replacing the medium, cells received a treatment with either 10 or $0.02 \mathrm{ng} / \mathrm{ml} \mathrm{IL}-1 \beta$. For these experiments cells were exposed for $24 \mathrm{~h}$ to this cytokine.

\subsubsection{Interleukin-6 (IL-6)}

Experiments with, interleukin-6, were also performed. Basically the same procedures for transfection, washing of cells, replacement of medium and treatment of the cells as in section 3.8.2 were followed. Two different times for treatments were chosen using $20 \mathrm{ng} /$ $\mathrm{ml}$ IL-6: a $24 \mathrm{~h}$ and a $46 \mathrm{~h}$ treatment.

\subsubsection{Chronic insulin treatment}

Transfection of InR1G9 was performed as previously described. $2 \mathrm{~h}$ after transfection cells were treated with $100 \mathrm{nM}$ insulin. $22 \mathrm{~h}$ later, the cells were washed once with PBS and RPMI medium containing $0.5 \%$ BSA was added to the dishes. Immediately, half of the 
dishes were treated with $100 \mathrm{nM}$ insulin. One h later, all dishes were treated with various insulin concentrations. The same procedures were followed in order to obtain cell lysates (section 3.5) and to quantify luciferase and GFP (sections 3.6 and 3.7).

\subsubsection{Free fatty acids (FFA)}

Different saturation degrees of free fatty acids (FFA) were used: palmitic acid (16:0), stearic acid (18:0), oleic acid $\left(18: 1 \Delta^{9}\right)$, linoleic acid $\left(18: 2, \Delta^{9,12}\right)$ and linolenic acid (18:3, $\left.\Delta^{9,12,15}\right)$. Basically, the same protocol was followed in order to prepare the medium containing the different FFA. One difference for the preparation protocol depended on the presentation of the FFA (powder or oily solution). For those FFA in powder form, the free fatty acids were dissolved in ethanol absolute and were heated for $1-3 \mathrm{~min}$ at approx. $50^{\circ} \mathrm{C}$ to assure their total dissolution. For those free fatty acids in oily solution, the required volume of the FFA was dissolved in ethanol (did not required heating). For each FFA, the effect of the fatty acid in combination with insulin or in combination with the cotransfected plasmid expressing the human peroxisome proliferator-activated receptor gamma (PPAR $\gamma$ ) plus insulin was assessed.

\section{Solutions and reagents}

\section{$5 \%$ fatty acid-free BSA $(10 \mathrm{ml})$}

Fatty acid-free BSA, cell culture tested

Add to $10 \mathrm{ml}$ with $1 \mathrm{X}$ PBS $\mathrm{pH} 7.4$

\section{X PBS pH $7.4(1 \mathrm{~L})$}

$\begin{array}{ll}2.5 \mathrm{mM} \mathrm{KCl} & 0.20 \mathrm{~g} \\ 1.5 \mathrm{mM} \mathrm{KH}_{2} \mathrm{PO}_{4} & 0.24 \mathrm{~g} \\ 8.1 \mathrm{mM} \mathrm{Na}_{2} \mathrm{HPO}_{4} & 1.44 \mathrm{~g} \\ 140 \mathrm{mM} \mathrm{NaCl} & 8.00 \mathrm{~g}\end{array}$

Add to $1 \mathrm{~L}$ with distilled water

Adjust $\mathrm{pH}$ to 7.4 


\section{General procedure for the preparation of the FFA solutions}

Cells were transfected with $2 \mu \mathrm{g} /$ dish of -350 GluLuc and $0.5 \mu \mathrm{g} /$ dish of pGFPtpz$\mathrm{cmv}[\mathrm{R}] .24 \mathrm{~h}$ after transfection the medium was changed to RPMl containing $0.5 \%$ fatty acid-free BSA. The desired amounts of the selected FFA were dissolved into $4 \mathrm{ml}$ absolute ethanol (the volume of the liquid was marked in the beaker). $4 \mathrm{ml}$ of a $20 \mathrm{mM} \mathrm{Na} \mathrm{CO}_{3}$ solution were added. Then the ethanol was evaporated with a gentle $\mathrm{N}_{2}$ flow (approx. $1 \mathrm{~h}$ ) until the mark in the beaker indicated $4 \mathrm{ml}$ again. The solution containing FFA (approx. 4 $\mathrm{ml}$ ) was added drop-wise to $10 \mathrm{ml}$ of the $0.5 \%$ fatty acid-free BSA solution and was gently agitated for $15 \mathrm{~min}$ (50-100 rpm). The $14 \mathrm{ml}$ of FFA-BSA solution were sterile filtrated through a $0.2 \mu \mathrm{m}$ syringe filter to $86 \mathrm{ml}$ of RPMl containing $1.0 \%$ antibiotic solution. The control medium without FFA, as well as the FFA containing medium were incubated $1 \mathrm{~h}$ at $37^{\circ} \mathrm{C}$ under $a \mathrm{CO}_{2}$ atmosphere. The cells were washed once with PBS and the medium was replaced with either medium containing FFA or with the control medium without FFA. $1 \mathrm{~h}$ after changing the medium, cells were treated with increasing insulin concentrations. $48 \mathrm{~h}$ after transfection luciferase and GFP assays were performed as previously described.

\begin{tabular}{|c|c|c|}
\hline Free fatty acid & Formula & MW (g / mol) \\
\hline $0.2 \mathrm{mM}$ palmitic acid & $16: 0$ & $256.42 \mathrm{~g} / \mathrm{mol}$ \\
\hline $0.2 \mathrm{mM}$ stearic acid & $18: 0$ & $284.48 \mathrm{~g} / \mathrm{mol}$ \\
\hline $0.2 \mathrm{mM}$ oleic acid & $18: 1 \Delta^{9}$ & $282.46 \mathrm{~g} / \mathrm{mol}$ \\
\hline $0.4 \mathrm{mM}$ oleic acid & $18: 1 \Delta^{9}$ & $282.46 \mathrm{~g} / \mathrm{mol}$ \\
\hline $0.2 \mathrm{mM}$ linoleic acid & $18: 2, \Delta^{9,12}$ & $280.45 \mathrm{~g} / \mathrm{mol}$ \\
\hline $0.2 \mathrm{mM}$ linolenic acid & $18: 3, \Delta^{9,12,15}$ & $278.44 \mathrm{~g} / \mathrm{mol}$ \\
\hline
\end{tabular}

\subsubsection{PKB $B_{m y r}$ and PKB $B_{m y r}-K 179 M$}

InR1G9 cells were transfected following the DEAE-Dextran method (section 3.4.2). The plasmids pXP2-350GluLuc and pGFPtpz-cmv[R] were used as a reporter plasmid and as an indirect quantification of the transfection efficiency, respectively. In addition to these plasmids, $2 \mu \mathrm{g} /$ dish of either the constitutively active myristylated protein kinase $B$ plasmid, $\mathrm{PKB}_{\mathrm{myr}}$, or of the mutant form of this plasmid, $\mathrm{PKB}_{\mathrm{myr}} \mathrm{K} 179 \mathrm{M}$, were cotransfected. The plasmid Bluescript (Stratagene, La Jolla) was also transfected to maintain a constant 
amount of DNA. $2 \mathrm{~h}$ after transfection some dishes were treated with $100 \mathrm{nM}$ insulin. $22 \mathrm{~h}$ later, the cells were washed and the medium was replaced with RPMI medium containing $0.5 \%$ BSA. Immediately the same dishes previously treated with $100 \mathrm{nM}$ insulin, received again $100 \mathrm{nM}$ insulin (46 $\mathrm{h}$ insulin treatment). $1 \mathrm{~h}$ later, some dishes were treated with 10 $\mathrm{nM}$ insulin (23 $\mathrm{h}$ insulin treatment). Three different groups were present in the experiment: 1) basal (without insulin); 2) $23 \mathrm{~h}$ insulin and 3) $46 \mathrm{~h}$ insulin (Figure 5). Cell lysates for luciferase and GFP were prepared as previously described.

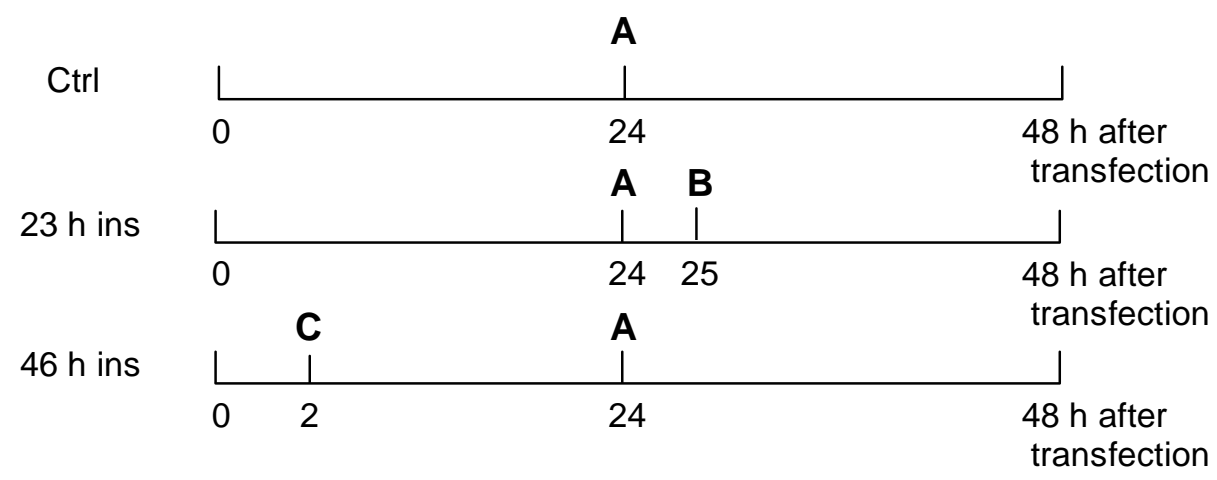

Figure 5. Time line for $\mathrm{PKB}_{\mathrm{myr}}$ and $\mathrm{PKB}_{\mathrm{myr}}-\mathrm{K} 179 \mathrm{M}$ experiments. $\mathrm{A}$ : Change of medium for medium containing $0.5 \%$ BSA; B: treatment with $10 \mathrm{nM}$ insulin $(23 \mathrm{~h})$; C: treatment with $100 \mathrm{nM}$ ins (46 h).

\subsubsection{PPARy}

Cells were transfected with $2 \mu \mathrm{g} /$ dish of -350 GluLuc, $0.5 \mu \mathrm{g} /$ dish of pGFPtpz-cmv[R], 1 $\mu \mathrm{g} /$ dish of human PPAR $(\mathrm{hPPAR} \gamma)$. In order to maintain a constant amount of DNA pBluescript was cotransfected. A group in the absence of PPAR $\gamma$ was also included as a control. $24 \mathrm{~h}$ after transfection the cells were washed once with PBS and the medium was replaced for media containing one of the FFA previously mentioned. $1 \mathrm{~h}$ later, insulin was added to all 4 groups: 1) insulin; 2) insulin + FFA; 3) insulin + PPAR $\gamma$ and 4) insulin + PPAR $\gamma$ + FFA. $23 \mathrm{~h}$ after insulin addition, cells lysates were prepared for luciferase and GFP measurements.

\subsubsection{Rosiglitazone}

The effect of treatment of transfected InR1G9 cells for $46 \mathrm{~h}$ or for $120 \mathrm{~h}$ with rosiglitazone, a synthetic PPARy ligand was studied. Briefly, cells were transfected using the DEAE- 
Dextran method (section 3.4.2). Cells were transfected with $2 \mu \mathrm{g} /$ dish of -350GluLuc, 0.5 $\mu \mathrm{g} /$ dish of pGFPtpz-cmv[R], $1 \mu \mathrm{g} /$ dish of hPPAR $\gamma$. In order to maintain a constant amount of DNA pBluescript was cotransfected. $2 \mathrm{~h}$ after transfection, $50 \mu \mathrm{M}$ rosiglitazone was added to those dishes in which PPAR $\gamma$ was cotransfected. $22 \mathrm{~h}$ later, cells were washed with PBS and the medium was changed to RPMI medium containing $0.5 \%$ BSA. Immediately, cells received a treatment with $50 \mu \mathrm{M}$ rosiglitazone (46 $\mathrm{h}$ treatment). $1 \mathrm{~h}$ later, cells were treated with various insulin concentrations. $48 \mathrm{~h}$ after transfection cell lysates were prepared for luciferase and GFP measurements. An extended rosiglitazone treatment for $120 \mathrm{~h}$ was also performed. Cells were treated with $50 \mu \mathrm{M}$ rosiglitazone one cell passage before transfection was performed ( $72 \mathrm{~h}$ before). Then the same procedure as in the $46 \mathrm{~h}$ rosiglitazone treatment was followed.

\subsubsection{Tacrolimus (FK506)}

Tacrolimus (FK506) is well known immunosuppressant. Studies of the effect of this immunosuppressant were done following the same approach as in the 8BrcAMP experiments (section 3.8.2) using $10 \mathrm{nM} \mathrm{FK506} \mathrm{either} \mathrm{for} 24$ or for $46 \mathrm{~h}$.

\subsubsection{TNF $\alpha$}

Four different types of treatments of transfected InR1G9 cells were performed using TNF $\alpha$. The first three treatments were done in the presence of increasing concentrations of insulin and the last type was performed in the absence of insulin. For the first and second treatment, cells were treated with $10 \mathrm{ng} / \mathrm{ml}$ TNF $\alpha$ for 24 and $46 \mathrm{~h}$, respectively. For the third treatment, cells were treated with $100 \mathrm{ng} / \mathrm{ml} \mathrm{TNF} \alpha$ for $24 \mathrm{~h}$. In the last type of experiments $10 \mathrm{ng} / \mathrm{ml}$ TNF $\alpha$ were added $41 \mathrm{~h}$ after transfection $(7 \mathrm{~h}$ before harvesting). One $\mathrm{h}$ later ( $6 \mathrm{~h}$ before harvesting) the cells were treated with different glucagon gene transcription stimulating agents: Phorbol 12-myristate 13-acetate (TPA) [300 nM], forskolin [10 $\mu \mathrm{M}$ ], potassium chloride $(\mathrm{KCl})[45 \mathrm{mM}$ ] or forskolin plus $\mathrm{KCl}$. All experiments were harvested $48 \mathrm{~h}$ after transfection and luciferase and GFP assays were performed. 


\subsubsection{TRB3}

For these experiments, in addition to $2 \mu \mathrm{g} /$ dish of $-350 \mathrm{GluLuc}$ and $0.5 \mu \mathrm{g} / \mathrm{dish}$ of pGFPtpz-cmv[R], $2 \mu \mathrm{g} /$ dish of pcDNA3FTRB3 and $1 \mu \mathrm{g} /$ dish of the myristylated constitutively active protein kinase $B$ plasmid, $\mathrm{PKB}_{\text {myr }}$, were cotransfected into InR1G9 cells. pBluescript (Stratagene, La Jolla) was also transfected to maintain a constant amount of DNA. $1 \mathrm{~h}$ after changing the medium, for RPMI medium containing $0.5 \%$ BSA, cells were treated with insulin. Cell lysates were prepared $23 \mathrm{~h}$ after insulin treatment for luciferase and GFP measurements.

\subsection{Western Blot}

\section{Solutions and reagents}

\section{Acrylamide Mix (for $100 \mathrm{ml}$ )}

Acrylamide $29.2 \mathrm{~g}$

Bis-acrylamide $0.8 \mathrm{~g}$

Add with distilled water to $100 \mathrm{ml}$

Filtrate through whatman paper

\section{Laemmli loading Buffer (1X) (25 ml)}

$1 \mathrm{mg} / \mathrm{ml}$ Bromophenol blue $0.0125 \mathrm{~g}$

$10 \%$ Glycerol $2 \mathrm{ml}$

$2 \%$ SDS

$62.5 \mathrm{mM}$ Tris $\mathrm{pH} 6.8$ $5 \mathrm{ml} / 10 \%$ SDS solution

Add to $23.75 \mathrm{ml}$

Keep $950 \mu \mathrm{l}$ aliquots at $-20^{\circ} \mathrm{C}$

Thaw before use and add $50 \mu \mathrm{l} \beta$ mercaptoethanol (5\% $\beta$-mercaptoethanol)

\section{Laemmli loading Buffer (4X) (20 ml)}

$1 \mathrm{mg} / \mathrm{ml}$ Bromophenol blue

$$
0.0125 \mathrm{~g}
$$

$40 \%$ Glycerol

$8 \mathrm{ml}$

$8 \%$ SDS

$1.6 \mathrm{~g}$

$250 \mathrm{mM}$ Tris $\mathrm{pH} 6.8$

$5 \mathrm{ml} / 1 \mathrm{M}$ Tris $\mathrm{pH} 6.8$ 
Add to $18 \mathrm{ml}$

Keep $900 \mu \mathrm{l}$ aliquots at $-20^{\circ} \mathrm{C}$

Thaw before use and add $100 \mu \mathrm{l} \beta$ mercaptoethanol (10\% $\beta$-mercaptoethanol)

\section{$1.5 \mathrm{M}$ Tris $\mathrm{pH} 8.8(500 \mathrm{ml})$}

Tris

$90.86 \mathrm{~g}$

Adjust $\mathrm{pH}$ to 8.8

Add with distilled water to $500 \mathrm{ml}$

\section{$0.5 \mathrm{M}$ Tris $\mathrm{pH} 6.8(500 \mathrm{ml})$}

Tris

Adjust $\mathrm{pH}$ to 6.8

Add with distilled water to $500 \mathrm{ml}$

\section{$10 \%(w / v) \operatorname{SDS}(100 \mathrm{ml})$}

SDS

$10 \mathrm{~g}$

Add with distilled water to $100 \mathrm{ml}$

\section{$10 \%$ APS $(10 \mathrm{ml})$}

$0.1 \mathrm{~g} / \mathrm{ml}$ Ammonium persulfate

\section{Lytic Buffer}

CellLytic $^{\mathrm{TM}}$ M Cell Lysis Reagent

SIGMA-Aldrich GmbH, Steinheim

\section{Lytic Buffer + protease inhibitors $(3500$}

\section{Ll)}

$1 \mu \mathrm{g} / \mathrm{ml}$ Leupeptin

$7 \mu \mathrm{l} / 2 \mu \mathrm{M}$

Lytic Buffer SIGMA

$3081.16 \mu \mathrm{l}$

$2 \mathrm{mM} \mathrm{Na}_{3} \mathrm{OV}_{4}$

$35 \mu \mathrm{l} / 200 \mathrm{mM}$

$50 \mathrm{mM} \mathrm{NaF}$

$350 \mu \mathrm{l} / 500 \mathrm{mM}$

400 nM Okadaic acid

$9.33 \mu \mathrm{l} / 150 \mu \mathrm{M}$

$1 \mu \mathrm{g} / \mathrm{ml}$ Pepstatin

$3.5 \mu \mathrm{l} / 5 \mu \mathrm{M}$

$1 \mathrm{mM}$ PMSF

$14 \mu \mathrm{l} / 250 \mathrm{mM}$ 
TEMED

\section{X Tank Buffer $(1 \mathrm{~L})$}

192 mM Glycine

$0.1 \%$ SDS

$25 \mathrm{mM}$ Tris base
Applichem $\mathrm{GmbH}$, Darmstadt

$14.4 \mathrm{~g}$

$10 \mathrm{ml} / 10 \%$ SDS solution

$3 \mathrm{~g}$

\section{Protein marker}

Page Ruler

MBI Fermentas, St. Leon-Rot

\section{Gel concentrations}

\begin{tabular}{|l|c|c|c|c|}
\hline \multicolumn{1}{|c|}{ Substance } & $\mathbf{4 . 0} \%$ & $\mathbf{6 . 0} \%$ & $\mathbf{7 . 5} \%$ & $\mathbf{1 0 . 0} \%$ \\
\hline Acrylamide MIX & $0.67 \mathrm{ml}$ & $2.0 \mathrm{ml}$ & $2.5 \mathrm{ml}$ & $3.33 \mathrm{ml}$ \\
\hline Tris buffer $\mathrm{pH} 8.8$ & - & 2.5 & $2.5 \mathrm{ml}$ & $2.5 \mathrm{ml}$ \\
\hline Tris buffer $\mathrm{pH} 6.8$ & $1.25 \mathrm{ml}$ & - & - & - \\
\hline $10 \%$ SDS & $50 \mu \mathrm{l}$ & $100 \mu \mathrm{l}$ & $100 \mu \mathrm{l}$ & $100 \mu \mathrm{L}$ \\
\hline Water & $3 \mathrm{ml}$ & $5.3 \mathrm{ml}$ & $5 \mathrm{ml}$ & $4 \mathrm{ml}$ \\
\hline $10 \%$ APS & $50 \mu \mathrm{l}$ & $100 \mu \mathrm{l}$ & $100 \mu \mathrm{l}$ & $100 \mu \mathrm{L}$ \\
\hline TEMED & $2.4 \mu \mathrm{l}$ & $8 \mu \mathrm{l}$ & $6 \mu \mathrm{l}$ & $6 \mu \mathrm{l}$ \\
\hline
\end{tabular}

\subsubsection{SDS-PAGE}

Gels were composed of a stacking gel (Tris pH 6.8) and of a resolving gel (Tris pH 8.8). The polyacrylamide concentration in the stacking gel was always $4 \%$ and the polyacrylamide concentration in the resolving gel varied according to the size of the protein to be analyzed. Gels were run under constant current of $20 \mathrm{~mA}$ or $25 \mathrm{~mA}$ during stacking and resolving gel, respectively.

\subsubsection{Western Blot analysis}

For western blotting, the separated proteins coming from the SDS-PAGE gels were transferred to a membrane and were probed with antibodies (primary antibodies) that react specifically with antigenic epitopes displayed by the target protein attached to the membrane. This primary antibody is later on detected by a secondary antibody, which normally contains an attached signaling group such as horseradish peroxidase. This molecule can react with compounds and emit chemiluminescence, which then can be detected by exposing the membrane to a film. 


\subsubsection{Western Blot using semi dry transfer}

\section{$10 \times \operatorname{TBS}(1 \mathrm{~L})$}

$1.5 \mathrm{M} \mathrm{NaCl}$

$80 \mathrm{~g}$

$100 \mathrm{mM}$ Tris

$24.2 \mathrm{~g}$

\section{$1 \mathrm{X}$ TBS / T (1 L)}

$10 \mathrm{mM}$ TBS

$100 \mathrm{ml} / 10 \times$ TBS

$0.1 \%(v / v)$ Tween 20

$1 \mathrm{ml}$

Add with distilled water to $1 \mathrm{~L}$

\section{Buffer A pH $11.3(1 \mathrm{~L})$}

$20 \%$ (v / v) Methanol

$200 \mathrm{ml}$

$300 \mathrm{mM}$ Tris

$36.6 \mathrm{~g}$

Adjust $\mathrm{pH}$ with $\mathrm{HCl}$

Add with distilled water to $1 \mathrm{~L}$

\section{Buffer B pH $10.5(1 \mathrm{~L})$}

$20 \%$ (v/v) Methanol

$200 \mathrm{ml}$

$25 \mathrm{mM}$ Tris

$3.05 \mathrm{~g}$

Adjust $\mathrm{pH}$ with $\mathrm{HCl}$

Add with distilled water to $1 \mathrm{~L}$

\section{Buffer $\mathrm{C}$ pH 9.0, adjusted with boric acid}

\section{(1 L)}

$20 \%$ (v/v) Methanol

$200 \mathrm{ml}$

$25 \mathrm{mM}$ Tris

Adjust $\mathrm{pH}$ with boric acid

Add with distilled water to $1 \mathrm{~L}$

\section{Blocking solution (for $100 \mathrm{ml}$ )}

$5 \%$ Skim Milk

$5 \mathrm{~g}$

Add to $100 \mathrm{ml}$ with $1 \mathrm{X}$ TBS / T 


\section{Primary antibody incubation solution}

(for $25 \mathrm{ml}$ )

$5 \%$ BSA

Add to $25 \mathrm{ml}$ with $1 \mathrm{X}$ TBS / $\mathrm{T}$

\section{ECL western blotting detecting reagents Amersham Biosciences, Freiburg}

After SDS-PAGE was performed, the resolving gel was incubated during 20 min in buffer $\mathrm{C}$ and the nitrocellulose membrane was incubated for $10 \mathrm{~min}$ in buffer $\mathrm{B}$. Proteins were transferred from the gel to the membrane using a semi-dry electroblotting chamber. The transfer conditions were $1 \mathrm{~h} 10 \mathrm{~min}$ at a constant current of $1.2 \mathrm{~mA} / \mathrm{cm}^{2}$. The transference arrangement of the blotting stack was as follows (starting from the cathode- bottom to the anode-top): $2 x$ whatman papers in buffer $A, 2 x$ whatman papers in buffer $B$, membrane in buffer $B$, gel in buffer $C$ and finally $4 x$ whatman papers in buffer $C$. In order to avoid unspecific protein binding, after the transference, the membrane was blocked for $1 \mathrm{~h}$ at $\mathrm{RT}$ in blocking solution under constant rocking. This blocking procedure was performed $\mathrm{ON}$ at $4^{\circ} \mathrm{C}$ for the anti-mouse IR- $\beta$ antibody in order to avoid background. After three washing steps for $5 \mathrm{~min}$ with TBS / T, the required dilution of the primary antibody was added in a 5 \% BSA-TBS / T solution (1: 2,500 for Akt and P-Akt antibodies) or in a $5 \%$ skim milk-TBS / T solution (1: 1,000 for the IR and P-IR antibodies). The membrane was incubated ON with the primary antibody at $4^{\circ} \mathrm{C}$ with gentle rocking. Next day, the membrane was washed three times for 5 min with TBS / T at RT (under rocking). Then the membrane was incubated for $1 \mathrm{~h}$ at RT with the secondary antibody (anti-rabbit horseradish peroxidaseHRP) at 1: 10,000 dilution. After three washing steps of $5 \mathrm{~min}$ with TBS / T, the membrane was ready for protein detection. In order to obtain the luminescence signal, the membrane was incubated for 1 min with a 1:1 mix of ECL reagents $A$ and $B$. The excess of reagents was withdrawn carefully and the membrane was wrapped in saran foil and placed in an exposure cassette. The membrane was exposed for different times to an ultra sensitive film and was developed (one min incubation in developer solution followed by rinsing with water and $1 \mathrm{~min}$ incubation in fixer solution). Then, the film was thoroughly rinsed with water and air-dried. 


\subsubsection{Western Blot using wet transfer}

\section{Solutions and reagents}

\section{$10 \mathrm{X}$ Tris-glycine buffer $(1 \mathrm{~L})$}

$\begin{array}{ll}1.9 \mathrm{M} \text { Glycine } & 144 \mathrm{~g} \\ 250 \mathrm{mM} \text { Tris } & 30.29 \mathrm{~g} \\ \text { Add with distilled water to } 1 \mathrm{~L} & \end{array}$

\section{Transfer buffer $(1.5 \mathrm{~L})$}

$20 \%(\mathrm{v} / \mathrm{v})$ Methanol $300 \mathrm{ml}$

$10 \%$ (v/v) 10X Tris-glycine buffer $\quad 150 \mathrm{ml}$

Add with distilled water to $1.5 \mathrm{~L}$

$\mathrm{pH}$ should be between 8.2 and 8.4

After SDS-PAGE, the $6.0 \%$ resolving gel was incubated during $1 \mathrm{~min}$ in transfer buffer and the nitrocellulose membrane was incubated shortly in water and then for $1 \mathrm{~min}$ in transfer buffer. Proteins were electroblotted from the gel to the membrane using a wet electroblotting chamber. The transfer conditions were $2 \mathrm{~h}$ at a constant current of $4.8 \mathrm{~mA}$ / $\mathrm{cm}^{2}$ (300 mA for a $9 \times 6 \mathrm{~cm}$ membrane) at $4^{\circ} \mathrm{C}$. The transference arrangement of the blotting stack was as follows (the stack was built on the black half of the cassette and then the lid was positioned so that the black side faced the read lead, anode): one $3 \mathrm{~mm}$-thick foam sponge, $1 \mathrm{x}$ whatman paper, membrane, gel, $1 \mathrm{x}$ whatman paper and one $3 \mathrm{~mm}$-thick foam sponge (all these were pre-soaked in transfer buffer and the stack was always maintained wet before it was introduced into the transfer chamber). The chamber was filled up with pre-cooled transfer buffer so that the transfer buffer level was in between the minimum and the maximum levels marked on the chamber. After this transfer procedure, 1 h blocking was performed at RT either in a $5 \%$ milk-TBS / T solution for the IRS membrane or with a $5 \% \operatorname{lgG}$ free-BSA-TBS / T solution for the P-IRS membrane. After three washing steps for 5 min with TBS / T, the required dilution of the primary antibody was added in a $5 \%$ BSA-TBS / T solution (1: 1,000 for IRS antibody) or in a $3 \%$ IgG freeBSA-TBS / T solution (1:1000 P-IRS Tyr 612 antibody). The membranes were incubated $\mathrm{ON}$ with the primary antibody at $4^{\circ} \mathrm{C}$ with gentle rocking. Next day, the membranes were washed three times for $5 \mathrm{~min}$ with TBS / T at RT (under rocking). The membrane was 
incubated for $1 \mathrm{~h}$ at RT with the secondary antibody (anti-rabbit horseradish peroxidase$\mathrm{HRP}$ ) at 1: 10,000 dilution. After three washing steps for $5 \mathrm{~min}$ with TBS / T, the membrane was ready for detection. For the ECL detection, the membrane was exposed for different times to the ultra sensitive film and afterwards was developed as previously described.

\subsubsection{Western blot processing and quantification}

Films were scanned and were transferred to Adobe Photoshop for image processing. Densitometry analysis was performed using a software called Biometra 2.0 (Biometra, Göttingen). Densitometry measurements are based on the intensity of the bands measured by the program, which initially identifies a background pixel number. For the experiments in the present work, densitometry data is reported as percentage of the control band (non-phosphorylated protein or insulin-induced phosphorylated band), as a percentage of the ratio of the insulin receptor (IR) to the glyceraldehyde-3-phosphate dehydrogenase (GAPDH) content or as indicated in each figure legend.

\subsection{Treatment of cells for PKB and Phospho Ser 473 PKB analysis}

\subsubsection{Insulin treatment}

Confluent $150 \mathrm{~mm}$ dishes containing InR1G9 cells were splitted into $60 \mathrm{~mm}$ dishes (one $150 \mathrm{~mm}$ dish to seven $60 \mathrm{~mm}$ dishes). Two h after splitting, some dishes were treated with $100 \mathrm{nM}$ insulin (24 h pre-treatment). $22 \mathrm{~h}$ later the cells were washed with $1 \mathrm{X}$ PBS $\mathrm{pH} 7.4$ and the medium was changed to RPMI medium containing $0.5 \%$ BSA. Some dishes were immediately treated with $10 \mathrm{nM}$ insulin and others received the same insulin concentration after one hour. $10 \mathrm{~min}$ after insulin treatment, cell lysates were prepared.

\subsubsection{IL-1及 treatment}

Confluent $150 \mathrm{~mm}$ dishes containing InR1G9 cells were splitted into $60 \mathrm{~mm}$ dishes (one $150 \mathrm{~mm}$ dish to eight $60 \mathrm{~mm}$ dishes). $24 \mathrm{~h}$ after splitting, cells were washed with 1X PBS and the medium was changed to RPMI medium containing $0.5 \%$ BSA. After this, some

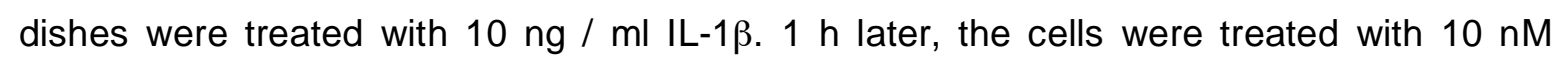
insulin. 10 min after insulin treatment cell lysates were prepared. 


\subsubsection{Preparation of cell lysates for PKB analysis}

Cells were washed with 1X PBS. Immediately $200 \mu$ of hot $1 \mathrm{X}$ Laemmli loading buffer (pre-heated at $95^{\circ} \mathrm{C}$ ) were added per $60 \mathrm{~mm}$ culture dish. Cells were scrapped from the plates and transferred to $1.5 \mathrm{ml}$ eppendorf tubes. Cells were mechanically disrupted 4 to 5 times with a syringe and a needle (27 Gx 3/4", Sterican, B / BRAUN). Cells lysates were placed on a thermoblock at $95^{\circ} \mathrm{C}$ for $5 \mathrm{~min}$. Cells lysates were centrifuged for $1 \mathrm{~min}$ at $13,000 \mathrm{rpm}$ and stored at $-20^{\circ} \mathrm{C}$ until $10 \%$ SDS-PAGE analysis was performed.

\subsection{Treatment of cells for IR and Phospho-IR (Tyr 1150 / 1151) analysis}

Confluent $150 \mathrm{~mm}$ dishes containing InR1G9 cells were splitted into $100 \mathrm{~mm}$ dishes (one $150 \mathrm{~mm}$ dish to three and a half $60 \mathrm{~mm}$ dishes). Two $\mathrm{h}$ after splitting, some dishes were treated with $100 \mathrm{nM}$ insulin (23 $\mathrm{h}$ treatment). $22 \mathrm{~h}$ later the cells were washed with $1 \mathrm{X}$ PBS and the medium was changed to RPMI medium containing $0.5 \%$ BSA and $10 \mathrm{nM}$ insulin was added to the $23 \mathrm{~h}$ group. One $\mathrm{h}$ later, $10 \mathrm{nM}$ insulin was added for $10 \mathrm{~min}$ to the other group. $10 \mathrm{~min}$ after the $10 \mathrm{nM}$ insulin treatment cell lysates were prepared.

\subsection{Treatment of cells for IR disappearance kinetics}

Confluent $150 \mathrm{~mm}$ dishes containing InR1G9 cells were splitted into $100 \mathrm{~mm}$ dishes (one $150 \mathrm{~mm}$ dish to three and a half $60 \mathrm{~mm}$ dishes). Two $\mathrm{h}$ after splitting, the treatment with $100 \mathrm{nM}$ insulin was started. An insulin kinetic study was performed over the following time points: 24 h, 8 h, 4 h, 2 h, 1 h, $30 \mathrm{~min}, 10 \mathrm{~min}, 5 \mathrm{~min}$. Treatments were performed so that all cell lysates could be prepared simultaneously.

\subsection{Treatment of cells for IR recovery kinetics}

Confluent $150 \mathrm{~mm}$ dishes containing InR1G9 cells were splitted into $100 \mathrm{~mm}$ dishes (one $150 \mathrm{~mm}$ dish to three and a half $60 \mathrm{~mm}$ dishes). After $2 \mathrm{~h}$, cells were treated with insulin (24 $\mathrm{h}$ insulin treatment) and after different incubation time points the insulin contained in the media was removed by replacing the medium with either serum containing media (RPMI complete) or with media containing $0.5 \%$ BSA. Recovery periods of 6,12 and $24 \mathrm{~h}$ were performed. 


\subsection{Treatment of cells for proteasomal inhibitor analysis}

Confluent $150 \mathrm{~mm}$ dishes containing InR1G9 cells were splitted into $100 \mathrm{~mm}$ dishes (one $150 \mathrm{~mm}$ dish to three and a half $60 \mathrm{~mm}$ dishes). One and a half hours later, cells were treated with the following proteasomal inhibitors: lactacystin $(5 \mu \mathrm{M})$ or MG132 $(5 \mu \mathrm{M})$ (Calbiochem, Darmstadt). 30 min later, the cells were treated with $100 \mathrm{nM}$ insulin (24 h insulin treatment). $10 \mathrm{~min}$ before harvesting ( $26 \mathrm{~h}$ after plating the cells) the $10 \mathrm{~min}$ insulin group received a treatment with $100 \mathrm{nM}$ insulin.

\subsection{Treatment of cells for protein synthesis inhibition analysis}

Confluent $150 \mathrm{~mm}$ dishes containing InR1G9 cells were splitted into $100 \mathrm{~mm}$ dishes (one $150 \mathrm{~mm}$ dish to three and a half $60 \mathrm{~mm}$ dishes). $24 \mathrm{~h}$ later the cells were washed one time with PBS and medium was replaced for a serum free medium (RPMI containing $0.5 \%$ BSA). $1 \mathrm{~h}$ later, treatment with $50 \mu \mathrm{g} / \mathrm{ml}$ cycloheximide or with $50 \mu \mathrm{g} / \mathrm{ml}$ cycloheximide + $100 \mathrm{nM}$ insulin for the following time points was started: $12 \mathrm{~h}, 8 \mathrm{~h}, 4 \mathrm{~h}, 2, \mathrm{~h}$ and $1 \mathrm{~h}$. Afterwards, cells were lysed and were prepared for electrophoresis and western blotting.

\subsection{Preparation of cell lysates for IR analysis}

Cells were washed with cold PBS and the dishes were placed on iced water. $750 \mu$ l of lytic buffer, containing protease inhibitors, were added per plate and the plates were incubated on ice for 15 minutes. Afterwards, the cells were scraped from the plates and transferred to $1.5 \mathrm{ml}$ tubes. Cells were centrifuged for $15 \mathrm{~min}$ at $13,300 \times \mathrm{g}\left(\right.$ at $\left.4^{\circ} \mathrm{C}\right)$. The supernatants were transferred to clean tubes. Samples for $7.5 \%$ SDS-PAGE were prepared as follows: 1 portion of $4 \mathrm{X}$ Laemmli loading buffer (containing $20 \% \beta$-mercaptoethanol) and 3 portions of sample. The cell lysates containing Laemmli loading buffer were boiled in a water bath for $5 \mathrm{~min}$. 


\subsection{7 $\beta$-arrestin translocation}

\section{Solutions and reagents}

\section{Buffer A pH 7.0 + PMSF}

$10 \mathrm{mM}$ PIPES

$10 \mathrm{mM} \mathrm{KCl}$

$3.0 \mathrm{mM} \mathrm{NaCl}$

$3.5 \mathrm{mM} \mathrm{MgCl}_{2}$

$1.0 \mathrm{mM}$ PMSF

Cytosolic and membrane fractions from InR1G9 cells were obtained following the subfractionation method from Hüttenrauch et al. (2005). The obtained cytosolic and membrane fractions were submitted to immunoblotting. In brief, InR1G9 cells were treated with $100 \mathrm{nM}$ insulin for 3,10 or $30 \mathrm{~min}$ at $37^{\circ} \mathrm{C}$. After disposal of the culture medium, cells were kept on ice and $3 \mathrm{ml}$ of buffer A containing protease inhibitors was added to the cells. Cells were mechanically detached by scraping. After sonication and centrifugation (1000 $x$ $g$ for $20 \mathrm{~min}$ ), the supernatant was loaded onto a discontinuous sucrose gradient and centrifuged for $2 \mathrm{~h}$ at $160,000 \times g\left(4^{\circ} \mathrm{C}\right)$. The $35 / 50 \%$ sucrose interphase (membrane fraction) was collected, diluted in $3 \mathrm{ml}$ of buffer $\mathrm{A}$ and re-centrifuged for $15 \mathrm{~min}$ at 160,000 $x \mathrm{~g}\left(4^{\circ} \mathrm{C}\right)$. The pellet was resuspended in lysis buffer and equal amounts of samples (approx. $25 \mu \mathrm{g}$ ) were separated by $10 \%$ SDS-PAGE. Proteins were transferred to nitrocellulose membranes, and non-specific binding sites were blocked by incubation for 30 min with a $4 \%$ nonfat dry milk in TBS / T. $\beta$-arrestin 1 and $\beta$-arrestin 2 were detected using the monoclonal antibody 21-B1 $(10 \mu \mathrm{g} / \mathrm{ml})$ and horseradish peroxidase labeled secondary antibodies (1:2000) (Hüttenrauch et al., 2005).

\subsection{Treatment of cells for lysosomal degradation inhibitors analysis}

\section{Solutions and reagents}

\section{$1 \mathrm{M}$ Ammonium chloride $(5 \mathrm{ml})$}

Ammonium chloride

Add with distilled water to $5 \mathrm{ml}$

Sterile filtrate through $0.2 \mu \mathrm{m}$ filter 


\section{$200 \mathrm{mM}$ Chloroquine $(5 \mathrm{ml})$}

Chloroquine

$0.3198 \mathrm{~g}$

Add with distilled water to $5 \mathrm{ml}$

Sterile filtrate through $0.2 \mu \mathrm{m}$ filter

Confluent $150 \mathrm{~mm}$ dishes containing InR1G9 cells were splitted into $100 \mathrm{~mm}$ dishes (one $150 \mathrm{~mm}$ dish to three and a half $60 \mathrm{~mm}$ dishes). $1 \mathrm{~h}$ later the cells were treated with chloroquine to a final concentration of $200 \mu \mathrm{M}$ or with ammonium chloride to a final concentration of $10 \mathrm{mM}$ ( $25 \mathrm{~h}$ treatments). $1 \mathrm{~h}$ later $100 \mathrm{nM}$ insulin was added to the cells (24 $\mathrm{h}$ insulin group). $15 \mathrm{~h}$ later, other cell dishes were treated with the same concentrations of chloroquine and ammonium chloride ( $9 \mathrm{~h}$ treatment). $1 \mathrm{~h}$ later, the cells were treated with $100 \mathrm{nM}$ insulin ( $8 \mathrm{~h}$ insulin group). After $8 \mathrm{~h}$, cell lysates were prepared as describe for the insulin receptor cell lysates and were analyzed by immunoblot using an antibody against insulin receptor beta (mouse).

\subsection{Treatment of cells for IRS-1 and Phosho-IRS-1 (Tyr 612) analysis}

Confluent $150 \mathrm{~mm}$ dishes containing InR1G9 cells were splitted into $100 \mathrm{~mm}$ dishes (one $150 \mathrm{~mm}$ dish to three $60 \mathrm{~mm}$ dishes). Two h after splitting, one dish was treated with 100 $\mathrm{nM}$ insulin (23 hr treatment). $23 \mathrm{~h}$ later, another dish was treated with $100 \mathrm{nM}$ insulin (10 min treatment). After $10 \mathrm{~min}$, cell lysates were prepared as previously described for the insulin receptor lysates. 


\section{RESULTS}

\subsection{Effect of substances known to induce insulin resistance in other tissues, on the inhibition of glucagon gene transcription in a-cells}

\subsubsection{Insulin dose response curve}

Insulin acts directly on alpha $(\alpha)$ cells of the islets of Langerhans to inhibit the secretion and biosynthesis of glucagon, as well as glucagon gene transcription (Philippe, 1989). The insulin-induced inhibition of glucagon gene transcription in the $\alpha$-cell line InR1G9 was corroborated (Grzeskowiak et al., 2000; Schinner et al., 2005a) by performing transfection experiments with a reporter plasmid containing a luciferase gene under the control of 350 base pairs [from -350 to +58 ] of the rat glucagon promoter. As a control for transfection efficiency, a plasmid coding for the green fluorescent protein under control of the cytomegalovirus promoter (pGFPtpz-cmv[R]) was co-transfected. $24 \mathrm{~h}$ after transfection cells were treated for the following $23 \mathrm{~h}$ with increasing insulin concentrations. Two days after transfection, cell lysates were prepared for analysis. In the lysates, the luciferase activity and GFP fluorescence were measured. Luciferase activity is shown relative to GFP activity. The results in Figure 6 illustrate an insulin dose response curve. This figure shows that insulin inhibited glucagon gene transcription in a dose-dependent fashion. The maximal inhibition reached by insulin treatment was $50 \%$ with an insulin inhibitory concentration ( $\left.\mathrm{IC}_{50}\right)$ of $0.37 \mathrm{nM}$ (Figure 6, Tables 1 and 2). 


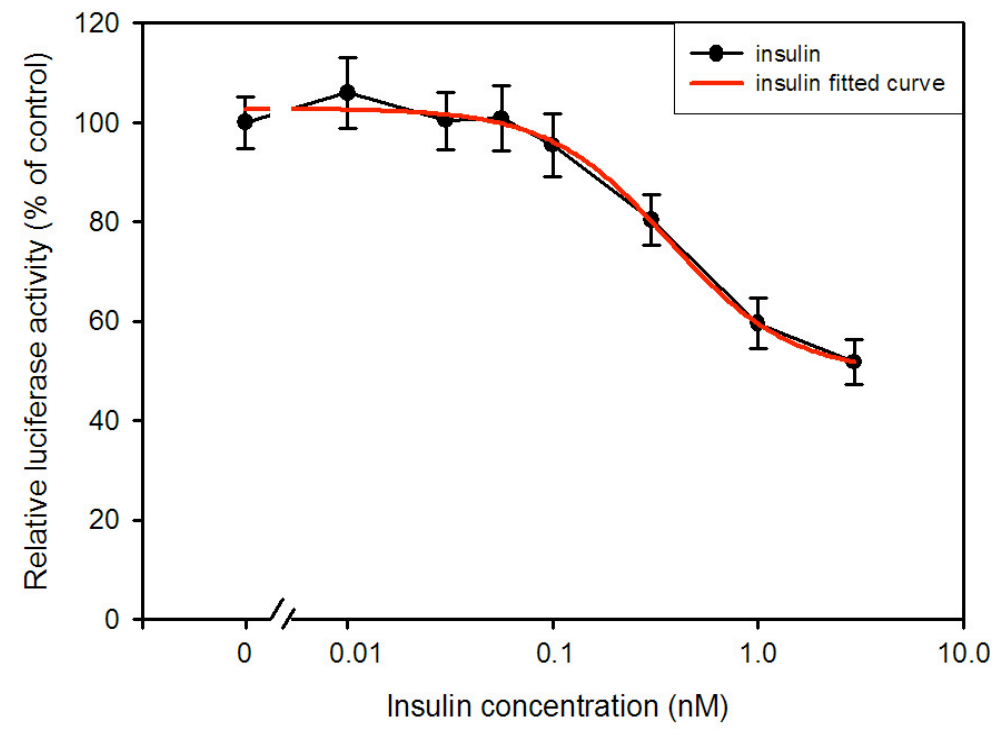

Figure 6. Insulin dose-dependently inhibits glucagon gene transcription. InR1G9 cells were transfected with $2.0 \mu \mathrm{g} /$ dish of the $-350 \mathrm{GluLuc}$ reporter plasmid and $0.5 \mu \mathrm{g} /$ dish of the pGFPtpz$\mathrm{cmv}[\mathrm{R}]$ plasmid. $24 \mathrm{~h}$ after transfection, cells were washed with PBS and the medium was replaced with a medium containing $0.5 \%$ BSA. $1 \mathrm{~h}$ later, cells were treated with increasing insulin concentrations. Values were normalized to the untreated group. Values show the mean $+/-$ SEM of five independent experiments performed in duplicate.

After the generation of an insulin dose-response curve, the effect of different substances, reported to induce insulin resistance in other tissues, on the inhibition by insulin of glucagon gene transcription was examined.

\subsubsection{Effect of tumor necrosis factor alpha}

Three different experiments were performed using this adipokine: two treatments with 10 $\mathrm{ng} / \mathrm{ml} \mathrm{TNF} \alpha$, either for 24 or for $46 \mathrm{~h}$ and one $24 \mathrm{~h}$ treatment with a 10 -fold higher TNF $\alpha$ concentration. Treatment for $24 \mathrm{~h}$ with $10 \mathrm{ng} / \mathrm{ml}$ TNF $\alpha$ inhibited basal glucagon gene transcription only by $7 \%$, which was a non-significant difference with respect to the control group (Table 1, Figure 7 A). The same treatment increased 1.1-fold the insulin-induced inhibition of glucagon gene transcription. The $\mathrm{IC}_{50}$ value was increased by $0.32 \mathrm{nM}$ (Table 2, Figure 7 B). Under these conditions TNF $\alpha$ did not have a significant effect on either basal glucagon gene transcription or on the insulin-induced inhibition of this gene. Increasing the time of TNF $\alpha$ treatment to $46 \mathrm{~h}$ did not modify any of the studied parameters (Figures $8 \mathrm{~A}$ and $8 \mathrm{~B}$ ). A $24 \mathrm{~h}$ treatment of the cells with $100 \mathrm{ng} / \mathrm{ml} \mathrm{TNF} \alpha$ inhibited basal glucagon gene transcription by $23 \%(p<0.001)$ (Table 1, Figure 9 A). In the 
presence of insulin, the $100 \mathrm{ng} / \mathrm{ml}$ TNF $\alpha$ concentration augmented 1.2-fold the insulin maximal effect (not significant) (Table 2, Figure 9 B).

\subsubsection{Interleukin 6}

The effect of different treatments with the adipokine interleukin 6 (IL-6) was also assessed in transfected InR1G9 cells. The results of treatment with IL-6 for $24 \mathrm{~h}$ showed a 1.2-fold activation of basal glucagon gene transcription (Table 1, Figure $10 \mathrm{~A}$ ). This treatment did not present an effect on the insulin-induced inhibition of glucagon gene transcription (Table 2, Figure $10 \mathrm{~B}$ ). Extending IL-6 treatment to $46 \mathrm{~h}$ did not modify basal glucagon gene transcription (Table 1, Figure $11 \mathrm{~A}$ ) or the insulin-induced inhibition of glucagon gene transcription (Table 2, Figure $11 \mathrm{~B}$ ).

\subsubsection{Interleukin 1-beta}

Treatment of cells with $10 \mathrm{ng} / \mathrm{ml}$ interleukin 1-beta (IL-1 $\beta$ ) decreased basal glucagon gene transcription by $75 \%$ (Table 1 , Figure $12 \mathrm{~A}$ ). IL-1 $\beta$ in combination with increasing insulin concentrations reversed the insulin-induced inhibition of glucagon gene transcription by $73 \%$. The $\mathrm{IC}_{50}$ value for the IL-1 $\beta$ treated group was decreased by 0.17 $\mathrm{nM}$ with respect to the control group (Table 2, Figure $12 \mathrm{~B}$ ). Another insulin dose-response curve in the presence of $0.02 \mathrm{ng} / \mathrm{ml} \mathrm{IL}-1 \beta$ was performed (Figure 13, A and B). The results showed that this IL-1 $\beta$ threshold concentration did not influence basal glucagon gene transcription or the insulin-mediated inhibition of this gene (Figure 13). 


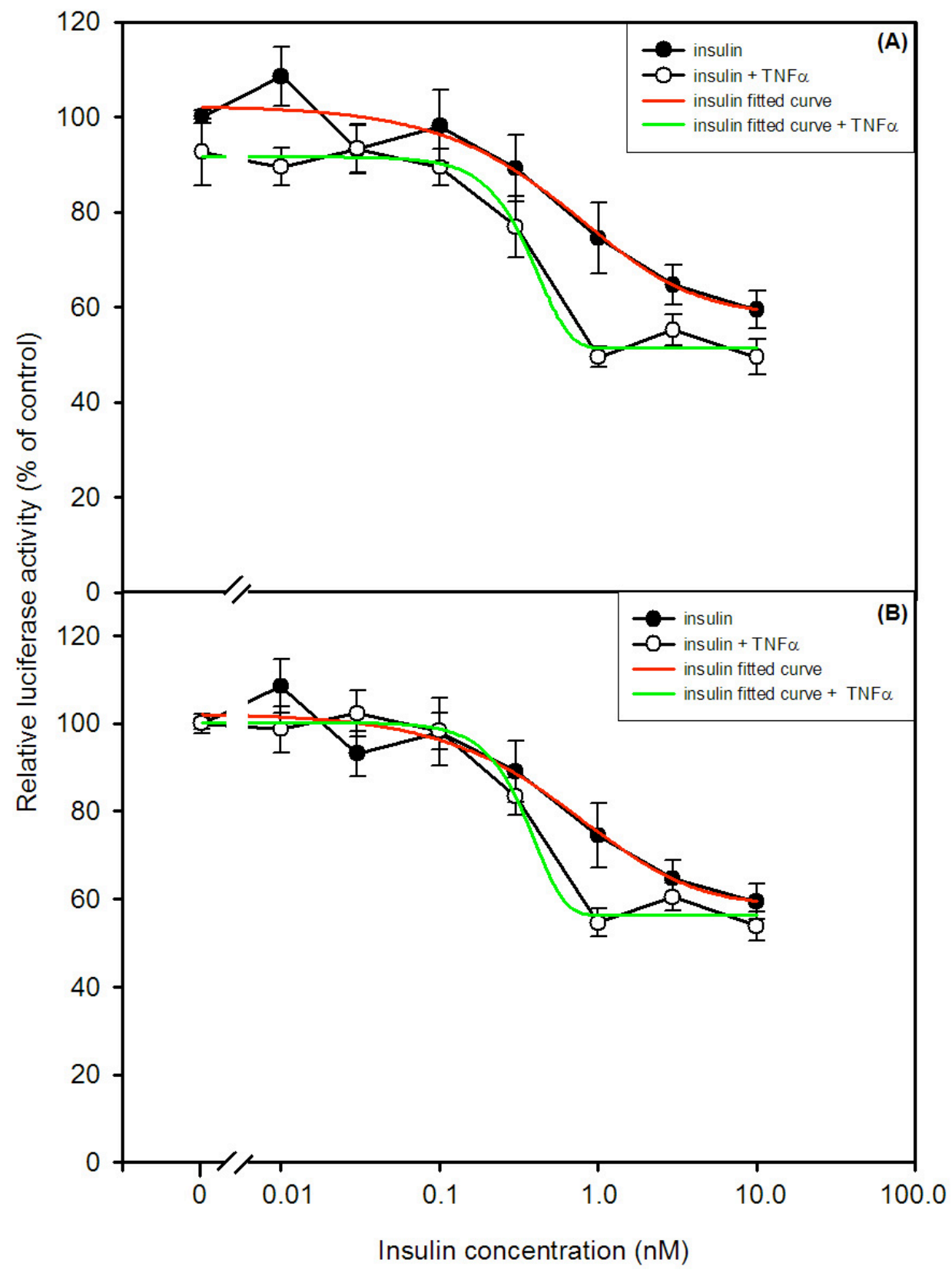

Figure 7. Effect of $24 \mathrm{~h}$ treatment with TNFa $(10 \mathrm{ng} / \mathrm{ml})$ on basal and insulin inducedinhibition of glucagon gene transcription. InR1G9 cells were transfected with $2.0 \mu \mathrm{g} / \mathrm{dish}$ of the -350GluLuc reporter plasmid and $0.5 \mu \mathrm{g} /$ dish of the pGFPtpz-cmv[R] plasmid. $24 \mathrm{~h}$ after transfection, cells were washed with PBS and the medium was replaced with a medium containing $0.5 \%$ BSA. Immediately, $10 \mathrm{ng} / \mathrm{ml} \mathrm{TNF} \alpha$ was added to the cells. $1 \mathrm{~h}$ later, cells were treated with increasing insulin concentrations. $48 \mathrm{~h}$ after transfection cells were harvested and luciferase and GFP activities were measured. A) Values were normalized to the untreated group (no insulin, no $T N F \alpha$ ). B) Values were normalized to the respective group not treated with insulin. Values show the mean + / - SEM of four independent experiments performed in duplicate. 


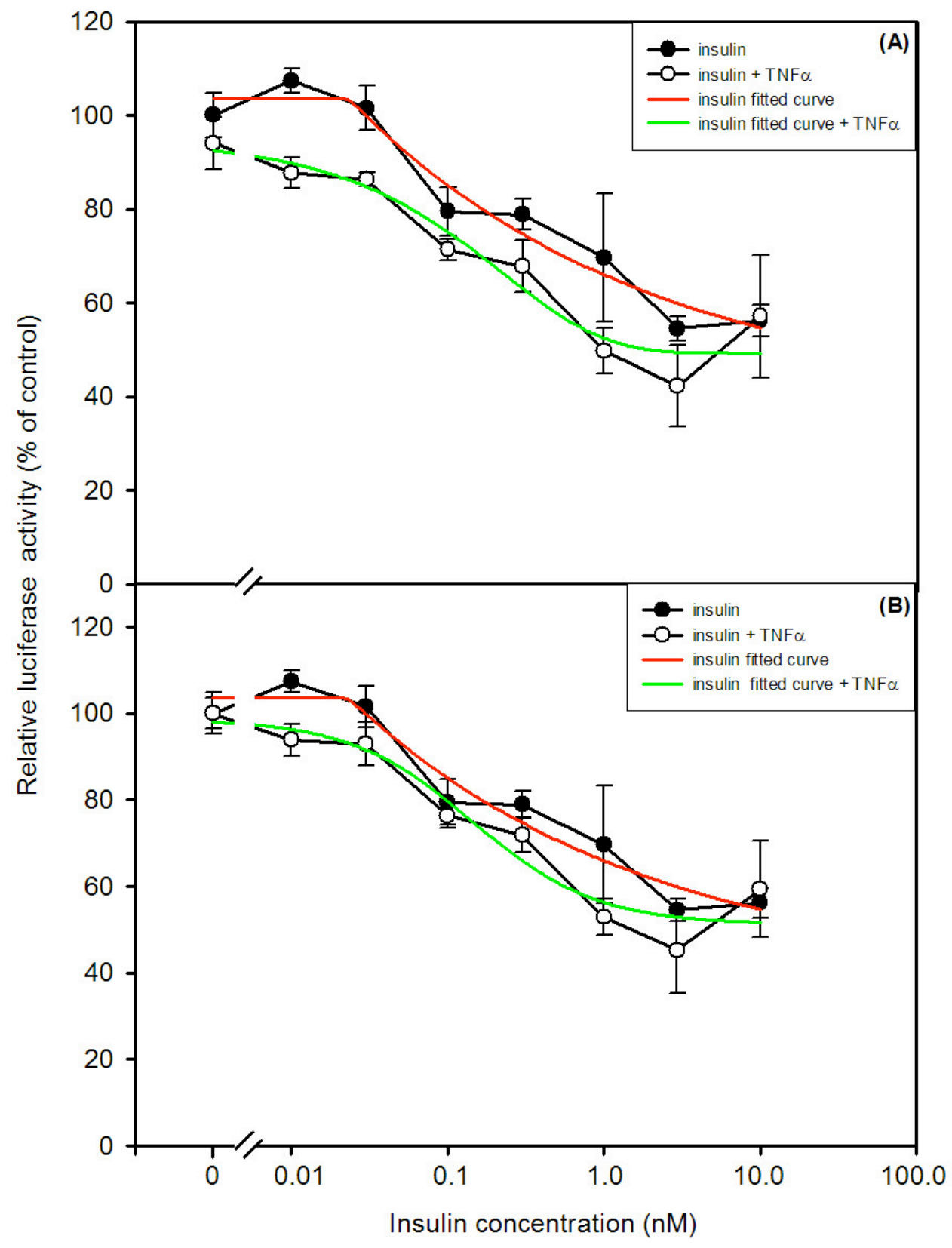

Figure 8. Effect of $46 \mathrm{~h}$ treatment with TNFa $(10 \mathrm{ng} / \mathrm{ml})$ on basal and insulin inducedinhibition of glucagon gene transcription. InR1G9 cells were transfected with $2.0 \mu \mathrm{g} / \mathrm{dish}$ of the -350GluLuc reporter plasmid and $0.5 \mu \mathrm{g} /$ dish of the pGFPtpz-cmv[R] plasmid. $2 \mathrm{~h}$ after transfection, cells were treated with $10 \mathrm{ng} / \mathrm{ml} \mathrm{TNF} \alpha .20 \mathrm{~h}$ later, cells were washed with PBS and the medium was replaced with a medium containing $0.5 \%$ BSA. Immediately, $10 \mathrm{ng} / \mathrm{ml} \mathrm{TNF} \alpha$ was added to the cells. $1 \mathrm{~h}$ later, cells were treated with increasing insulin concentrations. $48 \mathrm{~h}$ after transfection, luciferase and GFP activities were measured. A) Values were normalized to the untreated group (no insulin, no TNF $\alpha$ ). B) Values were normalized to the respective group not treated with insulin. Values show the mean $+/$ - SEM of three independent experiments performed in duplicate. 


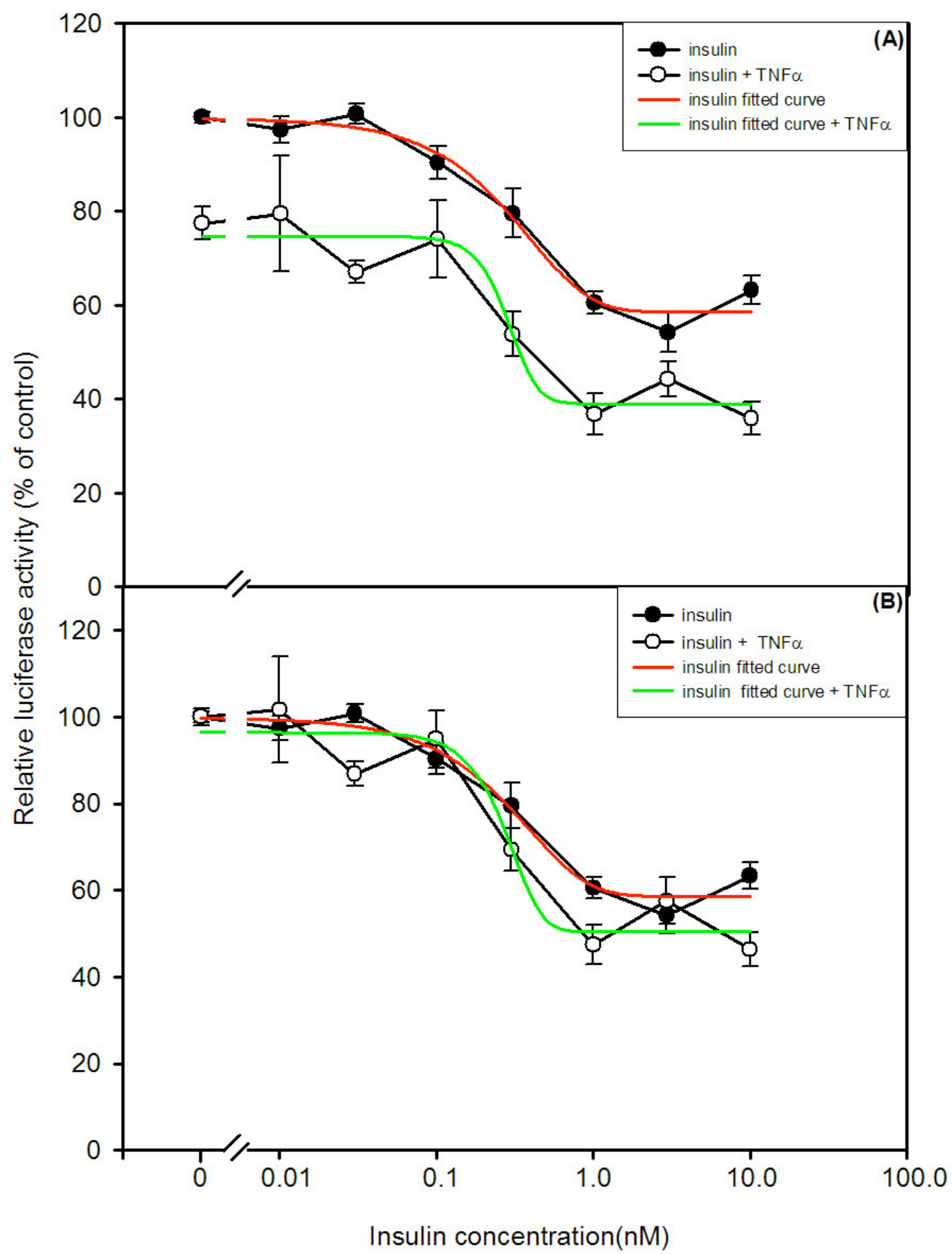

Figure 9. Effect of $24 \mathrm{~h}$ treatment with TNFa $(100 \mathrm{ng} / \mathrm{ml})$ on basal and insulin inducedinhibition of glucagon gene transcription. InR1G9 cells were transfected with $2.0 \mu \mathrm{g} / \mathrm{dish}$ of the -350GluLuc reporter plasmid and $0.5 \mu \mathrm{g} /$ dish of the pGFPtpz-cmv[R] plasmid. $24 \mathrm{~h}$ after transfection, cells were washed with PBS and the medium was replaced with a medium containing $0.5 \%$ BSA. Immediately, $100 \mathrm{ng} / \mathrm{ml}$ TNF $\alpha$ was added to the cells. $1 \mathrm{~h}$ later, cells were treated with increasing insulin concentrations. $48 \mathrm{~h}$ after transfection cells were harvested and luciferase and GFP activities were measured. A) Values were normalized to the untreated group (no insulin, no $T N F \alpha$ ). B) Values were normalized to the respective group not treated with insulin. Values show the mean $+/$ - SEM of two independent experiments performed in duplicate. 


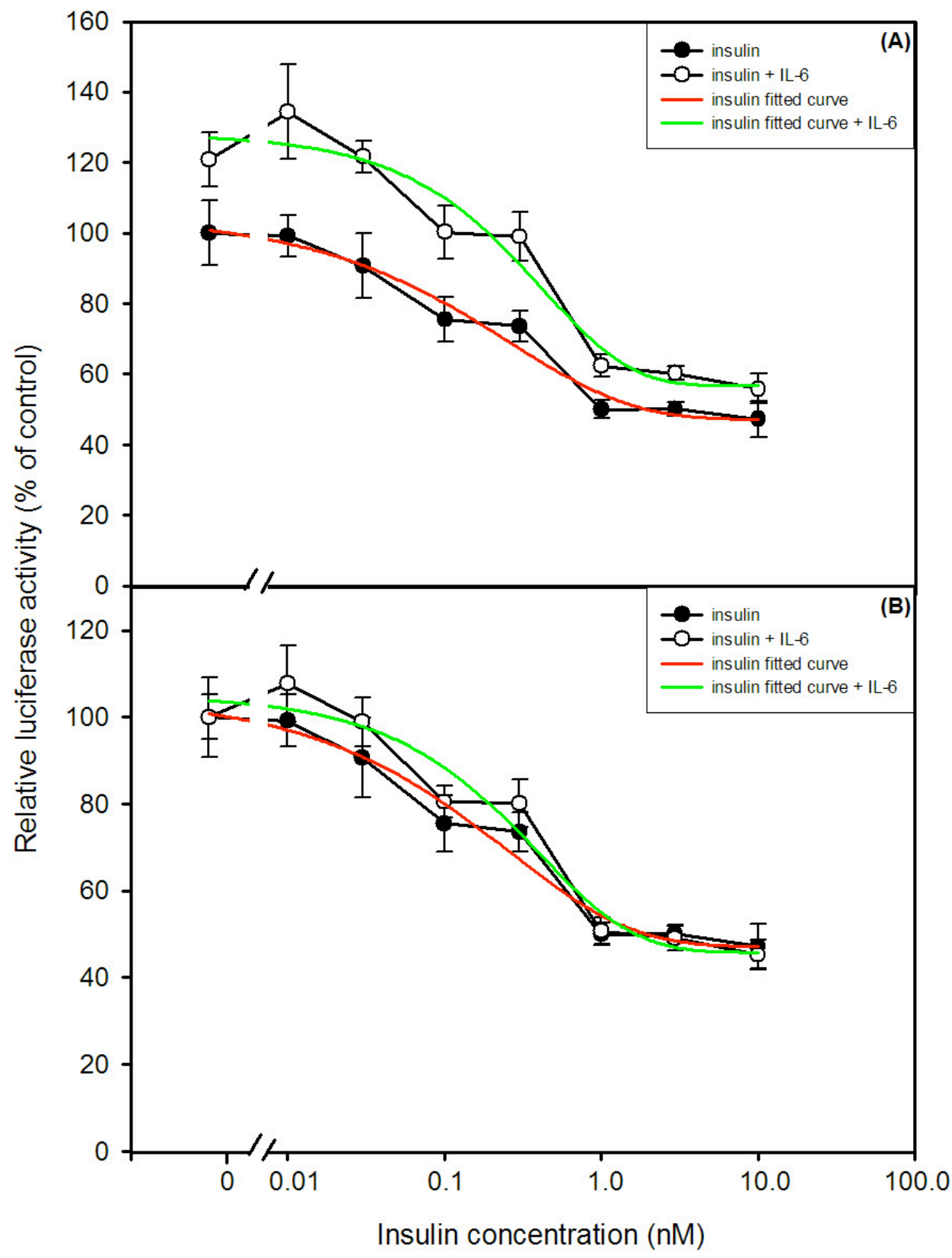

Figure 10. Effect of $24 \mathrm{~h}$ treatment with interleukin $6(20 \mathrm{ng} / \mathrm{ml})$ on basal and insulin induced-inhibition of glucagon gene transcription. InR1G9 cells were transfected with $2.0 \mu \mathrm{g} /$ dish of the $-350 \mathrm{GluLuc}$ reporter plasmid and $0.5 \mu \mathrm{g} /$ dish of the pGFPtpz-cmv[R] plasmid. $24 \mathrm{~h}$ after transfection, cells were washed with PBS and the medium was replaced with a medium containing $0.5 \%$ BSA. Immediately, $20 \mathrm{ng} / \mathrm{ml} \mathrm{IL-} 6$ was added to the cells. $1 \mathrm{~h}$ later, cells were treated with increasing insulin concentrations. $48 \mathrm{~h}$ after transfection cells were harvested and luciferase and GFP activities were measured. A) Values were normalized to the untreated group (no insulin, no IL-6). B) Values were normalized to the respective group not treated with insulin. Values show the mean $+/$ - SEM of three independent experiments performed in duplicate. 


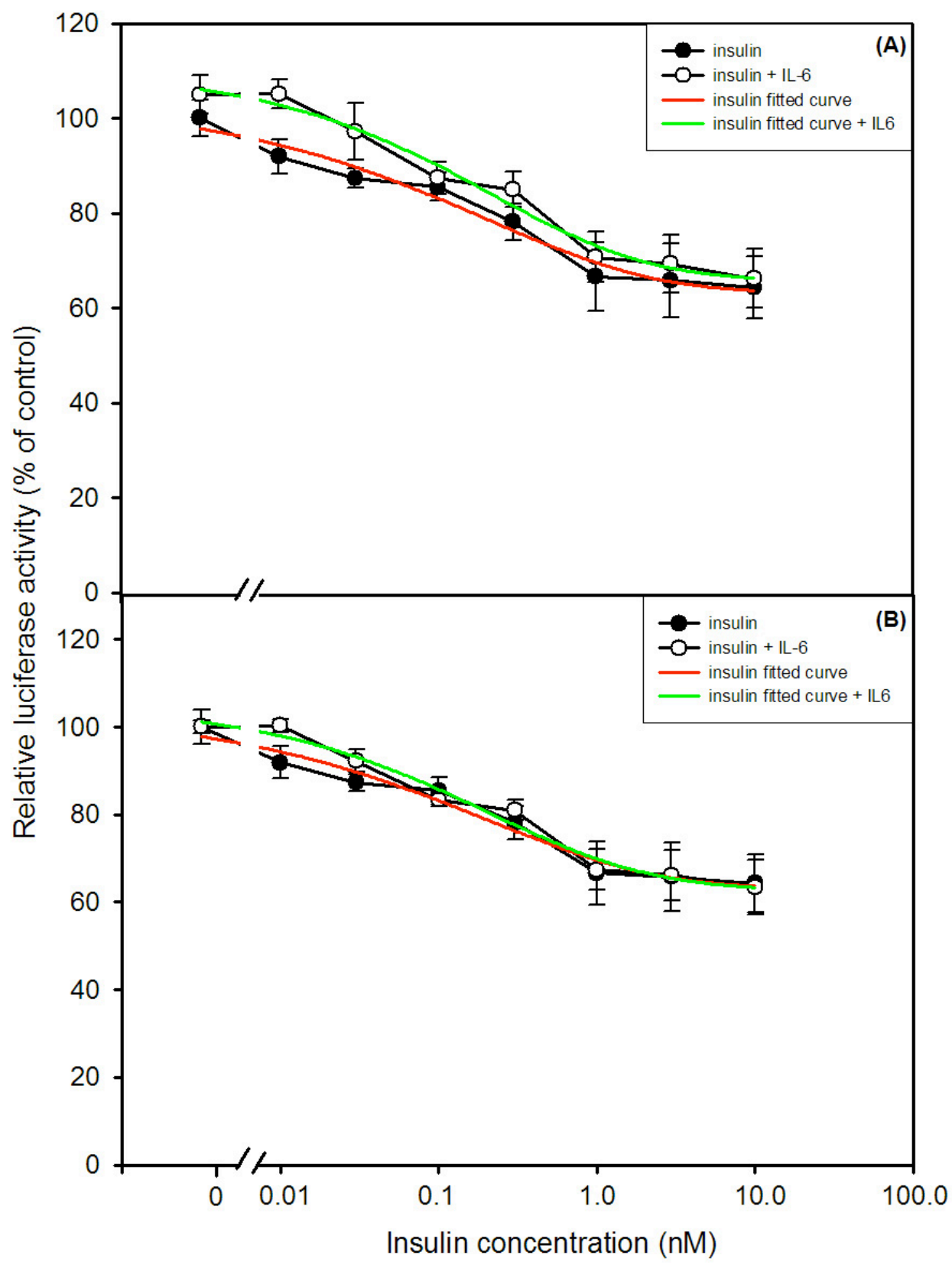

Figure 11. Effect of $46 \mathrm{~h}$ treatment with interleukin $6(20 \mathrm{ng} / \mathrm{ml})$ on basal and insulin induced-inhibition of glucagon gene transcription. InR1G9 cells were transfected with $2.0 \mu \mathrm{g} /$ dish of the $-350 \mathrm{GluLuc}$ reporter plasmid and $0.5 \mu \mathrm{g} /$ dish of the pGFPtpz-cmv[R] plasmid. $2 \mathrm{~h}$ after transfection, cells were treated with $20 \mathrm{ng} / \mathrm{ml}$ IL-6. $20 \mathrm{~h}$ later, cells were washed with PBS and the medium was replaced with a medium containing $0.5 \%$ BSA. Immediately, $20 \mathrm{ng} / \mathrm{ml} \mathrm{IL-6}$ was added to the cells. $1 \mathrm{~h}$ later, cells were treated with increasing insulin concentrations. $48 \mathrm{~h}$ after transfection cells were harvested and luciferase and GFP activities were measured. A) Values were normalized to the untreated group (no insulin, no IL-6). B) Values were normalized to the respective group not treated with insulin. Values show the mean + / - SEM of three independent experiments performed in duplicate. 


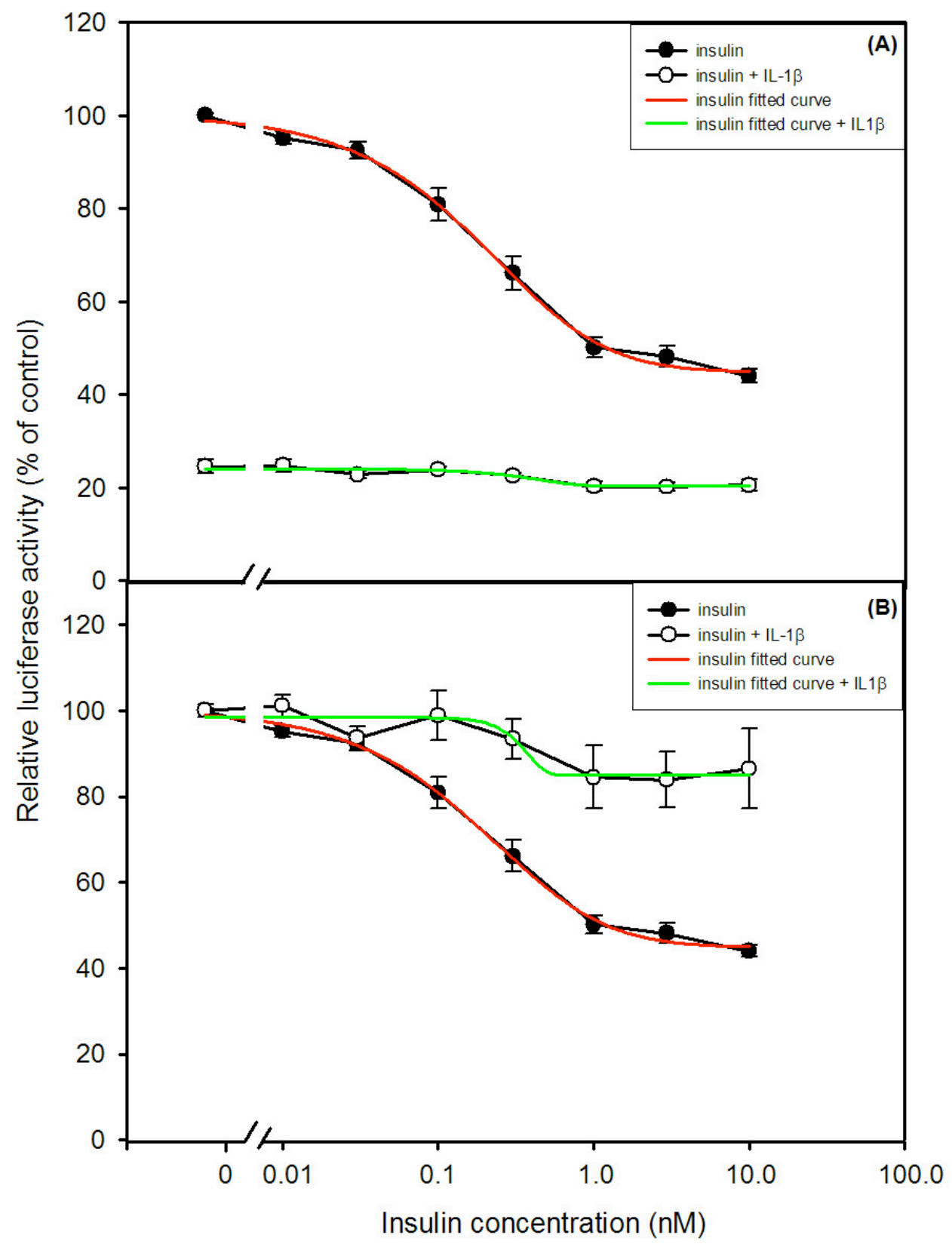

Figure 12. Effect of $24 \mathrm{~h}$ treatment with interleukin 1-beta $(10 \mathrm{ng} / \mathrm{ml})$ on basal and insulin induced-inhibition of glucagon gene transcription. InR1G9 cells were transfected with $2.0 \mu \mathrm{g} /$ dish of the $-350 \mathrm{GluLuc}$ reporter plasmid and $0.5 \mu \mathrm{g} /$ dish of the pGFPtpz-cmv[R] plasmid. $24 \mathrm{~h}$ after transfection, cells were washed with PBS and the medium was replaced with a medium containing $0.5 \%$ BSA. Immediately, $10 \mathrm{ng} / \mathrm{ml} \mathrm{IL-1 \beta}$ was added to the cells. $1 \mathrm{~h}$ later, cells were treated with increasing insulin concentrations. $48 \mathrm{~h}$ after transfection cells were harvested and luciferase and GFP activities were measured. A) Values were normalized to the untreated group (no insulin, no IL-1 $\beta$ ). B) Values were normalized to the respective group not treated with insulin. Values show the mean + / - SEM of three independent experiments performed in duplicate. 


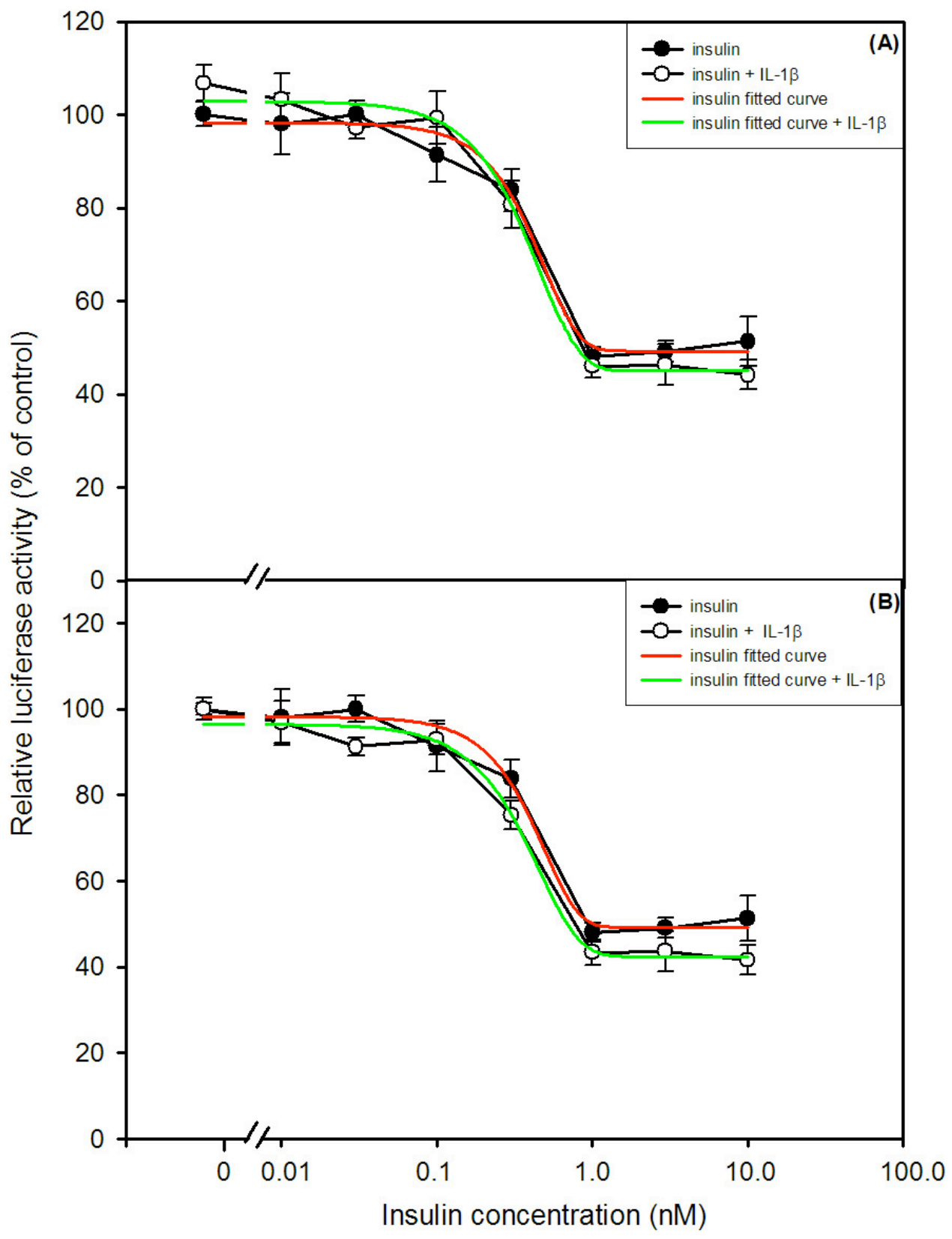

Figure 13. Effect of $24 \mathrm{~h}$ treatment with interleukin 1-beta $(0.02 \mathrm{ng} / \mathrm{ml})$ on basal and insulin induced-inhibition of glucagon gene transcription. InR1G9 cells were transfected with $2.0 \mu \mathrm{g} /$ dish of the $-350 \mathrm{GluLuc}$ reporter plasmid and $0.5 \mu \mathrm{g} /$ dish of the pGFPtpz-cmv[R] plasmid. $24 \mathrm{~h}$ after transfection, cells were washed with PBS and the medium was replaced with a medium containing $0.5 \%$ BSA. Immediately, $0.02 \mathrm{ng} / \mathrm{ml} \mathrm{IL-1} \beta$ was added to the cells. $1 \mathrm{~h}$ later, cells were treated with increasing insulin concentrations. $48 \mathrm{~h}$ after transfection cells were harvested and luciferase and GFP activities were measured. A) Values were normalized to the untreated group (no insulin, no IL-1 $\beta$ ). B) Values were normalized to the respective group not treated with insulin. Values show the mean $+/$ - SEM of three independent experiments performed in duplicate. 


\subsubsection{BrCAMP}

Transfected InR1G9 cells were treated with the membrane-permeable cAMP analog 8BrcAMP. Treatment with $1 \mathrm{mM}$ 8BrcAMP for $24 \mathrm{~h}$ increased 1.9-fold basal glucagon gene transcription (Table 1, Figure $14 \mathrm{~A}$ ). In the presence of insulin, the same treatment reversed the insulin-induced inhibition of glucagon gene transcription by $32 \%$ (Table 2 , Figure $14 \mathrm{~B}$ ). When the treatment with $1 \mathrm{mM} 8 \mathrm{BrcAMP}$ was prolonged to $46 \mathrm{~h}$, basal glucagon gene transcription was augmented 2.6-fold (Table 1, Figure $15 \mathrm{~A}$ ). In the presence of insulin, the $46 \mathrm{~h}$ treatment with $1 \mathrm{mM} 8$ BrcAMP reversed the insulin-mediated inhibition of glucagon gene transcription by $18 \%$ (Table 2, Figure $15 \mathrm{~B}$ ).

\subsubsection{Dexamethasone}

InR1G9 cells were treated with $1 \mu \mathrm{M}$ dexamethasone for either 24 or $46 \mathrm{~h}$. Treatment for 24 with dexamethasone inhibited basal glucagon gene transcription by $22 \%$ (Table 1 , Figure $16 \mathrm{~A}$ ). In the presence of insulin, treatment with dexamethasone did not affect the insulin-induced inhibition of glucagon gene transcription (Table 2, Figure 16 B). A longer treatment with dexamethasone, for $46 \mathrm{~h}$, activated 1.1-fold glucagon gene transcription (Table 1, Figure $17 \mathrm{~A}$ ). In the presence of insulin, the $46 \mathrm{~h}$ treatment with dexamethasone increased the insulin inhibitory effect by $12 \%$ (Table 2, Figure $17 \mathrm{~B}$ ).

\subsubsection{Cyclosporin A}

InR1G9 cells were treated for 24 or $46 \mathrm{~h}$ with increasing concentrations of insulin in combination with cyclosporin A. $24 \mathrm{~h}$ exposure to $300 \mathrm{nM}$ cyclosporin A inhibited basal glucagon gene transcription by $20 \%$ (Table 1, Figure $18 \mathrm{~A}$ ). In the presence of insulin, cyclosporin A reversed the insulin-induced inhibition of glucagon gene transcription by 24 $\%$ (Table 2, Figure $18 \mathrm{~B}$ ). Treatment with cyclosporin A for $46 \mathrm{~h}$ did not inhibit basal glucagon gene transcription (Table 1, Figure $19 \mathrm{~A}$ ). In the presence of insulin, a $46 \mathrm{~h}$ treatment with cyclosporin A increased 1.2-fold the insulin effect (Table 2, Figure 19 B). 


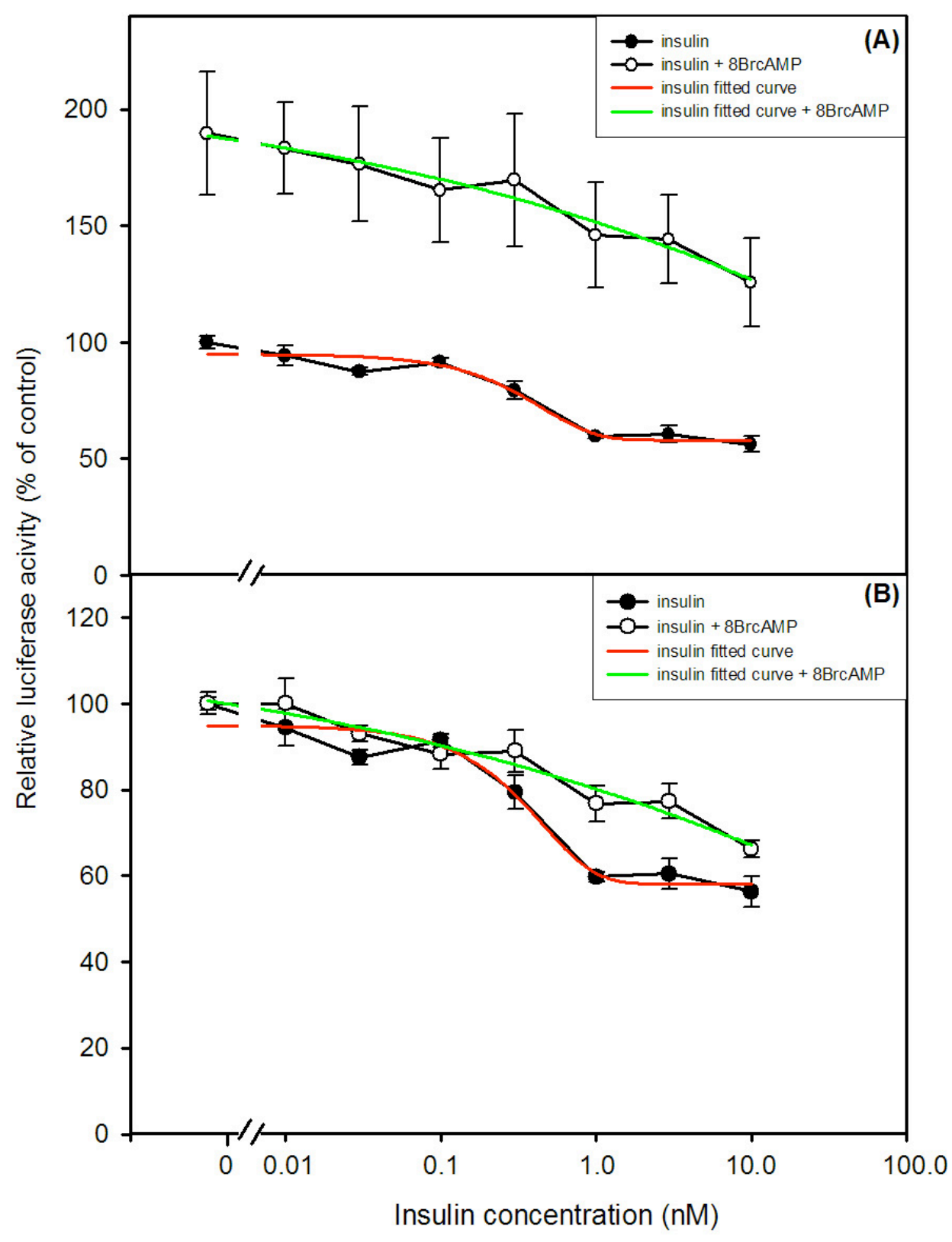

Figure 14. Effect of $24 \mathrm{~h}$ treatment with 8BrcAMP $(1 \mathrm{mM})$ on basal and insulin inducedinhibition of glucagon gene transcription. InR1G9 cells were transfected with $2.0 \mu \mathrm{g} / \mathrm{dish}$ of the -350GluLuc reporter plasmid and $0.5 \mu \mathrm{g} /$ dish of the pGFPtpz-cmv[R] plasmid. $24 \mathrm{~h}$ after transfection, cells were washed with PBS and the medium was replaced with a medium containing $0.5 \%$ BSA. Immediately, $1 \mathrm{mM} 8 \mathrm{BrcAMP}$ was added to the cells. $1 \mathrm{~h}$ later, cells were treated with increasing insulin concentrations. $48 \mathrm{~h}$ after transfection cells were harvested and luciferase and GFP activities were measured. A) Values were normalized to the untreated group (no insulin, no 8BrcAMP). B) Values were normalized to the respective group not treated with insulin. Values show the mean $+/$ - SEM of four independent experiments performed in duplicate. 


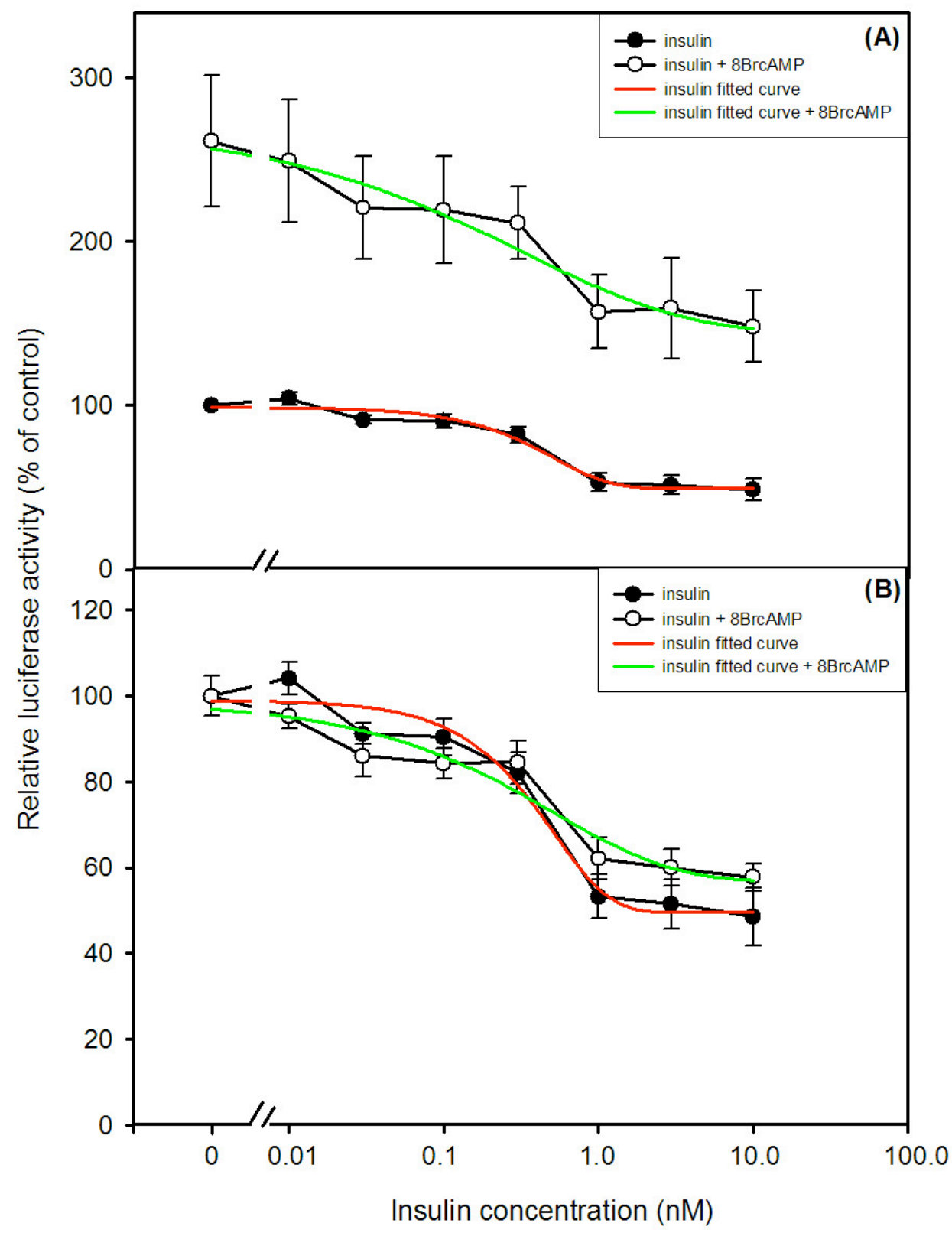

Figure 15. Effect of $46 \mathrm{~h}$ treatment with 8BrcAMP $(1 \mathrm{mM})$ on basal and insulin inducedinhibition of glucagon gene transcription. InR1G9 cells were transfected with $2.0 \mu \mathrm{g} / \mathrm{dish}$ of the -350GluLuc reporter plasmid and $0.5 \mu \mathrm{g} /$ dish of the pGFPtpz-cmv[R] plasmid. $2 \mathrm{~h}$ after transfection, cells were treated with $1 \mathrm{mM}$ 8BrcAMP. $20 \mathrm{~h}$ later, cells were washed with PBS and the medium was replaced with a medium containing $0.5 \%$ BSA. Immediately, $1 \mathrm{mM} 8 \mathrm{BrcAMP}$ was added to the cells. $1 \mathrm{~h}$ later, cells were treated with increasing insulin concentrations. $48 \mathrm{~h}$ after transfection cells were harvested and luciferase and GFP activities were measured. A) Values were normalized to the untreated group (no insulin, no 8BrcAMP). B) Values were normalized to the respective group not treated with insulin. Values show the mean + / SEM of three independent experiments performed in duplicate. 


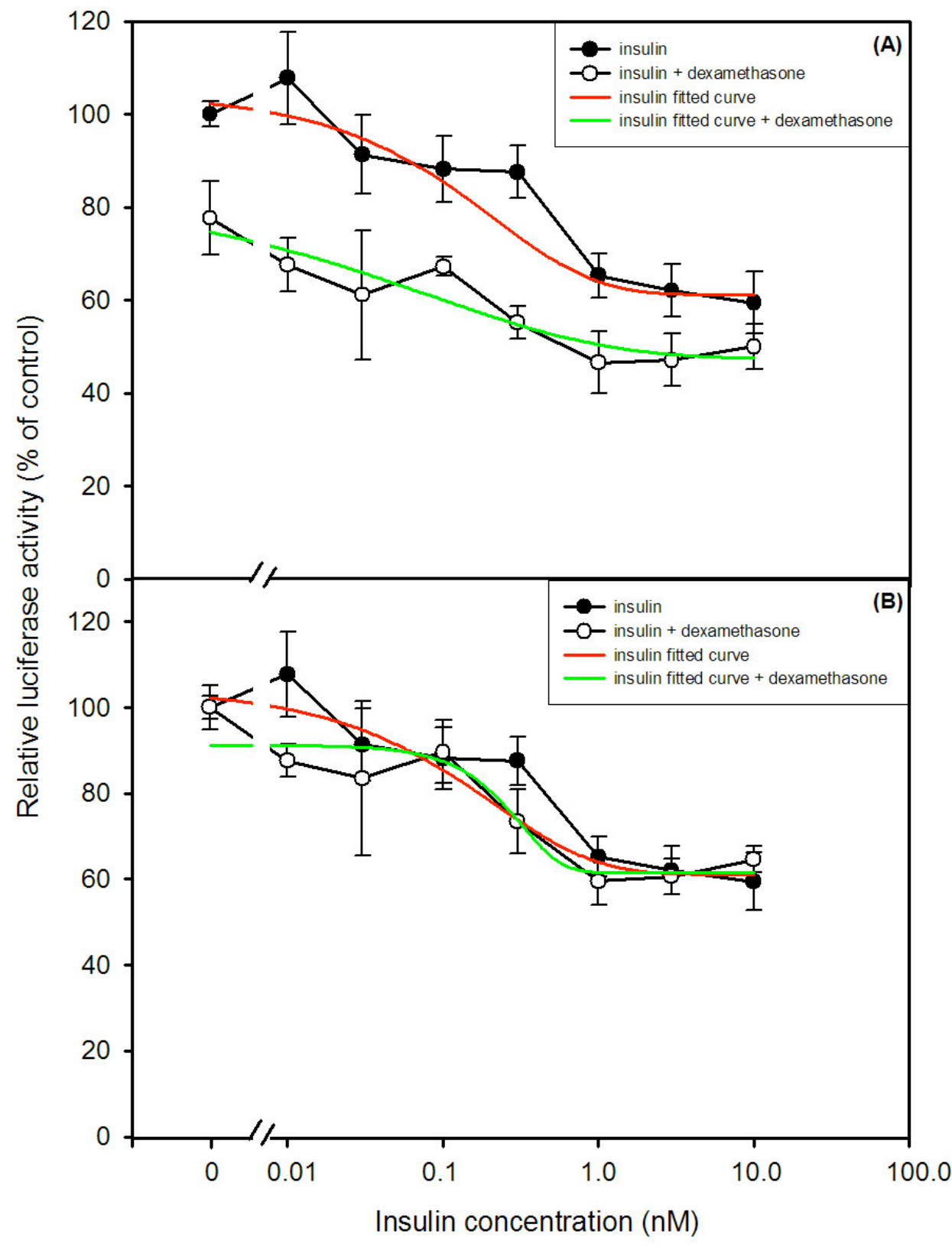

Figure 16. Effect of $24 \mathrm{~h}$ treatment with dexamethasone $(1 \mu \mathrm{M})$ on basal and insulin inducedinhibition of glucagon gene transcription. InR1G9 cells were transfected with $2.0 \mu \mathrm{g} / \mathrm{dish}$ of the -350GluLuc reporter plasmid and $0.5 \mu \mathrm{g} /$ dish of the pGFPtpz-cmv[R] plasmid. $24 \mathrm{~h}$ after transfection, cells were washed with PBS and the medium was replaced with a medium containing $0.5 \%$ BSA. Immediately, $1 \mu \mathrm{M}$ dexamethasone was added to the cells. $1 \mathrm{~h}$ later, cells were treated with increasing insulin concentrations. $48 \mathrm{~h}$ after transfection cells were harvested and luciferase and GFP activities were measured. A) Values were normalized to the untreated group (no insulin, no dexamethasone). B) Values were normalized to the respective group not treated with insulin. Values show the mean + / - SEM of three independent experiments performed in duplicate. 


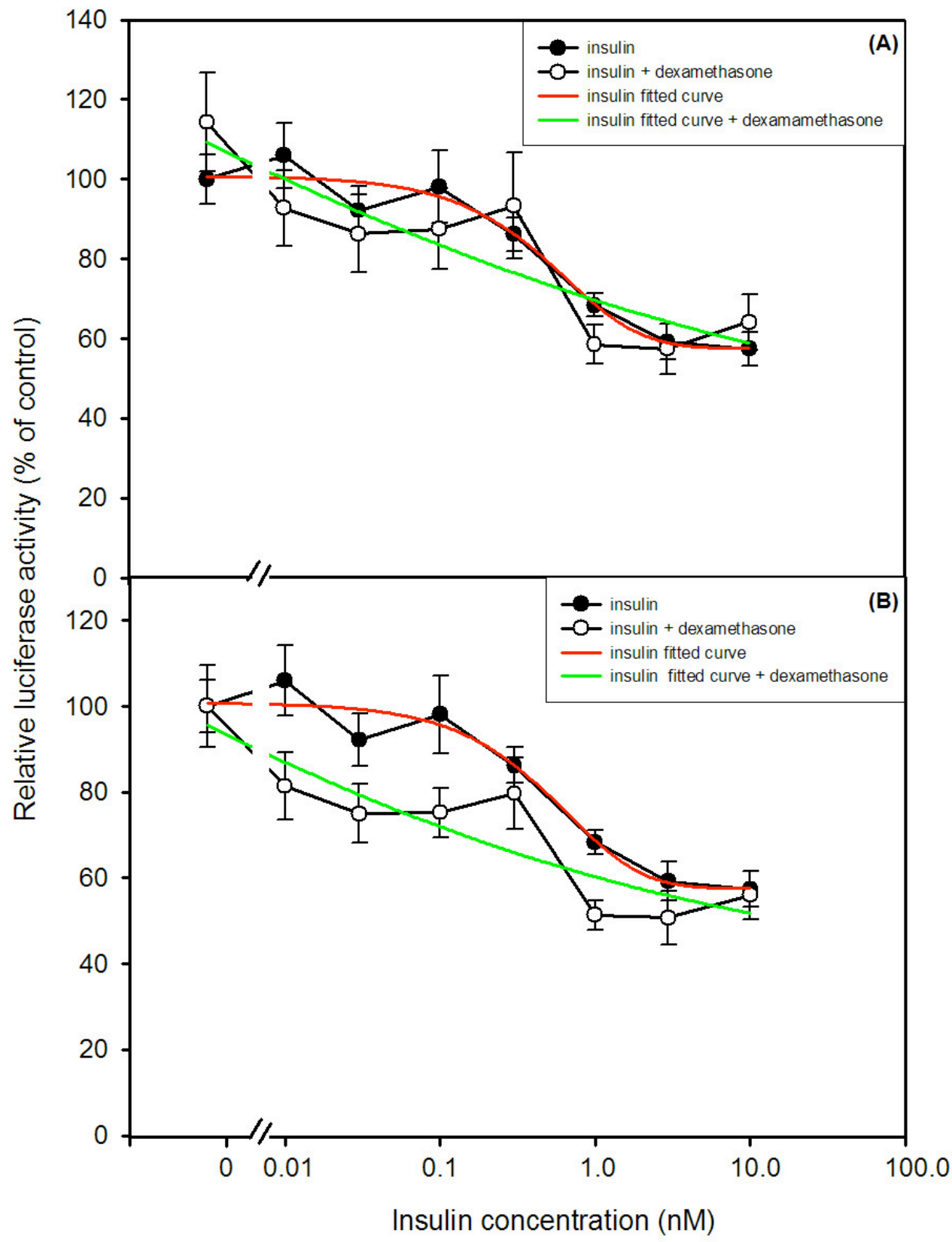

Figure 17. Effect of $46 \mathrm{~h}$ treatment with dexamethasone $(1 \mu \mathrm{M})$ on basal and insulin inducedinhibition of glucagon gene transcription. InR1G9 cells were transfected with $2.0 \mu \mathrm{g} /$ dish of the -350GluLuc reporter plasmid and $0.5 \mu \mathrm{g} /$ dish of the pGFPtpz-cmv[R] plasmid. $2 \mathrm{~h}$ after transfection, cells were treated with $1 \mu \mathrm{M}$ dexamethasone. $20 \mathrm{~h}$ later, cells were washed with PBS and the medium was replaced with a medium containing $0.5 \%$ BSA. Immediately, $1 \mu \mathrm{M}$ dexamethasone was added to the cells. $1 \mathrm{~h}$ later, cells were treated with increasing insulin concentrations. $48 \mathrm{~h}$ after transfection cells were harvested and luciferase and GFP activities were measured. A) Values were normalized to the untreated group (no insulin, no dexamethasone). B) Values were normalized to the respective group not treated with insulin. Values show the mean $+/$ SEM of four independent experiments performed in duplicate. 


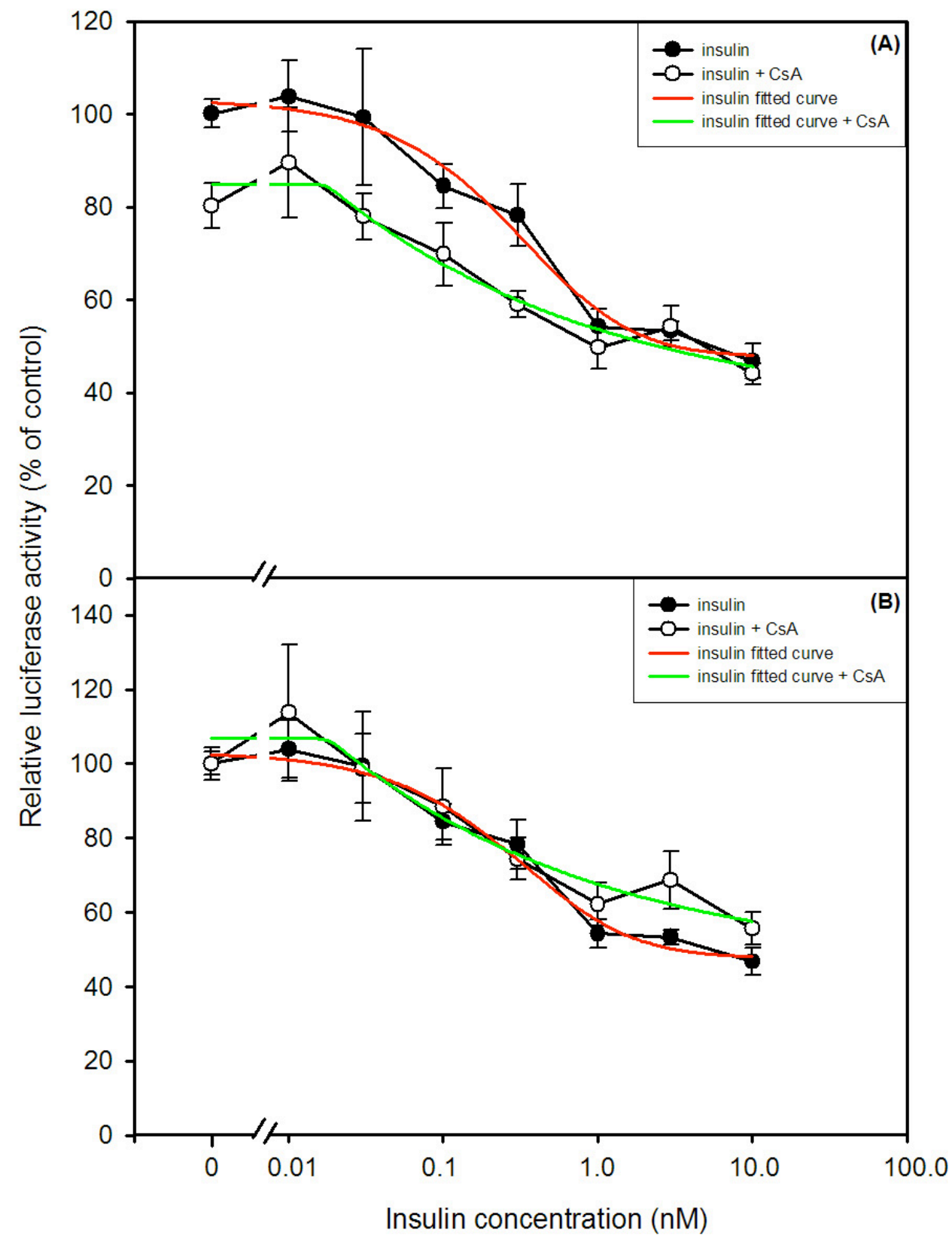

Figure 18. Effect of $24 \mathrm{~h}$ treatment with cyclosporin A (300 nM) on basal and insulin inducedinhibition of glucagon gene transcription. InR1G9 cells were transfected with $2.0 \mu \mathrm{g} /$ dish of the -350GluLuc reporter plasmid and $0.5 \mu \mathrm{g} /$ dish of the pGFPtpz-cmv[R] plasmid. $24 \mathrm{~h}$ after transfection, cells were washed with PBS and the medium was replaced with a medium containing $0.5 \%$ BSA. Immediately, $300 \mathrm{nM}$ cyclosporin A (CsA) was added to the cells. $1 \mathrm{~h}$ later, cells were treated with increasing insulin concentrations. $48 \mathrm{~h}$ after transfection cells were harvested and luciferase and GFP activities were measured. A) Values were normalized to the untreated group (no insulin, no cyclosporin A). B) Values were normalized to the respective group not treated with insulin. Values show the mean $+/$ - SEM of three independent experiments performed in duplicate. 


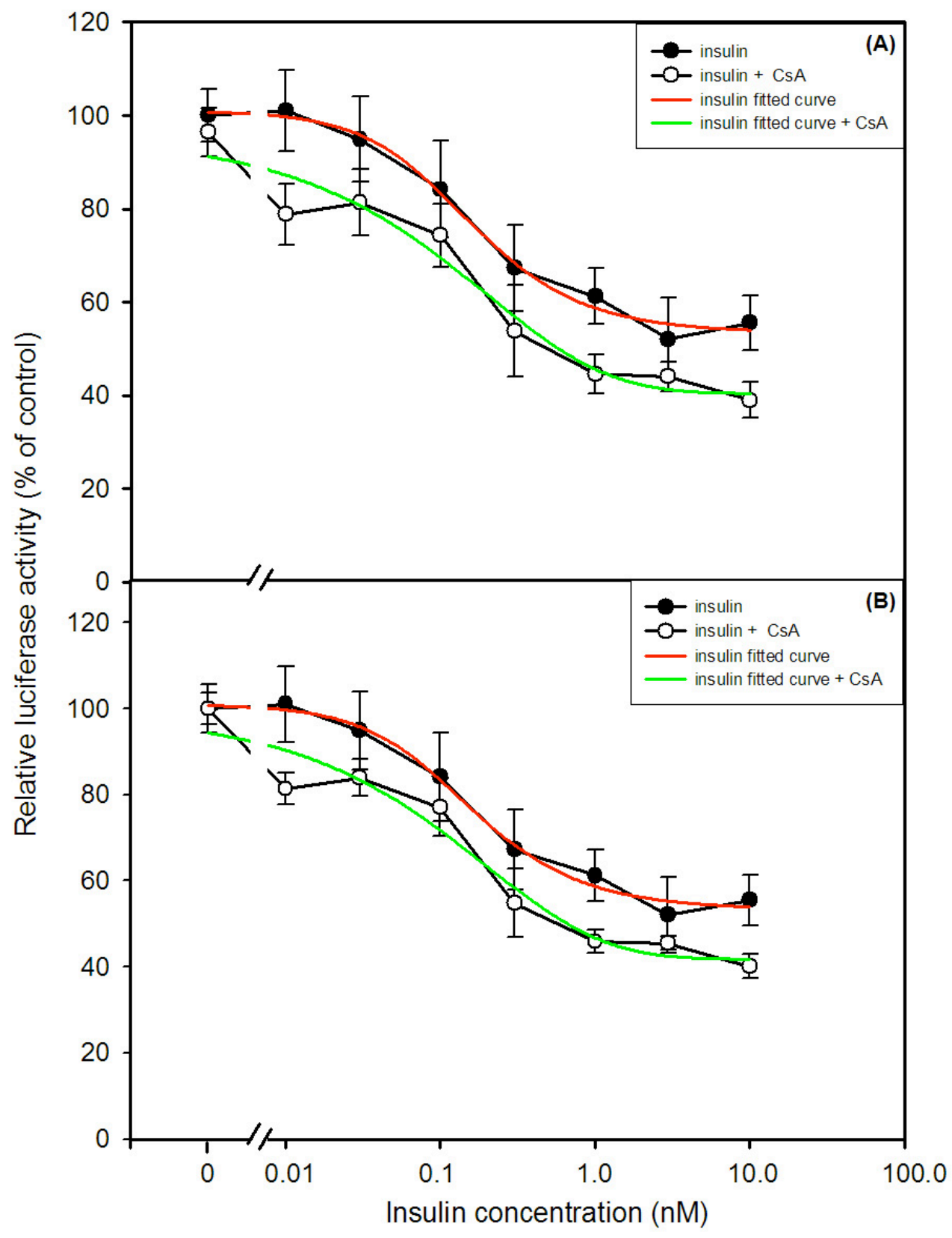

Figure 19. Effect of $46 \mathrm{~h}$ treatment with cyclosporin $\mathrm{A}(300 \mathrm{nM})$ on basal and insulin inducedinhibition of glucagon gene transcription. InR1G9 cells were transfected with $2.0 \mu \mathrm{g} / \mathrm{dish}$ of the -350GluLuc reporter plasmid and $0.5 \mu \mathrm{g} /$ dish of the pGFPtpz-cmv[R] plasmid. $2 \mathrm{~h}$ after transfection, cells were treated with $300 \mathrm{nM}$ cyclosporin A. $20 \mathrm{~h}$ later, cells were washed with PBS and the medium was replaced with a medium containing $0.5 \%$ BSA. Immediately, $300 \mathrm{nM}$ cyclosporin $\mathrm{A}$ was added to the cells. $1 \mathrm{~h}$ later, cells were treated with increasing insulin concentrations. $48 \mathrm{~h}$ after transfection cells were harvested and luciferase and GFP activities were measured. A) Values were normalized to the untreated group (no insulin, no cyclosporin A). B) Values were normalized to the respective group not treated with insulin. Values show the mean $+/$ SEM of two independent experiments performed in duplicate. 


\subsubsection{Tacrolimus}

The effect of a second immunosuppressant, tacrolimus (FK506), on the insulin-induced inhibition of glucagon gene transcription was studied. In the presence of $10 \mathrm{nM}$ tacrolimus, basal glucagon gene transcription was decreased by $15 \%$ (not significant) (Table 1, Figure 20 A). FK506 in combination with insulin reversed the insulin effect by $13 \%$. The $\mathrm{IC}_{50}$ value for the tacrolimus treated group was decreased by $0.3 \mathrm{nM}$ with respect to the control group (Table 2, Figure $20 \mathrm{~B}$ ). Increasing the time of treatment with tacrolimus to 46 $\mathrm{h}$ inhibited basal glucagon gene transcription by $18 \%$ (Table 1, Figure $21 \mathrm{~A}$ ). Combination of the immunosuppressant with insulin did not modify the insulin-induced inhibition of glucagon gene transcription (Table 2, Figure $21 \mathrm{~B}$ ).

\subsubsection{Free fatty acids}

Elevated levels of free fatty acids characterize insulin resistant states. The effect of palmitic, stearic, oleic, linoleic and linolenic acids on basal glucagon gene transcription and on the insulin-mediated inhibition of glucagon gene transcription was studied. The different free fatty acids exerted diverse responses in this tumor cell line. FFA have been considered ligands for nuclear receptors of the family of the peroxisome proliferatoractivated receptor gamma (PPAR $\gamma$ ). The study of the effect of different FFA on glucagon gene transcription was also performed in combination with co-transfection experiments with an expression vector for human PPAR $\gamma$.

\subsubsection{PPARy}

Co-transfection of an expression vector for the human peroxisome proliferator-activated receptor gamma (PPAR $\gamma$ ), in the absence of a ligand, influenced basal glucagon gene transcription. Average of all PPAR $\gamma$ co-transfections performed during the FFA experiments ( $n=34$, see below), showed that PPAR $\gamma$ inhibited basal glucagon gene transcription by $31 \%$ (Table 1, Figure $22 \mathrm{~A}$ ), while in combination with insulin PPAR $\gamma$ reversed the insulin-induced inhibition of glucagon gene transcription by $18 \%$ (Table 2 , Figure $22 \mathrm{~B})$. 


\subsubsection{Palmitic acid [16:0]}

The effect of treatment with palmitic acid, a saturated FFA, on glucagon gene transcription was addressed. In the absence of insulin, treatment for $24 \mathrm{~h}$ with $0.2 \mathrm{mM}$ palmitic acid did not change basal glucagon gene transcription (Table 1, Figure $23 \mathrm{~A}$ ). In the presence of insulin, this FFA did not modify the insulin-induced inhibition of glucagon gene transcription (Table 2, Figure $23 \mathrm{~B}$ ).

\subsubsection{Stearic acid [18:0]}

Treatment of the cells with a longer saturated FFA was also performed. In the absence of insulin, treatment of cells with $0.2 \mathrm{mM}$ stearic acid for $24 \mathrm{~h}$ activated 1.3-fold glucagon gene transcription (Table 1). Combination of stearic acid with insulin did not show any effect on the insulin-induced inhibition of glucagon gene transcription (Table 2, Figure 24 $B)$. 


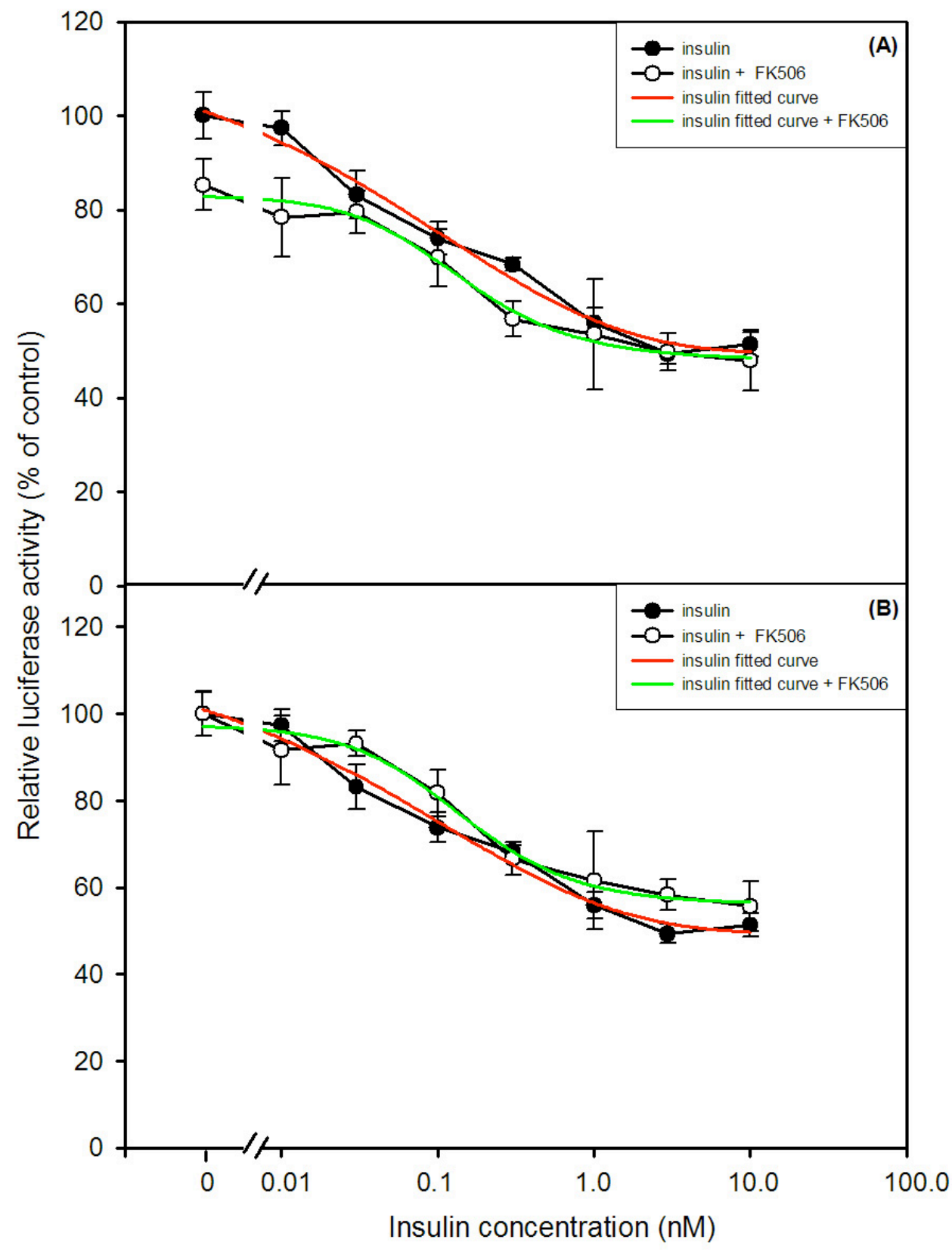

Figure 20. Effect of $24 \mathrm{~h}$ treatment with tacrolimus (10 $\mathrm{nM}$ ) on basal and insulin inducedinhibition of glucagon gene transcription. InR1G9 cells were transfected with $2.0 \mu \mathrm{g} / \mathrm{dish}$ of the -350GluLuc reporter plasmid and $0.5 \mu \mathrm{g} /$ dish of the pGFPtpz-cmv[R] plasmid. $24 \mathrm{~h}$ after transfection, cells were washed with PBS and the medium was replaced with a medium containing $0.5 \%$ BSA. Immediately $10 \mathrm{nM}$ tacrolimus (FK506) was added to the cells. $1 \mathrm{~h}$ later, cells were treated with increasing insulin concentrations. $48 \mathrm{~h}$ after transfection cells were harvested and luciferase and GFP activities were measured. A) Values were normalized to the untreated group (no insulin, no tacrolimus). B) Values were normalized to the respective group not treated with insulin. Values show the mean $+/$ - SEM of two independent experiments performed in duplicate. 


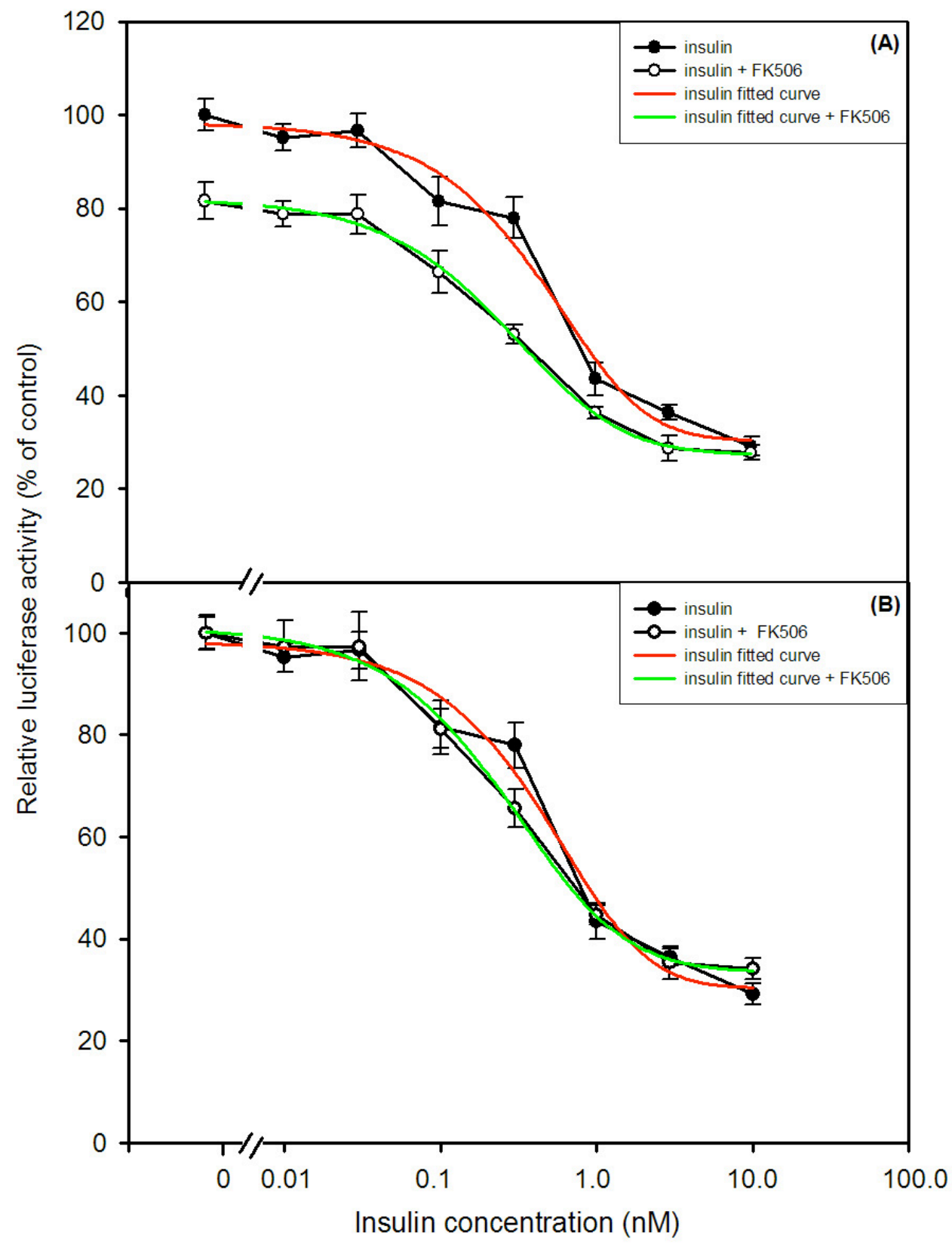

Figure 21. Effect of $46 \mathrm{~h}$ treatment with tacrolimus (10 $\mathrm{nM}$ ) on basal and insulin inducedinhibition of glucagon gene transcription. InR1G9 cells were transfected with $2.0 \mu \mathrm{g} /$ dish of the -350GluLuc reporter plasmid and $0.5 \mu \mathrm{g} /$ dish of the pGFPtpz-cmv[R] plasmid. $2 \mathrm{~h}$ after transfection, cells were treated with $10 \mathrm{nM}$ tacrolimus (FK506). $20 \mathrm{~h}$ later, cells were washed with PBS and the medium was replaced with a medium containing $0.5 \%$ BSA. Immediately, $10 \mathrm{nM}$ FK506 was added to the cells. $1 \mathrm{~h}$ later, cells were treated with increasing insulin concentrations. 48 $\mathrm{h}$ after transfection cells were harvested and luciferase and GFP activities were measured. A) Values were normalized to the untreated group (no insulin, no tacrolimus). B) Values were normalized to the respective group not treated with insulin. Values show the mean $+/$ - SEM of three experiments performed in duplicate. 


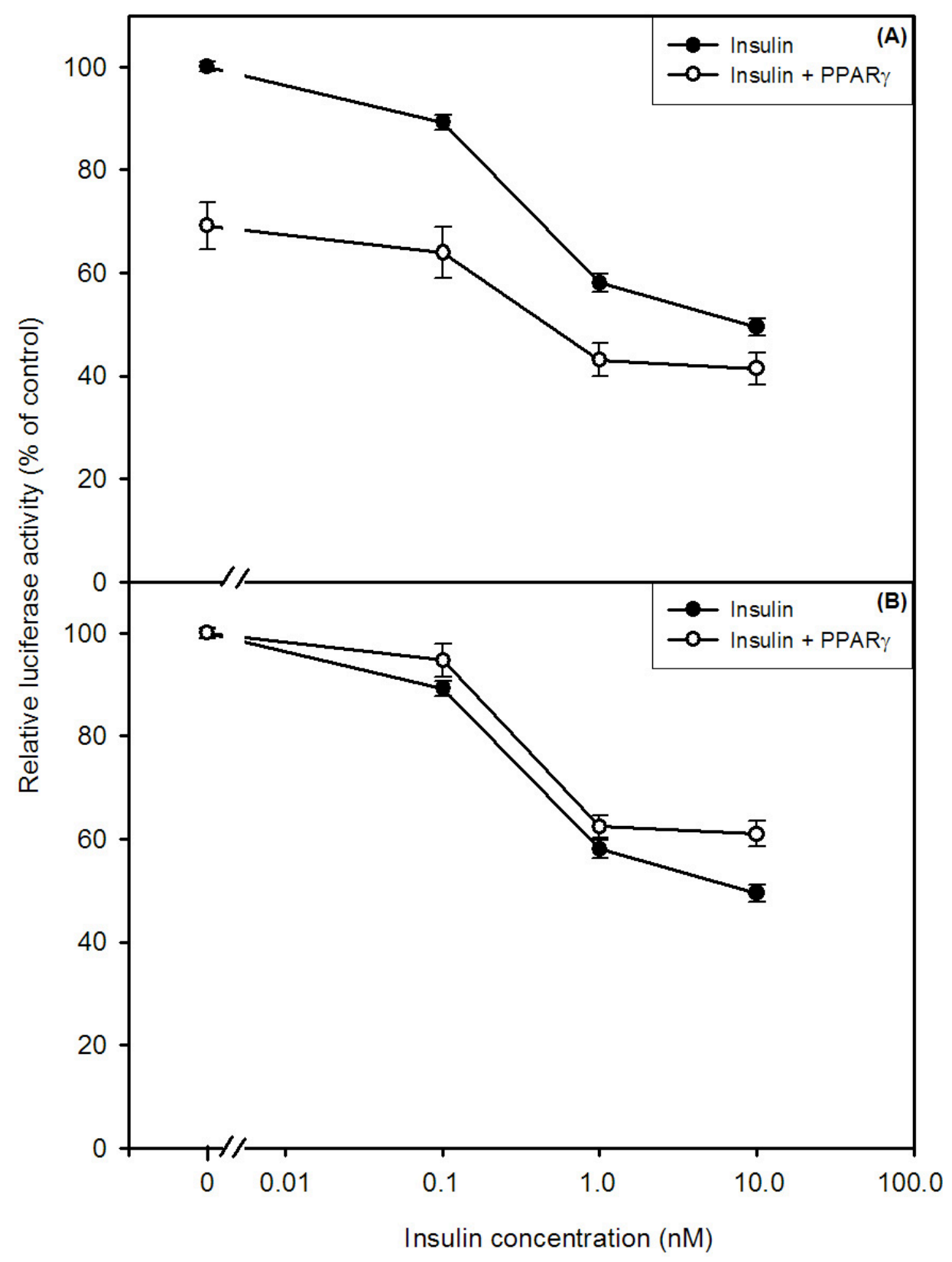

Figure 22. Effect of PPARy co-transfection on basal and insulin induced-inhibition of glucagon gene transcription. InR1G9 cells were transfected with $2.0 \mu \mathrm{g} /$ dish of the -350GluLuc, $0.5 \mu \mathrm{g} /$ dish of the pGFPtpz-cmv[R] plasmid, and $1 \mu \mathrm{g} /$ dish of the hPPAR $\gamma$ plasmid. To maintain a constant amount of DNA pBluescript (Stratagene, La Jolla) was added. $24 \mathrm{~h}$ after transfection, cells were washed with PBS and the medium was replaced with a medium containing $0.5 \%$ BSA. $1 \mathrm{~h}$ later, cells were treated with increasing insulin concentrations. $48 \mathrm{~h}$ after transfection cells were harvested and luciferase and GFP activities were measured. A) Values were normalized to the untreated group (no insulin, no PPAR $\gamma$ ). B) Values were normalized to the respective group not treated with insulin. Values show the mean $+/$ - SEM of seventeen independent experiments performed in duplicate. 


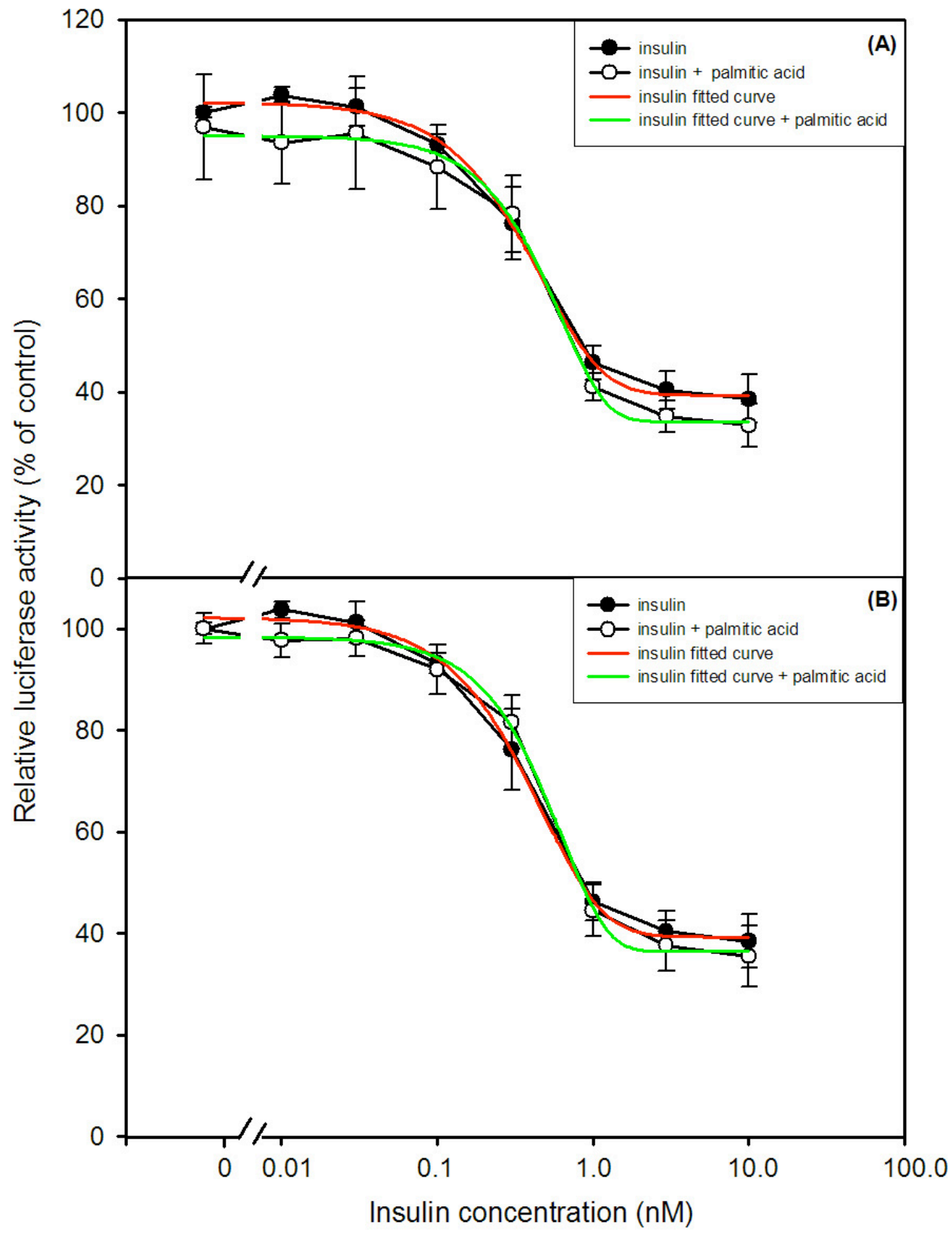

Figure 23. Effect of $24 \mathrm{~h}$ treatment with palmitic acid $(0.2 \mathrm{mM})$ on basal and insulin inducedinhibition of glucagon gene transcription. InR1G9 cells were transfected with $2.0 \mu \mathrm{g} / \mathrm{dish}$ of the -350GluLuc reporter plasmid and $0.5 \mu \mathrm{g} /$ dish of the pGFPtpz-cmv[R] plasmid. $24 \mathrm{~h}$ after transfection, cells were washed with PBS and the medium was replaced with a medium containing $0.2 \mathrm{mM}$ palmitic acid in a solution of $0.5 \%$ fatty acid-free-BSA RPMI medium. $1 \mathrm{~h}$ later, cells were treated with increasing insulin concentrations. $48 \mathrm{~h}$ after transfection cells were harvested and luciferase and GFP activities were measured. A) Values were normalized to the untreated group (no insulin, no palmitic acid). B) Values were normalized to the respective group not treated with insulin. Values show the mean $+/$ - SEM of three independent experiments performed in duplicate. 


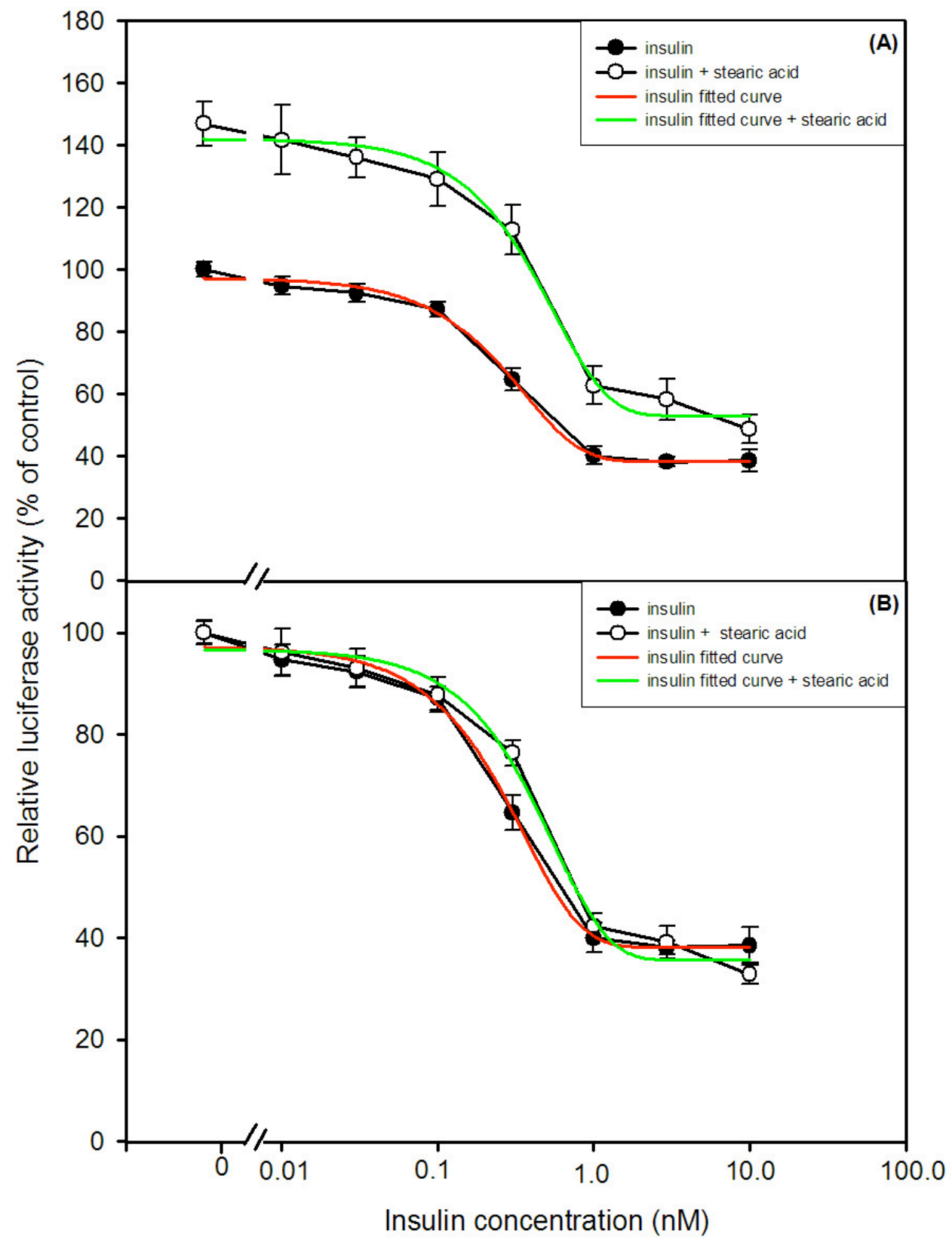

Figure 24. Effect of $24 \mathrm{~h}$ treatment with stearic acid $(0.2 \mathrm{mM})$ on basal and insulin inducedinhibition of glucagon gene transcription. InR1G9 cells were transfected with $2.0 \mu \mathrm{g} / \mathrm{dish}$ of the -350GluLuc reporter plasmid and $0.5 \mu \mathrm{g} /$ dish of the pGFPtpz-cmv[R] plasmid. $24 \mathrm{~h}$ after transfection, cells were washed with PBS and the medium was replaced with a medium containing $0.2 \mathrm{mM}$ stearic acid in a solution of $0.5 \%$ fatty acid-free-BSA RPMI medium. $1 \mathrm{~h}$ later, cells were treated with increasing insulin concentrations. $48 \mathrm{~h}$ after transfection cells were harvested and luciferase and GFP activities were measured. A) Values were normalized to the untreated group (no insulin, no stearic acid). B) Values were normalized to the respective group not treated with insulin. Values show the mean $+/$ - SEM of three independent experiments performed in duplicate. 


\subsubsection{Oleic acid $\left[18: 1 \Delta^{9}\right]$}

Treatment with $0.4 \mathrm{mM}$ oleic acid for $24 \mathrm{~h}$, in the absence of insulin, inhibited basal glucagon gene transcription by $18 \%$ (Table 1 ). Combination of this FFA with insulin increased the insulin-induced inhibition of glucagon gene transcription by $13 \%$ (Table 2 , Figure $25 \mathrm{~B}$ ). When cells were co-transfected with $1 \mu \mathrm{g}$ PPAR $\gamma$, and treated for $24 \mathrm{~h}$ with $0.4 \mathrm{mM}$ oleic acid, basal glucagon gene transcription was reduced by $74 \%$ (Table 1 ).

\subsubsection{Oleic acid [18:1 $\left.\Delta^{9}\right]$ and palmitic acid [16:0]}

The combination of the unsaturated FFA oleic acid and the saturated FFA palmitic acid increased 1.1-fold basal glucagon gene transcription (Table 1). In the presence of insulin, the mixture of these two FFA increased 1.4-fold the insulin-mediated inhibition of glucagon gene transcription (Table 2, Figure $26 \mathrm{~B}$ ). PPAR $\gamma$ in combination with these two FFA inhibited basal glucagon gene transcription by $64 \%$ (Table 1 ).

\subsubsection{Linoleic acid [18:2, $\left.\Delta^{9,12}\right]$}

Treatment with linoleic acid, another unsaturated FFA, inhibited basal glucagon gene transcription by $35 \%$ (Table 1 ). In the presence of insulin, linoleic acid reversed the inhibitory effect of insulin on glucagon gene transcription by $24 \%$. The $\mathrm{IC}_{50}$ value for the linoleic acid treated group was decreased by $0.3 \mathrm{nM}$ in comparison to the control group (Table 2, Figure 27 B). Treatment with linoleic acid of cells co-transfected with PPAR $\gamma$ inhibited basal glucagon gene transcription by $76 \%$ (Table 1 ). 


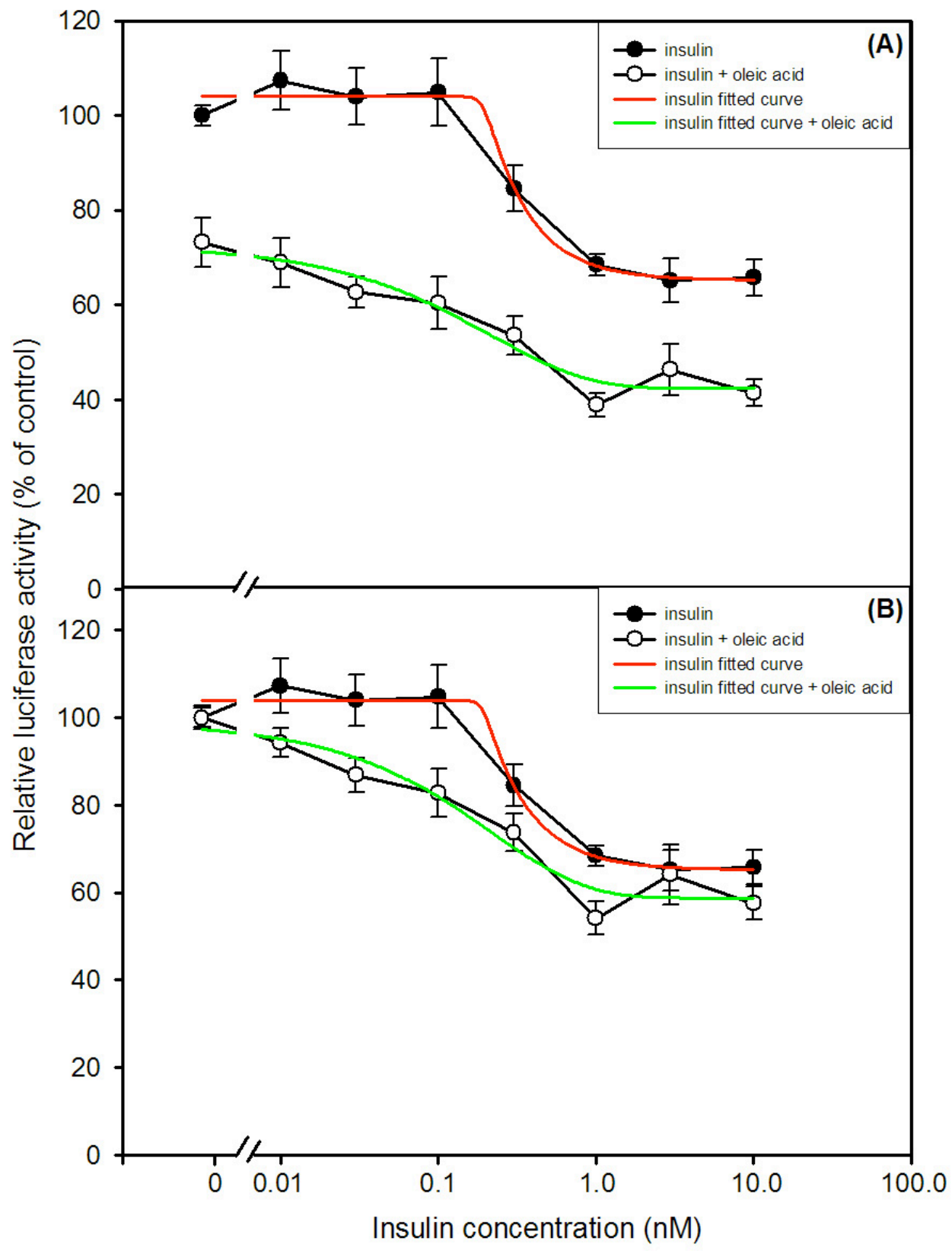

Figure 25. Effect of $24 \mathrm{~h}$ treatment with oleic acid $(0.4 \mathrm{mM})$ on basal and insulin inducedinhibition of glucagon gene transcription. InR1G9 cells were transfected with $2.0 \mu \mathrm{g} / \mathrm{dish}$ of the -350GluLuc reporter plasmid and $0.5 \mu \mathrm{g} /$ dish of the pGFPtpz-cmv[R] plasmid. $24 \mathrm{~h}$ after transfection, cells were washed with PBS and the medium was replaced with a medium containing $0.4 \mathrm{mM}$ oleic acid in a solution of $0.5 \%$ fatty acid-free-BSA RPMI medium. $1 \mathrm{~h}$ later, cells were treated with increasing insulin concentrations. $48 \mathrm{~h}$ after transfection cells were harvested and luciferase and GFP activities were measured. A) Values were normalized to the untreated group (no insulin, no oleic acid). B) Values were normalized to the respective group not treated with insulin. Values show the mean $+/$ - SEM of four independent experiments performed in duplicate. 


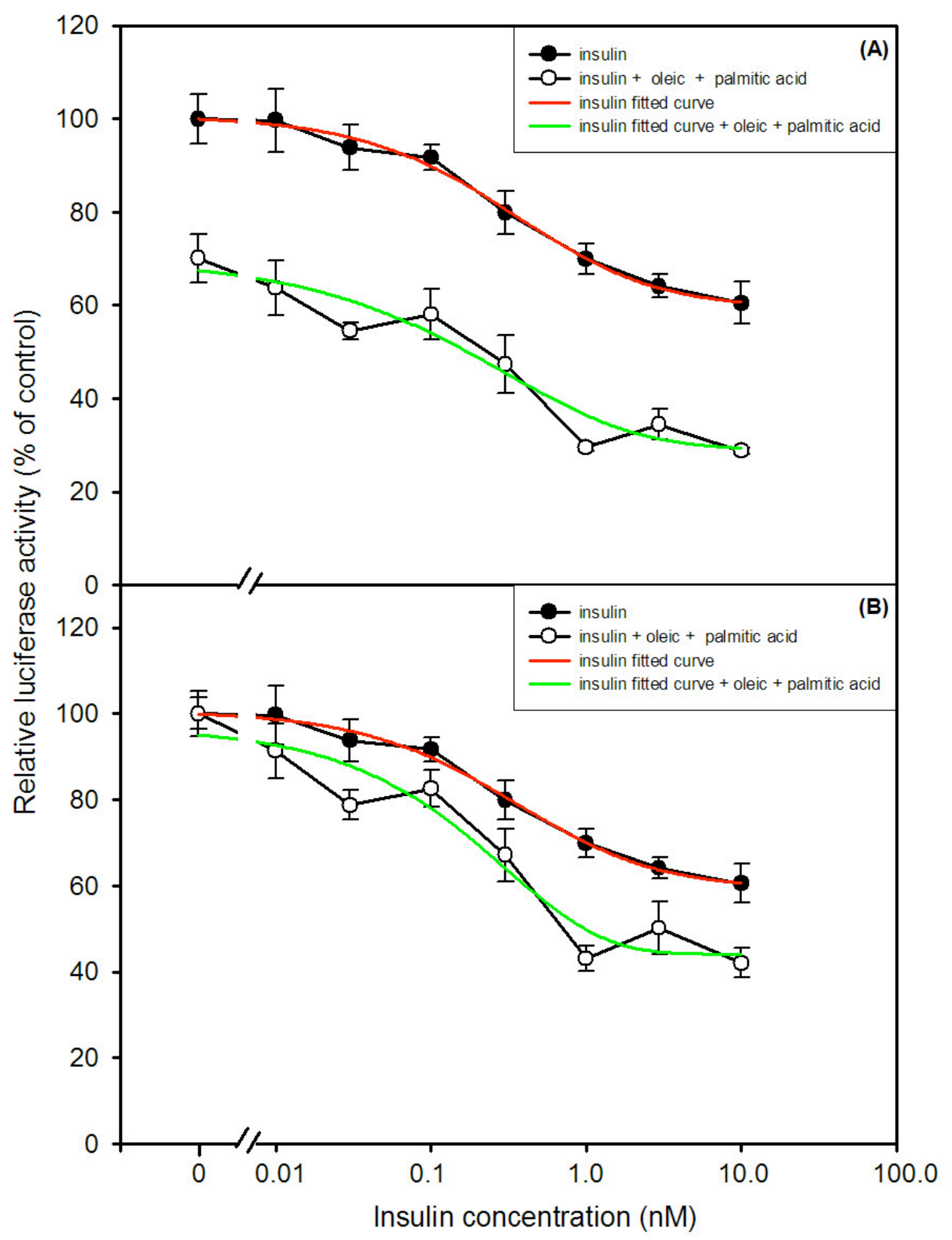

Figure 26. Effect of $24 \mathrm{~h}$ treatment with oleic acid $(0.2 \mathrm{mM})$ and palmitic acid $(0.2 \mathrm{mM})$ on basal and insulin induced-inhibition of glucagon gene transcription. InR1G9 cells were transfected with $2.0 \mu \mathrm{g} /$ dish of the $-350 \mathrm{GluLuc}$ reporter plasmid and $0.5 \mu \mathrm{g} /$ dish of the pGFPtpz$\mathrm{cmv}[\mathrm{R}]$ plasmid. $24 \mathrm{~h}$ after transfection, cells were washed with PBS and the medium was replaced with a medium containing $0.2 \mathrm{mM}$ oleic acid and $0.2 \mathrm{mM}$ palmitic acid in a solution of $0.5 \%$ fatty acid-free-BSA RPMI medium. $1 \mathrm{~h}$ later, cells were treated with increasing insulin concentrations. 48 $\mathrm{h}$ after transfection cells were harvested and luciferase and GFP activities were measured. A) Values were normalized to the untreated group (no insulin, no oleic acid and no palmitic acid). B) Values were normalized to the respective group not treated with insulin. Values show the mean $+/$ SEM of three independent experiments performed in duplicate. 


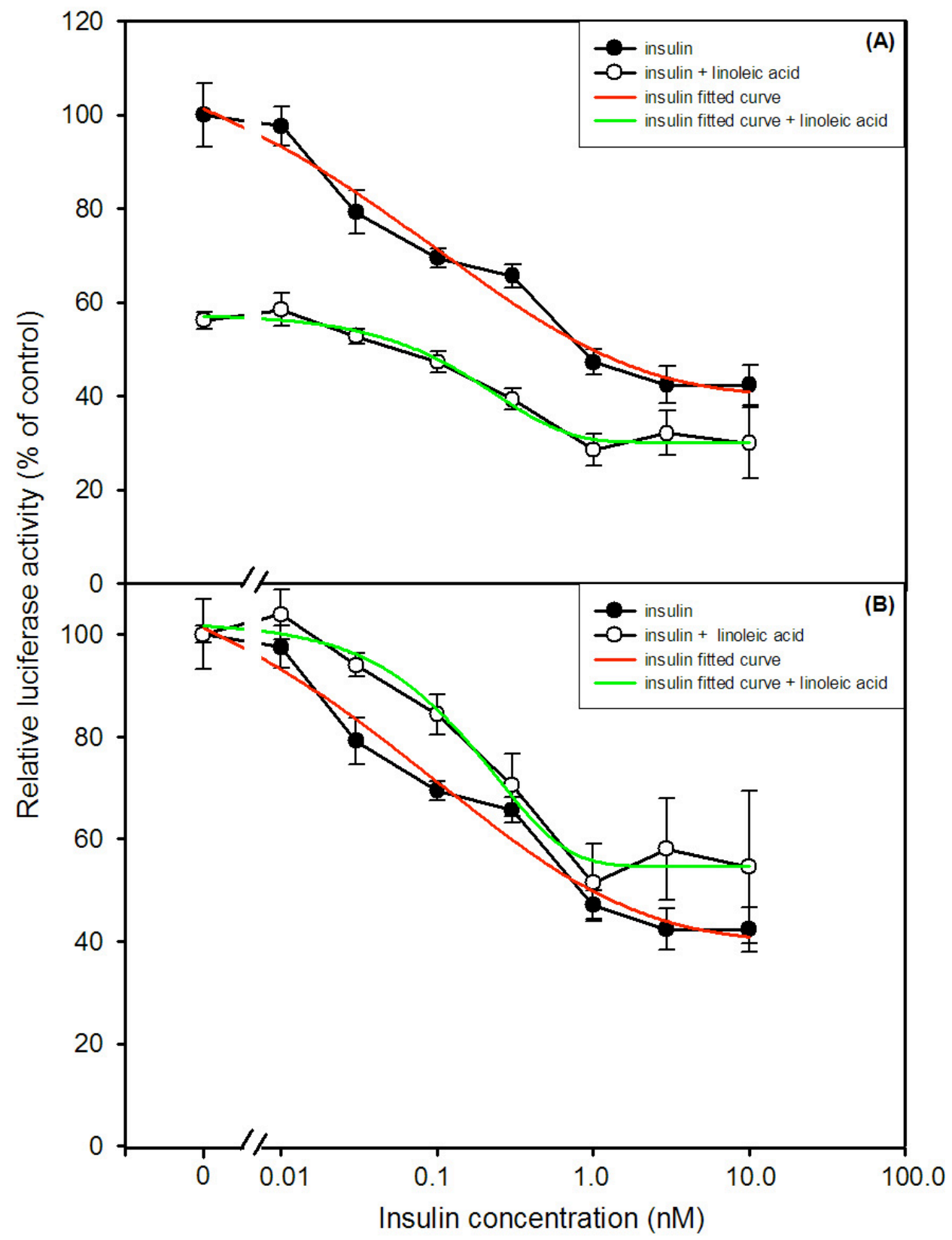

Figure 27. Effect of $24 \mathrm{~h}$ treatment with linoleic acid $(0.4 \mathrm{mM})$ on basal and insulin inducedinhibition of glucagon gene transcription. InR1G9 cells were transfected with $2.0 \mu \mathrm{g} / \mathrm{dish}$ of the -350GluLuc reporter plasmid and $0.5 \mu \mathrm{g} /$ dish of the pGFPtpz-cmv[R] plasmid. $24 \mathrm{~h}$ after transfection, cells were washed with PBS and the medium was replaced with a medium containing $0.4 \mathrm{mM}$ linoleic acid in a solution of $0.5 \%$ fatty acid-free-BSA RPMI medium. $1 \mathrm{~h}$ later, cells were treated with increasing insulin concentrations. $48 \mathrm{~h}$ after transfection cells were harvested and luciferase and GFP activities were measured. A) Values were normalized to the untreated group (no insulin, no linoleic acid). B) Values were normalized to the respective group not treated with insulin. Values show the mean + / SEM of two independent experiments performed in duplicate. 


\subsubsection{Linolenic acid [18:3, $\left.\Delta^{9,12,15}\right]$}

Treatment of cells with the unsaturated FFA linolenic acid inhibited basal glucagon gene transcription by $54 \%$ (Table 1, Figure $28 \mathrm{~A}$ ). In the presence of insulin, treatment with 0.4 $\mathrm{mM}$ linolenic acid for $24 \mathrm{~h}$ increased the insulin-mediated inhibition of glucagon gene transcription by $15 \%$ (Table 2, Figure $28 \mathrm{~B}$ ). Combination of a linolenic acid treatment with co-transfected PPAR $\gamma$ inhibited basal glucagon gene transcription by $58 \%$ (Table 1 ). 


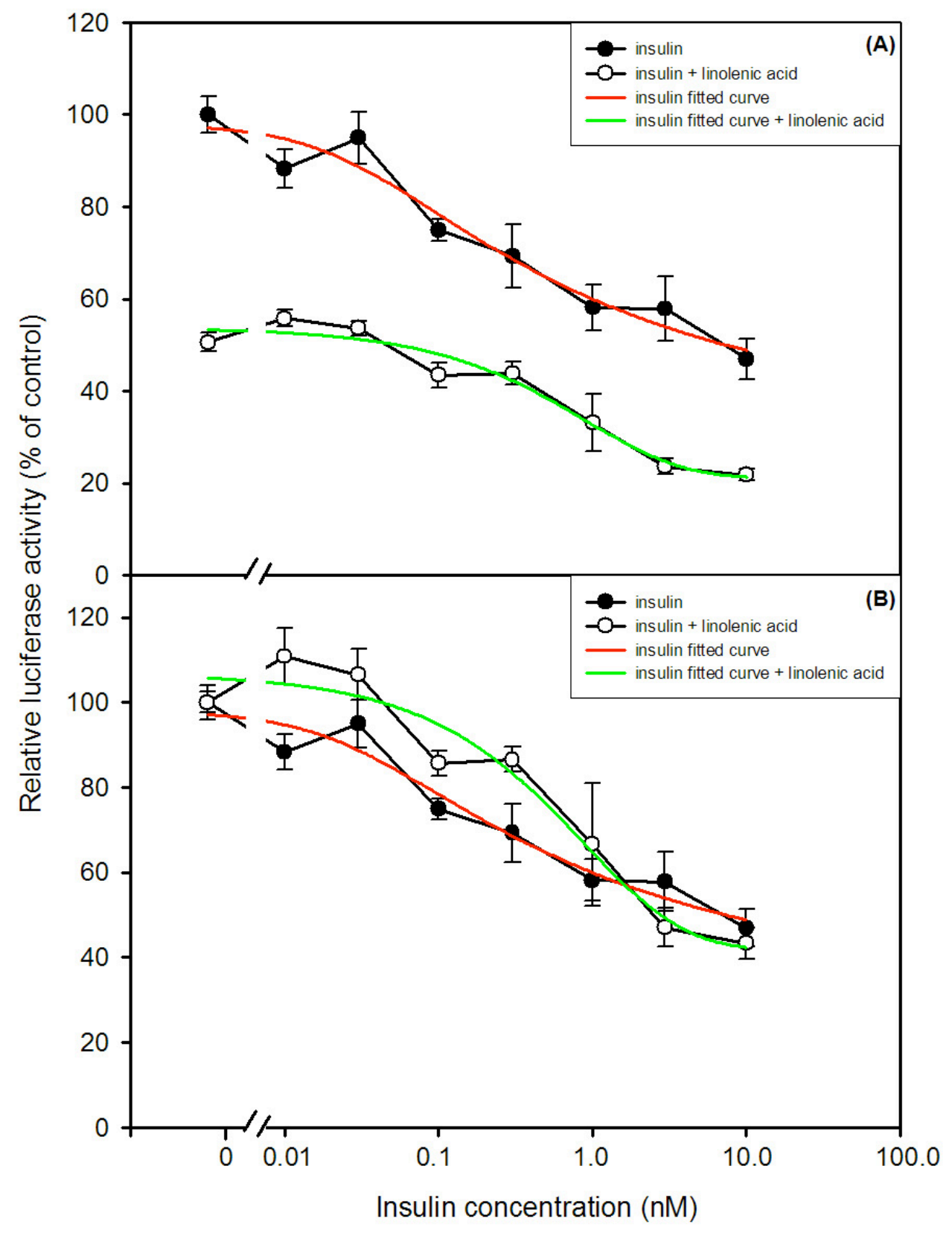

Figure 28. Effect of $24 \mathrm{~h}$ treatment with linolenic acid $(0.4 \mathrm{mM})$ on basal and insulin inducedinhibition of glucagon gene transcription. InR1G9 cells were transfected with $2.0 \mu \mathrm{g} / \mathrm{dish}$ of the -350GluLuc reporter plasmid and $0.5 \mu \mathrm{g} /$ dish of the pGFPtpz-cmv[R] plasmid. $24 \mathrm{~h}$ after transfection, cells were washed with PBS and the medium was replaced with a medium containing $0.4 \mathrm{mM}$ linolenic acid in a solution of $0.5 \%$ fatty acid-free-BSA RPMI medium. $1 \mathrm{~h}$ later, cells were treated with increasing insulin concentrations. $48 \mathrm{~h}$ after transfection cells were harvested and luciferase and GFP activities were measured. A) Values were normalized to the untreated group (no insulin, no linolenic acid). B) Values were normalized to the respective group not treated with insulin. Values show the mean $+/$ - SEM of two independent experiments performed in duplicate. 


\subsubsection{Hydrogen peroxide}

The effect of hydrogen peroxide $\left(\mathrm{H}_{2} \mathrm{O}_{2}\right)$, a reactive oxygen species (ROS), on the insulininduced inhibition of glucagon gene transcription was investigated. Transfected cells were treated with 10,33 or $100 \mu \mathrm{M} \mathrm{H}_{2} \mathrm{O}_{2}$ in combination with 1 or $3 \mathrm{nM}$ insulin. As shown in figure 29, both insulin concentrations showed $50 \%$ inhibition of glucagon gene transcription. Treatment of cells with increasing $\mathrm{H}_{2} \mathrm{O}_{2}$ concentrations for $24 \mathrm{~h}$ showed a dose-dependent inhibition of basal glucagon gene transcription (10 and $33 \mu \mathrm{M} \mathrm{H}_{2} \mathrm{O}_{2}$ inhibited basal transcription by 17 and $29 \%$, respectively (Table 1, Figure 29). $100 \mu \mathrm{M}$ $\mathrm{H}_{2} \mathrm{O}_{2}$ produced a detrimental effect on cell viability (not shown). Combination of $\mathrm{H}_{2} \mathrm{O}_{2}$ with distinct insulin concentrations did not modify the insulin-mediated inhibition of glucagon gene transcription (Table 2, Figure 29).

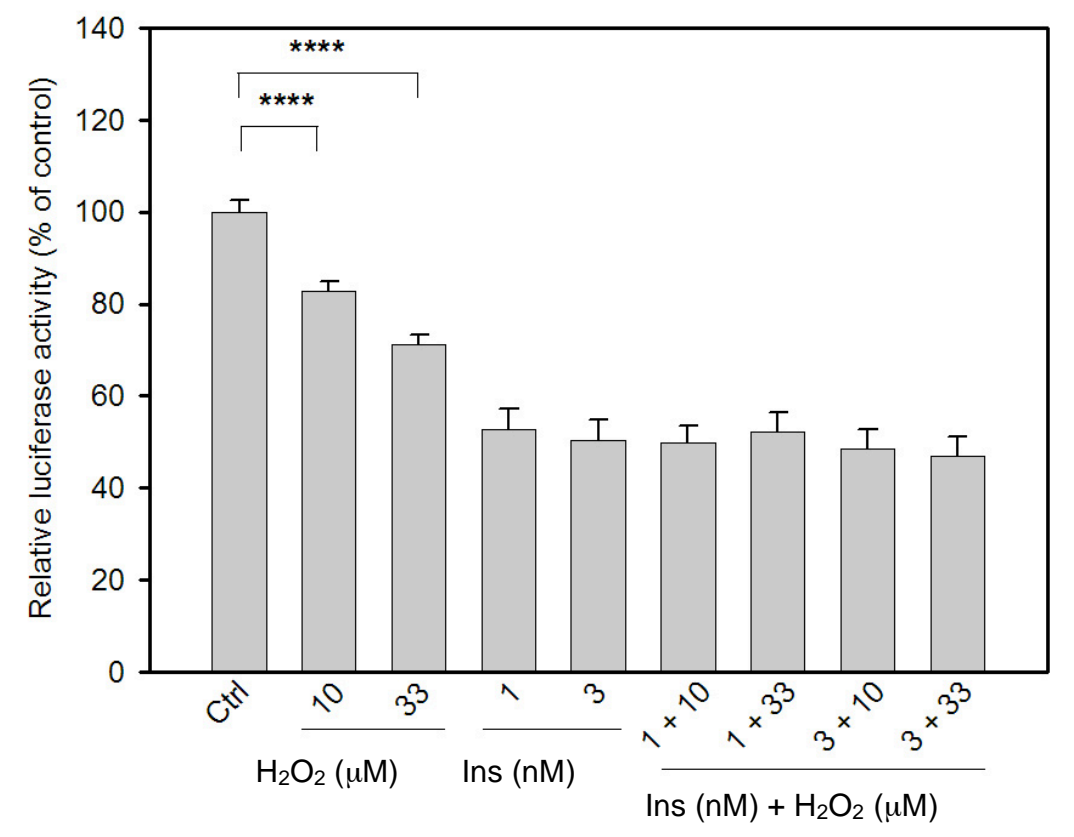

Figure 29. Effect of $\mathbf{2 4} \mathrm{h}$ treatment with hydrogen peroxide on basal and insulin inducedinhibition of glucagon gene transcription. InR1G9 cells were transfected with $2.0 \mu \mathrm{g} / \mathrm{dish}$ of the $-350 \mathrm{GluLuc}$ reporter plasmid and $0.5 \mu \mathrm{g} /$ dish of the pGFPtpz-cmv[R] plasmid. $24 \mathrm{~h}$ after transfection, cells were washed with PBS and the medium was replaced with a medium containing $0.5 \%$ BSA. Immediately, either 10 or $33 \mu \mathrm{M} \mathrm{H}_{2} \mathrm{O}_{2}$ was added to the cells. $1 \mathrm{~h}$ later, cells were treated with either 1 or $3 \mathrm{nM}$ insulin (alone or in combination with $\mathrm{H}_{2} \mathrm{O}_{2}$ ). $48 \mathrm{~h}$ after transfection cells were harvested and luciferase and GFP activities were measured. Values were normalized to the untreated group (no insulin, no $\mathrm{H}_{2} \mathrm{O}_{2}$ ) and show the mean + / - SEM of five independent experiments performed in triplicate. Statistical analysis was performed by paired Student t-test. ${ }^{* * * *} \mathrm{p}<0.00005$. 


\subsubsection{Tribbles 3 (TRB3)}

Protein kinase $\mathrm{B}$, a kinase involved in the regulation of insulin signaling and glucose homeostasis, forms complexes with other proteins that modulate its activity and function. Interaction of PKB with the overexpressed form of the mammalian homolog of the Drosophila tribbles 3 (TRB3) contributes to impaired downstream insulin signaling (Du et al., 2003). Impaired PKB function caused insulin resistance and diabetes mellitus in human and in animal models (Cho et al., 2001; George et al., 2004; Schinner et al., 2005b). Co-transfection experiments with a plasmid for TRB3 and with a plasmid for a constitutively active form of protein kinase $B\left(\mathrm{PKB}_{\text {myr }}\right)$ were performed. $\mathrm{PKB}_{\text {myr }}$ transfection inhibited glucagon gene transcription by $30 \%$. Transfection with TRB3, in the absence of insulin, activated 2.8-fold glucagon gene transcription. This activation was reversed by either co-transfection of TRB3 and $\mathrm{PKB}_{\text {myr }}$ or by transfection of TRB3 followed by insulin treatment (Table 1, Figure 30).

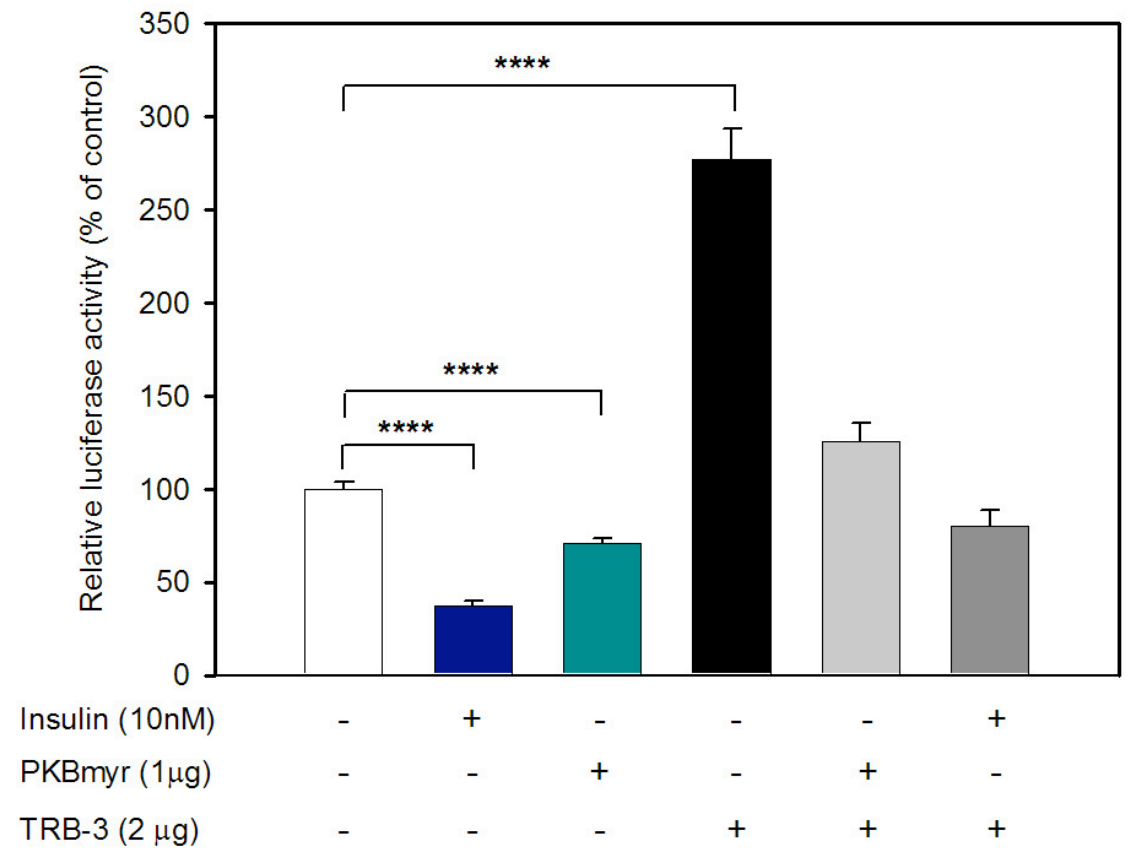

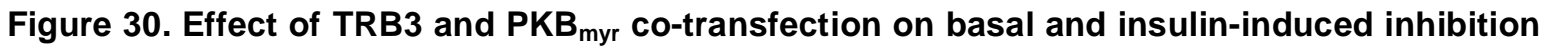
of glucagon gene transcription. InR1G9 cells were co-transfected with $2 \mu \mathrm{g} /$ dish of the 350GluLuc reporter plasmid, $0.5 \mu \mathrm{g} /$ dish pGFPtpz-cmv[R], $2 \mu \mathrm{g} /$ dish TRB3 and $1 \mu \mathrm{g} /$ dish

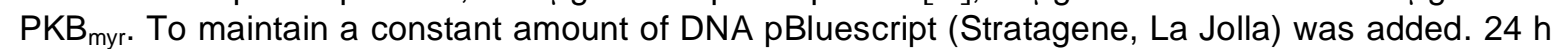
after transfection, cells were washed with PBS and the medium was replaced with a medium containing $0.5 \%$ BSA. $1 \mathrm{~h}$ later, $10 \mathrm{nM}$ insulin was added to the cells. $48 \mathrm{~h}$ after transfection cells were harvested and luciferase and GFP activities were measured. Values were normalized to the untreated group (no insulin) and show the mean + / - SEM of four independent experiments performed in triplicate. Statistical analysis was performed by paired Student t-test. ${ }^{* * \star *} p<0.00005$. 


\subsubsection{Chronic insulin}

The effect of chronic insulin treatment on the insulin-induced inhibition of glucagon gene transcription was investigated. Transfected InR1G9 cells were treated with insulin for $23 \mathrm{~h}$ or for $46 \mathrm{~h}$ (chronic insulin treatment). The $23 \mathrm{~h}$ treatment inhibited glucagon gene transcription (Figure 31) as shown in Figure 6 . The $46 \mathrm{~h}$ chronic insulin treatment did not show an inhibitory effect on glucagon gene transcription (Table 2, Figure 31).

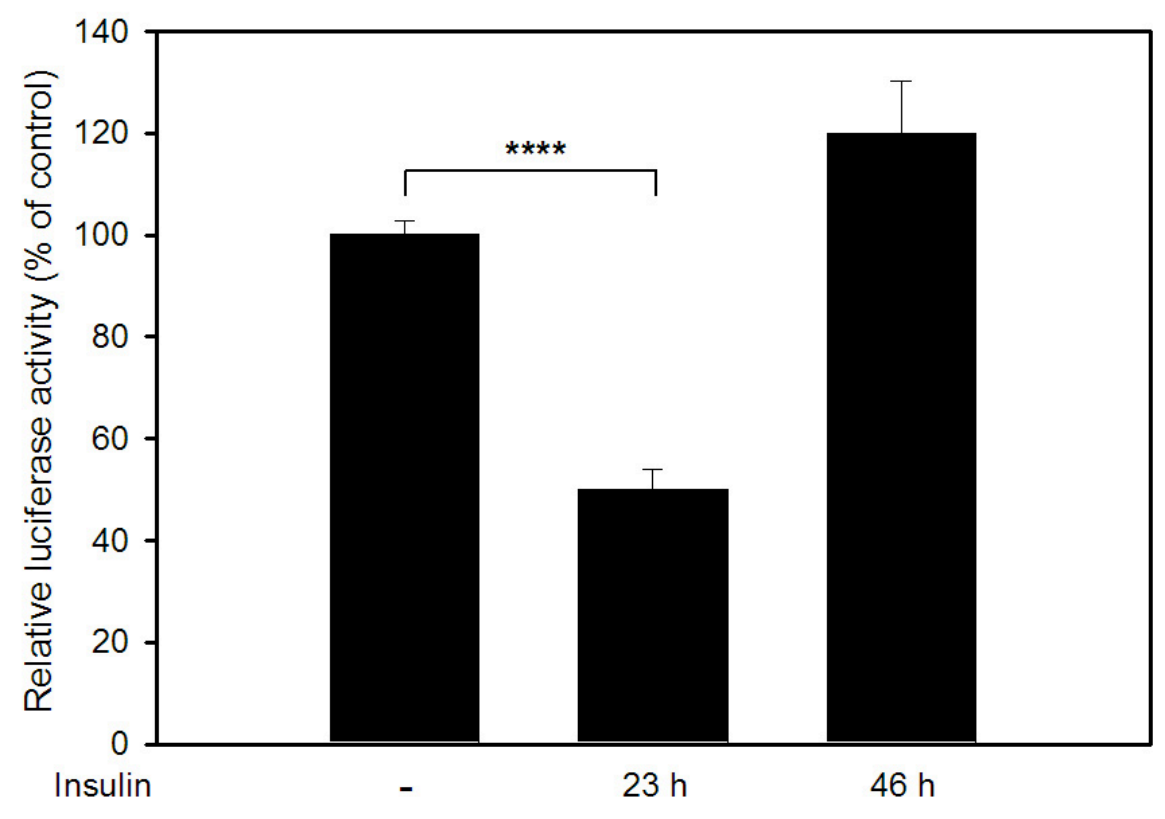

Figure 31. Effect of a chronic insulin treatment on glucagon gene transcription. InR1G9 cells were transfected with $2.0 \mu \mathrm{g} /$ dish of the $-350 \mathrm{GluLuc}$ reporter plasmid and $0.5 \mu \mathrm{g} / \mathrm{dish}$ of the pGFPtpz-cmv[R] plasmid. $2 \mathrm{~h}$ after transfection, cells were treated with $100 \mathrm{mM}$ insulin (medium containing serum). $20 \mathrm{~h}$ later, cells were washed with PBS and the medium was replaced with a medium containing $0.5 \%$ BSA. Immediately, $100 \mathrm{nM}$ insulin was added to the cells $(46 \mathrm{~h}$ treatment). $1 \mathrm{~h}$ later, cells were treated with $10 \mathrm{nM}$ insulin ( $23 \mathrm{~h}$ treatment). $48 \mathrm{~h}$ after transfection cells were harvested and luciferase and GFP activities were measured. Values were normalized to the untreated group (no insulin) and show the mean $+/$ - SEM of four independent experiments performed in triplicate. Statistical analysis was performed by one way-ANOVA followed by Scheffe test. ${ }^{* * \star *} \mathrm{p}<0.00005$. 


\subsubsection{Summary of the effect of substances known to induce insulin resistance in other tissues, on the inhibition of glucagon gene transcription in $\alpha$-cells}

The results obtained are summarized in two different tables. Table 1 shows the effect of the different treatments on basal glucagon gene transcription. This table displays the treatment performed, the duration of the treatment, the number of replicates, the effect as a percentage of the control, the standard error of the mean for the effect and the statistical significance calculated after a Student t-test, as well as the respective P values. Table 2 presents the effect of the different substances on the insulin-mediated inhibition of glucagon gene transcription. This table contains the treatment performed and its duration, the number of replicates, the $\mathrm{IC}_{50}$ concentration as well as the maximal insulin effect (Insulin $E_{\max }$ ). 


\begin{tabular}{|c|c|c|c|c|c|c|c|}
\hline Treatment & $t(h)$ & $n$ & $\begin{array}{c}\text { Effect } \\
\text { ( } \% \\
\text { control) }\end{array}$ & SEM & $T$-test & $P$ & \\
\hline - & - & 10 & 100 & 5 & - & - & \\
\hline $10 \mathrm{nM}$ insulin & 23 & 10 & 52 & 9 & - & & \\
\hline $10 \mathrm{ng} / \mathrm{ml}$ TNF $\alpha$ & 24 & 8 & 93 & 7 & 0.3128 & & \\
\hline $10 \mathrm{ng} / \mathrm{ml}$ TNF $\alpha$ & 46 & 6 & 94 & 6 & 0.4350 & & \\
\hline $100 \mathrm{ng} / \mathrm{ml}$ TNF $\alpha$ & 24 & 4 & 77 & 4 & 0.0009 & $* * *$ & 0 \\
\hline 20 ng / ml Interleukin 6 & 24 & 6 & 121 & 8 & 0.1229 & & \\
\hline $20 \mathrm{ng} / \mathrm{ml}$ Interleukin 6 & 46 & 6 & 105 & 4 & 0.4001 & & \\
\hline $10 \mathrm{ng} / \mathrm{ml}$ IL-1 $\beta$ & 24 & 6 & 25 & 1 & 0.0000 & $* \star *$ & \\
\hline $1 \mathrm{mM}$ 8BrcAMP & 24 & 8 & 190 & 26 & 0.0045 & ** & \\
\hline $1 \mathrm{mM} 8 \mathrm{BrcAMP}$ & 46 & 6 & 261 & 40 & 0.0024 & ** & \\
\hline $1 \mu \mathrm{M}$ Dexamethasone & 24 & 6 & 78 & 8 & 0.0240 & * & \\
\hline $1 \mu \mathrm{M}$ Dexamethasone & 46 & 8 & 114 & 12 & 0.3198 & & \\
\hline 300 nM Cyclosporin A & 24 & 6 & 80 & 5 & 0.0062 & ** & \\
\hline 300 nM Cyclosporin A & 46 & 4 & 96 & 5 & 0.6500 & & \\
\hline 10 nM Tacrolimus & 24 & 4 & 85 & 5 & 0.0925 & & \\
\hline $10 \mathrm{nM}$ Tacrolimus & 46 & 6 & 82 & 4 & 0.0053 & ** & \\
\hline $1 \mu \mathrm{g}$ hPPAR $\gamma$ & 24 & 34 & 69 & 4 & 0.0000 & $* * *$ & 0 \\
\hline $0.2 \mathrm{mM}$ palmitic acid & 24 & 12 & 104 & 6 & 0.5601 & & \\
\hline $1 \mu \mathrm{g} \mathrm{hPPAR} \gamma$ & 24 & 6 & 41 & 5 & 0.0000 & $* \star *$ & \\
\hline $0.2 \mathrm{mM}$ palmitic acid $+1 \mu \mathrm{g}$ hPPAR $\gamma$ & 24 & 6 & 45 & 4 & 0.0000 & $* \star *$ & \\
\hline $0.2 \mathrm{mM}$ stearic acid & 24 & 14 & 132 & 8 & 0.0017 & * & 0 \\
\hline $0.4 \mathrm{mM}$ oleic acid & 24 & 12 & 82 & 5 & 0.0000 & $* * *$ & 0 \\
\hline $1 \mu \mathrm{g} \mathrm{hPPAR} \gamma$ & 24 & 4 & 66 & 8 & 0.0081 & ** & \\
\hline $0.4 \mathrm{mM}$ oleic acid $+1 \mu \mathrm{g} \mathrm{hPPAR} \gamma$ & 24 & 4 & 26 & 4 & 0.0000 & $* * *$ & \\
\hline $0.2 \mathrm{mM}$ oleic acid $+0.2 \mathrm{mM}$ palmitic acid & 24 & 12 & 114 & 24 & 0.5715 & & \\
\hline $1 \mu \mathrm{g} \mathrm{hPPAR} \gamma$ & 24 & 6 & 95 & 12 & 0.6798 & & \\
\hline $\begin{array}{l}0.2 \mathrm{mM} \text { oleic acid }+0.2 \mathrm{mM} \text { palmitic acid }+1 \mu \mathrm{g} \\
\text { hPPAR } \gamma\end{array}$ & 24 & 6 & 36 & 2 & 0.0000 & $\star \star \star *$ & \\
\hline $0.4 \mathrm{mM}$ linoleic acid & 24 & 10 & 65 & 7 & 0.0003 & $* * *$ & O \\
\hline $1 \mu \mathrm{g}$ hPPAR $\gamma$ & 24 & 6 & 61 & 4 & 0.0000 & $* * *$ & \\
\hline $0.4 \mathrm{mM}$ linoleic acid $+1 \mu \mathrm{g}$ hPPAR $\gamma$ & 24 & 6 & 24 & 3 & 0.0000 & $* * *$ & \\
\hline $0.4 \mathrm{mM}$ linolenic acid & 24 & 10 & 46 & 4 & 0.0000 & $* \star *$ & 0 \\
\hline $1 \mu \mathrm{g}$ hPPAR $\gamma$ & 24 & 6 & 91 & 4 & 0.0503 & * & \\
\hline $0.4 \mathrm{mM}$ linolenic acid $+1 \mu \mathrm{g}$ hPPAR $\gamma$ & 24 & 6 & 42 & 19 & 0.0115 & & \\
\hline $10 \mu \mathrm{M} \mathrm{H}_{2} \mathrm{O}_{2}$ & 24 & 15 & 83 & 2 & 0.0000 & $* * *$ & O \\
\hline $33 \mu \mathrm{M} \mathrm{H}_{2} \mathrm{O}_{2}$ & 24 & 15 & 71 & 2 & 0.0000 & $* * *$ & 0 \\
\hline TRB3 & 24 & 12 & 277 & 17 & 0.0000 & $* * *$ & 0 \\
\hline
\end{tabular}

Table 1. Effect of different treatments on basal glucagon gene transcription. Effect ( $\%$ control) values were calculated taking as $100 \%$ the basal value in the absence of insulin. $t=$ duration of treatment; $n=$ number of dishes; SEM = standard error of the mean; $p=$ Student $t$-test; ${ }^{*} p<0.05 ;{ }^{* *} p<0.01 ;{ }^{* * *} p<0.001$. Grey dots on the right side indicate substances that modified basal glucagon gene transcription in a novel and meaningful way. 


\begin{tabular}{|c|c|c|c|c|c|}
\hline Treatment & $t(h)$ & $n$ & $I C_{50}(n M)$ & $\begin{array}{c}\text { Insulin } \\
E_{\max } \\
\end{array}$ & \\
\hline- & 23 & 10 & 0.37 & 100 & \\
\hline $10 \mathrm{ng} / \mathrm{ml}$ TNF $\alpha$ & 24 & 8 & 0.69 & 113 & \\
\hline $10 \mathrm{ng} / \mathrm{ml}$ TNF $\alpha$ & 46 & 6 & 0.22 & 107 & \\
\hline $100 \mathrm{ng} / \mathrm{ml}$ TNF $\alpha$ & 24 & 4 & 0.28 & 117 & \\
\hline $20 \mathrm{ng} / \mathrm{ml}$ Interleukin 6 & 24 & 6 & 0.17 & 103 & \\
\hline $20 \mathrm{ng} / \mathrm{ml}$ Interleukin 6 & 46 & 6 & 0.12 & 101 & \\
\hline $10 \mathrm{ng} / \mathrm{ml}$ IL-1 $\beta$ & 24 & 6 & 0.20 & 27 & 0 \\
\hline $1 \mathrm{mM} 8 \mathrm{BrcAMP}$ & 24 & 8 & 0.35 & 68 & \\
\hline $1 \mathrm{mM} 8 \mathrm{BrcAMP}$ & 44 & 6 & 0.40 & 82 & \\
\hline $1 \mu \mathrm{M}$ Dexamethasone & 24 & 6 & 0.36 & 95 & \\
\hline $1 \mu \mathrm{M}$ Dexamethasone & 46 & 8 & 0.51 & 112 & \\
\hline 300 nM Cyclosporin A & 24 & 6 & 0.29 & 76 & \\
\hline 300 nM Cyclosporin A & 46 & 4 & 0.15 & 124 & \\
\hline $10 \mathrm{nM}$ Tacrolimus & 24 & 4 & 0.07 & 87 & \\
\hline 10 nM Tacrolimus & 46 & 6 & 0.48 & 97 & \\
\hline $1 \mu \mathrm{g} \mathrm{hPPAR} \gamma$ †† & 24 & 34 & - & 82 & \\
\hline $0.2 \mathrm{mM}$ palmitic acid $\dagger$ & 24 & 6 & 0.36 & 105 & \\
\hline $0.2 \mathrm{mM}$ stearic acid $\dagger$ & 24 & 6 & 0.27 & 104 & \\
\hline $0.4 \mathrm{mM}$ oleic acid $\dagger$ & 24 & 8 & 0.30 & 113 & \\
\hline $0.2 \mathrm{mM}$ oleic acid $+0.2 \mathrm{mM}$ palmitic acid $\dagger$ & 24 & 6 & 0.34 & 143 & \\
\hline $0.4 \mathrm{mM}$ linoleic acid $†$ & 24 & 4 & 0.07 & 76 & \\
\hline $0.4 \mathrm{mM}$ linolenic acid $†$ & 24 & 4 & 0.17 & 115 & \\
\hline $10 \mu \mathrm{M} \mathrm{H}_{2} \mathrm{O}_{2}$ & 24 & 15 & - & 100 & \\
\hline $33 \mu \mathrm{M} \mathrm{H}_{2} \mathrm{O}_{2}$ & 24 & 15 & - & 102 & \\
\hline TRB3 & 24 & 12 & - & - & \\
\hline $100 \mathrm{nM}$ insulin (chronic insulin) & 46 & 8 & - & 0 & 0 \\
\hline
\end{tabular}

Table 2. Effect of different treatments on the insulin-mediated inhibition of glucagon gene transcription. $I_{50}$ and insulin $E_{\max }$ for different substances. Insulin $E_{\max }$ values: the maximal inhibition of glucagon gene transcription by insulin in the otherwise untreated group (run in parallel as control) was set as $100 \% . \quad \mathrm{IC}_{50}$ values are reported as the concentration reading the half maximal effect. $t=$ duration of treatment; $n=$ number of dishes; $I_{50}=(n M) . \dagger$ : refers to experiments with seven insulin concentrations; $\dagger \dagger$ : refers to experiments with three insulin concentrations. $\mathrm{IC}_{50}$ values for the last four treatments in the table are not shown since the experiments contain only single insulin concentrations. Grey dots on the right side indicate substances that reversed the insulin-induced inhibition of glucagon gene transcription and were further analyzed in the present work. 


\subsection{Further characterization of the effect of TNFa and PPARy on glucagon gene transcription}

\subsubsection{TNFa}

As shown in the previous section, high concentrations of TNF $\alpha$ inhibited basal glucagon gene transcription; therefore, further experiments were performed to address the question whether TNF $\alpha$ influences also stimulated glucagon gene transcription. $41 \mathrm{~h}$ after transfection, InR1G9 cells were treated with $100 \mathrm{ng} / \mathrm{ml}$ TNF $\alpha$ followed $1 \mathrm{~h}$ later by stimulation with: 1) potassium chloride $(\mathrm{KCl})$ [40 $\mathrm{mM}$ ], which induces membrane depolarization, 2) phorbol 12-myristate 13-acetate (TPA) [300 nM], a phorbol ester capable of activating protein kinase $\mathrm{C}$ (PKC) or 3 ) forskolin [10 $\mu \mathrm{M}]$ which elevates cAMP by activating adenylate cyclase. TNF $\alpha$ inhibited basal glucagon gene transcription by $30 \%$. TNF $\alpha$ was able to inhibit the stimulation of glucagon gene transcription caused by any of the substances mentioned above (Figure 32).

\subsubsection{PPARy}

PPAR $\gamma$ in the absence of a ligand inhibited glucagon gene transcription by $31 \%$ (Table 1 ). Therefore, it was of interest to study the effect of co-transfection of PPAR $\gamma$ in the presence of the synthetic PPAR $\gamma$ ligand rosiglitazone. PPAR $\gamma$ plus treatment for $46 \mathrm{~h}$ with rosiglitazone inhibited basal glucagon gene transcription by $50 \%$ (Figure $33 \mathrm{~A}$ ). In the presence of insulin, PPAR $\gamma$ plus rosiglitazone slightly reversed the insulin-inhibitory effect on glucagon gene transcription (Figure $33 \mathrm{~B}$ ). Increasing the duration of rosiglitazone treatment to $120 \mathrm{~h}$ (plus PPAR $\gamma$ co-transfection) inhibited basal glucagon gene transcription by $40 \%$ (Figure $34 \mathrm{~A}$ ). As observed for the $46 \mathrm{~h}$ experiments in the presence of insulin, longer exposure to rosiglitazone (plus PPAR $\gamma$ co-transfection) slightly reversed the insulin-mediated inhibition of glucagon gene transcription (Figure $34 \mathrm{~B}$ ). 


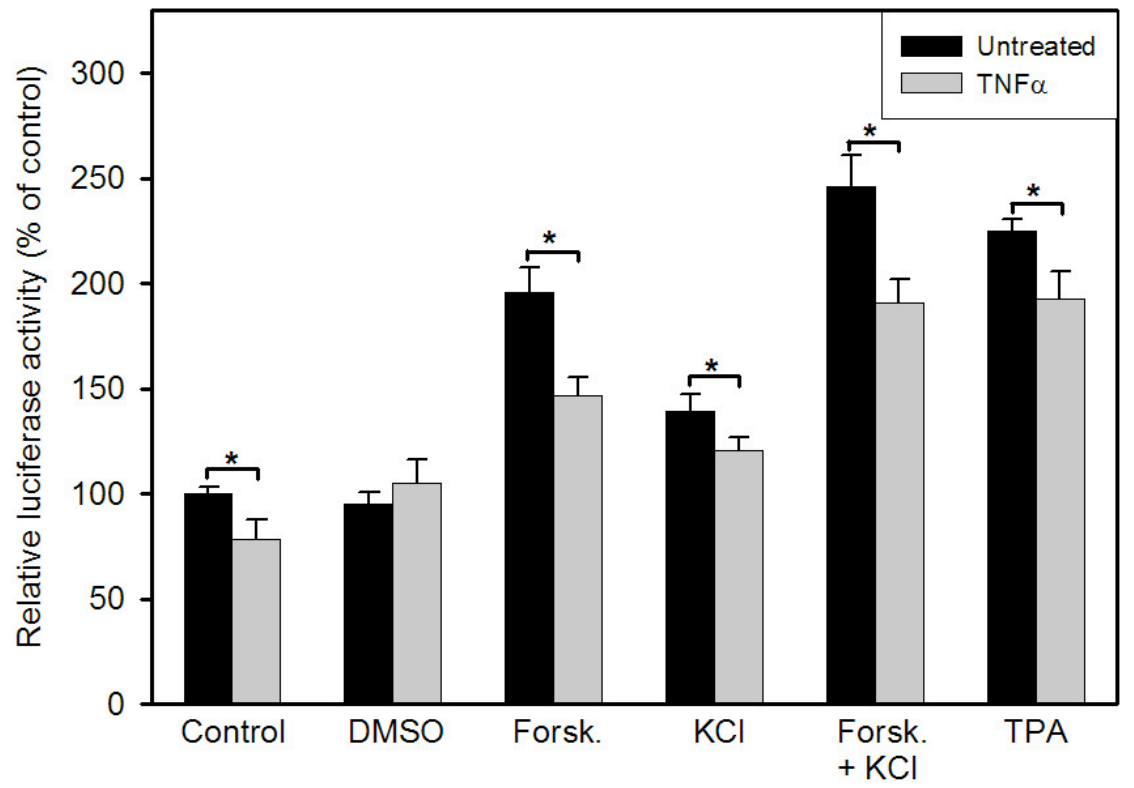

Figure 32. Effect of TNFa treatment on stimulated glucagon gene transcription. InR1G9 cells were transfected with $2.0 \mu \mathrm{g} /$ dish of the $-350 \mathrm{GluLuc}$ reporter plasmid and $0.5 \mu \mathrm{g} / \mathrm{dish}$ of the pGFPtpz-cmv[R] plasmid. $41 \mathrm{~h}$ after transfection, $100 \mathrm{ng} / \mathrm{ml}$ TNF $\alpha$ was added to the cells. $1 \mathrm{~h}$ later, cells were treated with the following substances: Phorbol 12-myristate 13-acetate (TPA, 300 $\mathrm{nM}$ ), forskolin (Forsk., $10 \mu \mathrm{M})$, potassium chloride (KCl) $(40 \mathrm{mMT})$ or forskolin (Forsk., $10 \mu \mathrm{M})$ plus $\mathrm{KCl}(40 \mathrm{mM}) .6 \mathrm{~h}$ after treatment with these substances, cells were harvested and cell extracts were prepared for luciferase and GFP assays. Values were normalized to the untreated group (no $\mathrm{TNF} \alpha$, no other treatment). Values show the mean + / - SEM of three independent experiments performed in triplicate. Statistical analysis was performed by paired Student t-test. ${ }^{*} p<0.05$.

†: the concentration of $\mathrm{KCl}$ in RPMI 1640 medium is $5 \mathrm{mM}$, therefore with the addition of $40 \mathrm{mM} \mathrm{KCl}$ to this experiment, a final $\mathrm{KCl}$ concentration of $45 \mathrm{mM}$ was obtained. 


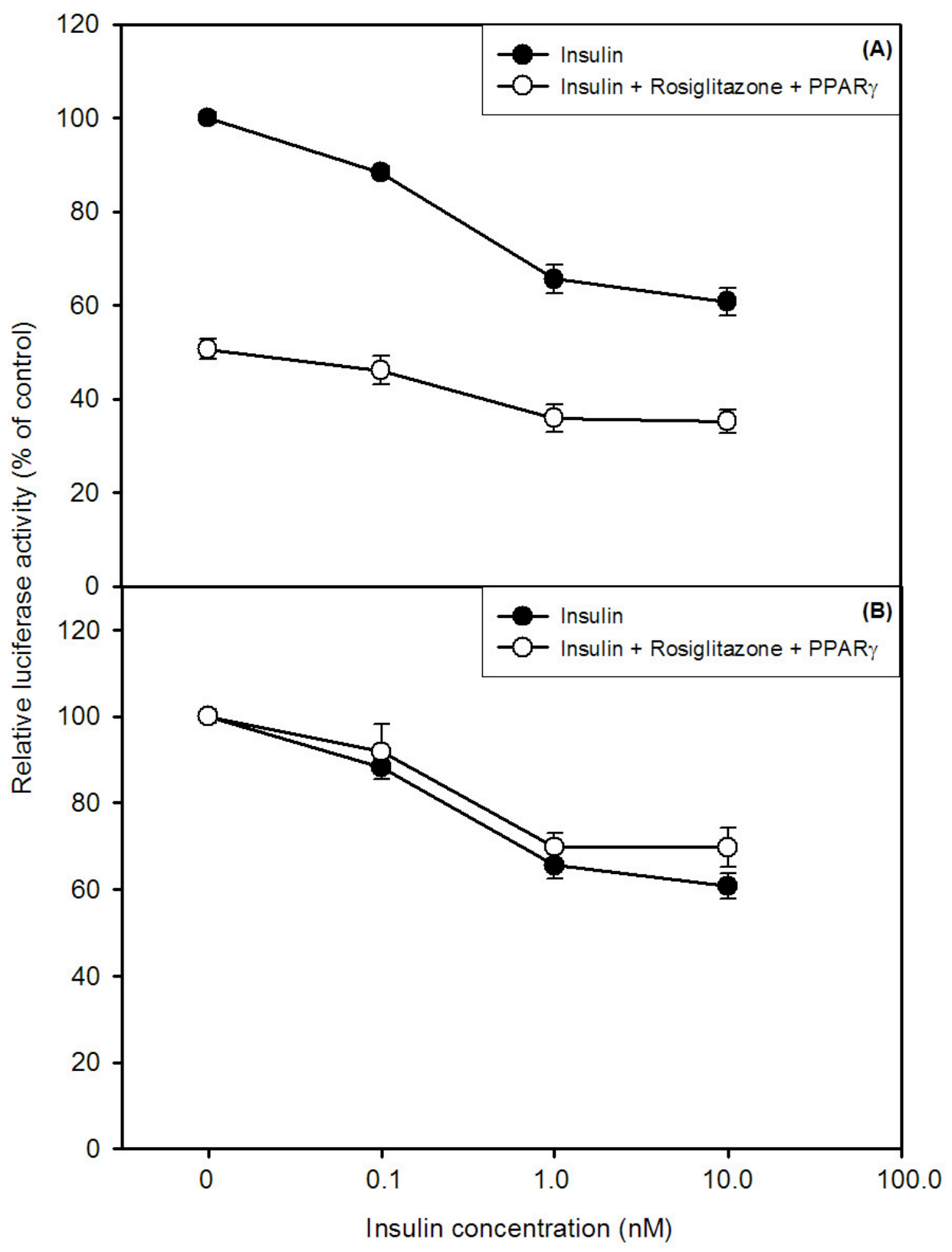

Figure 33. Effect of PPARy co-transfection and $46 \mathrm{~h}$ treatment with rosiglitazone on basal and insulin-mediated inhibition of glucagon gene transcription. InR1G9 cells were transfected with $2.0 \mu \mathrm{g} /$ dish of the $-350 \mathrm{GluLuc}, 0.5 \mu \mathrm{g} /$ dish of the pGFPtpz-cmv[R] plasmid, and $1 \mu \mathrm{g} / \mathrm{dish}$ of the hPPAR $\gamma$ plasmid. To maintain a constant amount of DNA pBluescript (Stratagene, La Jolla) was added. $2 \mathrm{~h}$ after transfection, cells were treated with $50 \mu \mathrm{M}$ rosiglitazone. $24 \mathrm{~h}$ after transfection, cells were washed with PBS and the medium was replaced with a medium containing $0.5 \% \mathrm{BSA}$; immediately $50 \mu \mathrm{M}$ rosiglitazone was added to the cells. $1 \mathrm{~h}$ later, cells were treated with increasing insulin concentrations. $48 \mathrm{~h}$ after transfection cells were harvested and luciferase and GFP activities were measured. A) Values were normalized to the untreated group (no insulin, no rosiglitazone, no PPAR $\gamma$ ). B) Values were normalized to the respective group not treated with insulin. Values show the mean $+/$ - SEM of three independent experiments performed in quadruplicate. 


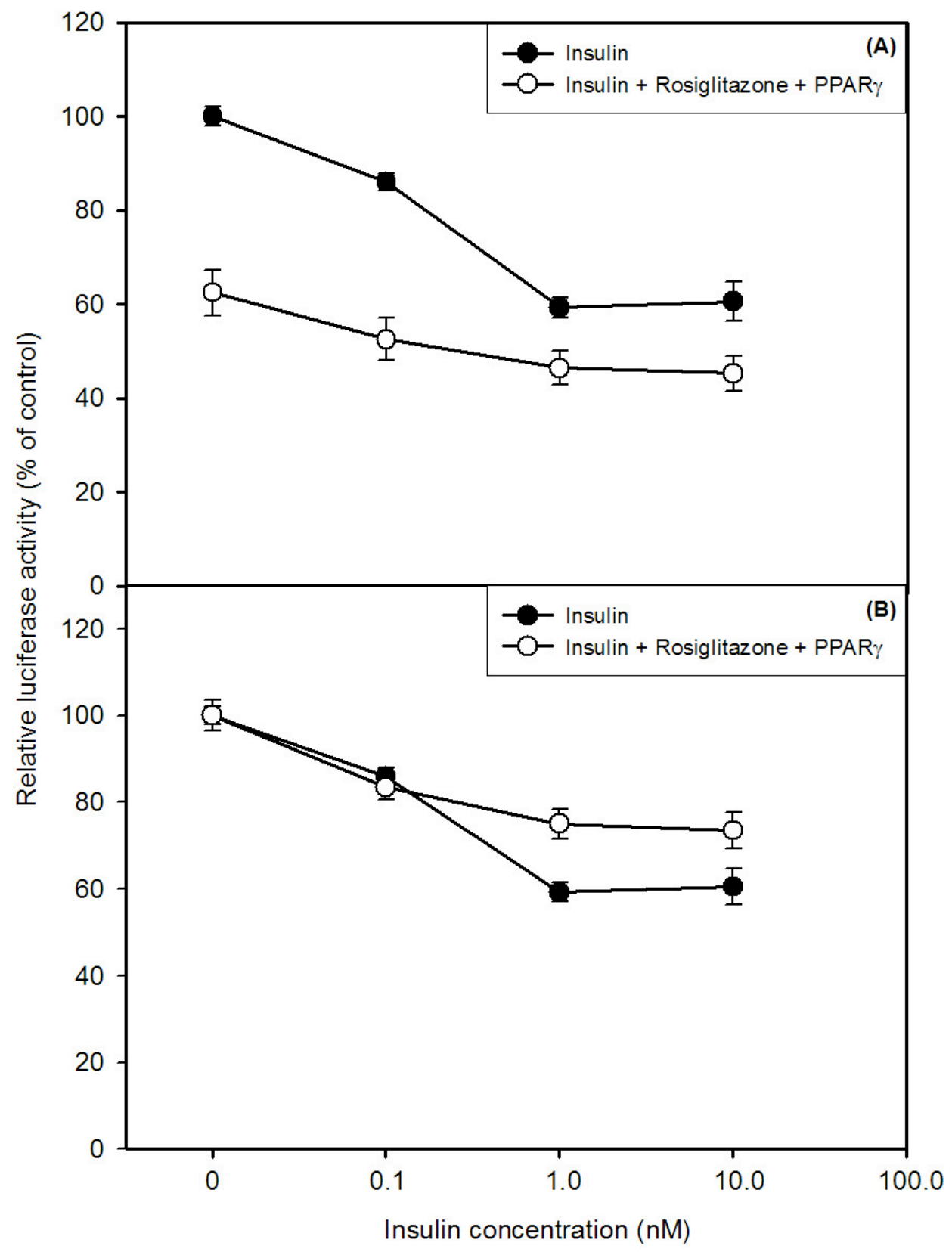

Figure 34. Effect of PPAR y co-transfection and $120 \mathrm{~h}$ treatment with rosiglitazone on basal and insulin-mediated inhibition of glucagon gene transcription. InR1G9 cells were treated with $50 \mu \mathrm{M}$ rosiglitazone one splitting step before being transfected (72 $\mathrm{h}$ ahead of transfection). Cells were then transfected with $2.0 \mu \mathrm{g} /$ dish of the $-350 \mathrm{GluLuc}, 0.5 \mu \mathrm{g} /$ dish of the pGFPtpz-cmv[R] plasmid, and $1 \mu \mathrm{g} /$ dish of the hPPAR $\gamma$ plasmid. To maintain a constant amount of DNA pBluescript (Stratagene, La Jolla) was added. $2 \mathrm{~h}$ after transfection, cells were treated with $50 \mu \mathrm{M}$ rosiglitazone. $24 \mathrm{~h}$ after transfection, cells were washed with PBS and the medium was replaced with a medium containing $0.5 \% \mathrm{BSA}$; immediately $50 \mu \mathrm{M}$ rosiglitazone was added to the cells. $1 \mathrm{~h}$ later, cells were treated with increasing insulin concentrations. $48 \mathrm{~h}$ after transfection cells were harvested and luciferase and GFP activities were measured. A) Values were normalized to the untreated group (no insulin, no rosiglitazone, no PPAR $\gamma$ ). B) Values were normalized to the respective group not treated with insulin. Values show the mean $+/$ - SEM of two independent experiments performed in quadruplicate. 


\subsection{Further characterization of the blockade by chronic insulin treatment and IL-1及 of the insulin-induced inhibition of glucagon gene transcription}

\subsubsection{Chronic insulin treatment}

In contrast to insulin treatment for $23 \mathrm{~h}$, insulin treatment for $46 \mathrm{~h}$ did not inhibit glucagon gene transcription (Figure 31, see also Figure 35). It was investigated at which step in the insulin signaling pathway to the glucagon gene the response was lost under chronic insulin treatment.

\subsubsection{PKB phosphorylation, expression and action}

The effect of chronic insulin treatment in combination with the constitutively active form of protein kinase $\mathrm{B}\left(\mathrm{PKB}_{\mathrm{myr}}\right)$ or with the kinase-dead form $\mathrm{PKB}_{\mathrm{myr}}-\mathrm{K} 179 \mathrm{M}$ was studied. In the absence of insulin, $\mathrm{PKB}_{\text {myr }}$ was able to inhibit glucagon gene transcription by $32 \%$ (Figure 35). The inhibitory effect of PKB was not observed in the experiments in which $\mathrm{PKB}_{\text {myr }}$ $\mathrm{K} 179 \mathrm{M}$ was used. Upon a $23 \mathrm{~h}$ treatment with insulin, $\mathrm{PKB}_{\mathrm{myr}}$ could not further inhibit glucagon gene transcription (Figure 35). Insulin treatment for $46 \mathrm{~h}$ no longer inhibited glucagon gene transcription. Under this chronic treatment, $\mathrm{PKB}_{\mathrm{myr}}$ was still able to inhibit glucagon gene transcription, while $\mathrm{PKB}_{\text {myr }}-\mathrm{K} 179 \mathrm{M}$ did not cause any inhibition (Figure 35).

Under the prolonged insulin treatment, $\mathrm{PKB}_{\text {myr }}$ was still able to inhibit glucagon gene transcription. PKB expression and its insulin-induced phosphorylation on serine 473 (Ser 473) were analyzed next. Cell lysates were prepared from InR1G9 cells treated with 100 $\mathrm{nM}$ insulin for either $23 \mathrm{~h} 10 \mathrm{~min}$ or for only $10 \mathrm{~min}$. These lysates were evaluated by immunoblot using antibodies against Ser 473-phosphorylated PKB or against PKB. Upon extended insulin treatment, Ser 473-phosphorylation was significantly reduced (upper blot and panel Figure $36 \mathrm{~A}$ and Figure $36 \mathrm{~B}$, respectively) while PKB levels remained unaffected (lower blot and panel Figure $36 \mathrm{~A}$ and Figure $36 \mathrm{~B}$, respectively). 


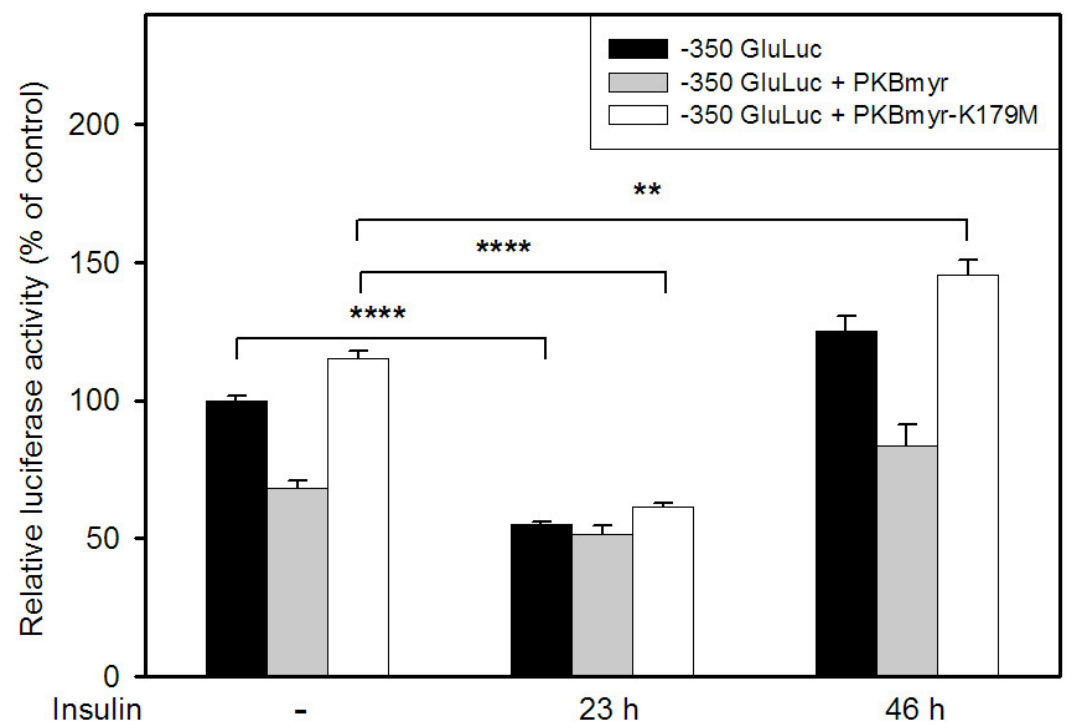

Figure 35. Effect of PKB on glucagon gene transcription with or without a $23 \mathrm{~h}$ or $\mathbf{4 6} \mathrm{h}$ insulin treatment. InR1G9 cells were transfected with $2.0 \mu \mathrm{g} /$ dish of the -350 GluLuc reporter plasmid, 0.5 $\mu \mathrm{g} /$ dish of the pGFPtpz-cmv[R] plasmid, $2.0 \mu \mathrm{g} /$ dish of the myristylated PKB (PKB dish of the mutated PKB plasmid (PKB myr $-\mathrm{K} 179 \mathrm{M}) .2 \mathrm{~h}$ after transfection, cells were treated with 100 $\mathrm{nM}$ insulin. $20 \mathrm{~h}$ later, cells were washed with PBS and the medium was changed for a medium containing $0.5 \%$ BSA. Immediately, $100 \mathrm{nM}$ insulin was added to the cells. $1 \mathrm{~h}$ later, cells were treated with $10 \mathrm{nM}$ insulin. $48 \mathrm{~h}$ after transfection cells were harvested and luciferase and GFP activities were measured. Values were normalized to the untreated group (no insulin) and show the mean $+/$ - SEM of three independent experiments performed in triplicate. Statistical analysis was performed by one way-ANOVA followed by Scheffe test ${ }^{* * *} p<0.00005 ;{ }^{* *} p<0.005$. 
(A)

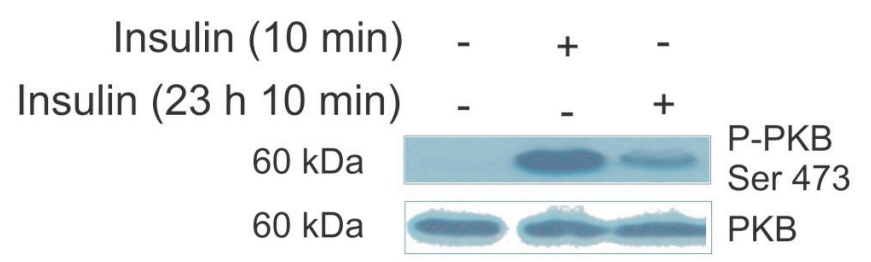

(B)

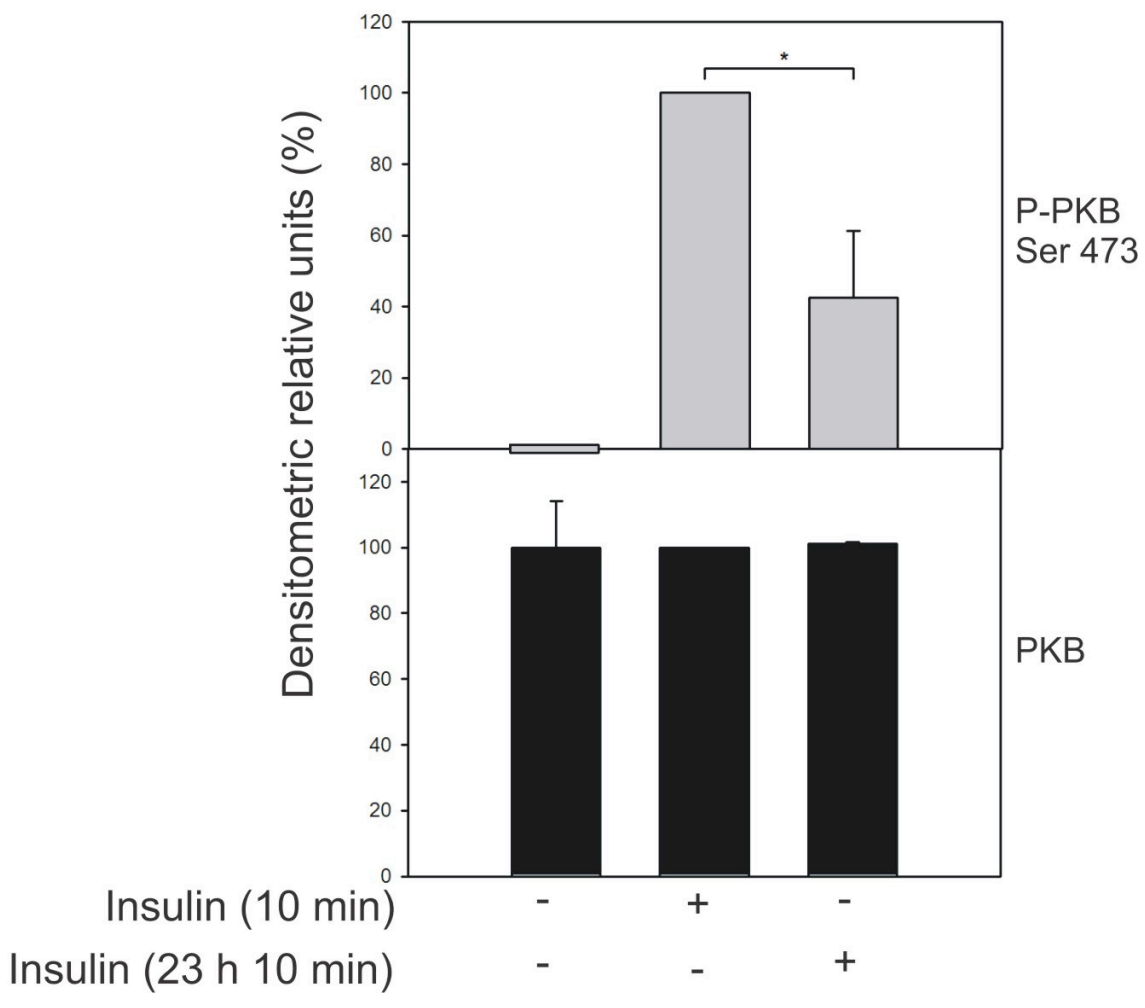

Figure 36. Effect of an extended insulin exposure on PKB Ser 473-phosphorylation and PKB expression. $2 \mathrm{~h}$ after plating the cells in medium containing serum, the cells were treated with 100 $\mathrm{nM}$ insulin (column insulin $23 \mathrm{~h} 10 \mathrm{~min}$ ). $22 \mathrm{~h}$ later, cells were washed and the medium was replaced with a medium containing $0.5 \%$ BSA. Immediately, $10 \mathrm{nM}$ insulin was added to the cells in the insulin $23 \mathrm{~h} 10$ min group. $1 \mathrm{~h}$ later, cells in the 10 min insulin group were treated with $10 \mathrm{nM}$ insulin. A) Representative immunoblot for Ser 473-phosphorylated PKB and PKB. B) Densitometric analysis. Analysis was performed using the Biometra Bio Doc Analyze 2.0 program. Densitometric values were normalized to the $10 \mathrm{~min}$ insulin group (upper panel Fig. $36 \mathrm{~B}$, lane insulin $10 \mathrm{~min}$ ) and to the untreated group (lower panel Fig. 36 B, untreated lane). The figure shows the mean + / SEM of four independent experiments. Statistical analysis was performed by paired Student t-test. ${ }^{*} \mathrm{p}<0.05$. 


\subsubsection{Expression and autophosphorylation of the insulin receptor}

Analysis of PKB expression and phosphorylation upon chronic insulin treatment indicated that an upstream target of PKB, within the insulin-signaling pathway was being affected. Therefore, autophosphorylation of the insulin receptor at tyrosine residues $1150 / 1151$, an early event in insulin signaling, was studied. Cell lysates of cells either treated with $100 \mathrm{nM}$ insulin for 10 minutes or for 23 h $10 \mathrm{~min}$, were analyzed by immunoblotting. For this analysis antibodies against Tyr $1150 / 1151$ phosphorylated insulin receptor or against the beta subunit of the insulin receptor were used. While $10 \mathrm{~min}$ insulin treatment resulted in a strong phosphorylation, extended insulin exposure abolished insulin receptor autophosphorylation completely (upper blot and panel Figure 37 A and Figure 37 B, respectively). In addition, insulin receptor levels were reduced upon $23 \mathrm{~h} 10$ min insulin treatment by $90 \%$ (lower blot and panel Figure $37 \mathrm{~A}$ and Figure $37 \mathrm{~B}$, respectively). 
(A)

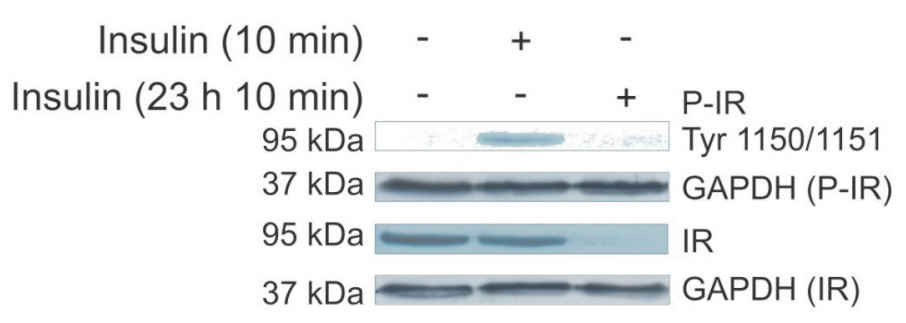

(B)

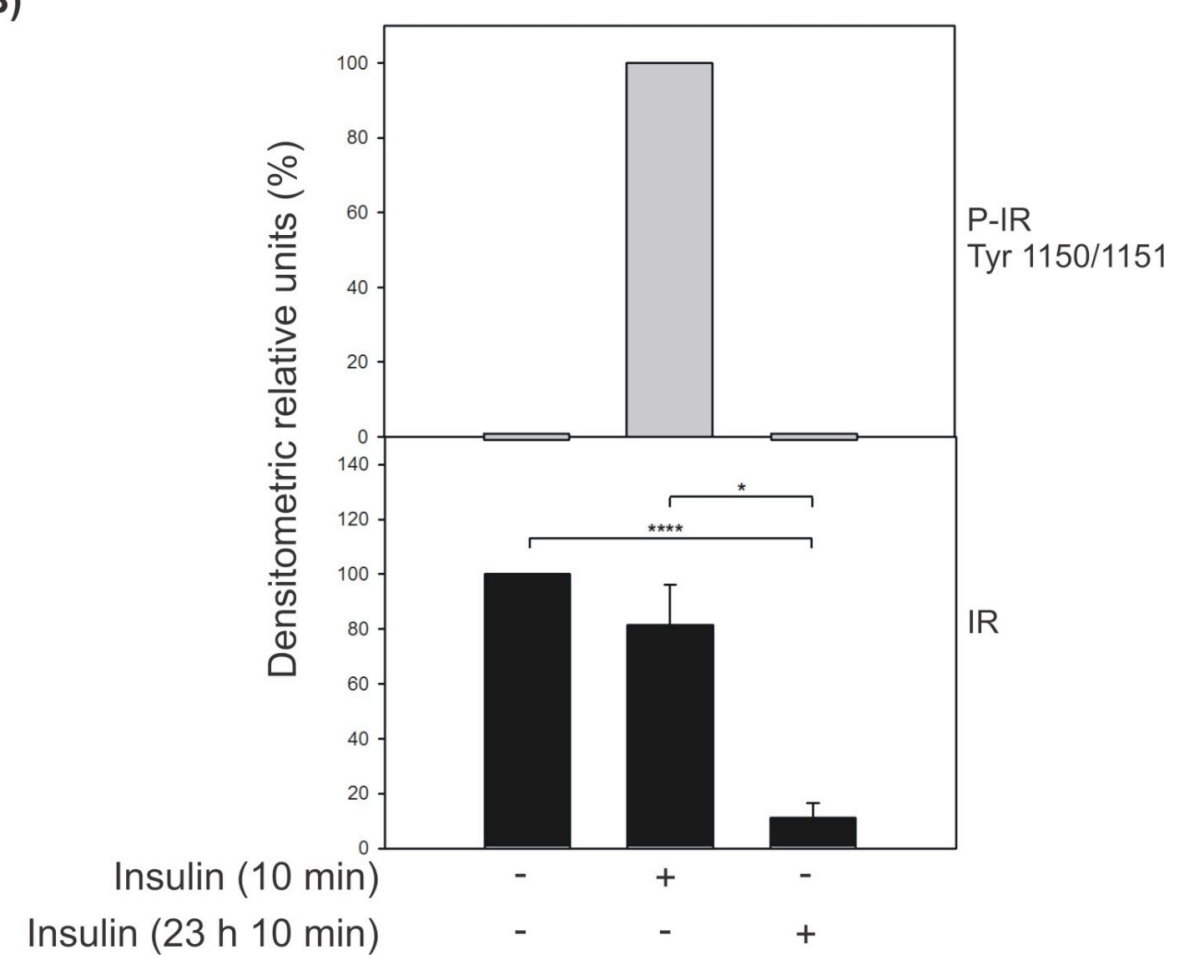

Figure 37. Effect of an extended insulin exposure on insulin receptor autophosphorylation (on Tyr 1150 / 1151) and expression. $2 \mathrm{~h}$ after plating the cells in medium containing serum, cells were treated with $100 \mathrm{nM}$ insulin. $22 \mathrm{~h}$ later, cells were washed with PBS and the medium was replaced with a medium containing $0.5 \%$ BSA. Cells in the 23 h 10 min insulin group were immediately treated with $100 \mathrm{nM}$ insulin. $1 \mathrm{~h}$ later, the 10 min insulin group was treated with $10 \mathrm{nM}$ insulin for additional $10 \mathrm{~min}$. A) Representative immunoblot for phosphorylated insulin receptor on Tyr $1150 / 1151$ and for the insulin receptor. B) Densitometric analysis. Analysis was performed using the Biometra Bio Doc Analyze 2.0 program. Densitometric values were normalized to the 10 min insulin group (upper panel Fig. $37 \mathrm{~B}$, second lane from the left) and to the untreated group (lower panel Fig. $37 \mathrm{~B}$, first lane from the left). Phosphorylated insulin receptor as well as insulin receptor values were also normalized to GAPDH. Densitometric values show the mean + / - SEM of three independent experiments. Statistical analysis was performed by paired Student t-test. ${ }^{* * * *} p<0.0000005 ;{ }^{*} p<0.05$. 


\subsubsection{Time course of insulin receptor disappearance}

Previous results showed that upon a 23 h 10 min insulin treatment, insulin receptor expression levels were significantly reduced (Figure 37). In order to determine whether at earlier times there was a decrease in phosphorylation independent of a reduction in insulin receptor expression level, a time-course experiment was performed. Cells were treated with $100 \mathrm{nM}$ insulin for different times and phosphorylation and insulin receptor levels were analyzed (Figure 38). The insulin receptor autophosphorylation was gradually reduced $4 \mathrm{~h}$ after insulin exposure, while upon $24 \mathrm{~h}$ insulin exposure the autophosphorylation was completely abolished (upper blot and graph of Figure 38 A and Figure 38 B, respectively). Insulin receptor expression levels showed a gradual decrease starting $2 \mathrm{~h}$ after insulin treatment. Insulin treatment for 8 and $24 \mathrm{~h}$ completely abolished insulin receptor expression levels (lower blot and panel Figure $38 \mathrm{~A}$ and Figure $38 \mathrm{~B}$, respectively).

\subsubsection{Insulin receptor recovery after insulin withdrawal}

To study whether the decreased level of insulin receptor could be recovered upon insulin withdrawal cells were cultured in medium containing $10 \%$ fetal bovine serum. Then different recovery periods were studied in medium containing $10 \%$ FBS or in medium containing $10 \%$ FBS followed by a recovery period in a medium containing $5 \%$ BSA (without insulin). Cells were treated for different times with insulin and then insulin was removed from the medium allowing the cells to have recovery periods of 6,12 or $24 \mathrm{~h}$ (Figure 39). After the withdrawal of insulin, insulin receptor expression levels recovered (Figure 40). The recovery did not differ between both types of culture media. After a $24 \mathrm{~h}$ recovery period, $60 \%$ to $85 \%$ of the insulin receptor was detected (Figure 40 ). 
(A)

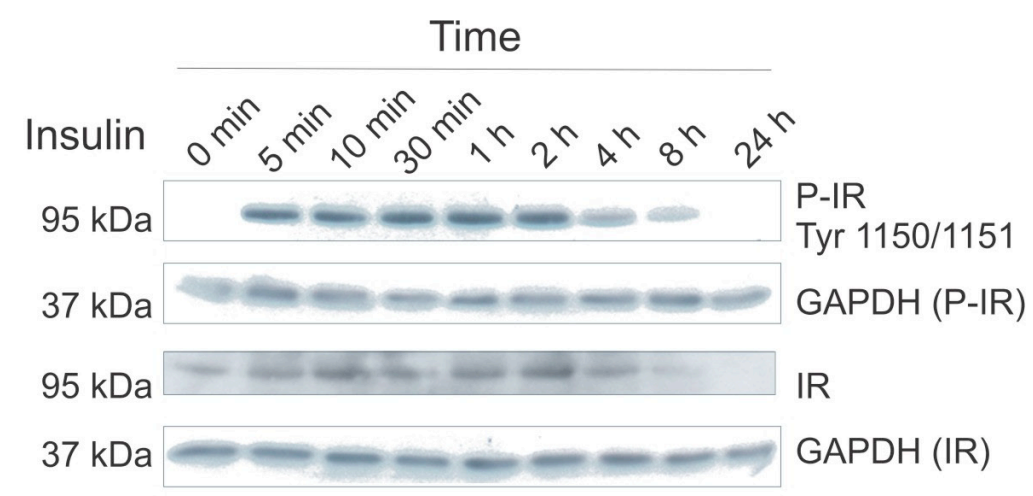

(B)

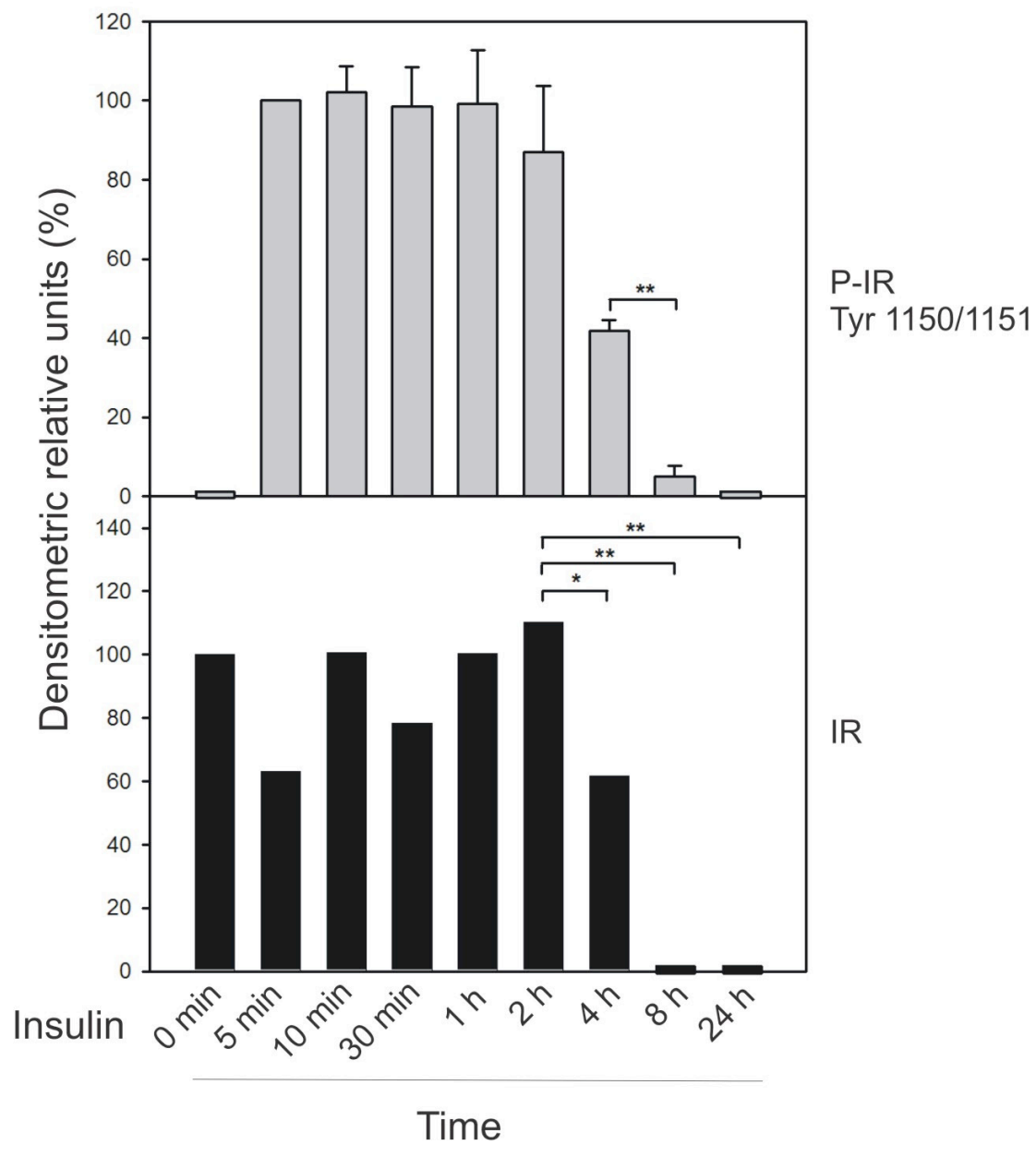

Figure 38. Kinetics for insulin receptor autophosphorylation and expression. Cells were plated in medium containing serum. $2 \mathrm{~h}$ after plating, the cells were treated with $100 \mathrm{nM}$ insulin (24 $\mathrm{h}$ insulin group). The following treatments were performed at the indicated times. A) Representative immunoblot for Tyr $1150 / 1151$ phosphorylated insulin receptor and insulin receptor. B) Densitometric analysis. Analysis was performed using the Biometra Bio Doc Analyze 2.0 program. Densitometric values were normalized to the 5 min insulin group (upper panel Fig. $33 \mathrm{~B}$, second lane from the left) and to the untreated group (lower panel Fig. $33 \mathrm{~B}$, first lane from the left). IR values were also normalized to GAPDH. Densitometric values show the mean + / - SEM of four independent experiments. Statistical analysis was performed by paired Student $t$-test. ${ }^{* *} p<0.005$; ${ }^{*} \mathrm{p}<0.05$. 

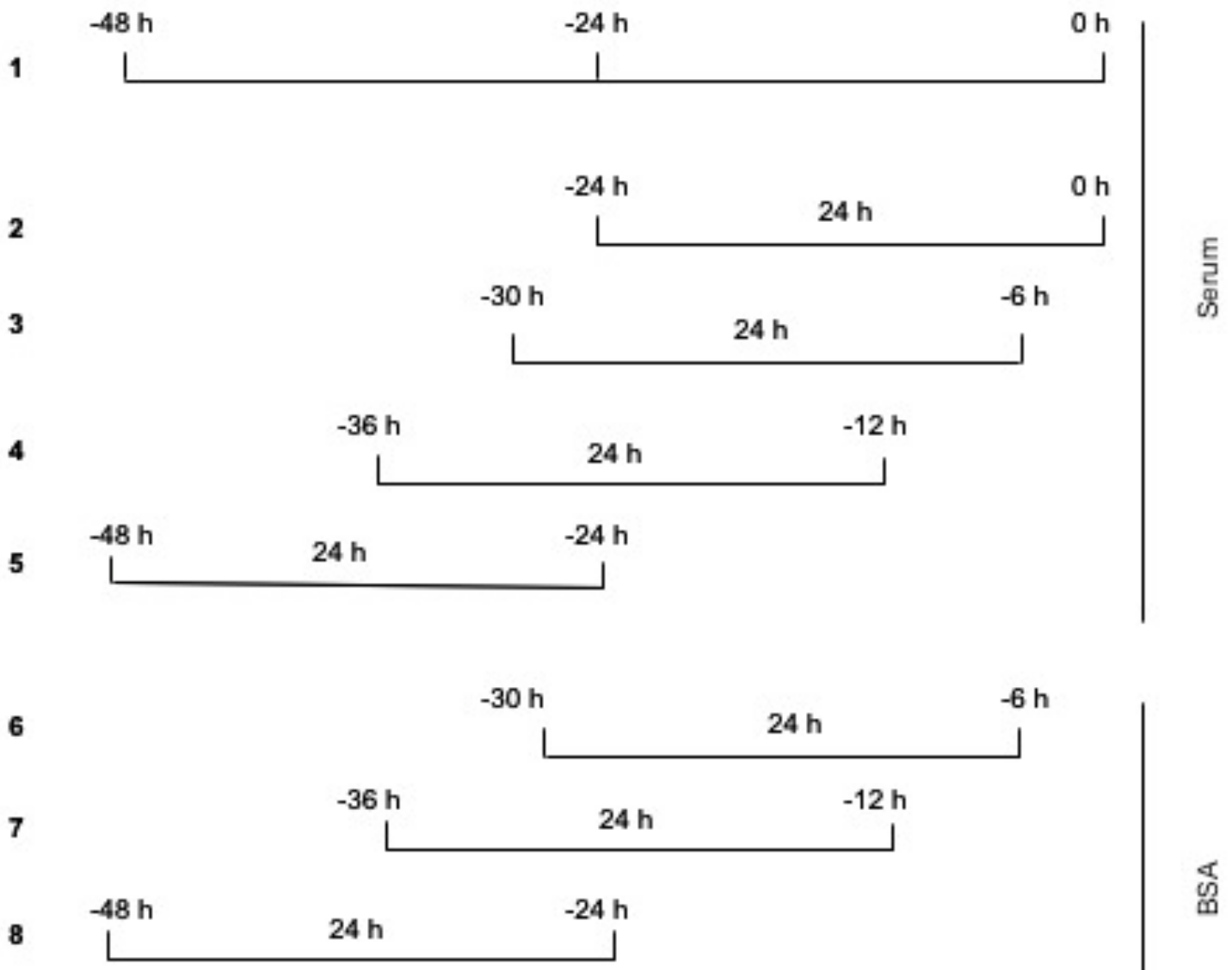

Figure 39. Timeline for recovery of the expression levels of the insulin receptor. Cells were plated in medium containing $10 \%$ fetal bovine serum (FBS). At the indicated times cells were treated with $100 \mathrm{nM}$ insulin. $24 \mathrm{~h}$ after treatment the insulin was withdrawn from the medium. The medium was replaced for medium containing $10 \%$ serum for groups 1 to 5 and for medium containing $5 \%$ bovine serum albumin (BSA) for groups 6 to 8 . Recovery periods of 6,12 or $24 \mathrm{~h}$ followed insulin withdrawal. 
(A)

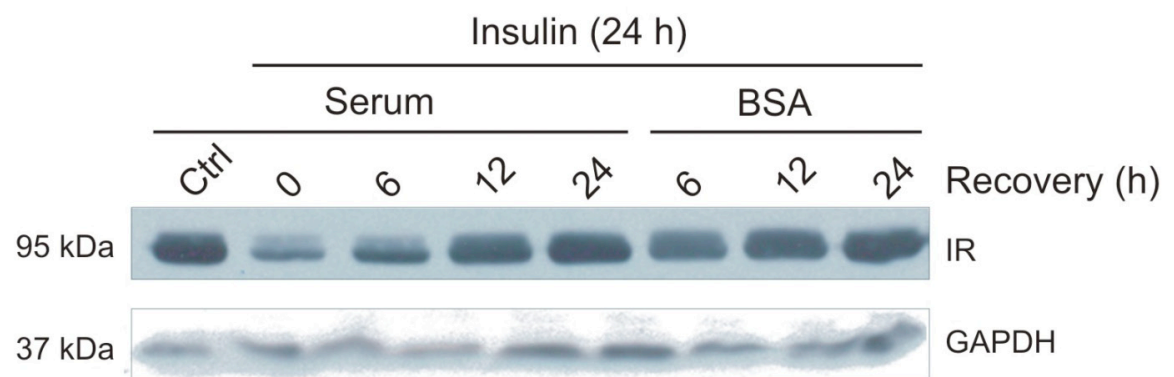

(B)

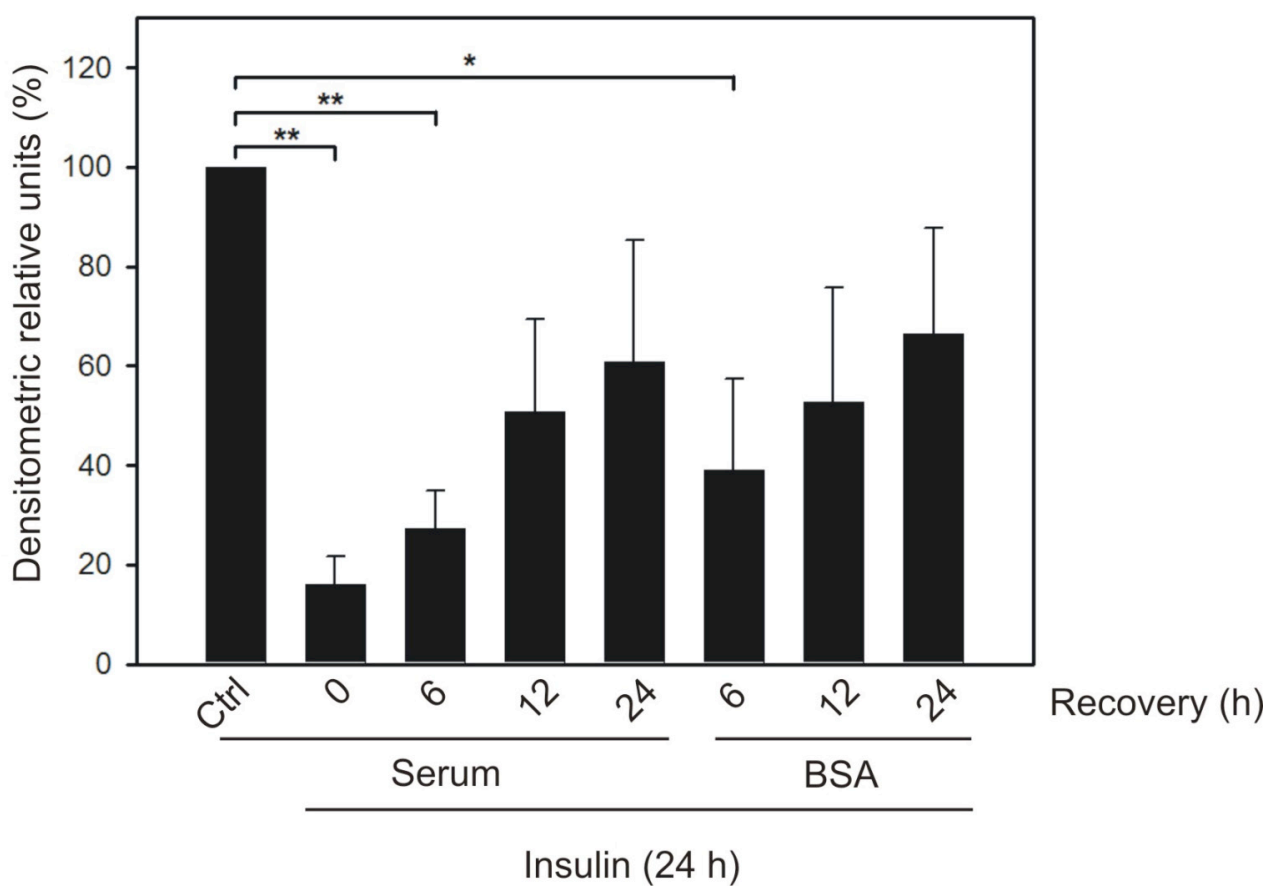

Figure 40. Recovery kinetics for the insulin receptor. Cells were plated in medium containing serum. Cells were treated for $24 \mathrm{~h}$ with $100 \mathrm{nM}$ insulin at the indicated time points. After $24 \mathrm{~h}$ insulin treatment, the medium was replaced for a medium containing $10 \%$ fetal bovine serum or for a medium containing $5 \%$ BSA. Recovery periods of 6,12 or $24 \mathrm{~h}$ followed insulin removal. A) Representative immunoblot for the insulin receptor. B) Densitometric analysis. Analysis was performed using the Biometra Bio Doc Analyze 2.0 program. Densitometric values were normalized to the untreated group (Fig. $40 \mathrm{~B}$, first lane from the left). Insulin receptor values were also normalized to GAPDH. Densitometric values show the mean + / - SEM of three independent experiments. Statistical analysis was performed by paired Student t-test. ${ }^{* *} p<0.0005 ;{ }^{*} p<0.05$. 
The recovery was also studied in functional studies. Figure 41 shows the typical insulininhibitory effect on glucagon gene transcription upon a $23 \mathrm{~h}$ insulin treatment. The third column shows the result of a $24 \mathrm{~h}$ insulin treatment followed by a $24 \mathrm{~h}$ recovery (insulin was removed from the medium). The withdrawal of insulin followed by a $24 \mathrm{~h}$ recovery, induced an increase in glucagon gene transcription (Figure 41).

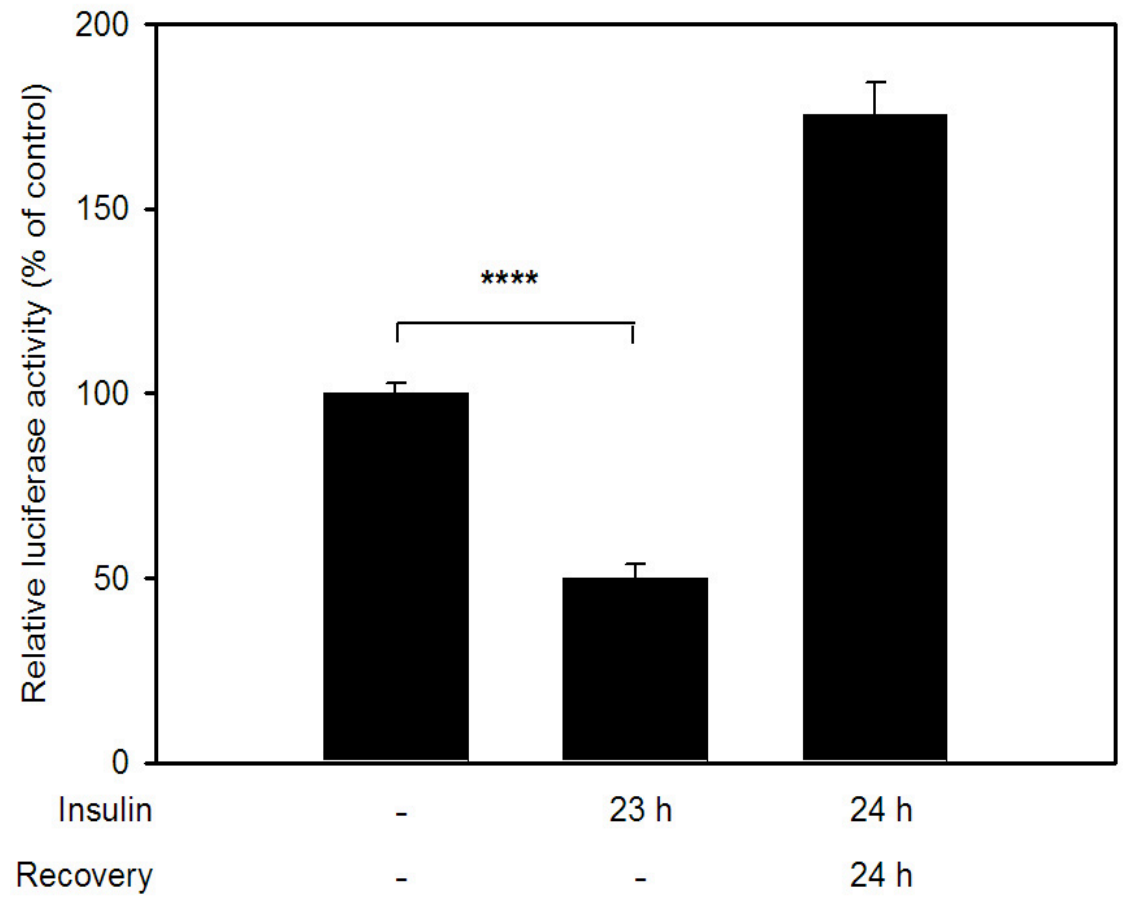

Figure 41. Effect of insulin withdrawal followed by a recovery period on glucagon gene transcription. InR1G9 cells were transfected with $2.0 \mu \mathrm{g} /$ dish of the -350GluLuc reporter plasmid and $0.5 \mu \mathrm{g} /$ dish of the pGFPtpz-cmv[R] plasmid. $2 \mathrm{~h}$ after transfection, cells were treated with 100 $\mathrm{mM}$ insulin ( $24 \mathrm{~h}$ insulin treatment followed by $24 \mathrm{~h}$ recovery). $20 \mathrm{~h}$ later, cells were washed with PBS and the medium was replaced with a medium containing $0.5 \%$ BSA. $1 \mathrm{~h}$ later, $10 \mathrm{nM}$ insulin was added to the cells ( $23 \mathrm{~h}$ insulin). $48 \mathrm{~h}$ after transfection cells were harvested and luciferase and GFP activities were measured. Values were normalized to the untreated group (no insulin) and show the mean +1 - SEM of four independent experiments performed in duplicate. Statistical analysis was performed by one-way ANOVA followed by Scheffe test. ${ }^{* * *} p<0.00005$. 


\subsubsection{Effect of chronic insulin on insulin receptor expression levels in the presence of protein synthesis inhibitors}

To find the cause for decreased insulin receptor expression levels after chronic insulin treatment, experiments with protein synthesis inhibitors were performed. Cycloheximide, an antibiotic that blocks protein and DNA synthesis, was used in order to address whether the decrease in the expression of the insulin receptor after a prolonged treatment of the cells with insulin involved an increase in insulin receptor degradation. Cells were treated with $50 \mu \mathrm{g} / \mathrm{ml}$ cycloheximide in the absence or presence of insulin. When comparing the kinetics for the insulin receptor in the absence or presence of insulin, the results showed that in the presence of insulin and cycloheximide (upper panel Figure $42 \mathrm{~A}$ and white dots Figure $42 \mathrm{~B}$ ) there was a faster decrease of insulin receptor expression than that found in the group containing cycloheximide alone (upper panel Figure $42 \mathrm{~A}$ and black dots Figure $42 \mathrm{~B})$.

\subsubsection{Effect of proteasomal inhibitors on insulin receptor expression levels}

The previous result could be interpreted as an enhanced degradation of the insulin receptor. In order to determine whether the ligand-induced decrease of insulin receptor expression was due to proteasomal degradation, experiments including the proteasomal inhibitors lactacystin and MG132 were performed. The results of these experiments showed that a $24 \mathrm{~h}$ treatment with $5 \mu \mathrm{M}$ lactacystin did not prevent the downregulation of the receptor (Figure 43). Treatment for $24 \mathrm{~h}$ with a similar concentration of MG132 showed detrimental effects upon cell viability (Figure 43). Due to loss in cell viability caused by the MG132, the effect of this proteasomal inhibitor cannot be interpreted. 
(A)

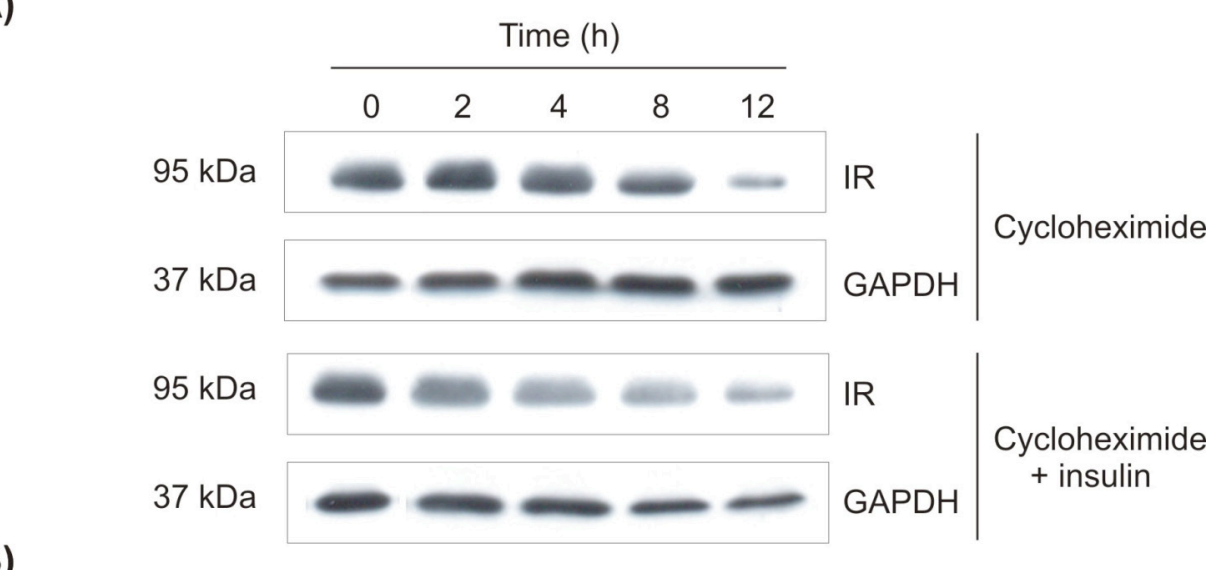

(B)

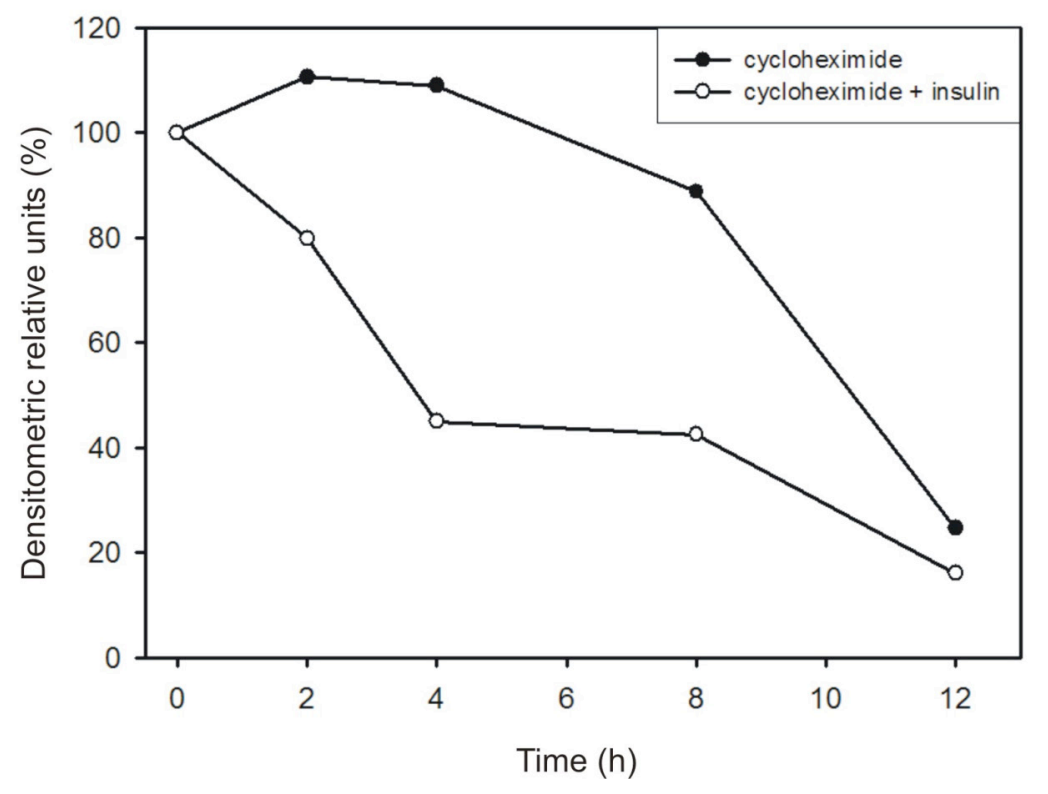

Figure 42. Effect of insulin treatment on insulin receptor expression in the presence of cycloheximide. IR expression was studied in the presence of the protein synthesis inhibitor cycloheximide. $24 \mathrm{~h}$ after plating the in medium containing serum, either $50 \mu \mathrm{g} / \mathrm{ml}$ cycloheximide alone or in combination with $100 \mathrm{nM}$ insulin were added to the cells (group $12 \mathrm{~h}$ ). The same protocol was followed with the rest of the groups at the indicated times. A) Representative immunoblot for IR. B) Densitometric analysis. Analysis was performed using the Biometra Bio Doc Analyze 2.0 program. Densitometric values were normalized to the untreated group (no insulin, no cycloheximide) (Fig. 42 B, first lane from the left). Insulin receptor values were also normalized to GAPDH. Densitometric values show the mean of two independent experiments. 
(A)

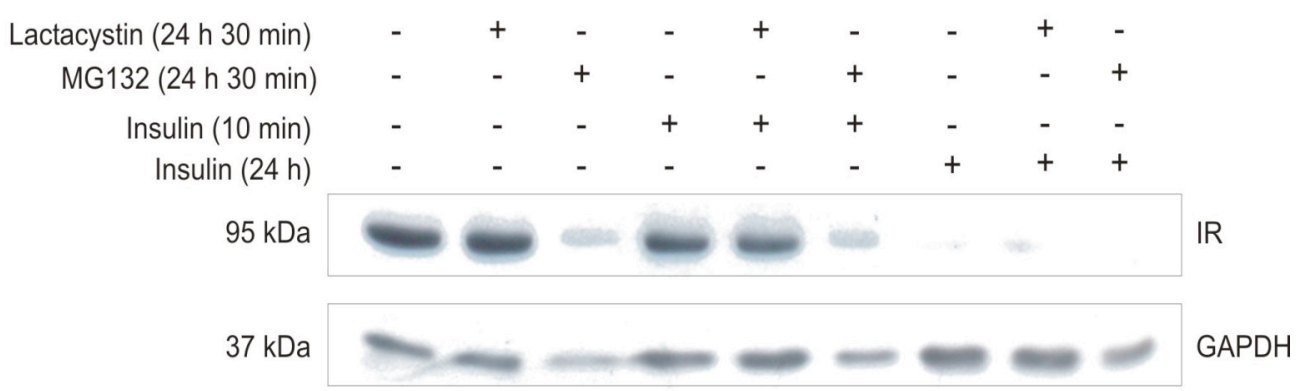

(B)

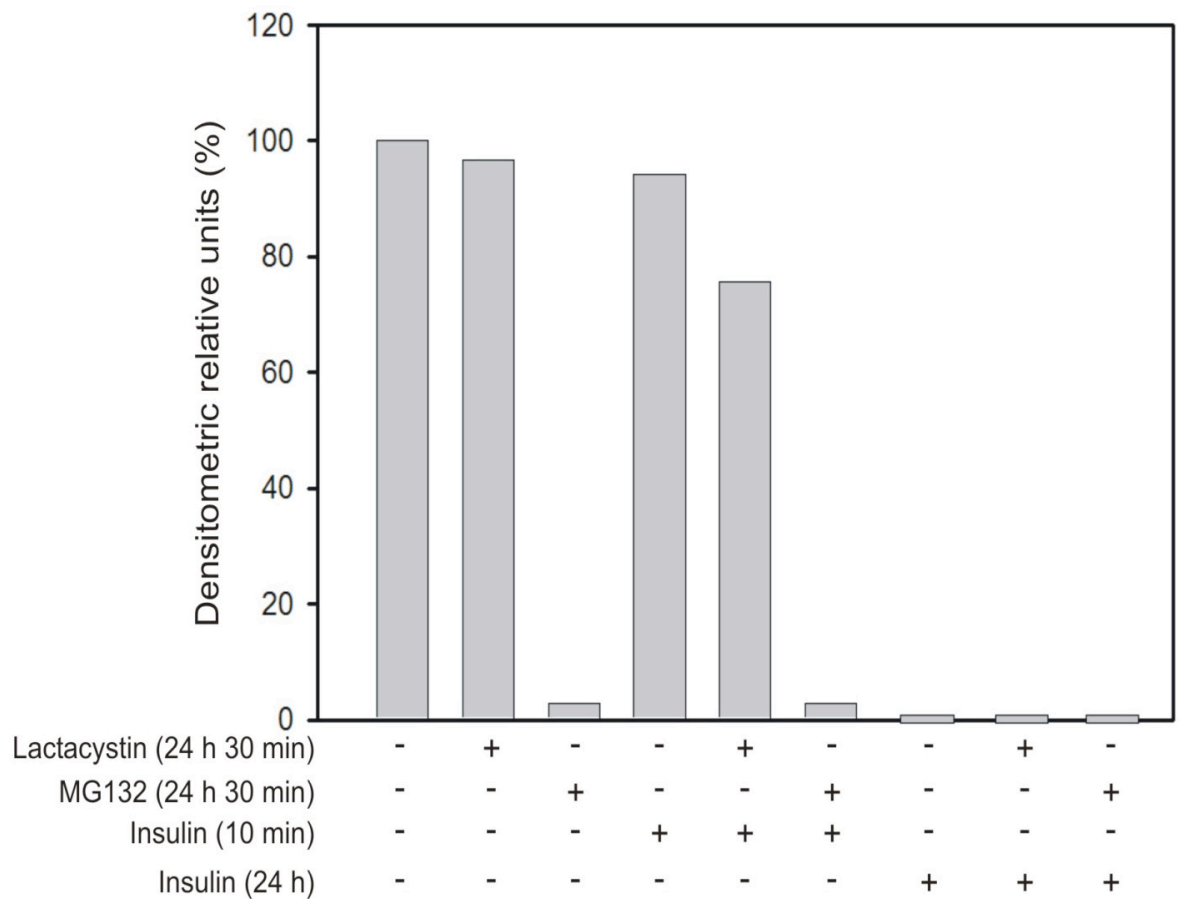

Figure 43. Effect of proteasomal inhibitors on insulin receptor expression levels. IR expression was studied in the presence of the specific proteasomal degradation inhibitors: lactacystin and MG132. $1.5 \mathrm{~h}$ after plating the cells in medium containing serum, $5 \mu \mathrm{M}$ lactacystin or $5 \mu \mathrm{M}$ MG132 were added to the cells. 30 min later, $100 \mathrm{nM}$ insulin was added to the cells. $24 \mathrm{~h}$ later, the $10 \mathrm{~min}$ insulin group received $100 \mathrm{nM}$ insulin. A) Representative immunoblot for the insulin receptor. B) Densitometric analysis. Analysis was performed using the Biometra Bio Doc Analyze 2.0 program. Densitometric values were normalized to the untreated group (no insulin, no lactacystin, no MG132) (Fig. 43 B, first lane from the left). Insulin receptor values were also normalized to GAPDH. Densitometric values show the mean of two independent experiments. 


\subsubsection{7 $\beta$-arrestin translocation}

Since the insulin-like growth factor receptor (IGF-1R) and the insulin receptor share structural and functional similarities, it is possible that the ligand-induced downregulation of the insulin receptor upon chronic insulin treatment could be caused by a degradation mechanism involving binding of $\beta$-arrestin to the insulin receptor (Dalle et al., 2001). In order to address this question, membrane translocation of $\beta$-arrestin in InR1G9 cells was studied after different insulin treatments (1, 10 or $30 \mathrm{~min}$ insulin treatment). Subcellular fractionation of insulin-treated InR1G9 cells followed by immunoblotting showed that InR1G9 cells expressed both arrestin isoforms: $\beta$-arrestin 1 and $\beta$-arrestin 2 . These isoforms were found in the cytoplasmatic fraction. In InR1G9 cells, the expression of $\beta$ arrestin 2 was higher than that of $\beta$-arrestin 1. A decreased signal for both $\beta$-arrestin forms was found in the membrane fraction in response to insulin (Figure 44). CCL5-stimulated rat basophilic leukemia cells (RBL) that stably express human chemokine receptor 5 (CCR5) were used as a positive control (Hüttenrauch et al., 2005) (Figure 44).

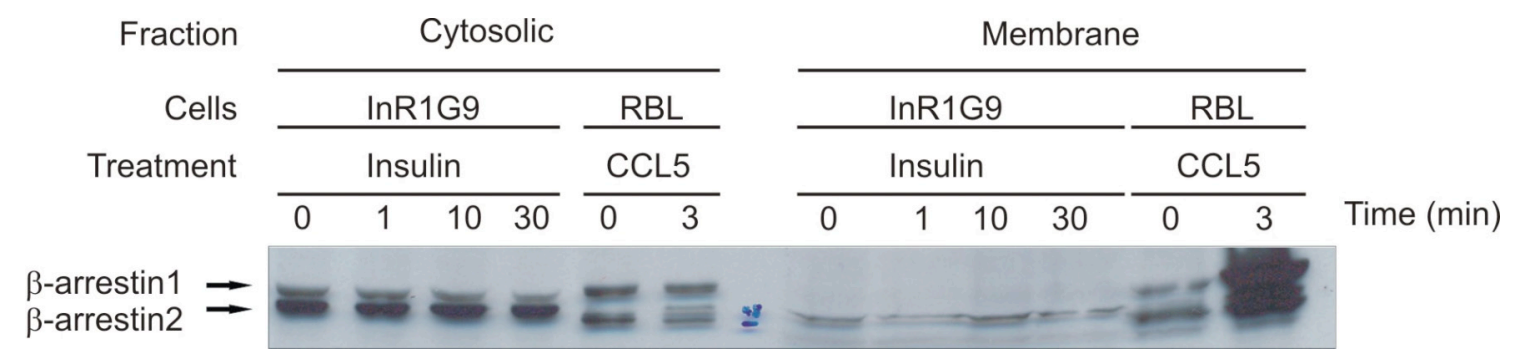

Figure 44. Effect of insulin treatment on $\beta$-arrestin expression and translocation from the cytoplasm to the cell membrane in InR1G9 cells. IR expression was studied after insulin treatment for different times (100 nM insulin for 1,10 or $30 \mathrm{~min}$ ). Cells were treated with insulin and were harvested after the indicated times. An ultracentrifugation-fractionation method was employed to separate the cytosolic and membrane fractions. These fractions were analyzed by immunoblotting for the two endogenous $\beta$-arrestin isoforms: $\beta$-arrestin 1 and $\beta$-arrestin 2 . The CCL5-induced translocation of both $\beta$-arrestin isoforms in BRL cells expressing the human chemokine receptor 5 (CCR5) was taken as a positive control. Representative immunoblot. 


\subsubsection{Effect of lysosomal inhibitors on insulin receptor expression levels}

Insulin receptor expression was studied in the presence of the lysosomal degradation inhibitors chloroquine and ammonium chloride (de Duve, 2005; Marshall and Olefsky, 1979; Wibo and Poole, 1974). The results of these experiments showed that upon a $25 \mathrm{~h}$ treatment with any of these substances and after a $24 \mathrm{~h}$ insulin treatment, no inhibition of insulin receptor degradation was observed (Figure 45). In the case of a $25 \mathrm{~h} 200 \mu \mathrm{M}$ chloroquine treatment, chloroquine exerted detrimental effects on the viability of InR1G9 cells (Figure 45). $9 \mathrm{~h}$ treatment with chloroquine reversed $22 \%$ of the inhibition achieved by treatment of the cells for $8 \mathrm{~h}$ with insulin (Figure 45). In the case of a $9 \mathrm{~h}$ treatment with $10 \mathrm{mM}$ ammonium chloride and a $8 \mathrm{~h}$ insulin treatment, ammonium chloride was not able to reverse the insulin-induced inhibition of insulin receptor expression (Figure 45). 


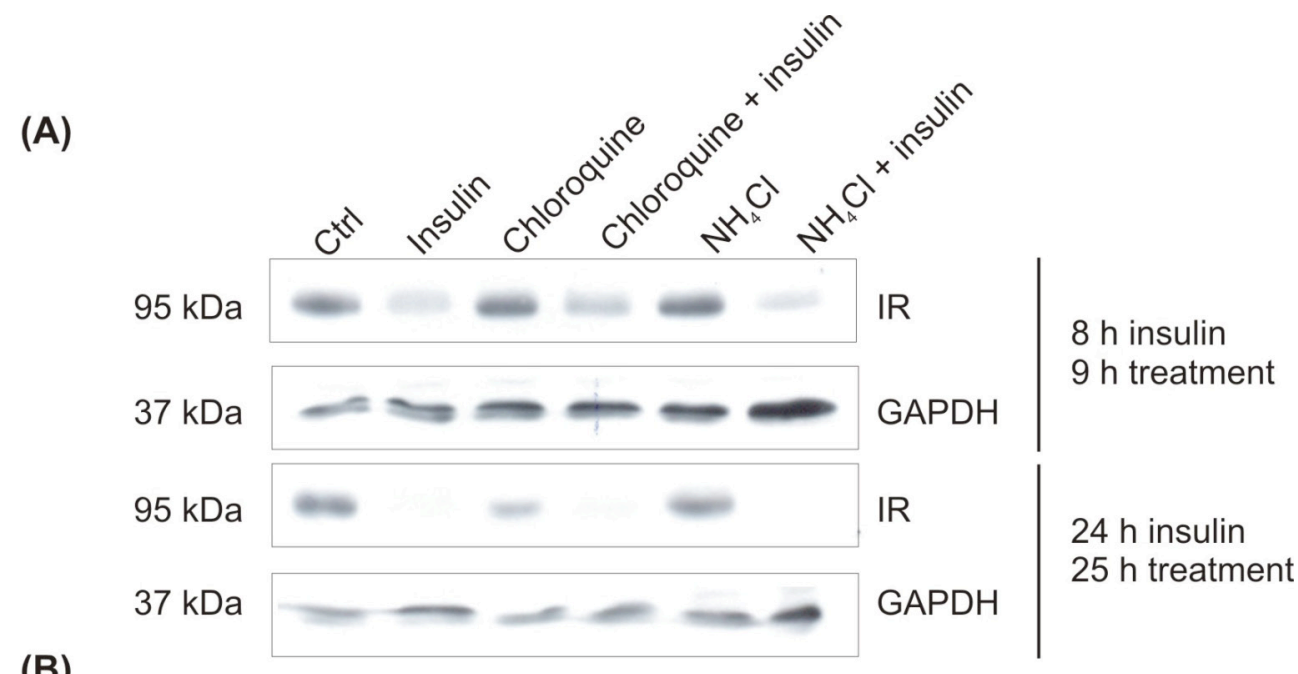

(B)

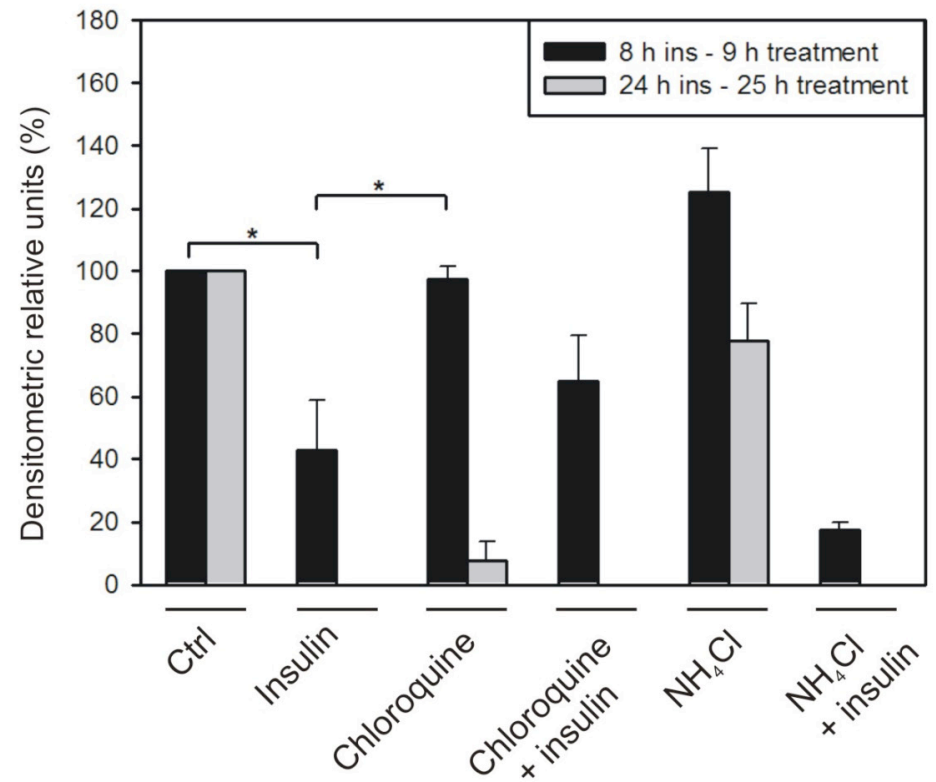

Figure 45. Effect of lysosomal inhibitors on insulin receptor expression levels. IR expression was studied in the presence of the lysosomal degradation inhibitors: chloroquine and ammonium chloride $\left(\mathrm{NH}_{4} \mathrm{Cl}\right) .1 \mathrm{~h}$ after plating the cells in medium containing serum, $200 \mu \mathrm{M}$ chloroquine or 10 $\mathrm{mM} \mathrm{NH}_{4} \mathrm{Cl}$ were added to the cells ( $25 \mathrm{~h}$ treatment group). $1 \mathrm{~h}$ later, $100 \mathrm{nM}$ insulin was added to the cells (24 h insulin group). $16 \mathrm{~h}$ later, $200 \mu \mathrm{M}$ chloroquine or $10 \mathrm{mM} \mathrm{NH}_{4} \mathrm{Cl}$ were added to the cells ( $9 \mathrm{~h}$ treatment group). $1 \mathrm{~h}$ later, the cells received $100 \mathrm{nM}$ insulin ( $8 \mathrm{~h}$ insulin group). A) Representative immunoblot for the insulin receptor. B) Densitometric analysis. Analysis was performed using the Biometra Bio Doc Analyze 2.0 program. Densitometric values were normalized to the untreated group (no insulin, no chloroquine, no ammonium chloride) (Fig. $45 \mathrm{~B}$, first lane from the left). Densitometric values show the mean $+/$ - SEM of three independent experiments. Statistical analysis was performed by paired Student t-test. ${ }^{*} \mathrm{p}<0.05$. 


\subsubsection{Expression and phosphorylation of the insulin receptor substrate 1}

Analysis of insulin receptor expression and phosphorylation upon chronic insulin treatment indicated that the defect in signaling was at the level of the insulin receptor. In order to determine whether the decrease in insulin receptor levels could affect immediate targets of insulin signaling, phosphorylation and expression of the insulin receptor substrate 1 were studied. Cell lysates of cells treated with $100 \mathrm{nM}$ insulin for either $23 \mathrm{~h} 10 \mathrm{~min}$, or for only 10 minutes, were analyzed by immunoblotting with antibodies against Tyr 612phosphorylated insulin receptor substrate 1 or against insulin receptor substrate 1 . While 10 min insulin treatment resulted in a strong phosphorylation, extended insulin exposure for 23 h 10 min decreased insulin receptor substrate 1 phosphorylation by $86.1 \%$ (upper blot and panel Figure $46 \mathrm{~A}$ and Figure $46 \mathrm{~B}$, respectively). In addition IRS-1 expression levels were increased 2.9-fold upon a 10 min insulin treatment and reduced upon $23 \mathrm{~h} 10$ min insulin treatment by $25.7 \%$ (lower blot and panel Figure $46 \mathrm{~A}$ and Figure $46 \mathrm{~B}$, respectively). 
(A)

(B)

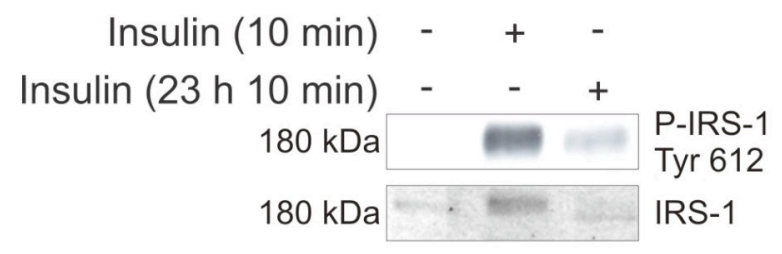

Insulin (10 min)

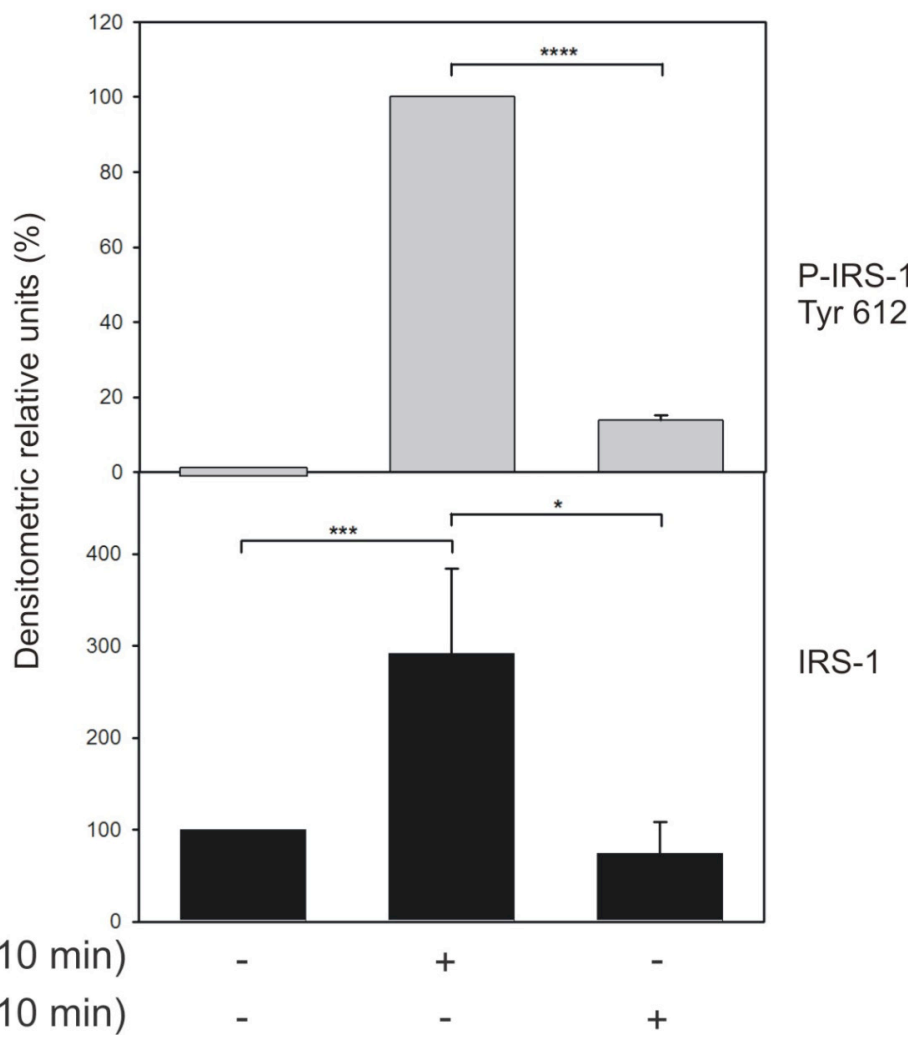

Figure 46. Effect of an extended insulin exposure on insulin receptor substrate 1 phosphorylation on Tyr 612 and expression. $2 \mathrm{~h}$ after plating the cells in medium containing serum, cells were treated with $100 \mathrm{nM}$ insulin ( $23 \mathrm{~h} 10 \mathrm{~min}$ insulin group). $23 \mathrm{~h}$ later, $100 \mathrm{nM}$ insulin was added to the cells (10 min insulin group). A) Representative immunoblot for phosphorylated insulin receptor substrate 1 on Tyr 612 and for the insulin receptor substrate 1. B) Densitometric analysis. Analysis was performed using the Biometra Bio Doc Analyze 2.0 program. Densitometric values were normalized to the 10 min insulin group (upper panel Fig. $40 \mathrm{~B}$, second lane from the left) and to the untreated group (lower panel Fig. $46 \mathrm{~B}$, first lane from the left). Densitometric values show the mean $+/$ - SEM of three independent experiments. Statistical analysis was performed by paired Student t-test. ${ }^{*} p<0.05 ;{ }^{* * *} p<0.005 ;{ }^{* * *} p<0.0000005$. 


\subsubsection{Interleukin 1-beta}

\subsubsection{Effect of interleukin 1-beta on PKB phosphorylation and expression}

The functional experiments showed that interleukin 1-beta (IL-1 $\beta$ ) inhibited basal glucagon gene transcription and at the same time it reversed the insulin-mediated inhibition of this gene. A study aimed to find the step at which $\mathrm{IL}-1 \beta$ interfered with insulin signaling was performed. The first candidate within the insulin signaling pathway analyzed was protein kinase B. Cell lysates of cells treated with either $10 \mathrm{nM}$ insulin for 10 minutes, with $10 \mathrm{ng} /$ $\mathrm{ml} \mathrm{IL-1} \beta$ for $1 \mathrm{~h} 10 \mathrm{~min}$, or with a combination of both substances were evaluated by immunoblot analysis. Insulin induced PKB phosphorylation, while upon IL-1 $\beta$ treatment no phosphorylation was found (Figure 47). Combination of both did not decrease PKB phosphorylation (upper blot and panel Figure $47 \mathrm{~A}$ and Figure $47 \mathrm{~B}$, respectively). PKB protein level was not modified after the different treatments (lower blot and panel Figure 47 A and Figure $47 \mathrm{~B}$, respectively).

\subsubsection{Effect of interleukin 1-beta on insulin receptor phosphorylation and expression}

The result shown in the previous section indicated that interleukin 1- $\beta$ might have acted downstream of PKB. In order to exclude interference by IL-1 $\beta$ with a target upstream of $\mathrm{PKB}$, the effect of $\mathrm{IL}-1 \beta$ at the level of the insulin receptor autophosphorylation was studied. Treatment for 1 h 10 min with IL-1 $\beta$ did not show insulin receptor phosphorylation on Tyr 1150 / 1151 (Figure 48). Combination of IL-1 $\beta$ and insulin did not produce a detectable change in the insulin-induced phosphorylation of the insulin receptor (upper blot and panel Figure $48 \mathrm{~A}$ and Figure $48 \mathrm{~B}$, respectively) or in insulin receptor expression levels (lower blot and panel Figure $48 \mathrm{~A}$ and Figure $48 \mathrm{~B}$, respectively). 
(A)

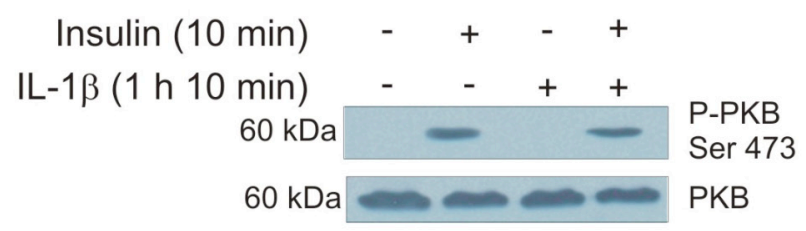

(B)

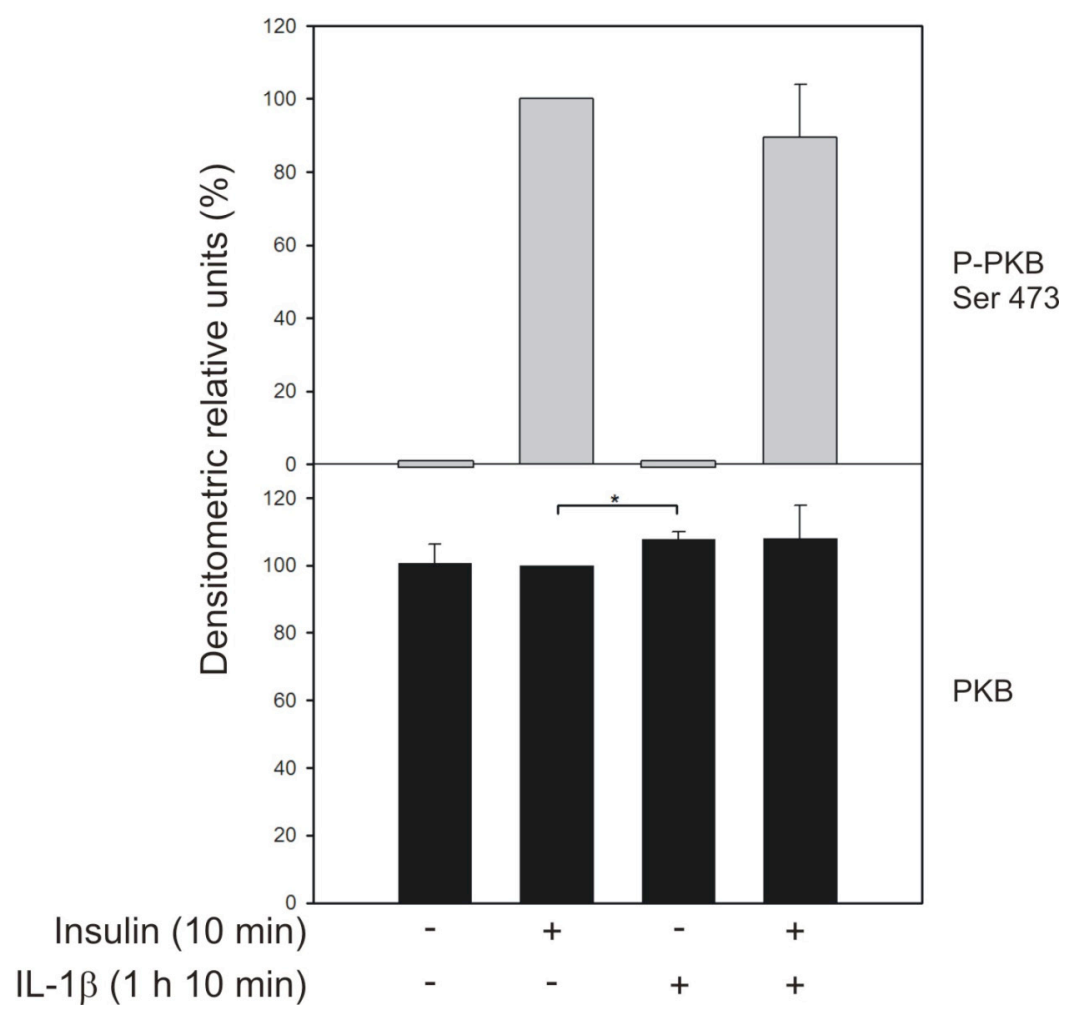

Figure 47. Effect of interleukin 1-beta treatment on PKB phosphorylation and expression. Cells were plated in medium containing serum. $24 \mathrm{~h}$ later, cells were washed and the medium was replaced with a medium containing $0.5 \%$ BSA. Immediately, $10 \mathrm{ng} / \mathrm{ml} \mathrm{IL-1 \beta}$ was added to the cells. $1 \mathrm{~h}$ later, cells in the $10 \mathrm{~min}$ insulin group were treated with $10 \mathrm{nM}$ insulin. A) Representative immunoblot for Ser 473-phosphorylated PKB and PKB after IL-1 $\beta$ and insulin treatments. B) Densitometric analysis. Analysis was performed using the Biometra Bio Doc Analyze 2.0 program. Densitometric values were normalized to the $10 \mathrm{~min}$ insulin group (upper panel Fig. $47 \mathrm{~A}$, second lane from the left) and to the untreated group (lower panel Fig. $47 \mathrm{~B}$, first lane from the left). Densitometric values show the mean $+/$ - SEM of three independent experiments. Statistical analysis was performed by paired Student t-test. ${ }^{*} p<0.05$. 
(A)

(B)
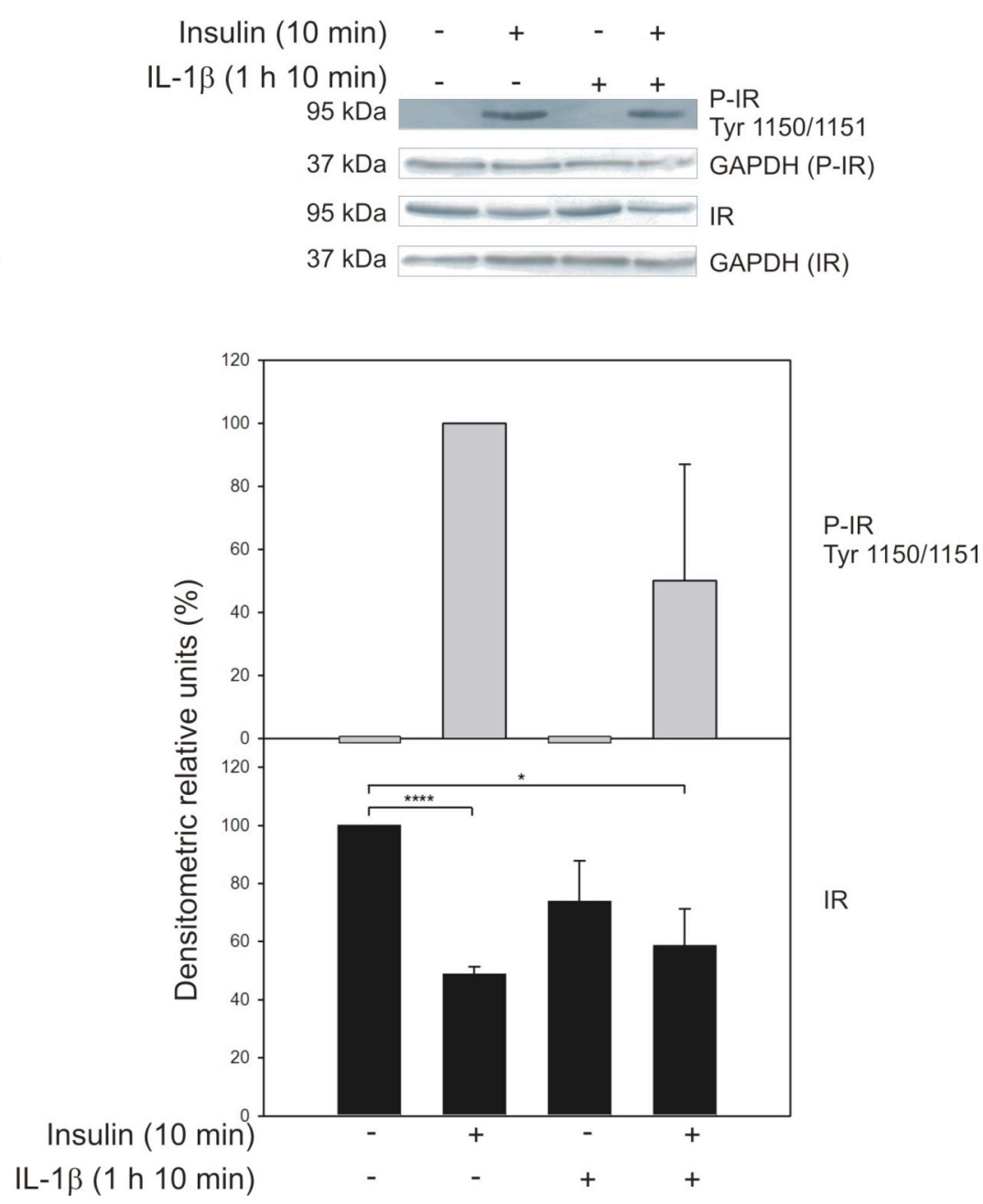

Figure 48. Effect of interleukin 1-beta treatment on insulin receptor phosphorylation and expression. $24 \mathrm{~h}$ after plating cells in medium containing serum, the medium was changed for a medium containing $0.5 \%$ BSA. Immediately. $10 \mathrm{ng} / \mathrm{ml} \mathrm{IL-1 \beta}$ was added to the cells. $1 \mathrm{~h}$ later, a 10 $\mathrm{nM}$ insulin treatment was performed for the next $10 \mathrm{~min}$. A) Representative immunoblot for phosphorylated insulin receptor on Tyr $1150 / 1151$ and for insulin receptor. B) Densitometric analysis. Analysis was performed using the Biometra Bio Doc Analyze 2.0 program. Densitometric values were normalized to the insulin group (upper panel Fig. $48 \mathrm{~B}$, second lane form the left) and to the untreated group (lower panel Fig. $48 \mathrm{~B}$, first lane from the left). Phosphorylated insulin receptor values as well as insulin receptor values were also normalized to GAPDH. Densitometric values show the mean +1 - SEM of four independent experiments. Statistical analysis was performed by paired Student t-test. ${ }^{* * * *} p<00005 ;{ }^{*} p<0.05$. 


\section{DISCUSSION}

The importance of understanding insulin action arises by the increasing prevalence of insulin resistance in various populations and by the fact that it plays an important role in the development of type II diabetes mellitus (Buren and Eriksson, 2005). One of the conveying points from researchers studying insulin resistance in different models is that insulin resistance is mainly caused by defects in insulin signaling such as impaired phosphorylation events (Buren and Eriksson, 2005; Zick, 2001). Furthermore, some molecules involved in the disruption of insulin signaling have been identified like tumor necrosis factor alpha or interleukin-6 (George et al., 2004; Usui et al., 2005; Zick, 2001; Zick, 2004). Studies on insulin resistance have focused mainly on insulin responsive organs like adipose tissue, skeletal muscle and liver (Anderwald and Roden, 2004; Carpentier et al., 1992; Karpe and Tan, 2005). There is no information about the induction of insulin resistance at the level of the pancreatic islet $\alpha$-cells. Considering that $\alpha$-cells are located at the periphery of the islets of Langerhans, these cells are exposed to high insulin concentrations released from the more centrally localized $\beta$-cells (Lefebvre, 1995; Unger, 1981; Unger and Orci, 1981). In the present study, different substances, involved in the induction of insulin resistance in other tissues, were tested in a pancreatic $\alpha$-cell line, in which insulin has been shown to inhibit glucagon secretion and glucagon gene transcription (Philippe, 1989). Two substances, insulin and interleukin 1-beta, decreased the insulin-induced inhibition of glucagon gene transcription in $\alpha$-cells. From the different substances studied, these two substances were the only ones that are secreted from $\beta$ cells (Maedler and Donath, 2004), underlining the importance of the paracrine mechanism occurring in the pancreatic islets. Further analysis was performed to detect their interference level within the insulin signaling pathway.

Insulin resistance is a metabolic disorder characterized by a diminished ability of insulin to maintain glucose homeostasis. This disorder is characterized by hyperglycemia, hyperinsulinemia and hyperglucagonemia (Howard, 1985). It has been shown that hyperglucagonemia is caused by an increase in the transcription of the glucagon gene (Grzeskowiak et al., 2000) and its secretion, processes normally controlled by insulin. Detailed studies of the glucagon promoter using the pancreatic islet $\alpha$-cell line InR1G9, have provided a coherent panorama of the regulation of glucagon gene transcription by insulin, including a proposal of the respective insulin signaling pathway (Grzeskowiak et 
al., 2000; Schinner et al., 2005a) (Figure 3). The present study took advantage of this model. The insulin-mediated inhibition of glucagon gene transcription was confirmed in the tumor cell line InR1G9 (Grzeskowiak et al., 2000; Schinner et al., 2005a). The substances, shown to confer insulin resistance in other study models and examined in the present study, can be grouped into substances with no effect, with novel effects or with known effects on glucagon gene transcription and substances with an insulin resistance-inducing effect (Tables 1 and 2).

\subsection{Substances without an effect on glucagon gene transcription}

The first group within the compounds tested includes those that produced no effect on glucagon gene transcription. This group contained the cytokine interleukin-6, the glucocorticoid dexamethasone and the immunosuppressants cyclosporin A and tacrolimus (Tables 1 and 2). Insulin resistance is related to an increase of inflammatory markers including interleukin-6 (Pickup et al., 2000; Rotter et al., 2003). The results from the present study showed that neither a short nor a long exposure of InR1G9 cells to interleukin-6 influenced basal glucagon gene transcription. Although only a few studies have addressed the potential metabolic effects of interleukin- 6 and / or its ability to modify insulin sensitivity and action, there are some evidences suggesting that interleukin-6 induces insulin resistance in in vitro systems such as myoblasts (Tzeng et al., 2005), adipocytes (Rotter et al., 2003) and hepatocytes (Senn et al., 2002). Therefore, after treatment of InR1G9 cells with interleukin-6, an insulin resistance-inducing effect was expected, i.e. a reversal of the insulin-induced inhibition of glucagon gene transcription. The concentrations used in this thesis did not present this insulin resistance-inducing effect, although these concentrations have been reported as active concentrations for the induction of insulin resistance in other study models. The mechanisms by which interleukin- 6 induces insulin resistance are complicated and are far from being understood (Kumar and O'Rahily, 2005).

The second member of this group was dexamethasone. Dexamethasone, a synthetic member of the glucocorticoid class of hormones, possesses a high binding affinity to the glucocorticoid receptor. Glucocorticoids impair insulin sensitivity and inhibit insulin secretion from pancreatic $\beta$-cells (Lambillotte et al., 1997). In primary cultured adipocytes, dexamethasone induced different mechanisms of insulin resistance after acute or chronic exposure to this hormone (Garvey et al., 1989). In the present study, the effect of 
dexamethasone at different exposure times was also investigated. However, none of the treatments with dexamethasone showed a relevant effect on glucagon gene transcription. Contrary to a rightward shift in the insulin dose-response curve caused by dexamethasone in adipocyte experiments (Garvey et al., 1989) a slight, if anything, left-ward shift, which means rather sensitization of the cells to insulin, was observed in the present work. As reported by Wang et al. (1991), dexamethasone does not causes an effect on glucagon gene transcription due to an unaltered concentration of glucagon mRNA transcripts, observed after different dexamethasone treatments (Wang et al., 1991).

The third and fourth members of this group are cyclosporin A and tacrolimus. Cyclosporin $A$ and tacrolimus are immunosuppressants, which through binding to their respective intracellular receptors lead to the inhibition of calcineurin. Calcineurin blockage inhibits the CRE / CREB-mediated gene transcription of genes such as the insulin (Oetjen et al., 2003a; Oetjen et al., 2003b) and glucagon genes (Fürstenau et al., 1999). Treatment with these drugs for the immunosuppression of patients undergoing organ transplantation has led to prolonged life expectancy. However, after a long-term treatment with these drugs alterations in glucose and lipid metabolism can take place. Alterations in glucose metabolism impair glucose tolerance leading to hyperglycemia and diabetes mellitus. Posttransplant diabetes can be found in patients treated with tacrolimus due to its marked effects on $\beta$-cells (Marchetti and Navalesi, 2000; Weir, 2001). Experiments with either cyclosporin A or with tacrolimus did not induce an insulin resistant state at the glucagon gene in the current study. Basal glucagon gene transcription was also not affected by these substances in a relevant way, consistent with results obtained by Schwaninger et al. (Schwaninger et al., 1995). Nevertheless, it can be suggested that cyclosporin A and tacrolimus can induce insulin resistance by other mechanisms.

\subsection{Substances with novel effects on glucagon gene transcription}

This group encloses substances that are known to induce insulin resistance in other systems but that did not prevent the inhibition by insulin of glucagon gene transcription; they nevertheless led to novel effects in this model. Among these substances are: hydrogen peroxide $\left(\mathrm{H}_{2} \mathrm{O}_{2}\right)$, free fatty acids (FFA) and TNF $\alpha$. The first member of the group was hydrogen peroxide. In insulin resistant states lipid peroxidation is increased, leading to generation of reactive oxygen species (ROS) (Evans et al., 2002; Evans et al., 2005). However, the mechanistic link between ROS and insulin resistance is not well known. In 
previous years, hydrogen peroxide was considered as a toxic by-product of metabolism; however, nowadays it is also recognized as a signaling molecule involved in the regulation of cellular function. An increased production of hydrogen peroxide or a reduced capacity of its elimination can lead to abnormal changes in intracellular signaling and result in insulin resistance (Evans et al., 2002; Evans et al., 2005). In the current study it was shown that different hydrogen peroxide concentrations inhibited basal glucagon gene transcription but did not interfere with the insulin-induced inhibition of glucagon gene transcription. These results do not correspond to the previous concept for oxidative stress and insulin resistance. However, recently oxidative enhancement of insulin receptor signaling has been described (Droge, 2005). In that study insulin receptor kinase autophosphorylation and / or kinase activity was markedly enhanced by a limited exposure to hydrogen peroxide. The author postulates that this effect might be mediated through direct oxidative activation of insulin receptor kinases or by oxidative inactivation of protein tyrosine phosphatases, which otherwise downregulate insulin receptor kinase-mediated signaling (Droge, 2005). From the results in the present work it can be suggested that hydrogen peroxide does not exert the induction of an insulin resistant state in InR1G9 cells.

In the second place of substances with a novel effect are free fatty acids (FFA). FFA provide an important energy source as nutrients, and they act as signaling molecules in various cellular processes, including insulin secretion (Haber et al., 2003; Nunez, 1997). Nevertheless, increased concentrations of FFA can lead to impaired insulin signaling (Griffin et al., 1999) thus promoting the development of insulin resistance. Insulin resistance of skeletal muscle of humans and animals is often strongly correlated with increased lipid availability. The elevation of certain intracellular lipid species can lead to the activation of signal transduction pathways that inhibit insulin action (Schmitz-Peiffer, 2002). Elevation of FFA increases the concentration of diacylglycerol in muscle, activating one or more isoforms of protein kinase C (PKC) (Dey et al., 2006; Dey et al., 2005; Griffin et al., 1999). Augmented PKC impairs insulin signaling (Dey et al., 2006; Dey et al., 2005; Griffin et al., 1999) in most of the cases at the level of the insulin receptor substrate 1 (IRS-1). This alteration in signaling seems to be mediated by different mechanisms, one of them being an increase in phosphorylation of IRS-1 on serine / threonine residues instead of tyrosine residues (Schmitz-Peiffer, 2002; Shulman, 2000). In this study, FFA exerted a wide variety of responses depending on the degree of saturation of the fatty acid used. One of the FFA investigated was the unsaturated or non-esterified palmitic acid (palmitate). Treatment of InR1G9 cells with palmitate did not modify basal glucagon gene 
transcription or the insulin-induced inhibition of glucagon gene transcription. Plasma nonesterified FFA exert a wide variety of tissue-specific effects. Non-esterified FFA promote hepatic glucose overproduction (Rebrin et al., 1995), inhibit pancreatic $\beta$-cell function and insulin secretion (Shimabukuro et al., 1998), impair glucose utilization by the glucose fatty acid cycle (Randle et al., 1963; Randle et al., 1994) and elevate ceramide levels by de novo synthesis (Schmitz-Peiffer et al., 1999). In adipocytes palmitate inhibits insulininduced glucose transport (Van Epps-Fung et al., 1997). Thus, the results of the present work are not in agreement with the insulin resistance-inducing effect of palmitate in skeletal muscle cells or in adipocytes (Storz et al., 1999). The palmitate concentration used in this thesis was comparable to concentrations used in previous studies; thus excluding the possibility that the lack of palmitate effect could be caused by an insufficient palmitate concentration (Van Epps-Fung et al., 1997). Since no effects were observed with this saturated FFA, the possibility that a longer saturated FFA could have an effect on this model was considered. Therefore, the effect of stearic acid (stereate) was investigated. Stearic acid is known to promote inhibition of insulin-stimulated glycogen synthesis, inhibition of PKB and accumulation of ceramide; processes that cause insulin resistance (Chavez and Summers, 2003). The results of the present study showed that the length of the saturated FFA was not the reason for a lack of an effect on the insulin-induced inhibition of glucagon gene transcription. Nevertheless, upon stearic acid treatment a 1.5fold activation on basal glucagon gene transcription was observed. It can be suggested that the activation of basal glucagon gene transcription by stearic acid and not by palmitic acid can be due to differences in metabolic processing of these two saturated fatty acids (Bruce and Salter, 1996). Thus it was concluded that saturated FFA were not inducing an insulin resistance effect in this model. Therefore the effect of different unsaturated FFA was investigated. The results of experiments with the unsaturated fatty acids: oleic (oleate), linoleic (linoleate) and linolenic (linolenate) acids showed no major effects on the insulin-induced inhibition of glucagon gene transcription. However, a marked inhibition of basal glucagon gene transcription was found. Interestingly, the inhibition of basal glucagon gene transcription was directly proportional to the saturation degree of the FFA investigated. The variation of effects does not only seem to be saturation-dependent but also tissue-specific (Lundgren and Eriksson, 2004; Ohashi et al., 2004; Qiu et al., 2005; Randle et al., 1963). From the results of the present work, it can be speculated that the time to which InR1G9 cells were exposed to unsaturated FFA was not sufficient to cause an insulin resistant state in $\alpha$-cells. 
TNF $\alpha$ is a potent multifunctional hormone with a wide range of biological activities (Kumar and O'Rahily, 2005; MacEwan, 2002). TNF $\alpha$ presents cytotoxic activity in a wide variety of cells and promotes immunity, inflammation, hypotension, septic shock, apoptosis and during recent years it has been shown as a candidate promoting insulin resistance. Although extensive research in different tissues has been performed in order to understand how $\mathrm{TNF}_{\alpha}$ induces insulin resistance, the exact mechanism remains unclear (Hotamisligil, 1999). In the present work, treatment of InR1G9 cells with TNF $\alpha$ for 24 or 46 h modified neither basal glucagon gene transcription nor insulin-mediated transcription of this gene. The results from this study do not suggest an insulin resistance-inducing effect by TNF $\alpha$ in $\alpha$-cells. This was independent from the duration of the treatment or from the TNF $\alpha$ doses used. These results do not correlate with in vitro experiments in other study models, in which similar concentrations of TNF $\alpha$ interfered with insulin action (Hotamisligil et al., 1994; Qi and Pekala, 2000). In addition, in in vivo models of type II diabetes mellitus, TNF $\alpha$ mediated abnormalities in glucose homeostasis and therefore induced insulin resistance. It has been proposed that TNF $\alpha$ induces insulin resistance since it directly interferes with insulin signaling (Hotamisligil et al., 1994). However, other in vitro studies using rat soleus muscle have found no influence of TNF $\alpha$ over insulin-stimulated glucose transport, glycogen synthesis, glycolysis and glycogen accumulation, processes correlated with insulin resistance (Fürnsinn et al., 1997). The first TNF $\alpha$ concentrations used in the present study were within the range of the dissociation constants for the TNF $\alpha$ binding to TNF receptors (Grell et al., 1998); excluding the possibility that the lack of TNF $\alpha$ effect in this study could be due to insufficient TNF $\alpha$ doses. Nevertheless, a $24 \mathrm{~h}$ treatment with an elevated TNF $\alpha$ concentration (a concentration which exceeds 10-fold the dissociation constants for TNF binding to TNF receptors) (Grell et al., 1998) inhibited $30 \%$ of basal glucagon gene transcription. This TNF $\alpha$-mediated inhibition was further studied in the presence of different stimuli of glucagon gene transcription. It has been previously shown that the glucagon promoter is activated by cAMP and membrane depolarization (Knepel et al., 1990; Schwaninger et al., 1993), as well as by protein kinase C (Philippe et al., 1987) or protein kinase A (Knepel et al., 1990). In the current study, TNF $\alpha$ was able to inhibit the stimulation of glucagon gene transcription caused by stimuli acting through different pathways: membrane depolarization, activation of protein kinase $C$ (PKC) and activation of adenylate cyclase, followed by activation of protein kinase $A$ (PKA). The results suggested that the TNF $\alpha$-induced inhibition of glucagon gene transcription was independent of any of the glucagon transcription activation pathways studied. Considering that elevated levels of 
TNF $\alpha$ are linked to the development of septic shock (Darling et al., 1989) and that during septic shock a disordered metabolite handling can occur, it can be suggested that the TNF $\alpha$-induced inhibition of glucagon gene transcription may be involved in sepsis-induced hypoglycemia.

\subsection{Substances with known effects on glucagon gene transcription}

The members of this group were the cell permeable cAMP analog 8BrcAMP and the peroxisome proliferator-activated receptor gamma (PPAR $\gamma$ ). They did not prevent the inhibition by insulin of glucagon gene transcription, but produced known effects on glucagon gene transcription.

Treatment of InR1G9 cells with 8BrcAMP showed no effect on the insulin-induced inhibition of glucagon gene transcription. However, 8BrcAMP significantly activated basal glucagon gene transcription. This was considered as a known effect since 8BrcAMP activates cAMP-dependent protein kinase $A$, that induces the expression of genes containing a cis-acting DNA sequence, called cAMP-response element (CRE) by phosphorylating CRE-binding protein (CREB). Phosphorylated CREB then transactivates the transcription of target genes (Lodish et al., 2000) like the glucagon gene (Fürstenau et al., 1999; Schwaninger et al., 1993).

The second member in this group was an expression vector for the peroxisome proliferator-activated receptor gamma (PPAR $\gamma$ ). PPAR $\gamma$ belongs to the family of peroxisome proliferator-activated receptors (PPARs), which are transcription factors that regulate the expression of specific genes especially in fat cells but also in other tissues. The mechanism of action of PPARs is through transduction of metabolic and nutritional signals into transcriptional responses (Bernal-Mizrachi et al., 2003). PPAR $\gamma$ binds to its specific promoter response elements as a heterodimer with the retinoid $X$ receptor $(R X R)$. In the presence of a ligand, the dimerized complex recruits coactivator molecules, which lead to the initiation of transcription. However, PPAR $\gamma$ may influence gene expression indirectly, and usually negatively through competition with other transcription factors for such accessory molecules. In the present work, PPAR $\gamma$ inhibited $30 \%$ of basal glucagon gene transcription in InR1G9 cells. In combination with insulin it did not influence the insulin-induced inhibition of glucagon gene transcription. This result is in agreement with 
studies showing that nuclear receptors such as PPAR $\gamma$ are involved in insulin resistance (Rangwala and Lazar, 2004) and with the results found by Schinner et al. (2002), suggesting that PPAR $\gamma$ inhibited glucagon gene transcription through inhibition of transactivation by the transcription factor Pax6 (Schinner et al., 2002). PPAR ligands are "insulin sensitizers"; in the present study no sensitization by PPAR $\gamma$ was found. The identification of fatty acids as endogenous ligands for PPARs has provided a unique approach to study lipid homeostasis at the molecular level (Forman et al., 1997; Forman et al., 1995; Kliewer et al., 1995; Kliewer et al., 1997; Krey et al., 1997). Thus the role of FFA in the presence or absence of PPAR $\gamma$ was investigated in the present work. In contrast to palmitic acid and stearic acid, the unsaturated fatty acids oleic acid, linoleic acid and linolenic acid exerted an inhibitory effect on glucagon gene transcription. The FFA did not exert an effect on insulin-induced inhibition of glucagon gene transcription. It has been shown that different saturation degrees of free fatty acids can bind to PPAR $\gamma$ with different affinities (Kliewer et al., 1997). In order to investigate whether the effects of PPAR $\gamma$ were ligand-selective, further experiments using the synthetic PPAR $\gamma$ ligand rosiglitazone, a thiazolidinedione (TZD), were performed. TZD provide clinically effective glycemic control and improve insulin sensitivity (Vasudevan and Balasubramanyam, 2004) through interference with expression and release of mediators of insulin resistance originated in the adipose tissue (i.e. FFA, adipokines such as TNF $\alpha$, resistin, adiponectin) (Stumvoll and Haring, 2002). In the presence of insulin, like PPAR $\gamma$ alone, also the receptor-ligand complex did not change the insulin-induced inhibition of glucagon gene transcription. In vivo, this kind of synthetic ligands for PPAR (Lehmann et al., 1995), work by lowering blood glucose and by improving lipid profiles in animal models of diabetes and in patients with type II diabetes mellitus (Day, 1999). Therefore TZD play a role in insulin resistant states by increasing insulin sensitivity (Rangwala and Lazar, 2004). An insulin sensitizing effect by PPAR $\gamma$ and thiazolidinediones was not observed in vitro in the present study. Furthermore, it should be noted that in vivo the effect of TZD requires a chronic treatment of several weeks to appear.

\subsection{Substances that interfered with the insulin-induced inhibition of glucagon gene transcription}

Elevated levels of certain cytokines produced by adipose tissue or by $\beta$-cells, including interleukin 1-beta (IL-1 $\beta$ ) and elevated levels of insulin are present in insulin resistant 
states (Maedler et al., 2004). Therefore, it was of interest to study whether elevated levels of these substances could induce an insulin resistant state in $\alpha$-cells. The results from the current work showed that indeed, these substances reversed the insulin-induced inhibition of glucagon gene transcription, therefore inducing an insulin resistant state.

\subsubsection{Interleukin 1-beta}

Interleukin 1-beta (IL-1 $\beta$ ) is a proinflammatory cytokine involved in the development of type I and type II diabetes mellitus (Emanuelli et al., 2004; Nerup et al., 1994) mostly by regulating insulin secretion. It has been suggested that IL-1 $\beta$ causes $\beta$-cell apoptosis, impairing $\beta$-cell survival and function (Maedler et al., 2004). This decreased $\beta$-cell function is the cause for diabetes mellitus (Argiles et al., 1992). In addition, it has been recently proposed that high-glucose induced $\beta$-cell apoptosis in type II diabetes mellitus shares a final common pathway with type I diabetes mellitus, involving IL-1 $\beta$ production by $\beta$-cells, nuclear factor-kappaB activation and death via the death receptor / ligand Fas-FasL (Welsh et al., 2005). In the present study, IL-1 $\beta$ inhibited basal glucagon gene transcription and blocked the inhibition of glucagon gene transcription by insulin. Even when the information related to IL-1 $\beta$ is scarce, it has been found that this cytokine produces a tissue-specific insulin resistance-inducing effect (Emanuelli et al., 2004; GrzelkowskaKowalczyk and Wieteska-Skrzeczynska, 2006). In the current work, the insulin resistanceinducing effect caused by IL-1 $\beta$ was further analyzed by studying the step within the insulin signaling pathway to the glucagon gene at which this cytokine interfered with insulin action. The fact that insulin was not inhibiting glucagon gene transcription in the presence of IL-1 $\beta$ could be interpreted as an insulin resistance-inducing state at the level of the $\alpha$ cell. This could be the result of IL-1 $\beta$ interfering with insulin signaling. In order to find whether IL-1 $\beta$ interfered with insulin signaling, expression and phosphorylation of PKB were studied after IL-1 $\beta$ treatment. The results indicated that IL-1 $\beta$ treatment did not modify PKB protein expression or its Ser 473 phosphorylation. This result suggests that IL$1 \beta$ may act downstream of PKB. Nevertheless, in order to exclude interference upstream of PKB, the effect of IL-1 $\beta$ at the level of activity and expression of the insulin receptor was studied. A short treatment with insulin induced insulin receptor phosphorylation on Tyr 1150 / 1151 (see below), while a treatment with IL-1 $\beta$ did not show such an effect. Furthermore, IL-1 $\beta$ did not alter significantly the insulin-induced autophosphorylation of the insulin receptor and the insulin receptor expression levels. The results obtained in the 
present work, are in part in agreement with those obtained using a rat insulinoma beta cell line (Emanuelli et al., 2004). It can be concluded that IL-1 $\beta$ might interfere with a signaling target which is located downstream of PKB. The insulin resistance-inducing effect shown by IL-1 $\beta$ might be mediated through mechanisms that may involve the generation of nitric oxide species (Reimers et al., 1994), expression of the inducible nitric oxide synthase (iNOS) (Ishikawa and Morris, 2006) or high expression of the p38 mitogen-activated protein kinase (MAPK) (Fujishiro et al., 2001). Furthermore IL-1 $\beta$ markedly inhibited basal glucagon gene transcription through an unknown mechanism. This is one of the reasons to suggest that IL-1 $\beta$ may be less likely involved in the development of insulin resistance at the level of the $\alpha$-cells, since IL-1 $\beta$ produces a marked inhibition of basal glucagon gene transcription whereas type II diabetes mellitus is characterized by hyperglucagonemia. In addition, the lack of inhibition of glucagon gene transcription in the presence of IL-1 $\beta$ may be secondary to the marked inhibition by IL-1 $\beta$ of glucagon gene transcription.

\subsubsection{Insulin}

Levels of circulating insulin are chronically elevated in insulin resistant states (hyperinsulinemia). Therefore, it was important to find whether increased insulin levels or extended insulin exposures could impair the insulin-induced inhibition of glucagon gene transcription in $\alpha$-cells. Extending the treatment with insulin from $23 \mathrm{~h}$ to $46 \mathrm{~h}$ reversed the insulin-induced inhibition of glucagon gene transcription. Furthermore, functional experiments in the presence of a constitutively active form of PKB, demonstrated that after a chronic insulin treatment, PKB was still able to inhibit glucagon gene transcription. This result suggested that chronic insulin treatment could be impairing insulin signaling at the level of PKB or upstream of this protein kinase. PKB is considered a key regulator of insulin signaling to the glucagon gene (Schinner et al., 2005a). Impairment of PKB function by PKB inhibitors or by external signals leads to insulin resistance and diabetes mellitus (Koo et al., 2004; Krook et al., 1998; Zdychova and Komers, 2005). In order to address if in the current study this kinase was directly or indirectly involved in the desensitization caused by a chronic insulin treatment, the level of PKB protein and its Ser 473 phosphorylation were analyzed. After chronic insulin treatment, PKB phosphorylation was reduced while PKB expression remained unchanged, indicating that the desensitization effect was localized upstream of PKB in the insulin signaling pathway. These results are 
consistent with results obtained from experiments with human myoblasts (Bertacca et al., 2005).

Considering existing evidence of insulin desensitization during hyperinsulinemic states in other tissues (Heaton and Gelehrter, 1981), it was suggested that after a chronic insulin treatment, the activity and expression of the insulin receptor could be impaired also in $\alpha$ cells. The expression and functionality of the insulin receptor in $\alpha$-cells has been previously demonstrated (Kisanuki et al., 1995). Therefore, the activity and expression of the $\beta$-subunit of the insulin receptor were studied in $\alpha$-cells. The level of insulin receptor expression and its phosphorylation were determined by immunoblotting with anti-IR- $\beta$ and anti-Tyr 1150 / 1151 IR- $\beta$ antibodies, respectively. In the present study, a decreased insulin receptor expression was found upon chronic insulin treatment. In addition, a reduced insulin receptor phosphorylation on tyrosine residues $1150 / 1151$ was detected. Tyrosines 1150 and 1151 are two of the three tyrosines within the tyrosine kinase domain of the receptor that are required for insulin receptor autophosphorylation, an important event for the transduction of the insulin signal (Hubbard, 1997; Rosen et al., 1983). These results suggested that the decline in phosphorylation could be caused by a diminished insulin receptor expression. Considering that under physiological conditions, the amount of receptor decreases because of insulin binding and internalization, followed by a restoration by the addition of newly synthesized insulin receptors and that during pathological hyperinsulinemia, the internalization / recycling cycles constantly decrease the number of insulin receptors at the surface, a downregulation of the insulin receptor could be attributed as a cause of the insulin desensitization effect (Capeau, 2003; Treadway et al., 1989). Even when extensive information exists related to desensitization of insulin after a chronic insulin treatment (Blackard et al., 1978; Livingston et al., 1978a; Livingston et al., 1978b; Mott et al., 1979; Yuan et al., 2002), this is the first study in which the effects of chronic insulin treatment are addressed at the level of the pancreatic $\alpha$-cell.

In order to study insulin receptor autophosphorylation and thus kinase activity at earlier time points, a kinetic analysis of both insulin receptor activity and expression was performed. Serum-starved InR1G9 cells were incubated with or without insulin for variable times, and then analyzed by immunoblotting as previously described. Starting $2 \mathrm{~h}$ after insulin treatment, a time-dependent disappearance of the insulin receptor was found. The downregulation achieved its maximum after $24 \mathrm{~h}$ of insulin treatment $(90 \%$ decrease of the insulin receptor). A similar decrease was observed for the autophosphorylation of the 
insulin receptor. From these data, it can be suggested that the reduction in the phosphorylation of the insulin receptor was caused by the decrease in insulin receptor expression. In terms of the time scale at which the downregulation occurred, the results from the present work are in agreement with in vitro studies in cells derived from other tissues like 3T3-C2 fibroblasts (Treadway et al., 1989), murine fibroblasts (Knutson, 1991; Knutson et al., 1983) and 3T3-L1 adipocytes (Ronnett et al., 1982).

Having shown that a diminished activity of the insulin receptor was caused by a reduction in the number of receptors, it was of interest to study whether this process was reversible. The results indicated that this downregulation was reversible after insulin withdrawal. Recovery started after $6 \mathrm{~h}$ of insulin removal and was maximal at $24 \mathrm{~h}$. This result also corresponds to in vitro recovery experiments in hepatoma cells (Heaton and Gelehrter, 1981), in 3T3-L1 adipocytes (Ronnett et al., 1982), in 3T3-C2 fibroblasts (Knutson et al., 1983) and in human monocytes (Whitson and Kaplan, 1985). In addition, recovery of insulin action was not only confirmed at the level of expression of the insulin receptor but also at the level of transcription of the glucagon gene.

To investigate whether this reversible downregulation of the receptor was caused by an enhanced degradation of the insulin receptor, experiments in the presence of the protein synthesis inhibitor cycloheximide were performed. Insulin induced a decrease in insulin receptor expression levels also in the presence of cycloheximide. Since cycloheximide was not able to reverse the insulin-induced downregulation, this result suggested that indeed an enhanced degradation of the receptor is involved in the downregulation process. Similar effects have been observed in primary cultured adipocytes. In that model cycloheximide had no effect on the loss of maximal insulin responsiveness and insulin sensitivity or recovery. Therefore it was concluded that de novo insulin receptor synthesis was not involved in the development of insulin resistance (Traxinger and Marshall, 1989).

The protein amounts of the different signaling molecules involved in insulin action are regulated by their rates of synthesis and degradation (Rome et al., 2004). The results from the experiments with cycloheximide indicated that the insulin receptor downregulation after a chronic insulin treatment might have been mediated through an enhanced degradation process. The first pathway of degradation analyzed was the ubiquitin-proteasome system pathway, which is the major pathway of selective protein degradation in eukaryotic cells (Glickman and Ciechanover, 2002; Rome et al., 2004). In order to depict whether 
degradation was responsible for the decrease in insulin receptor expression, cells were treated with high insulin concentrations in the presence of the proteasomal inhibitors MG132 and lactacystin. MG132 (carbobenzoxy-L-leucyl-L-leucyl-L-leucinal) is a specific proteasome inhibitor whose target is the chymotrypsin like activity of the proteasome (Figueiredo-Pereira et al., 1994; Jensen et al., 1995). This inhibitor has been used mainly for the study of proteasomal degradation of insulin receptor substrate proteins (IRS). There is limited information describing the MG132-mediated inhibition of proteasomal degradation of the insulin receptor (Rondinone and Kramer, 2002). In the current study, even when the concentrations of MG132 used were within the range of those described for other systems, a detrimental effect on cell viability was found. Therefore conclusions cannot be made from the results obtained using this proteasomal inhibitor. Lactacystin is a microbial natural product that inhibits cell cycle progression and induces differentiation in a murine neuroblastoma cell line (Fenteany and Schreiber, 1998). The cellular target of lactacystin is the $20 \mathrm{~S}$ proteasome, which is an essential component of the ubiquitin proteasome pathway for intracellular protein degradation (Dick et al., 1996). In the present study, lactacystin was not able to counteract the insulin-induced decrease of the insulin receptor, which indicates that the downregulation of the insulin receptor was not being mediated through proteasomal degradation. This result is not in agreement with experiments in which degradation of the pro-insulin receptor was blocked by lactacystin (Cruz et al., 2004).

Since insulin desensitization was not mediated through proteasomal degradation, a $\beta$ arrestin-coupled degradation mechanism was examined. $\beta$-arrestins are versatile adaptor proteins that form complexes with most seven-transmembrane receptors following agonist binding and receptor phosphorylation by G-protein coupled receptor kinases. Binding of $\beta$ arrestin to the cytoplasmic domain of seven transmembrane receptors interrupts further heterotrimeric G-protein interaction with the receptor, causing signal termination (Usui et al., 2004). Recent studies have shown that $\beta$-arrestins can play a role in the process of heterologous desensitization of receptor tyrosine kinases (RTKs) (Girnita et al., 2003; Girnita et al., 2005). Since insulin downregulates its own signaling pathways (homologous desensitization), and since liganded-insulin receptors associate with $\beta$-arrestin 1 (Dalle et al., 2001), it has been suggested that $\beta$-arrestin could also take part in the insulinmediated desensitization of insulin signaling (i.e. insulin resistance) (Usui et al., 2004). Considering this information, it was hypothesized that binding of $\beta$-arrestin to the insulin 
receptor could occur, and that this process could be followed by endocytosis and ubiquitinmediated degradation of the receptor. Experiments in which InR1G9 cells were treated with insulin for different times showed that two isoforms of $\beta$-arrestin are expressed in this cell line: $\beta$-arrestin 1 and $\beta$-arrestin 2. Furthermore, translocation of $\beta$-arrestin from the cytoplasmic fraction to the membrane fraction was studied, using as a positive control the CC5L-stimulated translocation of $\beta$-arrestin 1 and 2 in rat basophilic leukemia cells (RBL cells) expressing the human chemokine receptor 5 (CCR5) (Hüttenrauch et al., 2005). The results from the current work showed no insulin-induced translocation from the cytoplasmic fraction to the membrane fraction in InR1G9 cells, thus suggesting that the degradation process for the insulin receptor was not mediated through $\beta$-arrestin / insulin receptor translocation followed by ubiquitination.

Given that insulin receptor degradation was not mediated through an interaction of the insulin receptor with $\beta$-arrestin followed by an ubiquitination process, it was suggested that the degradation process could be mediated through lysosomal degradation of the receptor. This kind of degradation can be inhibited by lysosomotropic agents, that are rapidly taken up by cells and are concentrated within lysosomes, where they inactivate proteolytic enzymes by increasing intralysosomal pH (de Duve, 2005; Freychet et al., 1972; Wibo and Poole, 1974). The effect of two lysosomotropic agents, chloroquine and ammonium chloride on insulin receptor degradation was studied in the present work. The lysosomotropic agent chloroquine has been reported to inhibit the normal metabolic processing of both insulin and insulin receptor by inhibiting their lysosomal degradation (Hammons and Jarett, 1980; Heidenreich et al., 1984). In the present study, cells were treated for $9 \mathrm{~h}$ with either of these two substances and for $8 \mathrm{~h}$ with insulin. With these treatment schedules, only chloroquine was able to counteract the insulin-induced downregulation of the insulin receptor. However, extending the time of exposure to these substances to $25 \mathrm{~h}$, and extending insulin treatment to $24 \mathrm{~h}$ resulted in no counteracting effect of chloroquine on the degradation of the insulin receptor. One possible explanation is that the concentration of insulin used for this experiments could be interfering with the effect of chloroquine at prolonged times (Marshall and Olefsky, 1979). It is also known that the effects of chloroquine can vary depending on the time at which this substance is added to the cell culture (Knutson et al., 1985) or depending on the chloroquine concentration used (Bevan et al., 1997). Additionally, in the current investigation upon an extended treatment, chloroquine exerted a detrimental effect on cell viability. Nevertheless, the effect of chloroquine during a short treatment in the current study suggests that the insulin 
receptor degradation may be mediated by lysosomal degradation, at least during the earlier stages of its downregulation.

Insulin receptor substrates are major substrates of the insulin receptor. In vitro and in vivo studies in animal and human models of insulin resistance showed tissue-specific alterations in gene expression and protein levels of insulin receptor substrate 1 and 2 (IRS-1 and IRS-2) (Goodyear et al., 1995; Huang et al., 2002; Kerouz et al., 1997; Rice et al., 1993; Rondinone et al., 1997; Rui et al., 2001; Saad et al., 1992; Sun et al., 1999; Tamemoto et al., 1994; Withers et al., 1998). A reduction in the insulin-stimulated phosphorylation of IRS-1 as well as some polymorphisms of the IRS-1 proteins have been observed in insulin-resistant patients (Thirone et al., 2006). In contrast, few polymorphisms have been found for IRS-2 (Renstrom et al., 2005), thus suggesting IRS-1 as the most relevant isoform regulating metabolic outcomes in muscle and in adipose tissues (Thirone et al., 2006). Therefore, it was of interest to study, whether after chronic insulin treatment the expression and phosphorylation of IRS-1 were modified in $\alpha$-cells. The results of the present work showed upregulation of IRS-1 upon a 10 min insulin treatment as well as downregulation of IRS-1 after a 23 h 10 min insulin treatment, when compared to the basal IRS-1 level. In addition, a shift in electromobility was observed after the different insulin treatments: the $10 \mathrm{~min}$ insulin treatment delayed the migration of IRS-1, while an extended-insulin treatment accelerated its migration. A decrease in IRS-1 and IRS-2 expression levels (Buren et al., 2003; Pirola et al., 2003; Renstrom et al., 2005) as well as changes in electromobility agrees with previous results from other models (Sun et al., 1999). The analysis of tyrosine phosphorylation at residue 612 of IRS-1, which is an essential tyrosine for further interaction with the p85 subunit of PI3K, showed an insulininduced phosphorylation after a $10 \mathrm{~min}$ insulin treatment and a decreased phosphorylation upon an extended insulin treatment. In addition, a slight but similar trend with respect to the electromobility change was observed in the phosphorylation analysis. The phosphorylated IRS-1 migrated faster upon an extended insulin treatment as compared with the migration of the phosphorylated protein after a 10 min insulin treatment. From this data it can be suggested that the decrease in IRS-1 tyrosine phosphorylation was due to a diminished expression level of this protein. Furthermore, the electromobility shift could be caused by changes in phosphorylation, mainly from tyrosine phosphorylation to serine / threonine phosphorylation (Pirola et al., 2003). In a longer run, these phosphorylation changes can lead to proteasomal degradation of IRS-1 (Pederson et al., 2001; Sun et al., 1999). The results of the present work are in concurrence with previous data indicating 
that the delayed electromobility of IRS-1 might be due to an enhanced serine / threonine phosphorylation. This change in phosphorylation is involved in the degradation of IRS-1 (Pederson et al., 2001; Sun et al., 1999). This degradation process disturbs insulin signaling and therefore leads to insulin resistance or to type II diabetes mellitus (Virkamaki et al., 1999).

\subsection{Final concept}

The results presented in the current study suggest a role of chronic insulin treatment and interleukin-1 $\beta$ in the insulin-mediated inhibition of glucagon gene transcription, with the insulin receptor and insulin receptor substrate-1 being critical components in this regulation (Figure 49). Considering that elevated levels of these two substances are present in type II diabetes mellitus and in insulin resistant states, this is the first work at the level of the pancreatic $\alpha$-cell contributing to the understanding of the mechanisms leading to these pathophysiological states. The present work suggests the concept of a "central insulin resistance", since both substances coming from $\beta$-cells, insulin and interleukin 1beta were able to induce an insulin resistant state in $\alpha$-cells. In addition, important pieces of information where obtained for a further explanation of the mechanism leading to insulin resistance at this level. Under healthy conditions insulin is secreted in a pulsatile mode from $\beta$-cells. However, in type II diabetes mellitus insulin pulsation is impaired (Meneilly et al., 2006; Porksen et al., 1997). Therefore, in type II diabetes mellitus a uniform secretion of insulin from $\beta$-cells desensitizes tissues to insulin action. The results of the current study contributed to explain part of this mechanism, by finding that insulin desensitization is caused by downregulation of the insulin receptor in $\alpha$-cells. This downregulation leading to a decreased number of insulin receptors was reflected in a diminished autophosphorylation and thus kinase activity of the receptor thus impairing downstream insulin signaling. Furthermore, it was determined that the downregulation was a reversible and time-dependent process. It was found that downregulation of the receptor involves an enhanced degradation process. Both, degradation through proteasomal as well as through a $\beta$-arrestin coupling degradation processes were excluded. Instead, evidence for a lysosomal degradation of the insulin receptor was found. Chronic insulin treatment not only affected the insulin receptor activity but also interfered with downstream targets within the insulin signaling pathway such as the insulin receptor substrate-1. Insulin receptor 
substrate-1 phosphorylation and expression levels were both downregulated upon an extended insulin treatment.

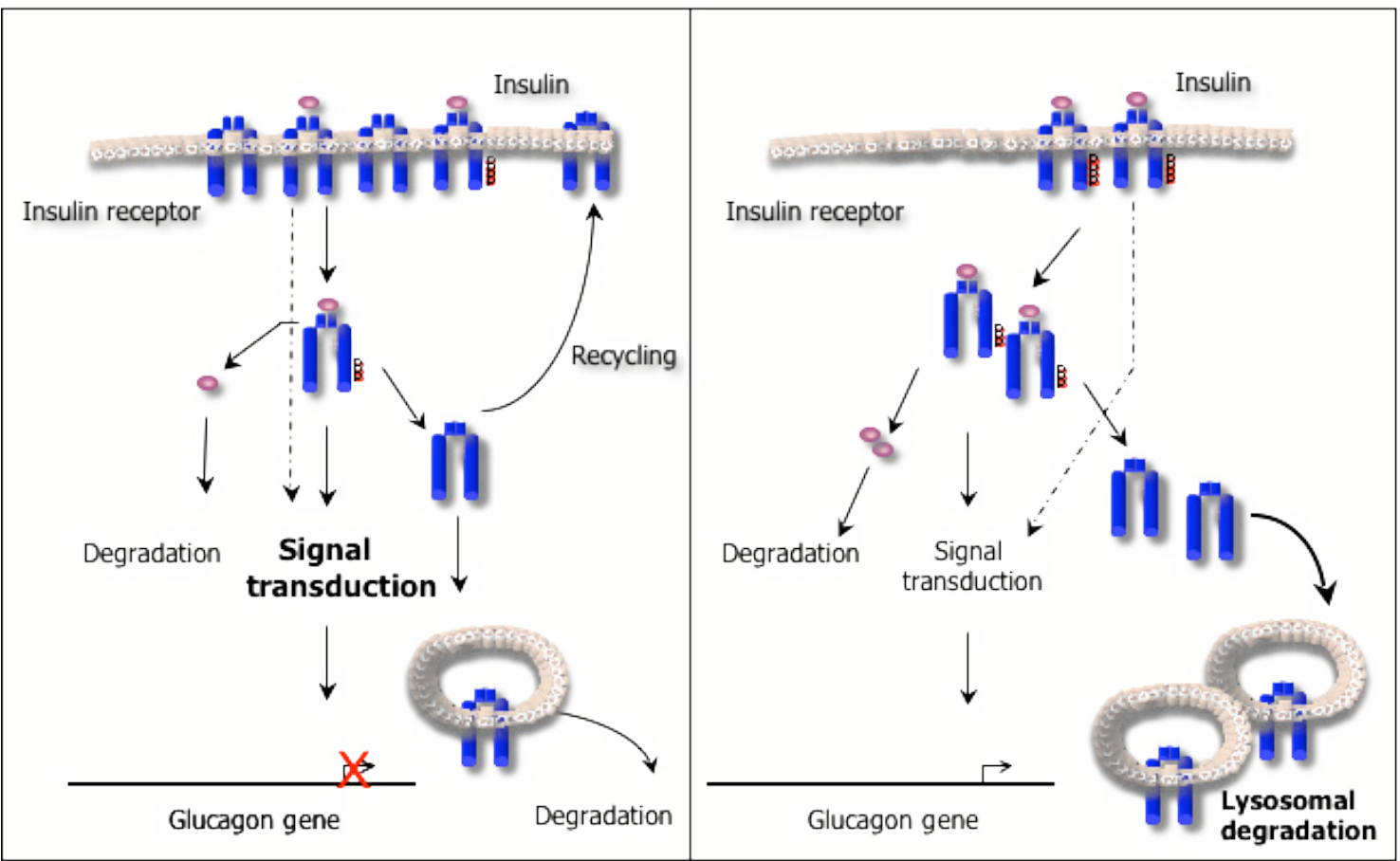

Figure 49. Chronic insulin treatment interferes with the insulin-induced inhibition of glucagon gene transcription in pancreatic islet $\boldsymbol{\alpha}$-cells (hypothesis). Chronic insulin treatment (right panel) interferes with insulin signaling at the level of the insulin receptor (insulin is shown as purple dots and insulin receptor is presented in blue). Chronic insulin treatment downregulates the insulin receptor number in a reversible-time-dependent process. Downregulation of the receptor is mediated through lysosomal degradation. 


\section{REFERENCES}

Anderwald, C., and Roden, M. (2004). Adipotoxicity and the insulin resistance syndrome. Pediatr Endocrinol Rev 1, 310-319.

Argiles, J. M., Lopez-Soriano, J., Ortiz, M. A., Pou, J. M., and Lopez-Soriano, F. J. (1992). Interleukin-1 and beta-cell function: more than one second messenger? Endocr Rev 13, 515-524.

Arner, P. (2005). Insulin resistance in type 2 diabetes - role of the adipokines. Curr Mol Med 5, 333-339.

Balks, H. J., and Jungermann, K. (1984). Regulation of peripheral insulin / glucagon levels by rat liver. Eur J Biochem 141, 645-650.

Bernal-Mizrachi, C., Weng, S., Feng, C., Finck, B. N., Knutsen, R. H., Leone, T. C., Coleman, T., Mecham, R. P., Kelly, D. P., and Semenkovich, C. F. (2003). Dexamethasone induction of hypertension and diabetes is PPAR-alpha dependent in LDL receptor-null mice. Nat Med 9, 1069-1075.

Bertacca, A., Ciccarone, A., Cecchetti, P., Vianello, B., Laurenza, I., Maffei, M., Chiellini, C., Del Prato, S., and Benzi, L. (2005). Continually high insulin levels impair Akt phosphorylation and glucose transport in human myoblasts. Metabolism 54, 1687-1693.

Bevan, A. P., Krook, A., Tikerpae, J., Seabright, P. J., Siddle, K., and Smith, G. D. (1997). Chloroquine extends the lifetime of the activated insulin receptor complex in endosomes. $J$ Biol Chem 272, 26833-26840.

Blackard, W. G., Guzelian, P. S., and Small, M. E. (1978). Down regulation of insulin receptors in primary cultures of adult rat hepatocytes in monolayer. Endocrinology 103, 548-553.

Boron, W. F., and Boulpaep, E. L. (2004). Medical Physiology- Updated Edition (New Haven: Saunders). 1319 pp.

Bruce, J. S., and Salter, A. M. (1996). Metabolic fate of oleic acid, palmitic acid and stearic acid in cultured hamster hepatocytes. Biochem J 316 (Pt 3), 847-852.

Buchanan, K. D. (1976). The role of enteric hormones in glucose homeostasis. Horm Metab Res 6, 80-84.

Buren, J., and Eriksson, J. W. (2005). Is insulin resistance caused by defects in insulin's target cells or by a stressed mind? Diabetes Metab Res Rev 21, 487-494.

Buren, J., Liu, H. X., Lauritz, J., and Eriksson, J. W. (2003). High glucose and insulin in combination cause insulin receptor substrate-1 and -2 depletion and protein kinase $B$ desensitisation in primary cultured rat adipocytes: possible implications for insulin resistance in type 2 diabetes. Eur J Endocrinol 148, 157-167.

Callaerts, P., Halder, G., and Gehring, W. J. (1997). PAX-6 in development and evolution. Annu Rev Neurosci 20, 483-532. 
Capeau, J. (2003). [Insulin signaling: mechanisms altered in insulin resistance]. Med Sci (Paris) 19, 834-839.

Capeau, J. (2005). [Insulin signaling: mechanisms altered in insulin resistance]. Med Sci (Paris) 21 Spec No, 34-39.

Carpentier, J. L., Gorden, P., and Lew, D. P. (1992). Calcium ions are required for the intracellular routing of insulin and its receptor. Exp Cell Res 198, 144-149.

Chakraborty, C. (2006). Biochemical and molecular basis of insulin resistance. Curr Protein Pept Sci 7, 113-121.

Chavez, J. A., and Summers, S. A. (2003). Characterizing the effects of saturated fatty acids on insulin signaling and ceramide and diacylglycerol accumulation in 3T3-L1 adipocytes and C2C12 myotubes. Arch Biochem Biophys 419, 101-109.

Cho, H., Mu, J., Kim, J. K., Thorvaldsen, J. L., Chu, Q., Crenshaw, E. B., 3rd, Kaestner, K. H., Bartolomei, M. S., Shulman, G. I., and Birnbaum, M. J. (2001). Insulin resistance and a diabetes mellitus-like syndrome in mice lacking the protein kinase Akt2 (PKB beta). Science 292, 1728-1731.

Cordier-Bussat, M., Morel, C., and Philippe, J. (1995). Homologous DNA sequences and cellular factors are implicated in the control of glucagon and insulin gene expression. $\mathrm{Mol}$ Cell Biol 15, 3904-3916.

Cruz, M., Velasco, E., and Kumate, J. (2004). Degradation of pro-insulin-receptor proteins by proteasomes. Arch Med Res 35, 18-23.

Czech, M. P. (1977). Molecular basis of insulin action. Annu Rev Biochem 46, 359-384.

Dalle, S., Ricketts, W., Imamura, T., Vollenweider, P., and Olefsky, J. M. (2001). Insulin and insulin-like growth factor I receptors utilize different $G$ protein signaling components. $J$ Biol Chem 276, 15688-15695.

Darling, G., Goldstein, D. S., Stull, R., Gorschboth, C. M., and Norton, J. A. (1989). Tumor necrosis factor: immune endocrine interaction. Surgery 106, 1155-1160.

Day, C. (1999). Thiazolidinediones: a new class of antidiabetic drugs. Diabet Med 16, 179192.

de Duve, C. (2005). [The lysosome turns fifty.]. Med Sci (Paris) 21, 12-15.

DeFronzo, R. A. (1988). Lilly lecture 1987. The triumvirate: beta-cell, muscle, liver. A collusion responsible for NIDDM. Diabetes 37, 667-687.

DeFronzo, R. A. (1997). Insulin resistance: a multifaceted syndrome responsible for NIDDM, obesity, hypertension, dyslipidaemia and atherosclerosis. Neth J Med 50, 191197.

Dey, D., Basu, D., Roy, S. S., Bandyopadhyay, A., and Bhattacharya, S. (2006). Involvement of novel PKC isoforms in FFA induced defects in insulin signaling. Mol Cell Endocrinol 246, 60-64. 
Dey, D., Mukherjee, M., Basu, D., Datta, M., Roy, S. S., Bandyopadhyay, A., and Bhattacharya, S. (2005). Inhibition of insulin receptor gene expression and insulin signaling by fatty acid: interplay of PKC isoforms therein. Cell Physiol Biochem 16, 217228.

Diamond, J. (2003). The double puzzle of diabetes. Nature 423, 599-602.

Dick, L. R., Cruikshank, A. A., Grenier, L., Melandri, F. D., Nunes, S. L., and Stein, R. L. (1996). Mechanistic studies on the inactivation of the proteasome by lactacystin: a central role for clasto-lactacystin beta-lactone. J Biol Chem 271, 7273-7276.

Dimopoulos, N. (2003) Role for glycogen synthase kinase 3 beta in the regulation of glucagon gene transcription by insulin, Georg August University-Goettingen, Goettingen. PhD Thesis.

Draznin, B. (2006). Molecular Mechanisms of Insulin Resistance: Serine Phosphorylation of Insulin Receptor Substrate-1 and Increased Expression of p85\{alpha\}: The Two Sides of a Coin. Diabetes 55, 2392-2397.

Dröge, W. (2005). Oxidative enhancement of insulin receptor signaling: experimental findings and clinical implications. Antioxid Redox Signal 7, 1071-1077.

Drucker, D. J. (1998). Glucagon-like peptides. Diabetes 47, 159-169.

Drucker, D. J., Philippe, J., Jepeal, L., and Habener, J. F. (1987a). cis-acting DNA sequence controls glucagon gene expression in pancreatic islet cells. Trans Assoc Am Physicians 100, 109-115.

Drucker, D. J., Philippe, J., Jepeal, L., and Habener, J. F. (1987b). Glucagon gene 5'flanking sequences promote islet cell-specific gene transcription. J Biol Chem 262, 1565915665.

Du, K., Herzig, S., Kulkarni, R. N., and Montminy, M. (2003). TRB3: a tribbles homolog that inhibits Akt / PKB activation by insulin in liver. Science 300, 1574-1577.

Efrat, S., Teitelman, G., Anwar, M., Ruggiero, D., and Hanahan, D. (1988). Glucagon gene regulatory region directs oncoprotein expression to neurons and pancreatic alpha cells. Neuron 1, 605-613.

Emanuelli, B., Glondu, M., Filloux, C., Peraldi, P., and Van Obberghen, E. (2004). The potential role of SOCS-3 in the interleukin-1beta-induced desensitization of insulin signaling in pancreatic beta-cells. Diabetes 53 Suppl 3, S97-S103.

Evans, J. L., Goldfine, I. D., Maddux, B. A., and Grodsky, G. M. (2002). Oxidative stress and stress-activated signaling pathways: a unifying hypothesis of type 2 diabetes. Endocr Rev 23, 599-622.

Evans, J. L., Maddux, B. A., and Goldfine, I. D. (2005). The molecular basis for oxidative stress-induced insulin resistance. Antioxid Redox Signal 7, 1040-1052.

Fanelli, C. G., Porcellati, F., Rossetti, P., and Bolli, G. B. (2006). Glucagon: the effects of its excess and deficiency on insulin action. Nutr Metab Cardiovasc Dis 16 Suppl 1, S28-34. 
Fenteany, G., and Schreiber, S. L. (1998). Lactacystin, proteasome function, and cell fate. J Biol Chem 273, 8545-8548.

Figueiredo-Pereira, M. E., Berg, K. A., and Wilk, S. (1994). A new inhibitor of the chymotrypsin-like activity of the multicatalytic proteinase complex (20S proteasome) induces accumulation of ubiquitin-protein conjugates in a neuronal cell. $J$ Neurochem 63 , 1578-1581.

Forman, B. M., Chen, J., and Evans, R. M. (1997). Hypolipidemic drugs, polyunsaturated fatty acids, and eicosanoids are ligands for peroxisome proliferator-activated receptors alpha and delta. Proc Natl Acad Sci U S A 94, 4312-4317.

Forman, B. M., Tontonoz, P., Chen, J., Brun, R. P., Spiegelman, B. M., and Evans, R. M. (1995). 15-Deoxy-delta 12, 14-prostaglandin J2 is a ligand for the adipocyte determination factor PPAR gamma. Cell 83, 803-812.

Frame, S., Cohen, P., and Biondi, R. M. (2001). A common phosphate binding site explains the unique substrate specificity of GSK3 and its inactivation by phosphorylation. Mol Cell 7, 1321-1327.

Freychet, P., Kahn, R., Roth, J., and Neville, D. M., Jr. (1972). Insulin interactions with liver plasma membranes. Independence of binding of the hormone and its degradation. $J$ Biol Chem 247, 3953-3961.

Fujishiro, M., Gotoh, Y., Katagiri, H., Sakoda, H., Ogihara, T., Anai, M., Onishi, Y., Ono, H., Funaki, M., Inukai, K., et al. (2001). MKK6 / 3 and p38 MAPK pathway activation is not necessary for insulin-induced glucose uptake but regulates glucose transporter expression. J Biol Chem 276, 19800-19806.

Fürnsinn, C., Neschen, S., Wagner, O., Roden, M., Bisschop, M., and Waldhausl, W. (1997). Acute and chronic exposure to tumor necrosis factor-alpha fails to affect insulinstimulated glucose metabolism of isolated rat soleus muscle. Endocrinology 138, 26742679.

Fürstenau, U., Schwaninger, M., Blume, R., Jendrusch, E. M., and Knepel, W. (1999). Characterization of a novel calcium response element in the glucagon gene. $J$ Biol Chem 274, 5851-5860.

Garvey, W. T., Huecksteadt, T. P., Monzon, R., and Marshall, S. (1989). Dexamethasone regulates the glucose transport system in primary cultured adipocytes: different mechanisms of insulin resistance after acute and chronic exposure. Endocrinology 124, 2063-2073.

George, S., Rochford, J. J., Wolfrum, C., Gray, S. L., Schinner, S., Wilson, J. C., Soos, M. A., Murgatroyd, P. R., Williams, R. M., Acerini, C. L., et al. (2004). A family with severe insulin resistance and diabetes due to a mutation in AKT2. Science 304, 1325-1328.

Gerich, J. E. (1981). Physiology of glucagon. Int Rev Physiol 24, 243-275.

Girnita, L., Girnita, A., and Larsson, O. (2003). Mdm2-dependent ubiquitination and degradation of the insulin-like growth factor 1 receptor. Proc Natl Acad Sci US A 100, 8247-8252. 
Girnita, L., Shenoy, S. K., Sehat, B., Vasilcanu, R., Girnita, A., Lefkowitz, R. J., and Larsson, O. (2005). \{beta\}-Arrestin is crucial for ubiquitination and down-regulation of the insulin-like growth factor-1 receptor by acting as adaptor for the MDM2 E3 ligase. $J$ Biol Chem 280, 24412-24419.

Glickman, M. H., and Ciechanover, A. (2002). The ubiquitin-proteasome proteolytic pathway: destruction for the sake of construction. Physiol Rev 82, 373-428.

Goodyear, L. J., Giorgino, F., Sherman, L. A., Carey, J., Smith, R. J., and Dohm, G. L. (1995). Insulin receptor phosphorylation, insulin receptor substrate-1 phosphorylation, and phosphatidylinositol 3-kinase activity are decreased in intact skeletal muscle strips from obese subjects. J Clin Invest 95, 2195-2204.

Grell, M., Wajant, H., Zimmermann, G., and Scheurich, P. (1998). The type 1 receptor (CD120a) is the high-affinity receptor for soluble tumor necrosis factor. Proc Natl Acad Sci U S A 95, 570-575.

Griffin, M. E., Marcucci, M. J., Cline, G. W., Bell, K., Barucci, N., Lee, D., Goodyear, L. J., Kraegen, E. W., White, M. F., and Shulman, G. I. (1999). Free fatty acid-induced insulin resistance is associated with activation of protein kinase $\mathrm{C}$ theta and alterations in the insulin signaling cascade. Diabetes 48, 1270-1274.

Grimaldi, P. A. (2001). The roles of PPARs in adipocyte differentiation. Prog Lipid Res 40, 269-281.

Grzelkowska-Kowalczyk, K., and Wieteska-Skrzeczynska, W. (2006). Exposure to TNFalpha but not IL-1beta impairs insulin-dependent phosphorylation of protein kinase $\mathrm{B}$ and p70S6k in mouse C2C12 myogenic cells. Pol J Vet Sci 9, 1-10.

Grzeskowiak, R., Amin, J., Oetjen, E., and Knepel, W. (2000). Insulin responsiveness of the glucagon gene conferred by interactions between proximal promoter and more distal enhancer-like elements involving the paired-domain transcription factor Pax6. J Biol Chem 275, 30037-30045.

Guerre-Millo, M. (2004). Adipose tissue and adipokines: for better or worse. Diabetes Metab 30, 13-19.

Habener, J. F., Miller, C. P., and Vallejo, M. (1995). cAMP-dependent regulation of gene transcription by cAMP response element-binding protein and CAMP response element modulator. Vitam Horm 51, 1-57.

Haber, E. P., Ximenes, H. M., Procopio, J., Carvalho, C. R., Curi, R., and Carpinelli, A. R. (2003). Pleiotropic effects of fatty acids on pancreatic beta-cells. J Cell Physiol 194, 1-12.

Hammarstedt, A., Andersson, C. X., Rotter Sopasakis, V., and Smith, U. (2005). The effect of PPAR gamma ligands on the adipose tissue in insulin resistance. Prostaglandins Leukot Essent Fatty Acids 73, 65-75.

Hammons, G. T., and Jarett, L. (1980). Lysosomal degradation of receptor-bound 125Ilabeled insulin by rat adipocytes: its characterization and dissociation from the short-term biologic effects of insulin. Diabetes 29, 475-486. 
Heaton, J. H., and Gelehrter, T. D. (1981). Desensitization of hepatoma cells to insulin action. Evidence for a post-receptor mechanism. J Biol Chem 256, 12257-12262.

Heidenreich, K. A., Brandenburg, D., Berhanu, P., and Olefsky, J. M. (1984). Metabolism of photoaffinity-labeled insulin receptors by adipocytes. Role of internalization, degradation, and recycling. J Biol Chem 259, 6511-6515.

Hotamisligil, G. S. (1999). Mechanisms of TNF-alpha-induced insulin resistance. Exp Clin Endocrinol Diabetes 107, 119-125.

Hotamisligil, G. S. (2000). Molecular mechanisms of insulin resistance and the role of the adipocyte. Int J Obes Relat Metab Disord 24 Suppl 4, S23-27.

Hotamisligil, G. S., Murray, D. L., Choy, L. N., and Spiegelman, B. M. (1994). Tumor necrosis factor alpha inhibits signaling from the insulin receptor. Proc Natl Acad Sci U $S A$ 91, 4854-4858.

Howard, C. F. (1985). Atherosclerosis and insulin in primates with diabetes mellitus. Metabolism 34, 60-66.

Huang, H. P., and Tsai, M. J. (2000). Transcription factors involved in pancreatic islet development. J Biomed Sci 7, 27-34.

Huang, X., Vaag, A., Hansson, M., and Groop, L. (2002). Down-regulation of insulin receptor substrates (IRS)-1 and IRS-2 and Src homologous and collagen-like protein Shc gene expression by insulin in skeletal muscle is not associated with insulin resistance or type 2 diabetes. J Clin Endocrinol Metab 87, 255-259.

Hubbard, S. R. (1997). Crystal structure of the activated insulin receptor tyrosine kinase in complex with peptide substrate and ATP analog. Embo J 16, 5572-5581.

Hug, C., and Lodish, H. F. (2005). Medicine. Visfatin: a new adipokine. Science 307, 366367.

Hussain, M. A., and Habener, J. F. (1999). Glucagon gene transcription activation mediated by synergistic interactions of pax-6 and cdx-2 with the p300 co-activator. $J$ Biol Chem 274, 28950-28957.

Hüttenrauch, F., Pollok-Kopp, B., and Oppermann, M. (2005). G protein-coupled receptor kinases promote phosphorylation and beta-arrestin-mediated internalization of CCR5 homo- and hetero-oligomers. J Biol Chem 280, 37503-37515.

Ishikawa, T., and Morris, P. L. (2006). Interleukin-1\{beta\} Signals Through a cJun-Nterminal kinase (JNK)-dependent Inducible Nitric Oxide Synthase and Nitric Oxide Production Pathway in Sertoli Epithelial Cells. Endocrinology. Ahead of print.

Jazet, I. M., Pijl, H., and Meinders, A. E. (2003). Adipose tissue as an endocrine organ: impact on insulin resistance. Neth J Med 61, 194-212.

Jensen, T. J., Loo, M. A., Pind, S., Williams, D. B., Goldberg, A. L., and Riordan, J. R. (1995). Multiple proteolytic systems, including the proteasome, contribute to CFTR processing. Cell 83, 129-135. 
Jiang, G., and Zhang, B. B. (2003). Glucagon and regulation of glucose metabolism. Am J Physiol Endocrinol Metab 284, E671-678.

Kadowaki, T., and Yamauchi, T. (2005). Adiponectin and adiponectin receptors. Endocr Rev 26, 439-451.

Karpe, F., and Tan, G. D. (2005). Adipose tissue function in the insulin-resistance syndrome. Biochem Soc Trans 33, 1045-1048.

Katso, R., Okkenhaug, K., Ahmadi, K., White, S., Timms, J., and Waterfield, M. D. (2001). Cellular function of phosphoinositide 3-kinases: implications for development, homeostasis, and cancer. Annu Rev Cell Dev Biol 17, 615-675.

Kerouz, N. J., Horsch, D., Pons, S., and Kahn, C. R. (1997). Differential regulation of insulin receptor substrates-1 and -2 (IRS-1 and IRS-2) and phosphatidylinositol 3-kinase isoforms in liver and muscle of the obese diabetic (ob / ob) mouse. J Clin Invest 100, 3164-3172.

Kisanuki, K., Kishikawa, H., Araki, E., Shirotani, T., Uehara, M., Isami, S., Ura, S., Jinnouchi, H., Miyamura, N., and Shichiri, M. (1995). Expression of insulin receptor on clonal pancreatic alpha cells and its possible role for insulin-stimulated negative regulation of glucagon secretion. Diabetologia 38, 422-429.

Kliewer, S. A., Lenhard, J. M., Willson, T. M., Patel, I., Morris, D. C., and Lehmann, J. M. (1995). A prostaglandin J2 metabolite binds peroxisome proliferator-activated receptor gamma and promotes adipocyte differentiation. Cell 83, 813-819.

Kliewer, S. A., Sundseth, S. S., Jones, S. A., Brown, P. J., Wisely, G. B., Koble, C. S., Devchand, P., Wahli, W., Willson, T. M., Lenhard, J. M., and Lehmann, J. M. (1997). Fatty acids and eicosanoids regulate gene expression through direct interactions with peroxisome proliferator-activated receptors alpha and gamma. Proc Natl Acad Sci U S A 94, 4318-4323.

Knepel, W. (1993). Transcriptional control of pancreatic islet hormones gene expression. Exp Clin Endocrinol 101, 39-45.

Knepel, W., Chafitz, J., and Habener, J. F. (1990). Transcriptional activation of the rat glucagon gene by the cyclic AMP-responsive element in pancreatic islet cells. Mol Cell Biol 10, 6799-6804.

Knutson, V. P. (1991). Proteolytic processing of the insulin receptor beta subunit is associated with insulin-induced receptor down-regulation. J Biol Chem 266, 15656-15662.

Knutson, V. P., Ronnett, G. V., and Lane, M. D. (1983). Rapid, reversible internalization of cell surface insulin receptors. Correlation with insulin-induced down-regulation. $J$ Biol Chem 258, 12139-12142.

Knutson, V. P., Ronnett, G. V., and Lane, M. D. (1985). The effects of cycloheximide and chloroquine on insulin receptor metabolism. Differential effects on receptor recycling and inactivation and insulin degradation. J Biol Chem 260, 14180-14188. 
Koo, S. H., Satoh, H., Herzig, S., Lee, C. H., Hedrick, S., Kulkarni, R., Evans, R. M., Olefsky, J., and Montminy, M. (2004). PGC-1 promotes insulin resistance in liver through PPAR-alpha-dependent induction of TRB-3. Nat Med 10, 530-534.

Krey, G., Braissant, O., L'Horset, F., Kalkhoven, E., Perroud, M., Parker, M. G., and Wahli, W. (1997). Fatty acids, eicosanoids, and hypolipidemic agents identified as ligands of peroxisome proliferator-activated receptors by coactivator-dependent receptor ligand assay. Mol Endocrinol 11, 779-791.

Krook, A., Roth, R. A., Jiang, X. J., Zierath, J. R., and Wallberg-Henriksson, H. (1998). Insulin-stimulated Akt kinase activity is reduced in skeletal muscle from NIDDM subjects. Diabetes 47, 1281-1286.

Kumar, S., and O'Rahily, S. (2005). Insulin Resistance: Insulin action and its disturbances in disease (England: Wiley). 599 pp.

Lambillotte, C., Gilon, P., and Henquin, J. C. (1997). Direct glucocorticoid inhibition of insulin secretion. An in vitro study of dexamethasone effects in mouse islets. $J$ Clin Invest 99, 414-423.

Laser, B., Meda, P., Constant, I., and Philippe, J. (1996). The caudal-related homeodomain protein $\mathrm{Cdx}-2$ / 3 regulates glucagon gene expression in islet cells. $\mathrm{J}$ Biol Chem 271, 28984-28994.

Lebovitz, H. E., and Feinglos, M. N. (1980). Therapy of insulin-independent diabetes mellitus: General considerations. Metabolism 29, 474-481.

Lee, Y. C., Asa, S. L., and Drucker, D. J. (1992). Glucagon gene 5'-flanking sequences direct expression of simian virus 40 large $T$ antigen to the intestine, producing carcinoma of the large bowel in transgenic mice. J Biol Chem 267, 10705-10708.

Lefebvre, P. J. (1995). Glucagon and its family revisited. Diabetes Care 18, 715-730.

Lehmann, J. M., Moore, L. B., Smith-Oliver, T. A., Wilkison, W. O., Willson, T. M., and Kliewer, S. A. (1995). An antidiabetic thiazolidinedione is a high affinity ligand for peroxisome proliferator-activated receptor gamma (PPAR gamma). J Biol Chem 270, 12953-12956.

Livingston, J. N., Purvis, B. J., and D.H., L. (1978a). Insulin induced changes in insulin binding and insulin-sensitivity of adipocytes. Metabolism 27, 2009-2014.

Livingston, J. N., Purvis, B. J., and Lockwood, D. H. (1978b). Insulin-dependent regulation of the insulin-sensitivity of adipocytes. Nature 273, 394-396.

Lodish, H., Berk, A., Zipursky, L., Matsudaira, P., Baltimore, D., and Darnell, J. (2000). Molecular Cell Biology: W.H. Freeman and Company). 1084 pp.

Lundgren, M., and Eriksson, J. W. (2004). No in vitro effects of fatty acids on glucose uptake, lipolysis or insulin signaling in rat adipocytes. Horm Metab Res 36, 203-209.

MacEwan, D. J. (2002). TNF receptor subtype signalling: differences and cellular consequences. Cell Signal 14, 477-492. 
Maedler, K., and Donath, M. Y. (2004). Beta-cells in type 2 diabetes: a loss of function and mass. Horm Res 62 Supp/ 3, 67-73.

Maedler, K., Storling, J., Sturis, J., Zuellig, R. A., Spinas, G. A., Arkhammar, P. O., Mandrup-Poulsen, T., and Donath, M. Y. (2004). Glucose- and interleukin-1beta-induced beta-cell apoptosis requires Ca2+ influx and extracellular signal-regulated kinase (ERK) 1 / 2 activation and is prevented by a sulfonylurea receptor 1 / inwardly rectifying $\mathrm{K}+$ channel 6.2 (SUR / Kir6.2) selective potassium channel opener in human islets. Diabetes 53, 17061713.

Marchetti, P., and Navalesi, R. (2000). The metabolic effects of cyclosporin and tacrolimus. J Endocrinol Invest 23, 482-490.

Marshall, S., and Olefsky, J. M. (1979). Effects of lysosomotropic agents on insulin interactions with adipocytes. Evidence for a lysosomal pathway for insulin processing and degradation. J Biol Chem 254, 10153-10160.

Mayr, B. M., Canettieri, G., and Montminy, M. R. (2001). Distinct effects of cAMP and mitogenic signals on CREB-binding protein recruitment impart specificity to target gene activation via CREB. Proc Natl Acad Sci U S A 98, 10936-10941.

Meneilly, G. S., Veldhuis, J. D., and Elahi, D. (2006). Pulsatile insulin secretion in elderly patients with diabetes. Diabetes Res Clin Pract 73, 218-220.

Mevorach, M., Giacca, A., Aharon, Y., Hawkins, M., Shamoon, H., and Rossetti, L. (1998). Regulation of endogenous glucose production by glucose per se is impaired in type 2 diabetes mellitus. J Clin Invest 102, 744-753.

Moraes, L. A., Piqueras, L., and Bishop-Bailey, D. (2006). Peroxisome proliferatoractivated receptors and inflammation. Pharmacol Ther 110, 371-385.

Mott, D. M., Howard, B. V., and Bennett, P. H. (1979). Stoichiometric binding and regulation of insulin receptors on human diploid fibroblasts using physiologic insulin levels. J Biol Chem 254, 8762-8767.

Musi, N., and Goodyear, L. J. (2006). Insulin resistance and improvements in signal transduction. Endocrine 29, 73-80.

Nerup, J., Mandrup-Poulsen, T., Helqvist, S., Andersen, H. U., Pociot, F., Reimers, J. I., Cuartero, B. G., Karlsen, A. E., Bjerre, U., and Lorenzen, T. (1994). On the pathogenesis of IDDM. Diabetologia 37 Suppl 2, S82-89.

Nunez, E. A. (1997). Biological complexity is under the 'strange attraction' of non-esterified fatty acids. Prostaglandins Leukot Essent Fatty Acids 57, 107-110.

Oetjen, E., Baun, D., Beimesche, S., Krause, D., Cierny, I., Blume, R., Dickel, C., Wehner, S., and Knepel, W. (2003a). Inhibition of human insulin gene transcription by the immunosuppressive drugs cyclosporin $A$ and tacrolimus in primary, mature islets of transgenic mice. Mol Pharmacol 63, 1289-1295. 
Oetjen, E., Grapentin, D., Blume, R., Seeger, M., Krause, D., Eggers, A., and Knepel, W. (2003b). Regulation of human insulin gene transcription by the immunosuppressive drugs cyclosporin A and tacrolimus at concentrations that inhibit calcineurin activity and involving the transcription factor CREB. Naunyn Schmiedebergs Arch Pharmacol367, 227-236.

Ohashi, A., Matsushita, Y., Kimura, K., Miyashita, K., and Saito, M. (2004). Conjugated linoleic acid deteriorates insulin resistance in obese / diabetic mice in association with decreased production of adiponectin and leptin. J Nutr Sci Vitaminol (Tokyo) 50, 416-421.

Olefsky, J. M. (2000). Treatment of insulin resistance with peroxisome proliferatoractivated receptor gamma agonists. J Clin Invest 106, 467-472.

Olefsky, J. M., and Saltiel, A. R. (2000). PPAR gamma and the treatment of insulin resistance. Trends Endocrinol Metab 11, 362-368.

Ottensmeyer, F. P., Beniac, D. R., Luo, R. Z., and Yip, C. C. (2000). Mechanism of transmembrane signaling: insulin binding and the insulin receptor. Biochemistry 39, 1210312112.

Patel, S., Doble, B., and Woodgett, J. R. (2004). Glycogen synthase kinase-3 in insulin and Wnt signalling: a double-edged sword? Biochem Soc Trans 32, 803-808.

Pederson, T. M., Kramer, D. L., and Rondinone, C. M. (2001). Serine / threonine phosphorylation of IRS-1 triggers its degradation: possible regulation by tyrosine phosphorylation. Diabetes 50, 24-31.

Perseghin, G., Ghosh, S., Gerow, K., and Shulman, G. I. (1997). Metabolic defects in lean nondiabetic offspring of NIDDM parents: a cross-sectional study. Diabetes 46, 1001-1009.

Philippe, J. (1989). Glucagon gene transcription is negatively regulated by insulin in a hamster islet cell line. J Clin Invest 84, 672-677.

Philippe, J. (1991). Structure and pancreatic expression of the insulin and glucagon genes. Endocr Rev 12, 252-271.

Philippe, J., Drucker, D. J., and Habener, J. F. (1987). Glucagon gene transcription in an islet cell line is regulated via a protein kinase C-activated pathway. $J$ Biol Chem 262, 18231828.

Philippe, J., Drucker, D. J., Knepel, W., Jepeal, L., Misulovin, Z., and Habener, J. F. (1988). Alpha-cell-specific expression of the glucagon gene is conferred to the glucagon promoter element by the interactions of DNA-binding proteins. Mol Cell Biol 8, 4877-4888.

Philippe, J., Morel, C., and Cordier-Bussat, M. (1995). Islet-specific proteins interact with the insulin-response element of the glucagon gene. J Biol Chem 270, 3039-3045.

Pickup, J. C., Chusney, G. D., Thomas, S. M., and Burt, D. (2000). Plasma interleukin-6, tumour necrosis factor alpha and blood cytokine production in type 2 diabetes. Life Sci 67, 291-300. 
Pirola, L., Bonnafous, S., Johnston, A. M., Chaussade, C., Portis, F., and Van Obberghen, E. (2003). Phosphoinositide 3-kinase-mediated reduction of insulin receptor substrate-1/2 protein expression via different mechanisms contributes to the insulin-induced desensitization of its signaling pathways in L6 muscle cells. J Biol Chem 278, 15641 15651.

Porksen, N., Nyholm, B., Veldhuis, J. D., Butler, P. C., and Schmitz, O. (1997). In humans at least $75 \%$ of insulin secretion arises from punctuated insulin secretory bursts. $A m J$ Physiol 273, E908-914.

Qi, C., and Pekala, P. H. (2000). Tumor necrosis factor-alpha-induced insulin resistance in adipocytes. Proc Soc Exp Biol Med 223, 128-135.

Qiu, W., Taghibiglou, C., Avramoglu, R. K., Van Iderstine, S. C., Naples, M., Ashrafpour, H., Mhapsekar, S., Sato, R., and Adeli, K. (2005). Oleate-mediated stimulation of microsomal triglyceride transfer protein (MTP) gene promoter: implications for hepatic MTP overexpression in insulin resistance. Biochemistry 44, 3041-3049.

Randle, P. J., Garland, P. B., Hales, C. N., and Newsholme, E. A. (1963). The glucose fatty-acid cycle. Its role in insulin sensitivity and the metabolic disturbances of diabetes mellitus. Lancet 1, 785-789.

Randle, P. J., Priestman, D. A., Mistry, S. C., and Halsall, A. (1994). Glucose fatty acid interactions and the regulation of glucose disposal. $J$ Cell Biochem 55 Suppl, 1-11.

Rangwala, S. M., and Lazar, M. A. (2004). Peroxisome proliferator-activated receptor gamma in diabetes and metabolism. Trends Pharmacol Sci 25, 331-336.

Ravazzola, M., and Orci, L. (1979). [Immunocytochemical anatomy of alpha granules in the human endocrine pancreas]. C R Seances Acad Sci D 289, 1161-1162.

Ravazzola, M., Unger, R. H., and Orci, L. (1981). Demonstration of glucagon in the stomach of human fetuses. Diabetes 30, 879-882.

Reach, G., and Assan, R. (1979). Glucagon and diabetes mellitus. Diabetes Metab 5, 6370.

Rebrin, K., Steil, G. M., Getty, L., and Bergman, R. N. (1995). Free fatty acid as a link in the regulation of hepatic glucose output by peripheral insulin. Diabetes 44, 1038-1045.

Reimers, J. I., Bjerre, U., Mandrup-Poulsen, T., and Nerup, J. (1994). Interleukin 1 beta induces diabetes and fever in normal rats by nitric oxide via induction of different nitric oxide synthases. Cytokine 6, 512-520.

Renström, F., Buren, J., and Eriksson, J. W. (2005). Insulin receptor substrates-1 and -2 are both depleted but via different mechanisms after down-regulation of glucose transport in rat adipocytes. Endocrinology 146, 3044-3051.

Rice, K. M., Turnbow, M. A., and Garner, C. W. (1993). Insulin stimulates the degradation of IRS-1 in 3T3-L1 adipocytes. Biochem Biophys Res Commun 190, 961-967. 
Rome, S., Meugnier, E., and Vidal, H. (2004). The ubiquitin-proteasome pathway is a new partner for the control of insulin signaling. Curr Opin Clin Nutr Metab Care 7, 249-254.

Rondinone, C. M., and Kramer, D. (2002). Proteasome inhibitors regulate tyrosine phosphorylation of IRS-1 and insulin signaling in adipocytes. Biochem Biophys Res Commun 296, 1257-1263.

Rondinone, C. M., Wang, L. M., Lonnroth, P., Wesslau, C., Pierce, J. H., and Smith, U. (1997). Insulin receptor substrate (IRS) 1 is reduced and IRS-2 is the main docking protein for phosphatidylinositol 3-kinase in adipocytes from subjects with non-insulin-dependent diabetes mellitus. Proc Natl Acad Sci U S A 94, 4171-4175.

Ronnett, G. V., Knutson, V. P., and Lane, M. D. (1982). Insulin-induced down-regulation of insulin receptors in 3T3-L1 adipocytes. Altered rate of receptor inactivation. $J$ Biol Chem 257, 4285-4291.

Ronti, T., Lupattelli, G., and Mannarino, E. (2006). The endocrine function of adipose tissue: an update. Clin Endocrinol (Oxf) 64, 355-365.

Rosen, O. M., Herrera, R., Olowe, Y., Petruzzelli, L. M., and Cobb, M. H. (1983). Phosphorylation activates the insulin receptor tyrosine protein kinase. Proc Natl Acad Sci U S A 80, 3237-3240.

Rotter, V., Nagaev, I., and Smith, U. (2003). Interleukin-6 (IL-6) induces insulin resistance in 3T3-L1 adipocytes and is, like IL-8 and tumor necrosis factor-alpha, overexpressed in human fat cells from insulin-resistant subjects. J Biol Chem 278, 45777-45784.

Rui, L., Fisher, T. L., Thomas, J., and White, M. F. (2001). Regulation of insulin / insulinlike growth factor-1 signaling by proteasome-mediated degradation of insulin receptor substrate-2. J Biol Chem 276, 40362-40367.

Saad, M. J., Araki, E., Miralpeix, M., Rothenberg, P. L., White, M. F., and Kahn, C. R. (1992). Regulation of insulin receptor substrate-1 in liver and muscle of animal models of insulin resistance. J Clin Invest 90, 1839-1849.

Saltiel, A. R., and Kahn, C. R. (2001). Insulin signalling and the regulation of glucose and lipid metabolism. Nature 414, 799-806.

Schinner, S., Barthel, A., Dellas, C., Grzeskowiak, R., Sharma, S. K., Oetjen, E., Blume, R., and Knepel, W. (2005a). Protein kinase B activity is sufficient to mimic the effect of insulin on glucagon gene transcription. J Biol Chem 280, 7369-7376.

Schinner, S., Dellas, C., Schroder, M., Heinlein, C. A., Chang, C., Fischer, J., and Knepel, W. (2002). Repression of glucagon gene transcription by peroxisome proliferator-activated receptor gamma through inhibition of Pax6 transcriptional activity. J Biol Chem 277, 19411948.

Schinner, S., Scherbaum, W. A., Bornstein, S. R., and Barthel, A. (2005b). Molecular mechanisms of insulin resistance. Diabet Med 22, 674-682.

Schmitz-Peiffer, C. (2002). Protein kinase C and lipid-induced insulin resistance in skeletal muscle. Ann N Y Acad Sci 967, 146-157. 
Schmitz-Peiffer, C., Craig, D. L., and Biden, T. J. (1999). Ceramide generation is sufficient to account for the inhibition of the insulin-stimulated PKB pathway in C2C12 skeletal muscle cells pretreated with palmitate. J Biol Chem 274, 24202-24210.

Schwaninger, M., Lux, G., Blume, R., Oetjen, E., Hidaka, H., and Knepel, W. (1993). Membrane depolarization and calcium influx induce glucagon gene transcription in pancreatic islet cells through the cyclic AMP-responsive element. J Biol Chem 268, 51685177.

Schwaninger, M., Schofl, C., Blume, R., Rossig, L., and Knepel, W. (1995). Inhibition by antidepressant drugs of cyclic AMP response element-binding protein / cyclic AMP response element-directed gene transcription. Mol Pharmacol 47, 1112-1118.

Sen, P., Mukherjee, S., Ray, D., and Raha, S. (2003). Involvement of the Akt / PKB signaling pathway with disease processes. Mol Cell Biochem 253, 241-246.

Senn, J. J., Klover, P. J., Nowak, I. A., and Mooney, R. A. (2002). Interleukin-6 induces cellular insulin resistance in hepatocytes. Diabetes 51, 3391-3399.

Shaywitz, A. J., and Greenberg, M. E. (1999). CREB: a stimulus-induced transcription factor activated by a diverse array of extracellular signals. Annu Rev Biochem 68, 821861.

Shimabukuro, M., Zhou, Y. T., Levi, M., and Unger, R. H. (1998). Fatty acid-induced beta cell apoptosis: a link between obesity and diabetes. Proc Natl Acad Sci U S A 95, 24982502.

Shimomura, I., Hammer, R. E., Ikemoto, S., Brown, M. S., and Goldstein, J. L. (1999). Leptin reverses insulin resistance and diabetes mellitus in mice with congenital lipodystrophy. Nature 401, 73-76.

Shulman, G. I. (2000). Cellular mechanisms of insulin resistance. J Clin Invest 106, 171176.

Steppan, C. M., and Lazar, M. A. (2002). Resistin and obesity-associated insulin resistance. Trends Endocrinol Metab 13, 18-23.

Storz, P., Doppler, H., Wernig, A., Pfizenmaier, K., and Muller, G. (1999). Cross-talk mechanisms in the development of insulin resistance of skeletal muscle cells palmitate rather than tumour necrosis factor inhibits insulin-dependent protein kinase B (PKB) / Akt stimulation and glucose uptake. Eur J Biochem 266, 17-25.

Strakova, N., Ehrmann, J., Bartos, J., Malikova, J., Dolezel, J., and Kolar, Z. (2005). Peroxisome proliferator-activated receptors (PPAR) agonists affect cell viability, apoptosis and expression of cell cycle related proteins in cell lines of glial brain tumors. Neoplasma $52,126-136$.

Stumvoll, M., and Haring, H. U. (2002). Glitazones: clinical effects and molecular mechanisms. Ann Med 34, 217-224. 
Sun, X. J., Goldberg, J. L., Qiao, L. Y., and Mitchell, J. J. (1999). Insulin-induced insulin receptor substrate-1 degradation is mediated by the proteasome degradation pathway. Diabetes 48, 1359-1364.

Takaki, R., Ono, J., Nakamura, M., Yokogawa, Y., Kumae, S., Hiraoka, T., Yamaguchi, K., Hamaguchi, K., and Uchida, S. (1986). Isolation of glucagon-secreting cell lines by cloning insulinoma cells. In Vitro Cell Dev Biol 22, 120-126.

Tamemoto, H., Kadowaki, T., Tobe, K., Yagi, T., Sakura, H., Hayakawa, T., Terauchi, Y., Ueki, K., Kaburagi, Y., Satoh, S., and et al. (1994). Insulin resistance and growth retardation in mice lacking insulin receptor substrate-1. Nature 372, 182-186.

Thirone, A. C., Huang, C., and Klip, A. (2006). Tissue-specific roles of IRS proteins in insulin signaling and glucose transport. Trends Endocrinol Metab 17, 72-78.

Traxinger, R. R., and Marshall, S. (1989). Recovery of maximal insulin responsiveness and insulin sensitivity after induction of insulin resistance in primary cultured adipocytes. $J$ Biol Chem 264, 8156-8163.

Treadway, J. L., Whittaker, J., and Pessin, J. E. (1989). Regulation of the insulin receptor kinase by hyperinsulinism. J Biol Chem 264, 15136-15143.

Trotti, R., Cestaro, B., Cazzola, R., Ferrari, E., and Rondanelli, M. (2001). Adipose tissue and cytokines. Minerva Gastroenterol Dietol 47, 205-207.

Tzeng, T. F., Liu, I. M., and Cheng, J. T. (2005). Activation of opioid mu-receptors by loperamide to improve interleukin-6-induced inhibition of insulin signals in myoblast $\mathrm{C} 2 \mathrm{C} 12$ cells. Diabetologia 48, 1386-1392.

Unger, R. H. (1981). The milieu interieur and the islets of Langerhans. Diabetologia 20, 111.

Unger, R. H., and Orci, L. (1981). Glucagon and the A cell: physiology and pathophysiology (second of two parts). N Engl J Med 304, 1575-1580.

Usui, I., Imamura, T., Babendure, J. L., Satoh, H., Lu, J. C., Hupfeld, C. J., and Olefsky, J. M. (2005). G protein-coupled receptor kinase 2 mediates endothelin-1-induced insulin resistance via the inhibition of both Galphaq / 11 and insulin receptor substrate-1 pathways in 3T3-L1 adipocytes. Mol Endocrinol 19, 2760-2768.

Usui, I., Imamura, T., Huang, J., Satoh, H., Shenoy, S. K., Lefkowitz, R. J., Hupfeld, C. J., and Olefsky, J. M. (2004). beta-arrestin-1 competitively inhibits insulin-induced ubiquitination and degradation of insulin receptor substrate 1. Mol Cell Biol 24, 8929-8937.

Van Epps-Fung, M., Williford, J., Wells, A., and Hardy, R. W. (1997). Fatty acid-induced insulin resistance in adipocytes. Endocrinology 138, 4338-4345.

Vasudevan, A. R., and Balasubramanyam, A. (2004). Thiazolidinediones: a review of their mechanisms of insulin sensitization, therapeutic potential, clinical efficacy, and tolerability. Diabetes Technol Ther 6, 850-863. 
Virkamaki, A., Ueki, K., and Kahn, C. R. (1999). Protein-protein interaction in insulin signaling and the molecular mechanisms of insulin resistance. J Clin Invest 103, 931-943.

Wang, C., Campos, R. V., Stobie, K. M., Brubaker, P. L., and Drucker, D. J. (1991). Differential glucocorticoid regulation of glucagon gene expression in cell lines derived from rat and hamster islet cell tumors. Cancer Res 51, 1196-1201.

Weir, M. (2001). Impact of immunosuppressive regimes on posttransplant diabetes mellitus. Transplant Proc 33, 23S-26S.

Welsh, N., Cnop, M., Kharroubi, I., Bugliani, M., Lupi, R., Marchetti, P., and Eizirik, D. L. (2005). Is there a role for locally produced interleukin-1 in the deleterious effects of high glucose or the type 2 diabetes milieu to human pancreatic islets? Diabetes 54, 3238-3244.

Whiteman, E. L., Cho, H., and Birnbaum, M. J. (2002). Role of Akt / protein kinase B in metabolism. Trends Endocrinol Metab 13, 444-451.

Whitson, R. H., and Kaplan, S. A. (1985). In vitro recovery of insulin binding after downregulation in cultured normal human monocytes. Am J Physiol 249, E94-98.

Wibo, M., and Poole, B. (1974). Protein degradation in cultured cells. II. The uptake of chloroquine by rat fibroblasts and the inhibition of cellular protein degradation and cathepsin B1. J Cell Biol 63, 430-440.

Withers, D. J., Gutierrez, J. S., Towery, H., Burks, D. J., Ren, J. M., Previs, S., Zhang, Y., Bernal, D., Pons, S., Shulman, G. I., et al. (1998). Disruption of IRS-2 causes type 2 diabetes in mice. Nature 391, 900-904.

Woods, S. C., Lutz, T. A., Geary, N., and Langhans, W. (2006). Pancreatic signals controlling food intake; insulin, glucagon and amylin. Philos Trans $R$ Soc Lond B Biol Sci 361, 1219-1235.

Xu, H. E., Lambert, M. H., Montana, V. G., Parks, D. J., Blanchard, S. G., Brown, P. J., Sternbach, D. D., Lehmann, J. M., Wisely, G. B., Willson, T. M., et al. (1999). Molecular recognition of fatty acids by peroxisome proliferator-activated receptors. Mol Cell 3, 397403.

Yamauchi, T., Kamon, J., Waki, H., Terauchi, Y., Kubota, N., Hara, K., Mori, Y., Ide, T., Murakami, K., Tsuboyama-Kasaoka, N., et al. (2001). The fat-derived hormone adiponectin reverses insulin resistance associated with both lipoatrophy and obesity. Nat Med 7, 941-946.

Yuan, L., Ziegler, R., and Hamann, A. (2002). Chronic hyperinsulinism induced downregulation of insulin post-receptor signaling transduction in Hep G2 cells. J Huazhong Univ Sci Technolog Med Sci 22, 313-316.

Zdychova, J., and Komers, R. (2005). Emerging role of Akt kinase / protein kinase B signaling in pathophysiology of diabetes and its complications. Physiol Res 54, 1-16.

Zick, Y. (2001). Insulin resistance: a phosphorylation-based uncoupling of insulin signaling. Trends Cell Biol 11, 437-441. 
Zick, Y. (2004). Molecular basis of insulin action. Novartis Found Symp 262, 36-50; discussion 50-35, 265-268. 


\section{ACKNOWLEDGEMENTS}

I would like to specially thank Prof. Dr. W. Knepel for giving me the opportunity to develop this fascinating project in his laboratory. I would like to recognize Prof. Knepel's excellent guidance, close supervision and most of all his great patience during my PhD.

I am grateful to Prof. Dr. R. Hardeland and Prof. Dr. D. Doenecke for active scientific discussions, for enriching suggestions and for acting as referent and co-referent of my PhD work.

I am also thankful to Prof. G. Burckhardt for giving me the chance to join the Postgraduate program: "Clinical, Cellular and Molecular Biology of Internal Organs".

Many thanks to Dr. E. Oetjen, Dr. U. Böer and Dr. R. Krätzner for interesting scientific discussions, for invaluable suggestions for the improvement of this $\mathrm{PhD}$ thesis and for computer-related support.

Many thanks to Prof. Dr. M. Opperman, Dr. F. Hüttenrauch and to Dr. rer nat. T. Quentin for their help in the acquisition of experimental expertise required for this PhD work.

Thanks to R. Blume, C. Dickel, D. Krause and I. Cierny for their technical support, for helpful technical discussions and for a kind and caring encouragement.

Thanks to S. Müller for solving most of my administrative problems.

To all my friends in Knepel's lab: Annette, Helena, Svenja, Julia, Anna, Ingrid, Andrei, Marcel, Florian, Silke, Payam, Sanjeev, Christine, Cordula and Anne. Thanks to each and all of you for caring about my work and for always giving me your support! 


\section{Curriculum vitae}

\section{Personal data}

Last names

Name

Date of birth

Place of birth

Nationality

Civil status

\section{School education}

1981-1987

Primary school

1987-1990

Secondary school

1990-1993

High School
González Aguirre

Miranda

15 / 05 / 1975

Mexico City

mexican

married

\section{University education}

1993-1998 University

Chemical Engineering

Metropolitan Autonomous University - Iztapalapa

Mexico City, Mexico

Advisor: Dr. Gretchen Lapidus

Thesis title: Separation of silver from a mineral

material using lixiviation with iron sulfide

1998- $2001 \quad$ Masters

Biochemical Sciences

Biotechnology Institute

National Autonomous University of Mexico

Cuernavaca, Mexico

Advisor: Dr. Tonatiuh Ramírez

Thesis title: Influence of growth parameters variations in the production of rotaviral VP7 and VP4 proteins using the insect cell-baculovirus system

2003-2006 PhD

Georg-August-University Goettingen

Department of Molecular Pharmacology

Goettingen, Germany

Advisor: Prof. Dr. Willhart Knepel

Thesis title: Molecular mechanisms of insulin resistance in glucagon-producing alpha cells 